\title{
Addendum to the Composite Analysis for the E-Area Vaults and Saltstone Disposal Facilities
}

by

J. R. Cook

Westinghouse Savannah River Company

Savannah River Site

Aiken, South Carolina 29808

E. L. Wilhite

L. B. Collard

DOE Contract No. DE-AC09-96SR18500

This paper was prepared in connection with work done under the above contract number with the U.S.

Department of Energy. By acceptance of this paper, the publisher and/or recipient acknowledges the U.S. Government's right to retain a nonexclusive, royalty-free license in and to any copyright covering this paper, along with the right to reproduce and to authorize others to reproduce all or part of the copyrighted paper. 


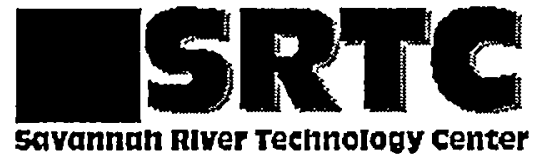

September 21, 1999

WSRC-RP-99-00844-TL

TO: $\quad$ W. T. Goldston, 703-5C

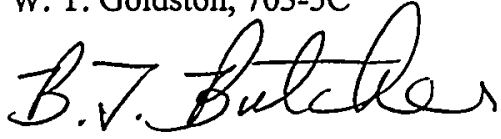

FROM: $\quad$ B. T. Butcher, 773-43A (x5-5810)

\section{TRANSMITTAL OF THE ADDENDUM TO THE COMPOSITE ANALYSIS}

Ref: SRS E-Area and Saltstone Low-Level Waste Disposal Facility Composite Analysis Maintenance Program FY99 Implementation Plan, SWD-SWE-99-012, 2/9/99

Attached is the report entitled, "Addendum to the Composite Analysis for the E-Area Vaults and Saltstone Disposal Facilities", WSRC-RP-99-00844, 9/23/99, prepared by Jim Cook, Elmer Wilhite and Len Collard of SRTC. This report satisfies the commitment in the Composite Analysis (CA) Maintenance Program Plan (reference) to issue a CA Addendum to DOE-SR by 9/23/99. The addendum addresses all the conditions of approval contained in Table 2 of the plan.

Att. (10 copies)

CC: (w/Att)

R. M. Seaborn, 705-3C

P. I. Hudson, 705-3C

M. W. Lewis, 724-7E

H. Holmes, 724-9E

D. F. Sink, 724-15E

L. C. Thomas, 724-7E

J. L. Newman, 703-H

G. T. Jannik, 773-42A

J. R. Fowler, 704-19@N

R. W. Malanowski, 730-2B

W. L. Tamosaitis, 773-A

W. E. Stevens, 773-A

S. M. Serkiz, 773-A

D. I. Kaplan, 773-43A

E. L. Wilhite, 773-43A

J. R. Cook, 773-43A

L. B. Collard, 773-43A

STI, 4 copies, 703-43A

WPT File, 773-43A 


\section{DISCLAIMER}

Portions of this document may be illegible in electronic image products. Images are produced from the best available original document. 
WSRC-RP-99-00844

Revision 0

KEY WORDS: Performance Assessment

Stewardship

Waste Management

\title{
ADDENDUM TO THE COMPOSITE ANALYSIS FOR THE E-AREA VAULTS AND SALTSTONE DISPOSAL FACILITIES
}

\author{
Authors \\ JAMES R. COOK \\ ELMER L. WILHITE \\ LEONARD B. COLLARD \\ Westinghouse Savannah River Company \\ Savannah River Technology Center \\ Aiken, SC 29808
}

September 23, 1999

Westinghouse Savannah River Company

Savannah River Site

Aiken, SC 29808

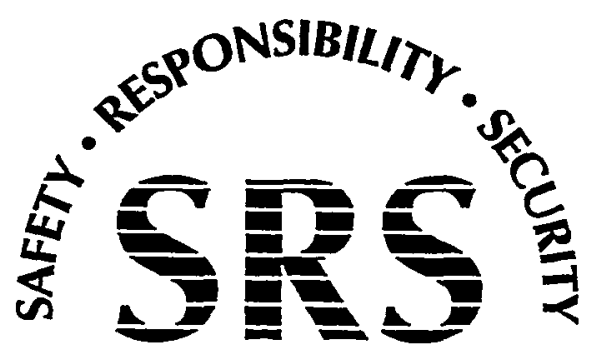

SAVANNAH RIVER SITE 


\section{DISCLAIMER}

This report was prepared as an account of work sponsored by an agency of the United States Government. Neither the United States Government nor any agency thereof, nor any of their employees, makes any warranty, express or implied, or assumes any legal liability or responsibility for the accuracy, completeness, or usefulness of any information, apparatus, product, or process disclosed, or represents that its use would not infringe privately owned rights. Reference herein to any specific commercial product, process, or service by trade name, trademark, manufacturer, or otherwise does not necessarily constitute or imply its endorsement, recommendation, or favoring by the United States Government or any agency thereof. The views and opinions of authors expressed herein do not necessarily state or reflect those of the United States Government or any agency thereof.

This report has been reproduced directly from the best available copy.

Available to DOE and DOE contractors from the Office of Scientific and Technical Information, P.O. Box 62, Oak Ridge, TN 37831; prices available from (615) 576-8401.

Available to the public from the National Technical Information Service, U.S. Department of Commerce; 5285 Port Royal Road, Springfield, VA 22161. 
WSRC-RP-99-00844

Revision 0

KEY WORDS: Performance Assessment

Stewardship

Waste Management

\title{
ADDENDUM TO THE COMPOSITE ANALYSIS FOR THE E-AREA VAULTS AND SALTSTONE DISPOSAL FACILITIES
}

\author{
Authors \\ JAMES R. COOK \\ ELMER L. WILHITE \\ LEONARD B. COLLARD \\ Westinghouse Savannah River Company \\ Savannah River Technology Center \\ Aiken, SC 29808
}

September 23, 1999

Westinghouse Savannah River Company

Savannah River Site

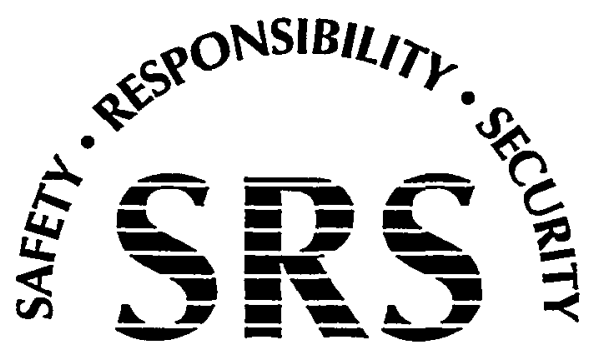

Aiken, SC 29808 
WSRC-RP-99-00844

Revision 0

September 24, 1999

\section{REVIEWS AND APPROVALS}

Authors

Jannes R. Cook, Author

$9 / 22199$

Date

Waste Disposal and Environmental Development

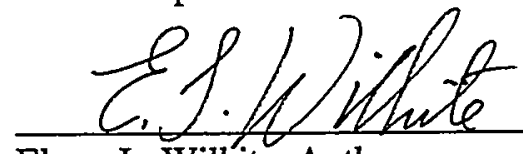

Elmer L. Wilhite, Author

Waste Disposal and Environmental Development

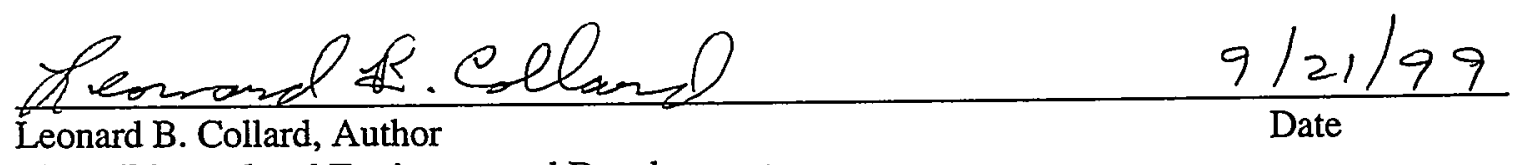

Waste Disposal and Environmental Development

\section{Approvals/Review}

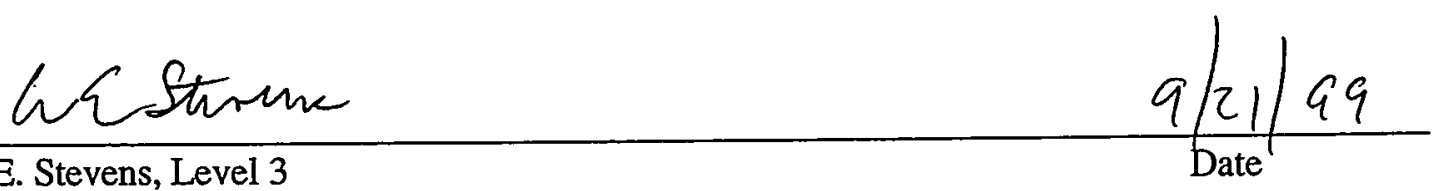

W. E. Stevens, Level 3

Waste Processing Technology/

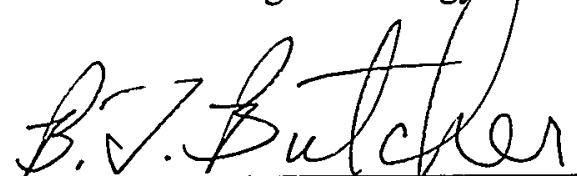

B. T. Butcher, Level 4

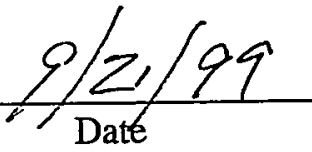

Waste Disposal and Environmental Development

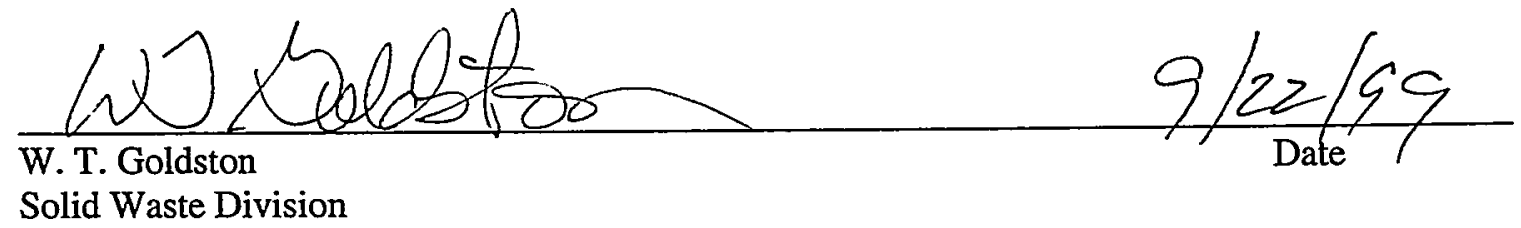




\section{memorandum}

DATE: JAN $21: 1999$

REPLY TO

ATTN OF:

SUBJECT:

TO:

\section{EM-35}

Review of the Savannah River Site Composite Analysis

Assistant Manager for Environmental Management, Savannah River Operations Office Manager, Savannah River Operations Office

The Savannah River Site composite analysis for the E-Area Vaults and Saltstone Disposal Facilities was submitted to the Low-Level Waste Disposal Facilities Federal Review Group (LFRG) for review and approval on November 20, 1997. A review team was convened to conduct a technical review of the composite analysis. The review team prepared its final report for the Savannah River Site composite analysis in June 1998. On July 23-24, 1998, the LFRG met at the Savannah River Site to discuss the results of the review team's final report.

In reviewing the Savannah River Site composite analysis and the review team report, the LFRG considered the purpose of the composite analysis. The composite analysis is a management tool whose purpose is to assist the Department in assessing the possible impacts on the public and environment from multiple sources at a site in order to determine where the Department may need to focus attention or take mitigating actions. Although the LFRG agreed with the review group in its conclusion that the current version of the Savannah River Site composite analysis was lacking from a site-wide perspective, the LFRG also recognized that the primary purpose of this version of the composite analysis was to assist the LFRG in determining if the E-Area Vaults and Saltstone Disposal Facilities could be authorized or if they contributed, in combination with other SRS facilities, to a potential condition that may represent compliance concerns. The LFRG concluded that the composite analysis provided sufficient information to determine that the subject low-level waste sites operation would not contribute significantly to any composite effects. Therefore, if any concerns resulted, management alternatives should be directed at other sites or sources of radioactive contamination. Although the composite analysis was generally adequate (with some additions or corrections) for the LFRG review of the E-Area Vaults and the Saltstone Disposal Facilities, it was not adequate for assessing Site-wide conditions. Therefore, the Savannah River Site composite analysis is approved with conditions per the LFRG recommendation. The following conditions are to be addressed through the maintenance of the composite analysis:

1. Point of Assessment/Pathways - Based on the approved Land Use Plan and as a first step in a more comprehensive analysis, issue an addendum to the composite analysis to reflect a single point of compliance at the confluence of Upper Three Runs with the Savannah River using the recreational scenario currently in the composite analysis. 
2. Uncertainty and Sensitivity Analysis - Perform a sensitivity analysis on the radionuclides important to the composite analysis and flux rates and on the hydrologic model including the groundwater divide and the model boundary conditions. Perform an Uncertainty Analysis on the inventory, flux rates, and resultant dose calculations for the radionuclides important to the composite analysis.

3. Source Term/Inventory - Provide a complete source term for the composite analysis to include a complete inventory of the Upper Three Runs watershed and a reanalysis of the source term that was arbitrarily assigned to $\mathrm{Cs}$ and $\mathrm{Sr}$ to provide a more realistic radionuclide distribution.

4. Include in the addendum to the composite analysis the assumptions and justification for the assumptions used in the analysis.

A Disposal Authorization Statement will be issued for the Savannah River Site disposal facilities upon the receipt and acceptance of a satisfactory schedule for the composite analysis maintenance plan. Please provide this schedule within 45 days from the date of this letter. The schedule for the composite analysis maintenance plan should include the time frame for completing the following items:

- Disposition of all composite analysis review team comments (see attached enclosure Appendix G \& H Review comments from Composite Analysis).

- Discussion of the environmental monitoring program, inclusion of environmental monitoring data, and comparison with the expected results from the composite analysis.

- Inclusion of the information that Savannah River Site committed to be incorporated in the composite analysis maintenance plan over the course of the composite analysis review.

If your staff have any questions regarding this action, they should contact Jay Rhoderick (301-903-7211) or Bill Murphie (301-903-7216), co-chairs of the LFRG.

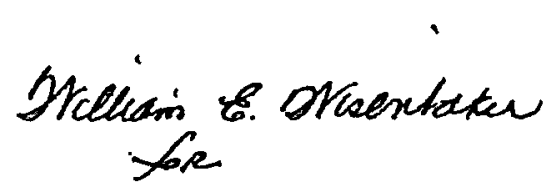

James Fiore

Acting Deputy Assistant Secretary

for Environmental Restoration

Environmental Management

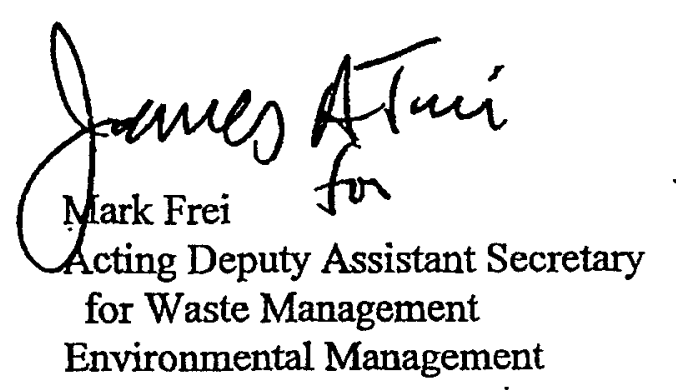

Environmental Management 


\section{CONTENTS}

INTRODUCTION

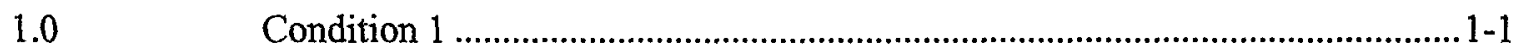

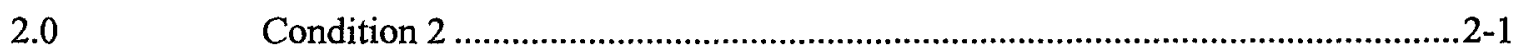

2.1 Sensitivity Analysis - Radionuclides.................................................2-1

2.2 Sensitivity Analysis - Hydrologic Model..........................................2-1

2.2.1 Impact of Remediation Activities on the Groundwater Divide Between Fourmile Branch and Upper Three Runs within the

General Separations Area

2.2.2 Bounding Estimate of all General Separations Area Contaminants Migrating to Either of the Streams ......................................................2-1

2.2.3 Model Boundary Conditions............................................................2-6

2.2.4 Uncertainty Analysis............................................................2-10

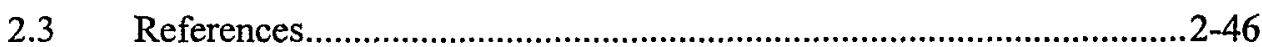

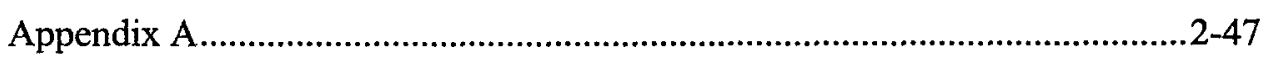

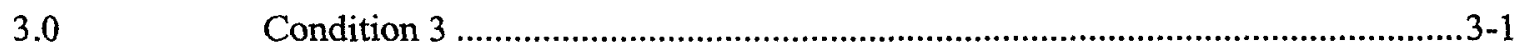

3.1 Complete Inventory of Upper Three Runs Watershed ......................... 3-1

3.2 Reanalysis of the Source Term that was Arbitrarily Assigned

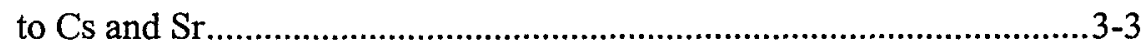

3.3 References..................................................................................

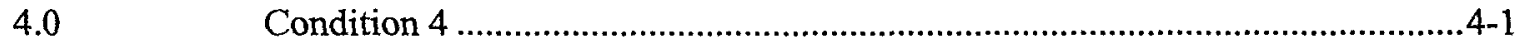

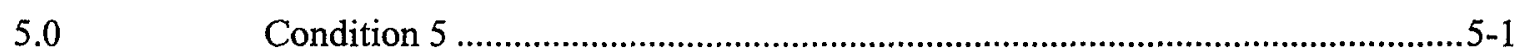

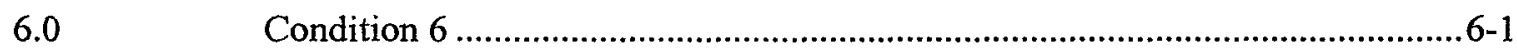

6.1 Comparison with Environmental Monitoring Program.........................6-1

6.1.1 Environmental Monitoring Program.................................................6-1

6.1.2 Effluent Monitoring ......................................................................6-1

6.1.3 Environmental Surveillance.........................................................6-1

6.1.4 Radiological Releases...................................................................6-1

6.1.5 Radiological Surveillance...........................................................6-1

6.2 Comparison of Environmental Monitoring Data with Composite Analysis Results..........................................................................6-2

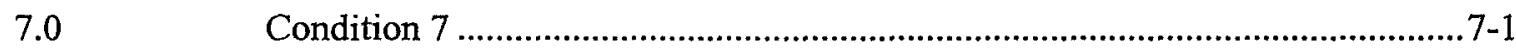

Attachment 1 Maintenance Program for the E-Area Vaults and Saltstone Performance Assessments, and the Composite Analysis ..................................................A1-1

Attachment 2 Savannah River Site Future Use Plan .........................................................A2-1 
THIS PAGE INTENTIONALLY LEFT BLANK 


\section{INTRODUCTION}

In September 1997, the Composite Analysis (CA) for the E-Area Vaults and Saltstone Disposal Facilities (WSRC-RP-97-311, Rev. 0) was issued per USDOE 5820.2A and associated guidance. Subsequently, the U.S. Department of Energy (USDOE) Low-Level Waste Disposal Facilities Federal Review Group (LFRG) conducted a review of the CA. On January 21, 1999, USDOE approved the CA with several conditions (J. Fiore and M. Frei Memorandum to Assistant Manager for Environmental Management, Savannah River Operations Office, Review of the Savannah River Site Composite Analysis, 1/21/99). The approval memorandum follows this introduction.

This addendum to the CA has been prepared to respond to each of the conditions of approval. Each of the conditions is stated in italicized text below with the response following. The first four conditions are numbered as in the approval memorandum, the last three were unnumbered in the approval memorandum but have been numbered here for ease of reference.

Per the SRS PA/CA maintenance plan (SWD-SWE-99-0057, MAINTENANCE PROGRAM FOR THE E-AREA VAULTS AND SALTSTONE PERFORMANCE ASSESSMENTS, AND THE COMPOSITE ANALYSIS, FYOO IMPLEMENTATION PLAN), Attachment 1, the information contained in this addendum will be incorporated into the next revision of the Composite Analysis. 
THIS PAGE INTENTIONALLY LEFT BLANK 


\subsection{Condition 1}

Point of Assessment/Pathways - Based on the approved Land Use Plan and as a first step in a more comprehensive analysis, issue an addendum to the composite analysis to reflect a single point of compliance at the confluence of Upper Three Runs with the Savannah River using the recreational scenario currently in the composite analysis.

Following are pertinent sections of the Savannah River Site (SRS) CA, which have been revised in response to the condition stated above. Section numbering, headings, table and figure numbers, and references refer to the original CA document (WSRC-RP-97-311, Rev. 0). The complete source term for the Tims Branch watershed, developed in response to Condition 3, has been incorporated in these revised sections.

\subsection{SUMMARY AND CONCLUSIONS}

This report documents the CA performed on the two active SRS low-level radioactive waste (LLW) disposal facilities. The facilities are the Z-Area Saltstone Disposal Facility and the E-Area Vaults (EAV) Disposal Facility. The analysis calculated potential releases to the environment from all sources of residual radioactive material expected to remain in the General Separations Area (GSA). The GSA is the central part of the SRS and contains all of the waste disposal facilities, the chemical separation facilities and associated high-level waste storage facilities as well as numerous other sources of radioactive material. The analysis considered 114 potential sources of radioactive material containing 115 radionuclides.

As shown in Table 1-1, the calculated maximum dose to a hypothetical future member of the public is $1.8 \mathrm{mrem} / \mathrm{year}$ at the mouth of UTR, the point of maximum exposure to which the public may have access, based on the approved Future Use Plan (Attachment 2). This dose is well below the U.S. Department of Energy (USDOE) primary dose limit of $100 \mathrm{mrem} / \mathrm{year}$ and the dose constraint of $30 \mathrm{mrem} / \mathrm{year}$. The calculated maximum collective dose to a hypothetical future population is 0.045 person-rem/year. The radionuclides contributing the majority of the dose are ${ }^{3} \mathrm{H},{ }^{14} \mathrm{C},{ }^{237} \mathrm{~Np}$, and isotopes of uranium. A former LLW disposal facility, the Mixed Waste Management Facility (MWMF) is the major source of these isotopes. Based on the low calculated doses, a quantitative As Low As Reasonably Achievable (ALARA) analysis of disposal options was not deemed necessary in this iteration of the CA.

The results of the CA clearly indicate that continued disposal of low-level waste in the Saltstone and EAV facilities, consistent with their respective radiological performance assessments, will have no adverse impact on future members of the public.

\subsubsection{Points of Assessment}

The point of assessment for the $\mathrm{CA}$ is the geographic location that hypothetical future members of the public (both individuals and populations) can reasonably be expected to access, taking into consideration any natural barriers and land use planning for the SRS and vicinity. Two media could be contaminated by radionuclides contained in facilities located in the GSA: groundwater and surface water that is recharged by groundwater. Contamination of the ground surface is not expected and thus air and soil are not routes of potential contaminant transport. A more in-depth discussion of transport pathways is provided in Section 4.3. 
Table 1-1 Composite Analysis Results - Upper Three Runs at Savannah River

\begin{tabular}{|c|c|c|c|c|c|c|c|c|c|}
\hline Radionuclide & $\begin{array}{l}\text { Time of } \\
\text { Peak } \\
\text { Dose } \\
\text { (years) }\end{array}$ & $\begin{array}{c}\text { Fish } \\
\text { Ingestion } \\
\text { Dose } \\
\text { (mrem/yr) }\end{array}$ & $\begin{array}{c}\text { Shore-line } \\
\text { Dose } \\
\text { (mrem/yr) }\end{array}$ & $\begin{array}{l}\text { Swimming } \\
\text { Dose } \\
\text { (mrem/yr) }\end{array}$ & $\begin{array}{l}\text { Boating } \\
\text { Dose } \\
\text { (mrem/yr) }\end{array}$ & $\begin{array}{c}\text { Total } \\
\text { Recreational } \\
\text { Fishing Dose } \\
\text { (mrem/yr) }\end{array}$ & $\begin{array}{c}\text { Water } \\
\text { Ingestion } \\
\text { Dose }^{2} \\
(\mathrm{mrem} / \mathrm{yr})\end{array}$ & $\begin{array}{l}\text { All Pathways } \\
\text { Dose }^{3} \\
\text { (mrem/yr) }\end{array}$ & $\begin{array}{c}\text { Collective } \\
\text { Dose }^{4} \\
\text { (person-rem/yr) }\end{array}$ \\
\hline${ }^{3} \mathrm{H}$ & 62 & $5.9 \times 10^{-02}$ & 0.0 & $1.1 \times 10^{-3}$ & 0.0 & $6.0 \times 10^{-2}$ & 1.2 & 1.3 & $3.2 \times 10^{-02}$ \\
\hline${ }^{14} \mathrm{C}$ & 728 & 1.8 & 0.0 & 0.0 & 0.0 & 1.8 & $7.4 \times 10^{-03}$ & 1.8 & $4.5 \times 10^{-02}$ \\
\hline${ }^{237} \mathrm{~Np}$ & 685 & $2.2 \times 10^{-02}$ & $5.2 \times 10^{-05}$ & $8.2 \times 10^{-09}$ & $9.6 \times 10^{-09}$ & $2.2 \times 10^{-02}$ & $4.3 \times 10^{-02}$ & $6.5 \times 10^{-02}$ & $1.6 \times 10^{-03}$ \\
\hline${ }^{233} \mathrm{U}^{2}$ & 545 & $3.0 \times 10^{-04}$ & $7.7 \times 10^{-07}$ & $8.1 \times 10^{-11}$ & $9.6 \times 10^{-11}$ & $3.0 \times 10^{-04}$ & $2.9 \times 10^{-03}$ & $3.2 \times 10^{-03}$ & $8.0 \times 10^{-05}$ \\
\hline${ }^{234} \mathrm{U}$ & 383 & $6.9 \times 10^{-03}$ & $3.1 \times 10^{-05}$ & $1.3 \times 10^{-09}$ & $1.6 \times 10^{-09}$ & $6.9 \times 10^{-03}$ & $6.8 \times 10^{-02}$ & $7.5 \times 10^{-02}$ & $1.9 \times 10^{-03}$ \\
\hline${ }^{235} \mathrm{U}$ & 548 & $2.4 \times 10^{-04}$ & $2.4 \times 10^{-04}$ & $4.5 \times 10^{-08}$ & $5.3 \times 10^{-08}$ & $4.8 \times 10^{-04}$ & $2.4 \times 10^{-03}$ & $2.9 \times 10^{-03}$ & $7.2 \times 10^{-05}$ \\
\hline${ }^{236} \mathrm{U}$ & 549 & $9.6 \times 10^{-04}$ & $3.9 \times 10^{-06}$ & $1.5 \times 10^{-10}$ & $1.8 \times 10^{-10}$ & $9.6 \times 10^{-04}$ & $9.4 \times 10^{-03}$ & $1.0 \times 10^{-02}$ & $2.5 \times 10^{-04}$ \\
\hline${ }^{238} \mathrm{U}$ & 551 & $6.5 \times 10^{-03}$ & $2.6 \times 10^{-05}$ & $9.7 \times 10^{-10}$ & $1.1 \times 10^{-09}$ & $6.5 \times 10^{-03}$ & $6.3 \times 10^{-02}$ & $7.0 \times 10^{-02}$ & $1.8 \times 10^{-03}$ \\
\hline
\end{tabular}

Notes:

The recreational fishing scenario, which includes fish ingestion, shoreline exposure, and boating, is used to estimate the maximum dose to a hypothetical individual.

2 The water ingestion dose, assuming consumption of one liter of untreated Upper Three Runs water per day, was computed to estimate collective dose to a hypothetical population.

3 To estimate population dose, it was assumed that each person in the hypothetical population would be exposed per the recreational fishing scenario and the drinking water scenario.

4 The hypothetical population is assumed to consist of 25 adult persons. 
UTR and Fourmile Branch (FMB) form the northern and southern boundaries of the GSA (Figure 2.3-2). Both of these streams remain on site until they reach the Savannah River. Both of the streams cut into the uppermost aquifer subject to contamination from the GSA (Section 2.3.5). UTR also cuts into the Gordon aquifer, which is the lowermost of the two aquifers subject to contamination from the GSA. FMB is upgradient with respect to the GSA for the Gordon aquifer. The Gordon aquifer flows northwestward under FMB towards UTR. Thus, these streams will intercept all plumes of groundwater contamination emanating from the GSA. The SRS Future Use Plan (Attachment 2) indicates that release of the site to the public for unrestricted use will not occur over the time period of this analysis; therefore, on-site use by the public of potentially-contaminated groundwater is not a reasonable expectation.

Contaminated surface water is considered a potential source of exposure to a hypothetical future member of the public in this analysis. All contaminated groundwater will discharge to streams that bound the GSA. Water infiltrating the disposal facilities under consideration, Saltstone and the EAV, will discharge to UTR. While land-use plans are expected to restrict use of the SRS during the time period of the analysis, the confluence of on-site streams with the Savannah River poses a potential means of public access to contaminated environmental media. Thus, the point of assessment for this analysis is the mouth of UTR at the Savannah River.

Even though land-use planning envisions the continual control of the SRS, consistent with current boundaries, it is conceivable that a member of the public could gain access to the mouth of UTR by boat from the Savannah River. Thus, the mouth of UTR, at the furthest downstream point where stream water remains undiluted with Savannah River water, is the point for the assessment of potential dose to a hypothetical future member of the public.

For the assessment of potential collective dose to future populations, this analysis conservatively assumed that a population of 25 individuals received their drinking water $(1 \mathrm{~L}$ per day per person) from the mouth of UTR. This population was also assumed to take part in activities defined for the maximally exposed individual (i.e., recreational fishing).

\subsection{Comparison With Dose Limits and Constraints}

The peak dose to a maximally exposed individual within the performance time period of 1000 years is estimated to be approximately $1.8 \mathrm{mrem} / \mathrm{yr}$ at the mouth of UTR. This estimated dose is well below the primary dose limit of $100 \mathrm{mrem} / \mathrm{year}$ established by USDOE Order 5400.5 (Section 2.4.3).

In the CA Guidance document, an additional dose constraint of $30 \mathrm{mrem} / \mathrm{year}$ is used "to ensure that no single source, practice, or pathway uses an extraordinary portion of the primary dose limit." The estimated dose in this CA is also below this constraint. Thus an options analysis is not required.

\subsection{Principal Sources Contributing to Dose}

The major radionuclides contributing to dose in the Composite Analysis are ${ }^{14} \mathrm{C},{ }^{3} \mathrm{H},{ }^{237} \mathrm{~Np}$, and isotopes of uranium (Section 5.5). The predominant source of these radionuclides is the MWMF, as indicated in Table 4.4-5.

The active low-level waste disposal facilities addressed in the CA, the EAV and the Saltstone facilities, are relatively insignificant sources of these radionuclides. The saltstone wasteform and the naval reactor components disposed in the EAV resist leaching and the vaults control 
infiltration of water into the wastes. These barriers to leaching reduce and delay the release of radionuclides to the subsurface environment. Predicted releases from these facilities during the first 1000 years after disposal are therefore negligible and the doses attributable to these facilities during this time period are insignificant relative to the total dose calculated for the CA.

\subsection{Effects of Sensitivities}

The sensitivity analysis (Section 6) shows that the results of the CA are most sensitive to the selection of the point of assessment. The point of assessment was derived from the SRS Future Use Plan (Attachment 2) which projects no unrestricted use of any of the current SRS lands. Near the GSA, the dose to the hypothetical maximally exposed member of the public would only be $2.4 \mathrm{mrem} /$ year. Given the conservatism of the current analysis, potential doses to members of the public, even on UTR, are unlikely to exceed the dose constraint.

\subsection{ALARA Considerations}

The maximum peak dose of $1.8 \mathrm{mrem} / \mathrm{yr}$ calculated for the GSA in this analysis is considerably lower than the dose limit (100 mrem/yr) and dose constraint $(30 \mathrm{mrem} / \mathrm{yr})$. Thus, a quantitative ALARA analysis of options for reducing future doses may not be warranted. Such an assessment analyzes the cost-benefit of dose reduction; however, if the estimated cost of the analysis alone is likely to exceed the monetary equivalent of reducing the dose to zero, then the assessment is not warranted.

To determine whether a quantitative ALARA analysis is warranted, a monetary equivalence of potential dose reduction must be assigned. The USDOE recommends an equivalence in the range from $\$ 1,000$ to $\$ 10,000$ per person-rem reduced. Thus, calculation of population doses associated with the GSA was required to make this determination.

\subsubsection{Population Doses}

The population dose calculated for the ALARA process in this CA conservatively assumes that a hypothetical population of 25 adult individuals is exposed to water at the mouth of UTR. These persons are assumed to obtain their drinking water ( $1 \mathrm{~L}$ per day) from UTR. They are also assumed to carry out the activities in the recreational fishing scenario used for the maximally exposed individual.

Population doses were calculated using the LADTAP XL spreadsheet model (Hamby 1991a), described in Sections 5.4 and 5.5. The peak dose to the hypothetical population was 0.045 person-rem/yr.

\subsubsection{ALARA Analysis}

An ALARA analysis calculates the cost of actions that could be taken to reduce population dose versus the benefit of the dose reduction. However, when maximum individual doses are calculated to be below the $30 \mathrm{mrem} / \mathrm{yr}$ dose constraint in a CA, the question becomes whether the cost of a quantitative ALARA analysis is justified.

In this CA of the GSA, the maximum individual dose was calculated to be $1.8 \mathrm{mrem} / \mathrm{yr}$ for all radionuclides: well below the $30 \mathrm{mrem} / \mathrm{yr}$ dose constraint. To evaluate whether an ALARA analysis is warranted, population doses were also calculated. The maximum population dose was calculated to be approximately 0.045 person-rem/yr. Using the USDOE's estimate of monetary 
equivalence for dose reduction of between $\$ 1,000$ to $\$ 10,000$ per person-rem potentially avoided, a maximum cost of dose reduction of $\$ 450$ is calculated. This maximum cost is calculated assuming dose is reduced to zero, at an upper-end cost of $\$ 10,000$ per person-rem and assuming a dose integration time of one year. The many conservative assumptions that went into estimation of population dose further maximizes this cost. The cost of the present analysis of the base case exceeds this maximum cost, and thus the cost of evaluating the impact of more than one option for the GSA is expected to greatly exceed the maximum cost. Based on this information, an ALARA analysis is not warranted because of the low population dose potentially associated with the presence of subsurface radionuclides in the GSA.

The conclusion that an ALARA analysis is not warranted is strongly influenced by the selection of the time over which population dose is integrated. USDOE guidance on the dose integration time has not been issued. Due to the conservative assumptions used in this CA, a one-year integration time was selected.

\subsection{Options Analysis}

The calculated dose to the hypothetical maximally exposed member of the public of $1.8 \mathrm{mrem} / \mathrm{yr}$ is below the dose constraint of $30 \mathrm{mrem} / \mathrm{yr}$. Thus, per USDOE guidance, an options analysis is not required. 


\subsection{Condition 2}

Uncertainty and Sensitivity Analysis - Perform a sensitivity analysis on the radionuclides important to the composite analysis and flux rates and on the hydrologic model including the groundwater divide and the model boundary conditions. Perform an uncertainty analysis on the inventory, flux rates, and resultant dose calculations for the radionuclides important to the composite analysis.

\subsection{Sensitivity Analysis - Radionuclides}

The sensitivity analysis on the radionuclides important to the CA and flux rates is integral to the uncertainty analysis, which is presented at the end of this section, and is not reproduced here.

\subsection{Sensitivity Analysis - Hydrologic Model}

The additional sensitivity analysis on the hydrologic model focused on the groundwater divide (i.e., impact of remediation activities, bounding estimates of dose resulting from all radionuclides migrating to either stream) and the model boundary conditions. Each of the investigations is presented below.

\subsubsection{Impact of Remediation Activities on the Groundwater Divide Between Fourmile Branch} and Upper Three Runs within the General Separations Area

The groundwater divide between FMB and UTR within the "upper" aquifer zone (water table) based on groundwater flow simulations (Flach and Harris, 1997) is depicted in Figure 2.2-1. The shaded arrows in Figure 2.2-1 are constant in length, and therefore only show groundwater flow direction in the horizontal plane. The divide can be affected by large-scale remediation activities that alter surface recharge or involve groundwater pumping. Candidates include the interim surface cap for the Old Burial Ground (OBG) applied in 1997, and pump-treat-reinject (PTR) operations for the F- and H-Area seepage basins scheduled for 1998. Changes to groundwater flow following the OBG cap and long-term F- and H-Area PTR operation were simulated by Flach (1998). The modeling results described in Flach (1998) can be used to investigate impacts to the groundwater divide. Figure 2.2-2 shows predicted steady-state groundwater flow directions after the three large-scale remediation operations have been in place for several years. The heavy solid line shows the groundwater divide before remediation activities, and the heavy dotted line depicts the divide after long-term remediation. Groundwater injection in F-and H-Area is seen to move the divide toward FMB, whereas the decreased surface recharge over the OBG moves the divide away from FMB towards UTR. Figures 2.2-3 and 2.2-4 are the same as Figures 2.2-1 and 2.2-2 respectively, except that vectors proportional to the rate of groundwater flow are shown. These figures better illustrate three-dimensional aspects of the overall groundwater flow field. Near the groundwater divide, there is a strong downward flow component. Near groundwater discharge areas, the lateral flow components dominate.

\subsubsection{Bounding Estimate of All General Separations Area Contaminants Migrating to Either of the Streams}

The sensitivity of results calculated in the SRS CA to the location of the groundwater divide was discussed qualitatively in Section 6.4 of the CA. Following is a more quantitative analysis. 
Groundwater flow directions in Upper Three Runs aquifer unit, "upper" zone

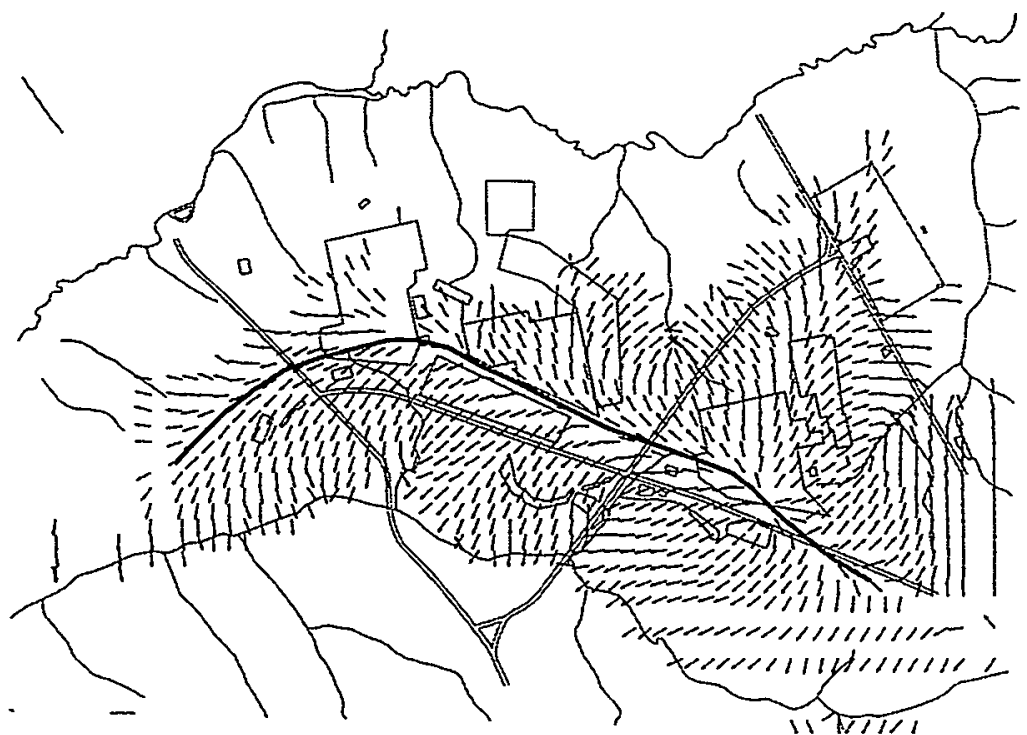

Figure 2.2-1 Simulated Groundwater Divide Before OBG Cap and F- and H-Area PTR Systems; Flow Direction Illustrated by Constant Length Vectors

Groundwater flow directions in Upper Three Runs aquifer unit, "upper" zone

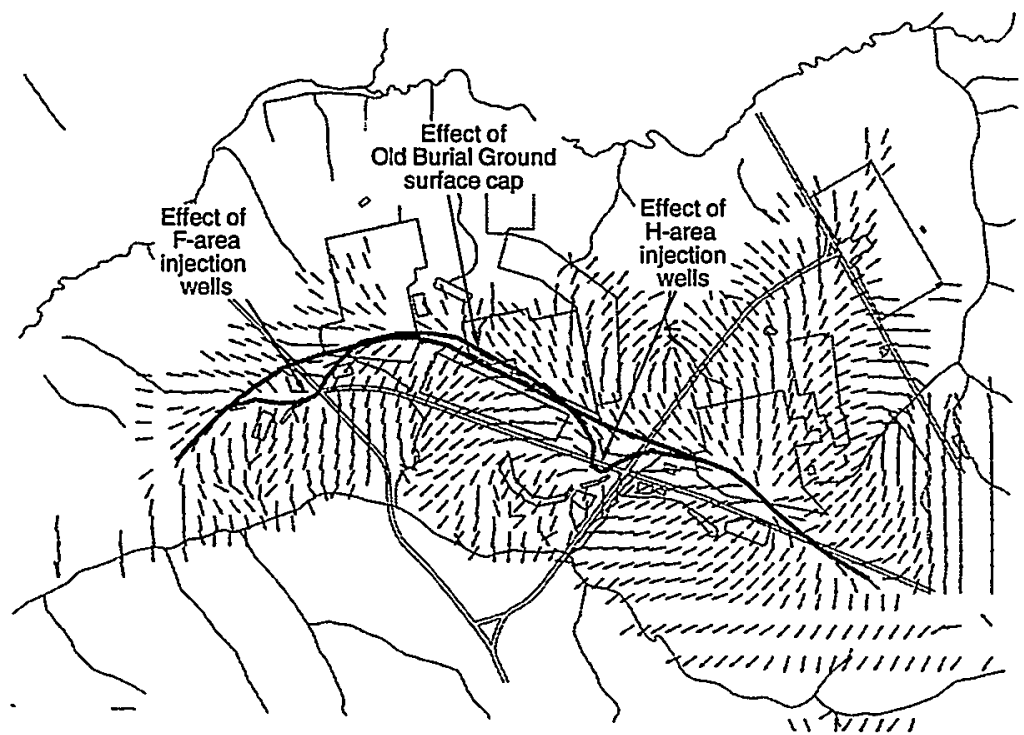

Figure 2.2-2 Simulated Groundwater Divide After OBG Cap and F- and H-Area PTR Systems; Flow Direction Mlustrated by Constant Length Vectors 
Groundwater flow directions in Upper Three Runs aquifer unit, "upper" zone

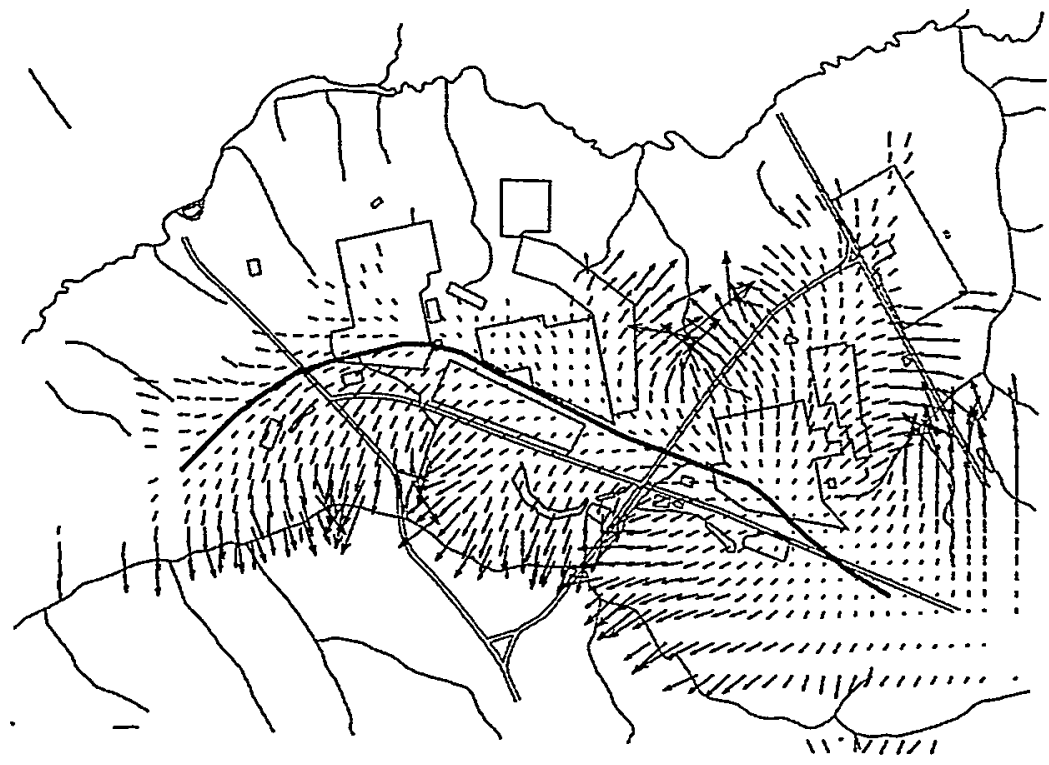

Figure 2.2-3 Simulated Groundwater Divide Before OBG Cap and F- and H-Area PTR Systems; Flow Direction Illustrated by Proportional Length Vectors

Groundwater flow directions in Upper Three Runs aquifer unit, "upper" zone

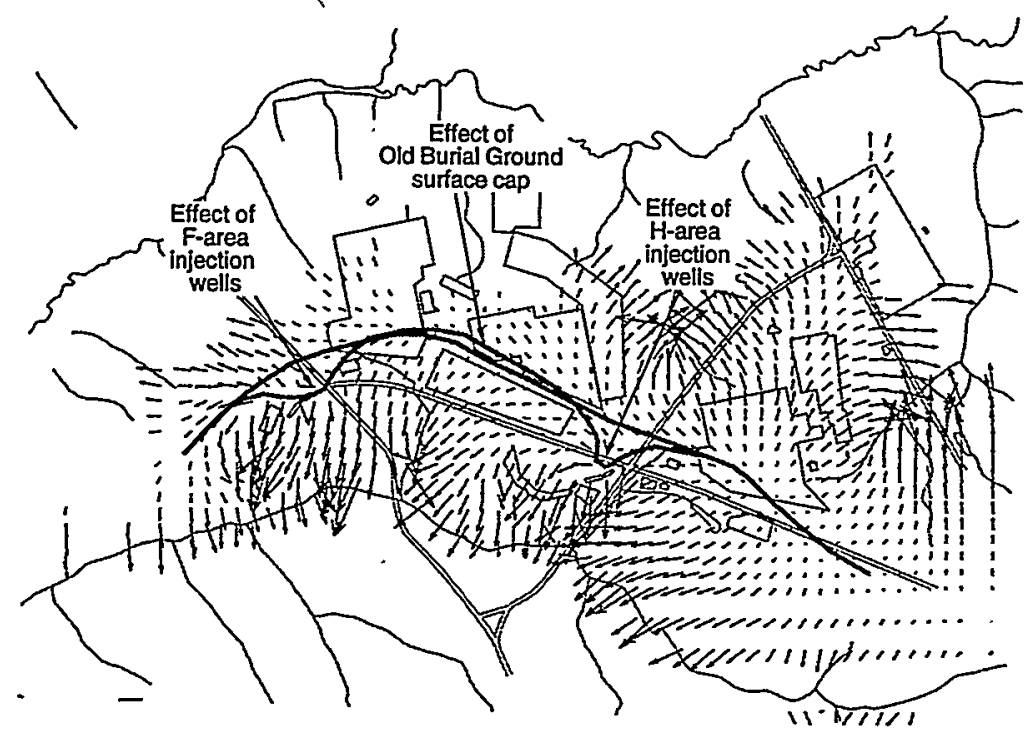

Figure 2.2-4 Simulated Groundwater Divide After OBG Cap and F- and H-Area PTR Systems; Flow Direction Mlustrated by Proportional Length Vectors 
In the $\mathrm{CA}$, the present location of the groundwater divide, which lies between the MWMF and the $O B G$, was assumed to be constant for the entire period of analysis. To illustrate the sensitivity of the analysis results to the location of the divide, doses were estimated assuming that all contaminants released within the GSA would migrate to either of the two surface streams, UTR and FMB.

Doses in the CA are calculated from the concentration of radionuclides in the streams. Radionuclide concentrations are calculated from the flux of radionuclides to one of the streams and the average volumetric flow of the streams. The calculated peak fluxes to the streams are presented in Table 5.3-1 of the CA. Calculated doses at the stream mouths are presented in Table 5.5-2; doses calculated at the GSA are presented in Table 6.1-1.

The doses resulting from the assumption that all radionuclides would migrate to only one of the streams were calculated by ratio of the $\mathrm{CA}$ dose to the $\mathrm{CA}$ flux to one stream multiplied by the sum of the CA fluxes to each stream. This method over estimates the total flux to a given stream because it does not take into account the longer flow path from the disposal area to one of the streams that was used in the original CA calculation (e.g., tritium flux calculated in the CA to FMB will be attributed to UTR). This effect will be most pronounced for tritium because of its short half-life.

For example, the tritium dose due to drinking water from UTR at the GSA, assuming all of the sources migrate to UTR, was calculated according to the following equation:

Dose $_{\text {UTR+FMB }}=$ Flux UTR+FMB $_{\text {UT }} *$ Dose $_{\text {UTR }} /$ Flux UTR $_{\text {UTR }}$

where Dose UTR+FMB is the dose calculated from all sources,

Flux UTR+FMB is the sum of the fluxes to each of the streams from Table 5.3-1,

Dose UTR is the dose due to tritium from only those sources that drain to UTR from Table 6.1-1, and

Flux uTR is the flux of tritium to UTR from only those sources that drain to UTR from Table 5.3-1

Dose $_{\text {UTR+FMB }}=\left(1.05 \times 10^{4}+6.34 \times 10^{3}\right) * 2.4 / 1.05 \times 10^{4}$

Dose $_{U T R+F M B}=3.85 \mathrm{mrem} /$ year

Estimated doses from the significant radionuclides are presented in Table 2.2-1.

Dose calculated from drinking water at the GSA should be compared with values presented in Table 6.1-1. Doses calculated from the recreation scenario at the stream mouths should be compared with values presented for all pathways in Table 5.5-2. The increase in calculated dose is greatest for FMB due to the lower flow rate $(24 \mathrm{cfs})$ compared with that in UTR $(217 \mathrm{cfs})$.

Although the dose calculated for drinking water from FMB in this sensitivity analysis is large, 64 $\mathrm{mrem} / \mathrm{year}$, it is incredible that this dose would ever be realized. First, as discussed in the accompanying analysis of the factors affecting the location of the groundwater divide, the migration of all contaminants to only one stream is not credible. Second, the large dose calculated is due to tritium. As stated above, no correction was made for the decay that would take place due to the longer flow path if this scenario were to happen. Third, the dose due to tritium occurs very quickly (in Table 5.5-2 of the CA, the peak dose from tritium occurs at 62 years in UTR and 61 years in FMB). For the dose to be realized, the scenario of someone 
Table 2.2-1 Estimated Doses from Significant Radionuclides

\begin{tabular}{|c|c|c|c|c|}
\hline Radionuclide & $\begin{array}{c}\text { Estimated Dose } \\
\text { From Drinking } \\
\text { UTR } \\
\text { Water at GSA } \\
\text { (mrem/year) }\end{array}$ & $\begin{array}{c}\text { Estimated Dose } \\
\text { From Drinking } \\
\text { FMB } \\
\text { Water at GSA } \\
\text { (mrem/year) }\end{array}$ & $\begin{array}{l}\text { Estimated Dose } \\
\text { from } \\
\text { Recreation Scenario } \\
\text { at UTR Mouth, } \\
\text { (mrem/year) }\end{array}$ & $\begin{array}{l}\text { Estimated Dose from } \\
\text { Recreation Scenario } \\
\text { at FMB Mouth } \\
\text { (mrem/year) }\end{array}$ \\
\hline${ }^{3} \mathrm{H}$ & 3.85 & $6.37 \times 10^{1}$ & $9.62 \times 10^{-02}$ & $8.50 \times 10^{-01}$ \\
\hline${ }^{14} \mathrm{C}$ & $2.73 \times 10^{-02}$ & $3.99 \times 10^{-01}$ & 3.28 & $2.88 \times 10^{1}$ \\
\hline${ }^{237} \mathrm{~Np}$ & $3.84 \times 10^{-01}$ & 5.95 & $9.71 \times 10^{-02}$ & $9.05 \times 10^{-01}$ \\
\hline${ }^{234} U$ & $2.05 \times 10^{-01}$ & 3.27 & $1.09 \times 10^{-02}$ & $9.81 \times 10^{-02}$ \\
\hline${ }^{235} \mathrm{U}$ & $9.26 \times 10^{-03}$ & $1.51 \times 10^{-01}$ & $9.67 \times 10^{-04}$ & $8.74 \times 10^{-03}$ \\
\hline${ }^{236} \mathrm{U}$ & $3.82 \times 10^{-02}$ & $6.24 \times 10^{-01}$ & $2.04 \times 10^{-03}$ & $1.87 \times 10^{-02}$ \\
\hline${ }^{238} \mathrm{U}$ & $2.33 \times 10^{-01}$ & 3.71 & $1.26 \times 10^{-02}$ & $1.15 \times 10^{-01}$ \\
\hline
\end{tabular}


obtaining drinking water from FMB within 62 years would have to occur. This is incredible because of the land use planning discussed in the $\mathrm{CA}$ and because waste management and environmental remediation activities at SRS will continue for several more decades.

\subsubsection{Model Boundary Conditions}

Figure 2.2-5 is a hand-drawn (not produced by computer), large-scale, potentiometric map of the Gordon aquifer that incorporates well and stream water level data with a conceptual understanding of groundwater flow (Hiergesell, 1999). The map includes the updip continuation of the Gordon aquifer as the Steed Pond aquifer north of UTR. The Gordon aquifer is recharged from the overlying UTR aquifer, and by lateral flow into the domain across the east and south boundaries of GSA. The Gordon aquifer is discharged by UTR along the north boundary of the GSA and lateral outflow along the west boundary. Relative to recharge and lateral flows, net groundwater flow through the underlying Meyers Branch confining system is small. Simulated groundwater flow in the Gordon aquifer (CA Figure 5.1-20) agrees with Figure 2.2-5 and (CA Figure 5.1-14) which are based on measured water levels.

The no-flow boundary terminology used in discussions with the Review Team is confusing and has been subsequently clarified in WSRC-TR-96-0399, Rev. 1. The Gordon aquifer is assumed to completely discharge to UTR from both sides of the stream, because the stream bed and recent alluvium deeply incise the aquifer. Therefore, groundwater does not flow beneath UTR from one side to the other. UTR functions as a groundwater flow divide for the Gordon aquifer, and is a no-flow boundary in this sense.

Figure 2.2-6 schematically illustrates how model boundary conditions are defined along no-flow boundaries, such as UTR. As groundwater flow approaches the groundwater divide created by a stream, the flow turns upward and discharges to ground surface at seepage faces comprising the stream bed and/or adjoining wetland areas. This physical situation is reproduced in the model by assigning a drain boundary condition to the uppermost nodal layer and a no-flow boundary condition to underlying nodes, as shown in Figure 2.2-6. Therefore, no-flow boundaries actually consist of both drain and no-flow boundary conditions.

Figure 2.2-7 is a hand-drawn (not produced by computer), large-scale, potentiometric map of the water table that incorporates well and stream water level data with a conceptual understanding of groundwater flow (Hiergesell, 1998). In the GSA, the water table resides in the UTR aquifer. Alluvial deposits along FMB deeply incise the "lower" aquifer zone of UTR aquifer. FMB is assumed to completely drain the UTR aquifer from each side, such that FMB functions as a groundwater divide as shown in Figure 2.2-7. Drain boundary conditions are specified along FMB for surface nodes while no-flow conditions are prescribed for underlying nodes. Simulated flow agrees with Figure 2.2-7 and CA Figure 5.1-13, which are based on measured water and stream levels.

The no-flow boundary between McQueen Branch and FMB can be better justified by referring to Figure 2.2-7, which shows the water table over a larger area than Figure 5.1-13. As shown in Figure 2.2-7, the eastern, no-flow, boundary of the flow model crosses potentiometric lines at nearly right angles. Although there is probably some inward flux across this boundary, the head gradients are very small and can be neglected. Note that the simulated water table (CA Figure 5.1-11) agrees well with Figure 2.2-7, including along the eastern boundary. 


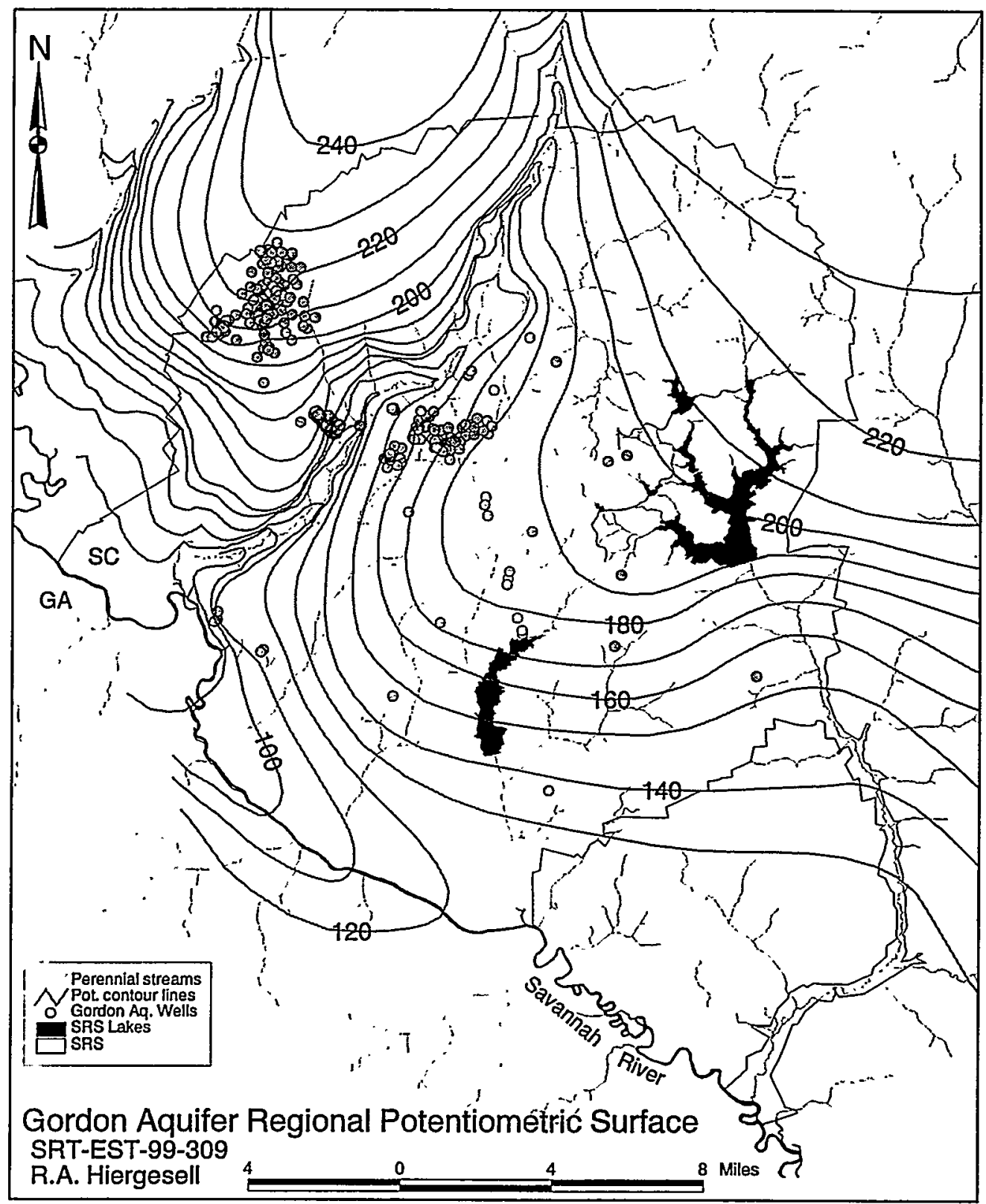

Figure 2.2-5 Gordon Aquifer Regional Potentiometric Surface

Rev. 0 


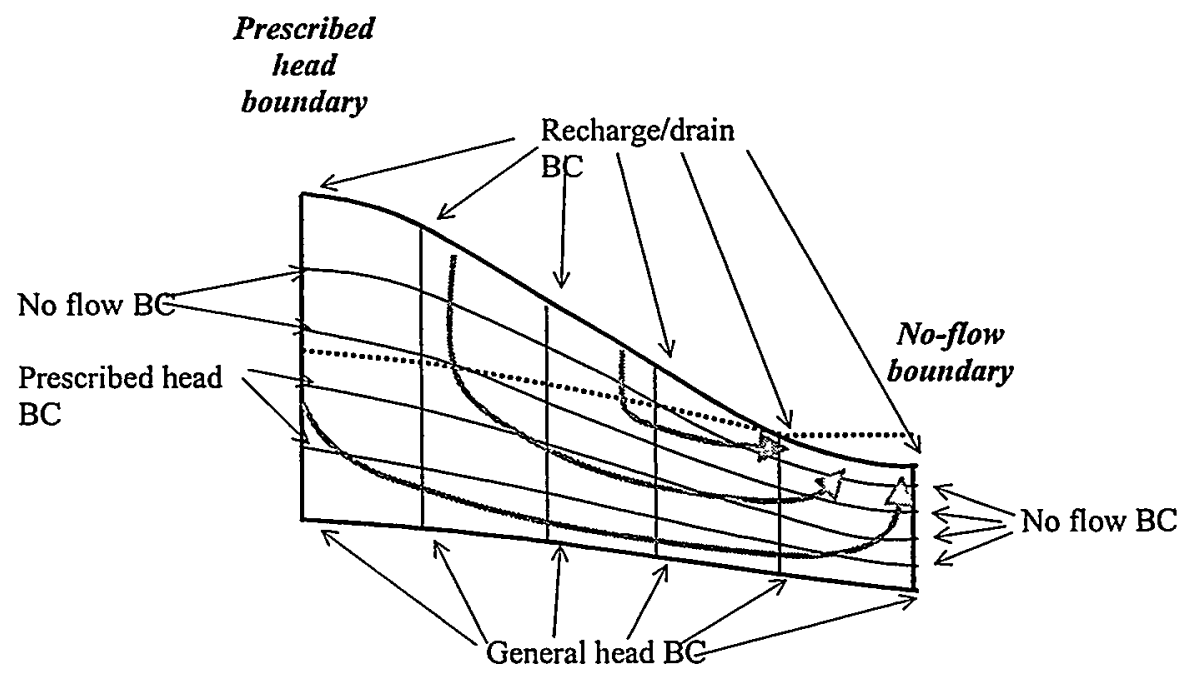

Figure 2.2-6 Schematic Diagram of No-flow and Prescribed Head Boundary Condition Specification 


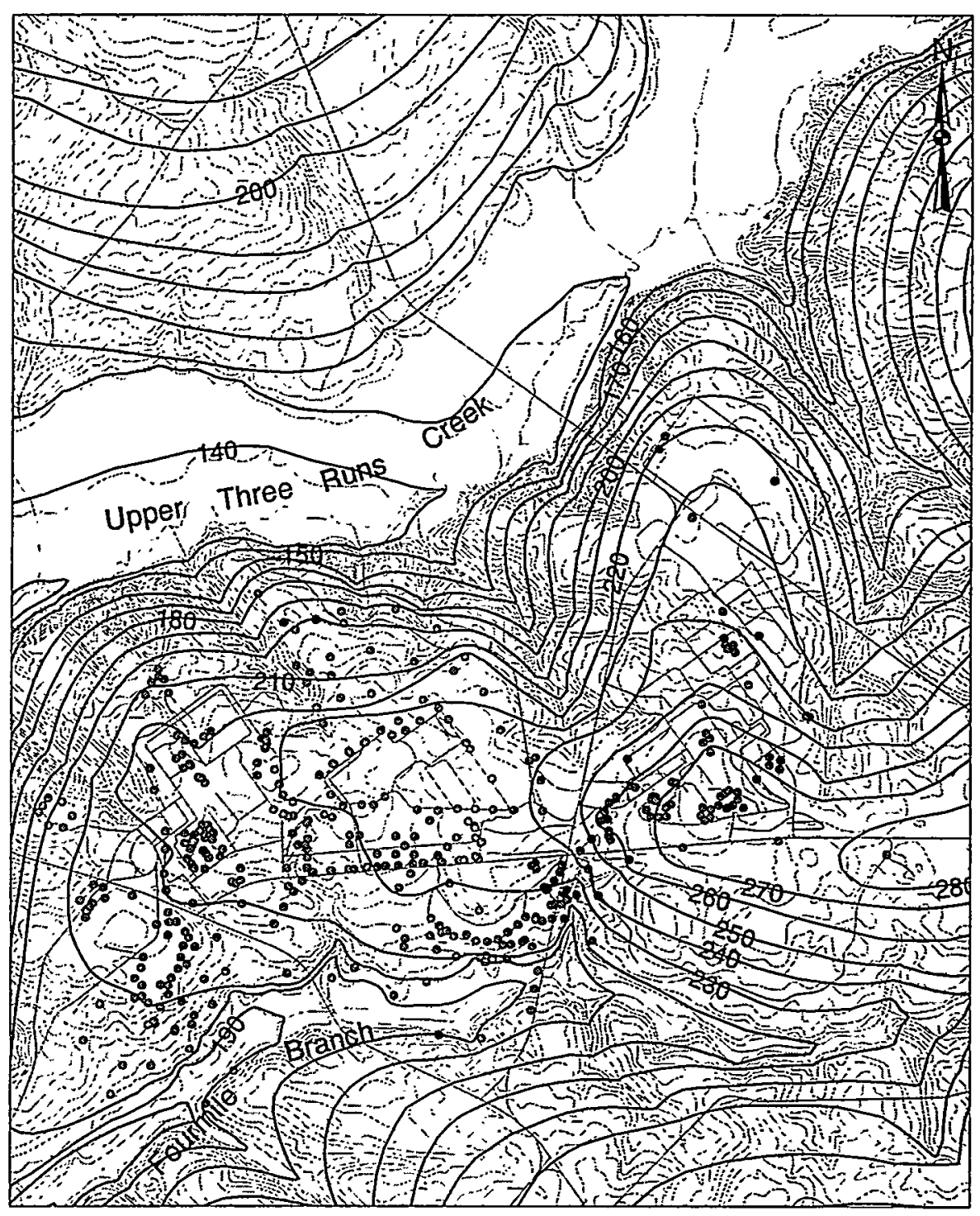

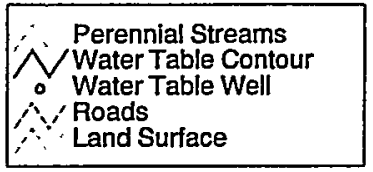

General Separatios Area Water Table Elevation WSRC-TR-98-00045

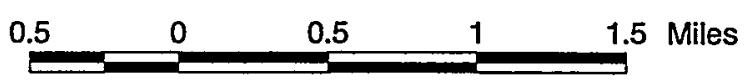

15

Figure 2.2-7 General Separations Area Water Table Elevation 


\subsubsection{Uncertainty Analysis}

As part of the response to Condition 2, the following uncertainty analysis on the inventory, flux rates, and resultant dose calculations for the radionuclides important to the $\mathrm{CA}$ was performed. It is presented as Section 6.6 of the CA.

\subsection{Uncertainty Analysis on Inventory}

An uncertainty analysis on inventory was conducted for radionuclides important to the CA. Two general screening processes were employed to determine the most important radionuclides and their significant sources. First, dose results were screened to determine the most important radionuclides at each stream. Second, inventories and contaminant fluxes to the water table were screened to identify the significant sources of the most important radionuclides.

After screening was completed, sampling from probability density functions (PDFs) resulted in inventory variations at significant sources. The first realization set of inventory variations was generated by combining the first sample inventory from each source. Repeating this process of combining the nth sample inventory from each source generated one thousand realization sets. Each set of inventory variations was used to generate variations in contaminant fluxes to the water table, fluxes to streams, and hypothetical doses at the streams. Peak doses from each inventory variation were plotted and compared with the base case peak dose.

\subsubsection{Dose Screening to Determine Important Radionuclides and Associated Streams}

The radionuclides most important to the CA were determined by comparing doses (from Table 5.5-2) with a threshold value of one percent of the $30 \mathrm{mrem} / \mathrm{yr}$ dose constraint (i.e., 0.30 $\mathrm{mrem} / \mathrm{yr}$ ) established for SRS (see Section 2.4.3). This step indicated that three radionuclides, as shown in Table 6.6-1, are important. All three contaminants are important at FMB, but only ${ }^{14} \mathrm{C}$ is important at UTR.

\subsubsection{Inventory and Water Table Flux Screening to Determine Significant Sources}

A two-step screening process determined the significant radionuclide sources of the important radionuclides. First, facilities with relatively low inventories were eliminated from further consideration. Second, facilities with relatively low contaminant fluxes to the water table were eliminated.

\section{$\underline{\text { Inventory Screening }}$}

Tritium inventories at all facilities listed in Table 4.4-2 are plotted in Figure 6.6-1. The highest inventory is MWMF with an order of magnitude of $1 \times 10^{6} \mathrm{Ci}$. The threshold was set four orders of magnitude below this level at $1 \times 10^{2} \mathrm{Ci}$. All facilities with inventories below $1 \times 10^{2} \mathrm{Ci}$ were screened out except for $\mathrm{F}$ Canyon, which was retained because its $68 \mathrm{Ci}$ inventory was only slightly below the threshold.

Sources represented by clear bars in Figure 6.6-1 were eliminated during the inventory-screening phase. Sources with crosshatched bars were retained during the first screening phase. Based on flux to water table curves shown in Figures 5.2-3 through 5.2-22, elimination of sources with crosshatched bars was expected during the second screening phase. Sources with solid bars were 
Table 6.6-1 Radionuclides Exceeding Threshold Dose of 0.3 mrem/yr

\begin{tabular}{|l|l|l|}
\hline Radionuclide & Dose $(\mathrm{mrem} / \mathrm{yr})^{1}$ & Stream \\
\hline${ }^{3} \mathrm{H}$ & 0.32 & FMB \\
${ }^{14} \mathrm{C}$ & 13.00 & FMB \\
${ }^{14} \mathrm{C}$ & 1.80 & UTR \\
${ }^{237} \mathrm{~Np}$ & 0.70 & FMB \\
\hline
\end{tabular}

Notes:

' From Table 5.5-2

Rev. 0 


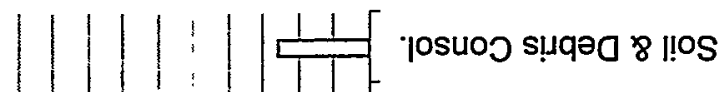

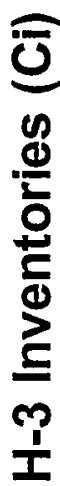


retained during the first screening phase and their elimination was not expected during subsequent screening. Bar attributes for subsequent inventory figures are identical to the bar attributes for Figure 6.6-1.

${ }^{14} \mathrm{C}$ inventories at all facilities listed in Table 4.4-2 are plotted in Figure 6.6-2. The highest inventory is OBG with an order of magnitude of $1 \times 10^{3} \mathrm{Ci}$. The threshold was set three orders of magnitude below this level at $1 \mathrm{Ci}$. All facilities with inventories below $1 \times 10 \mathrm{Ci}$ were screened out.

${ }^{237} \mathrm{~Np}$ inventories at all facilities listed in Table 4.4-2 are plotted in Figure 6.6-3. The highest inventory, $12 \mathrm{Ci}$, is found in $235-\mathrm{F}$, the Plutonium Fabrication Facility. The threshold was set five orders of magnitude below this level at $1 \times 10^{-4} \mathrm{Ci}$. All facilities with inventories below $1 \times 10^{-4} \mathrm{Ci}$ were screened out.

${ }^{237} \mathrm{~Np}$ is a part of a decay chain that includes ${ }^{241} \mathrm{Pu}$ and ${ }^{241} \mathrm{Am}$. Inventories for ${ }^{241} \mathrm{Pu}$ and ${ }^{241} \mathrm{Am}$ are included in Figures 6.6-4 and 6.6-5, respectively. These two figures were used only to add to the list of ${ }^{237} \mathrm{~Np}$ facilities to consider in subsequent screening and analysis. The subsequent screening for ${ }^{241} \mathrm{Pu}$ and ${ }^{241} \mathrm{Am}$ was based on the flux of ${ }^{237} \mathrm{~Np}$ to the water table.

In Figure 6.6-4 the highest inventory for ${ }^{241} \mathrm{Pu}$ is $\mathrm{OBG}$ with an order of magnitude of $1 \times 10^{4} \mathrm{Ci}$. The threshold was set four orders of magnitude below this level at $1 \mathrm{Ci}$. The list of facilities with inventories above $1 \mathrm{Ci}$ was compared with the list of retained ${ }^{237} \mathrm{~Np}$ inventory facilities. Facilities added to the ${ }^{237} \mathrm{~Np}$ inventory list were as follows:

- Naval Reactors

- 772-F Laboratory

- Tanks 17-20

- Tanks 25-28.

In Figure 6.6-5, the highest inventory for ${ }^{241} \mathrm{Am}$ is Tanks 21-24 with an order of magnitude of $1 \times 10^{2} \mathrm{Ci}$. The threshold was set four orders of magnitude below this level at $1 \times 10^{-2} \mathrm{Ci}$. The list of facilities with inventories above $1 \times 10^{-2} \mathrm{Ci}$ was compared with the list of retained ${ }^{237} \mathrm{~Np}$ inventory facilities. Facilities added to the ${ }^{237} \mathrm{~Np}$ inventory list were as follows:

- Naval Reactors (already added due to ${ }^{241} \mathrm{Pu}$ inventory)

- E-Area Trenches

- Soil and Debris Consolidation Facility

- Tanks $17-20$ (already added due to ${ }^{241}$ Pu inventory)

- Tanks $25-28$ (already added due to ${ }^{241} \mathrm{Pu}$ inventory)

- H Process Sewer

- H Seepage Basin.

\section{Contaminant Flux to the Water Table Screening}

For the second screening step for significant sources, contaminant fluxes to the water table were examined. Each source with a peak flux less than .001 of the maximum peak flux of all sources (shown in bold in the Peak Flux tables below) was eliminated from future consideration. 
$\forall$
8
8
0
2
$\vdots$
1
2
0
0
0
0
3

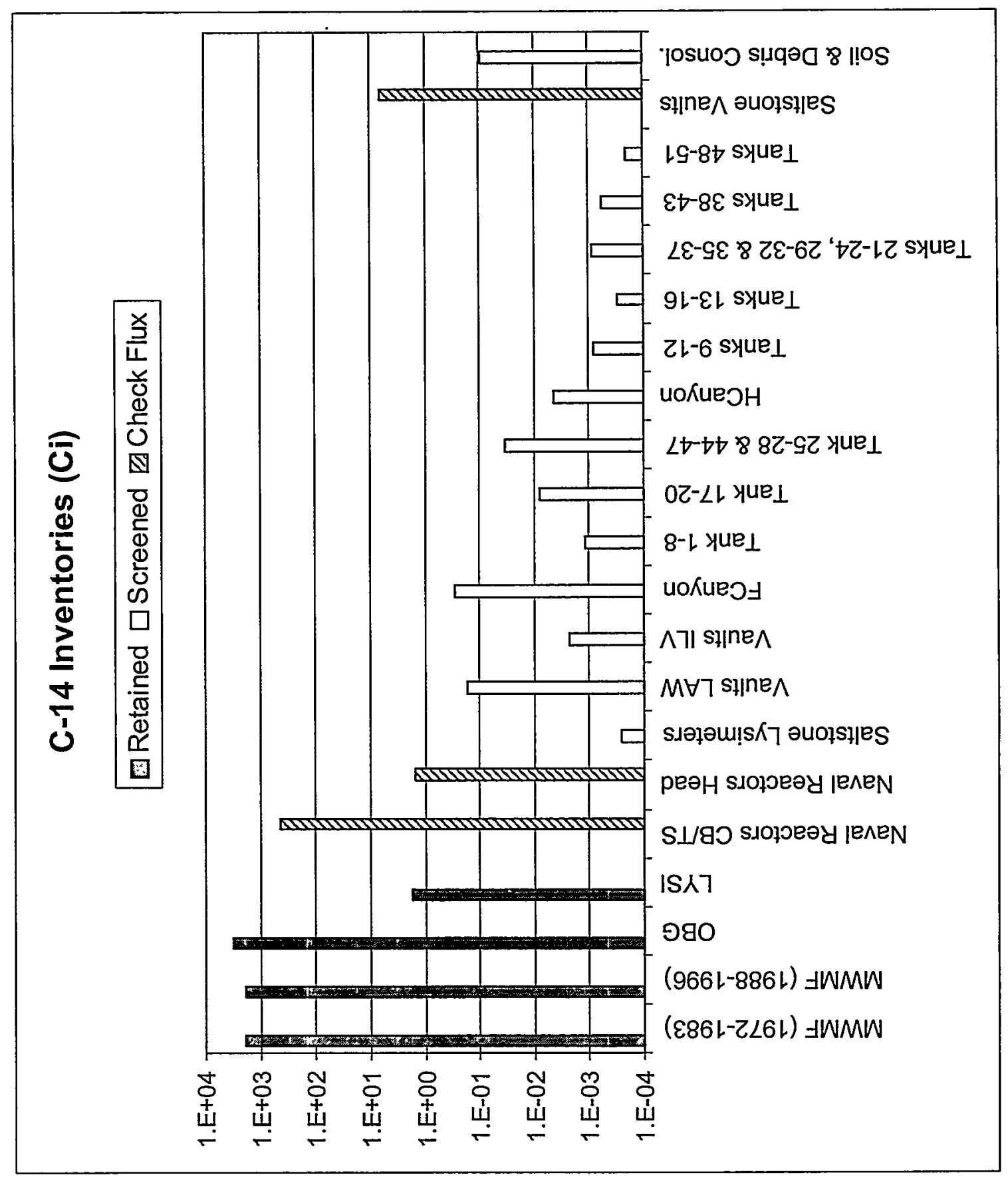

0
$\vdots$
0
4



ฏ. 


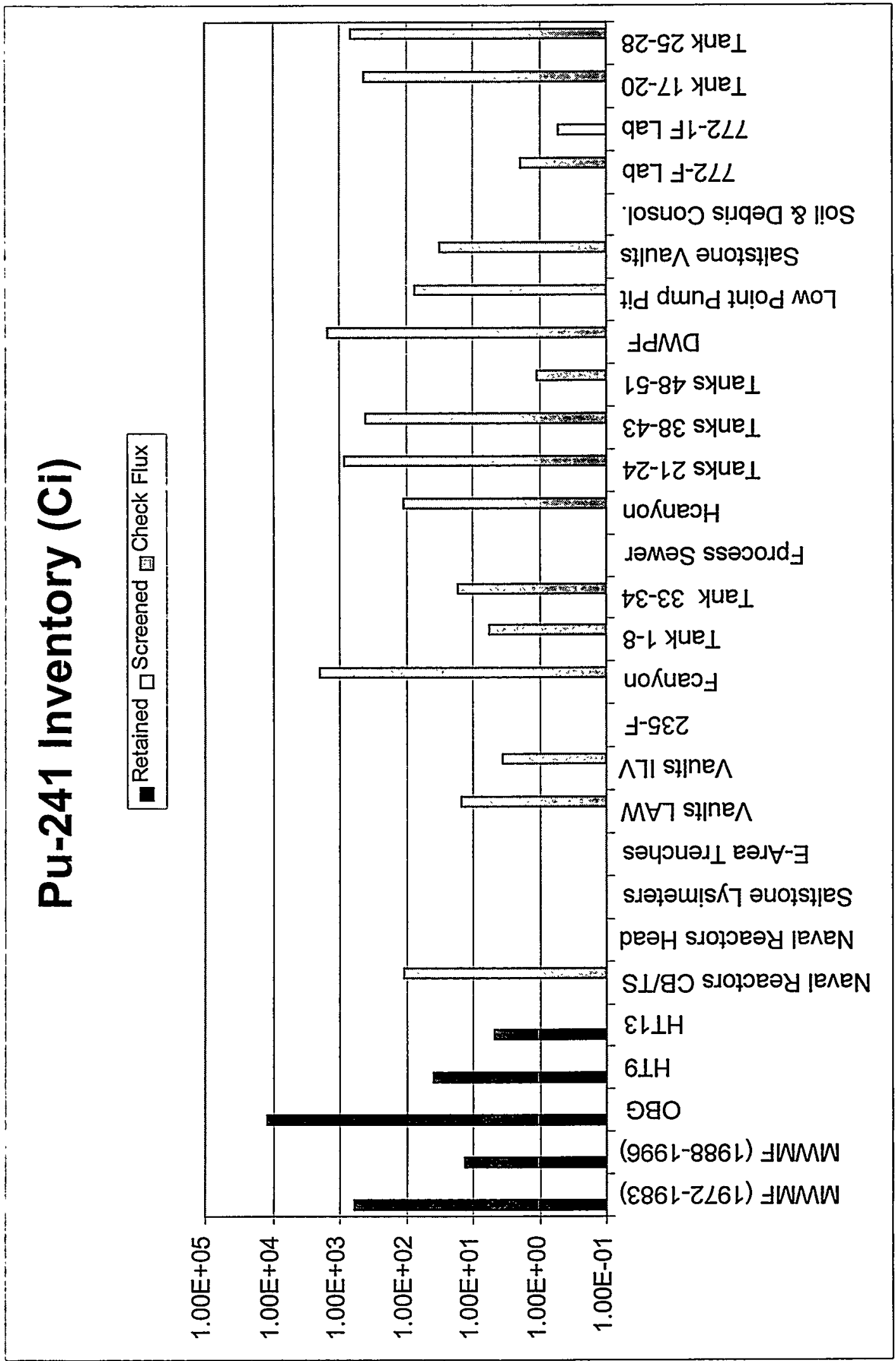

文

ลू 


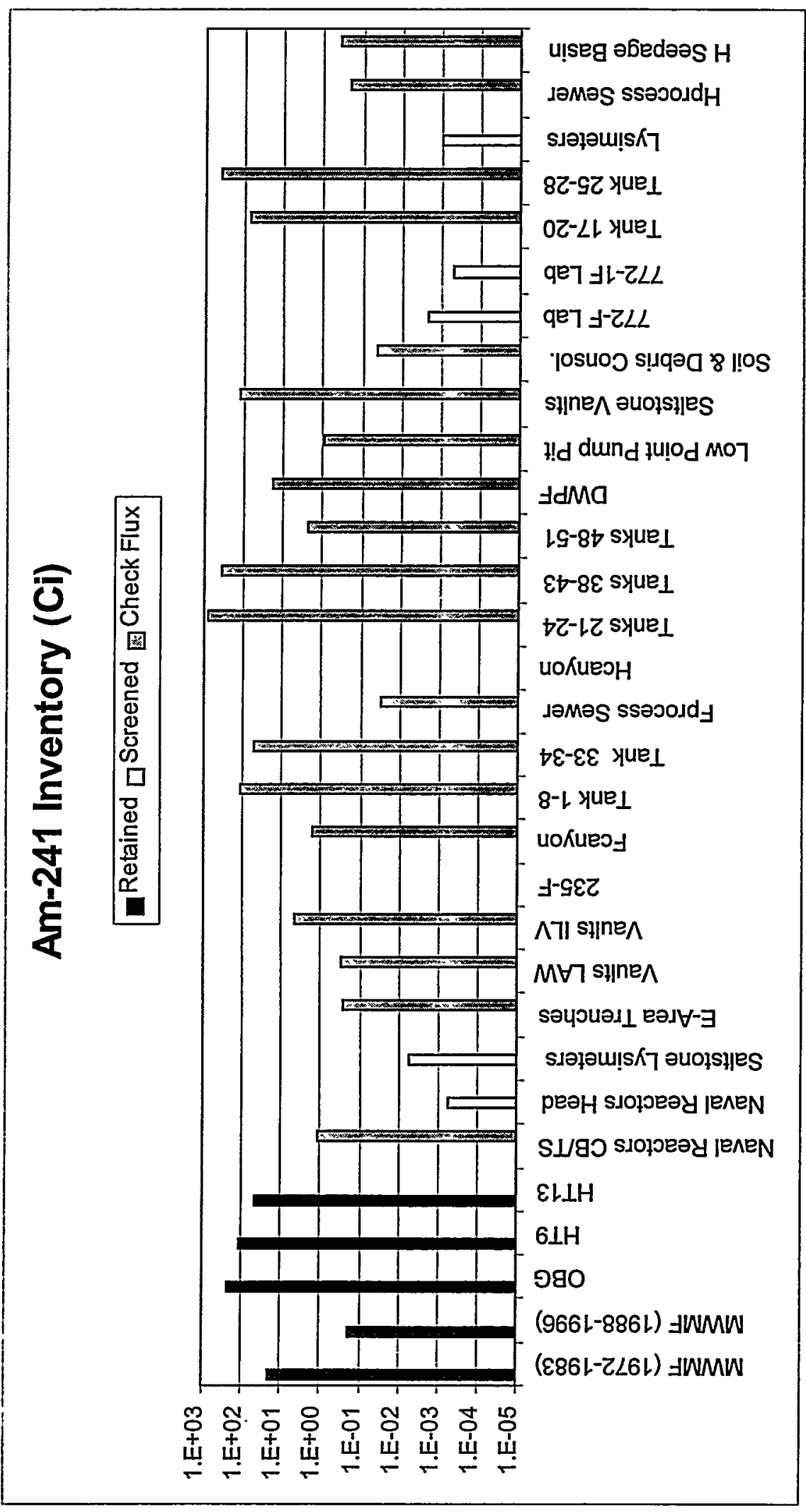

过

命 
Fluxes to the water table derived from Table 4.4-5 are listed and plotted in the following tables and figures:

$\begin{array}{lll}\text { Contaminant } & \text { Listed } & \text { Plotted } \\ {^{3} \mathrm{H}} } & \text { Table 6.6-2 } & \text { Figure 6.6-6 } \\ { }^{14} \mathrm{C} & \text { Table 6.6-3 } & \text { Figure 6.6-7 } \\ { }^{237} \mathrm{~Np} & \text { Table 6.6-4 } & \text { Figure 6.6-8 }\end{array}$

In Tables 6.6-2 through 6.6-4, sources are grouped as to whether they were eliminated during the inventory-screening phase, eliminated during the contaminant flux screening phase, or survived both screening phases. Table 6.6-4 contains the inventories of ${ }^{237} \mathrm{~Np}$ parent products for those facilities that were added to the list for future consideration based on their ${ }^{241} \mathrm{Am}$ or ${ }^{241} \mathrm{Pu}$ inventories.

Figures 6.6-6 through 6.6-8 only show the sources that passed the inventory screen. In these figures, sources with dark bars survived the water table contaminant flux screen, while sources without shading were eliminated.

\section{$\underline{\text { Screening Summary }}$}

Screening based on flux at the water table produced two unexpected sources for retention. The 235-F and $\mathrm{H}$ Canyon facilities for ${ }^{237} \mathrm{~Np}$ were the two exceptions. The $235-\mathrm{F}$ facility had the highest ${ }^{237} \mathrm{~Np}$ inventory by almost an order of magnitude leading to its retention. H Canyon had the third highest inventory, but it was retained only after slightly relaxing the screening criteria from $3.2 \times 10^{-5} \mathrm{Ci} / \mathrm{yr}$ (based on .001 of HT13's $3.2 \times 10^{-2} \mathrm{Ci} / \mathrm{yr}$ flux) to $1.0 \times 10^{-5} \mathrm{Ci} / \mathrm{yr}$.

All sources that were retained after screening are shown in Table 6.6-5 with the applicable contaminant. Table 6.6-5 also contains the data qualifier for the site that indicates the level of certainty associated with the information, with a lower value indicating more certainty.

\subsubsection{Inventory Variation at Significant Sources}

\section{$\underline{\text { Approach }}$}

To examine uncertainty based on the inventory, typically a random sample is selected from an inventory probability density function (PDF). A sample is selected for each source's inventory and the samples are combined to form a realization set. That realization set feeds two computer models. The first model simulates transport of contaminants through the vadose zone, while the second model simulates transport of contaminants through the aquifer, producing a concentration and dose at each stream. Inventory sampling continues until each realization set has been selected and modeled, generating a set of doses at each stream. The set of doses forms the basis for determining the dose probabilities.

PDFs were developed for the twelve significant sources at eight locations, as presented in Table 6.6-5. The data qualifier provided a means to describe the inventory uncertainty. For data qualifiers 1 and 2, a lognormal PDF was assumed. For the rest of the sources, a logtriangular PDF was assumed. The base case inventory was used as the median value for each PDF. As the data qualifier increased, the uncertainty increased and the PDF's range of inventories increased. 


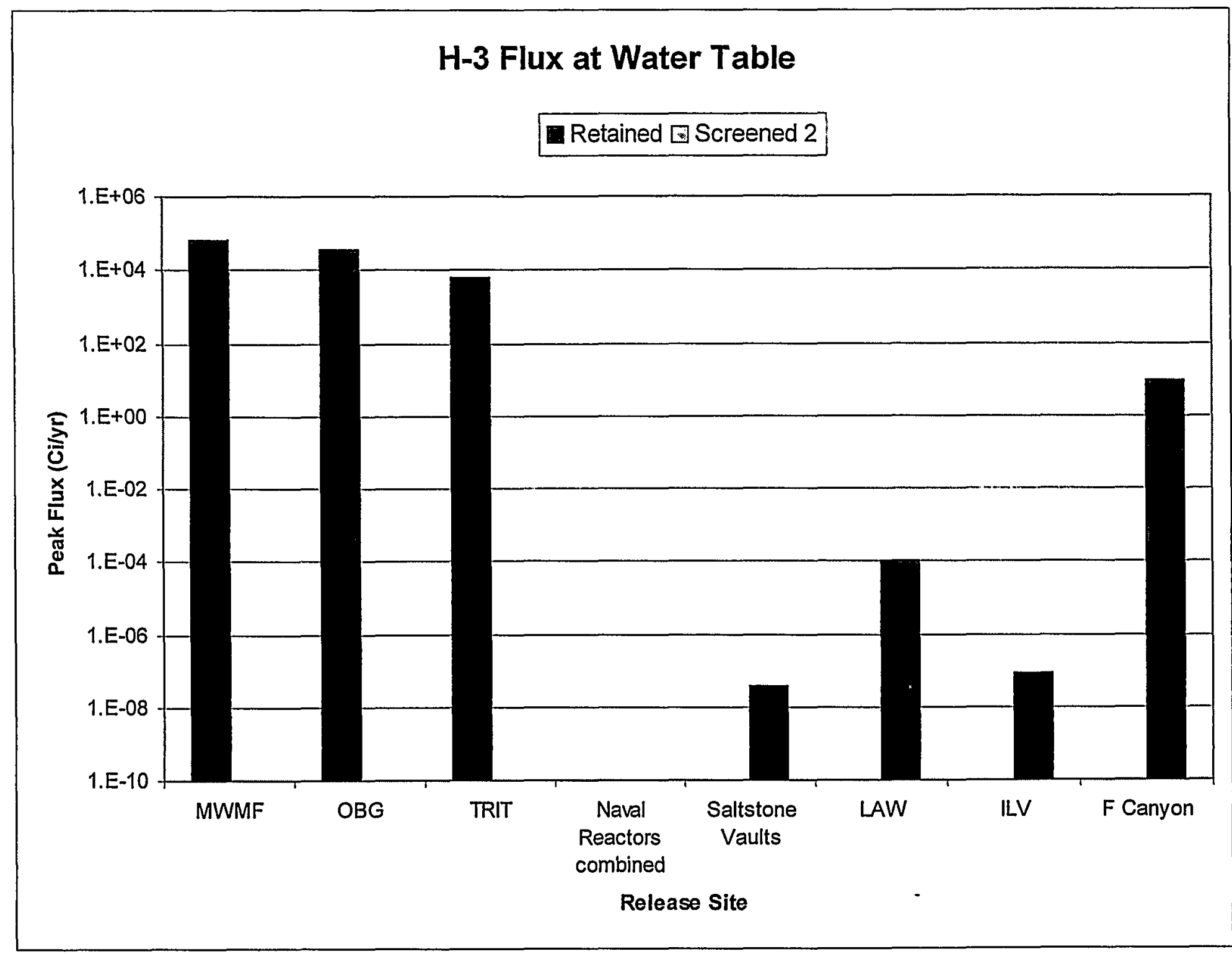

Figure 6.6-6 ${ }^{3} \mathrm{H}$ Inventories for All Facilities Screened by Flux at Water Table 


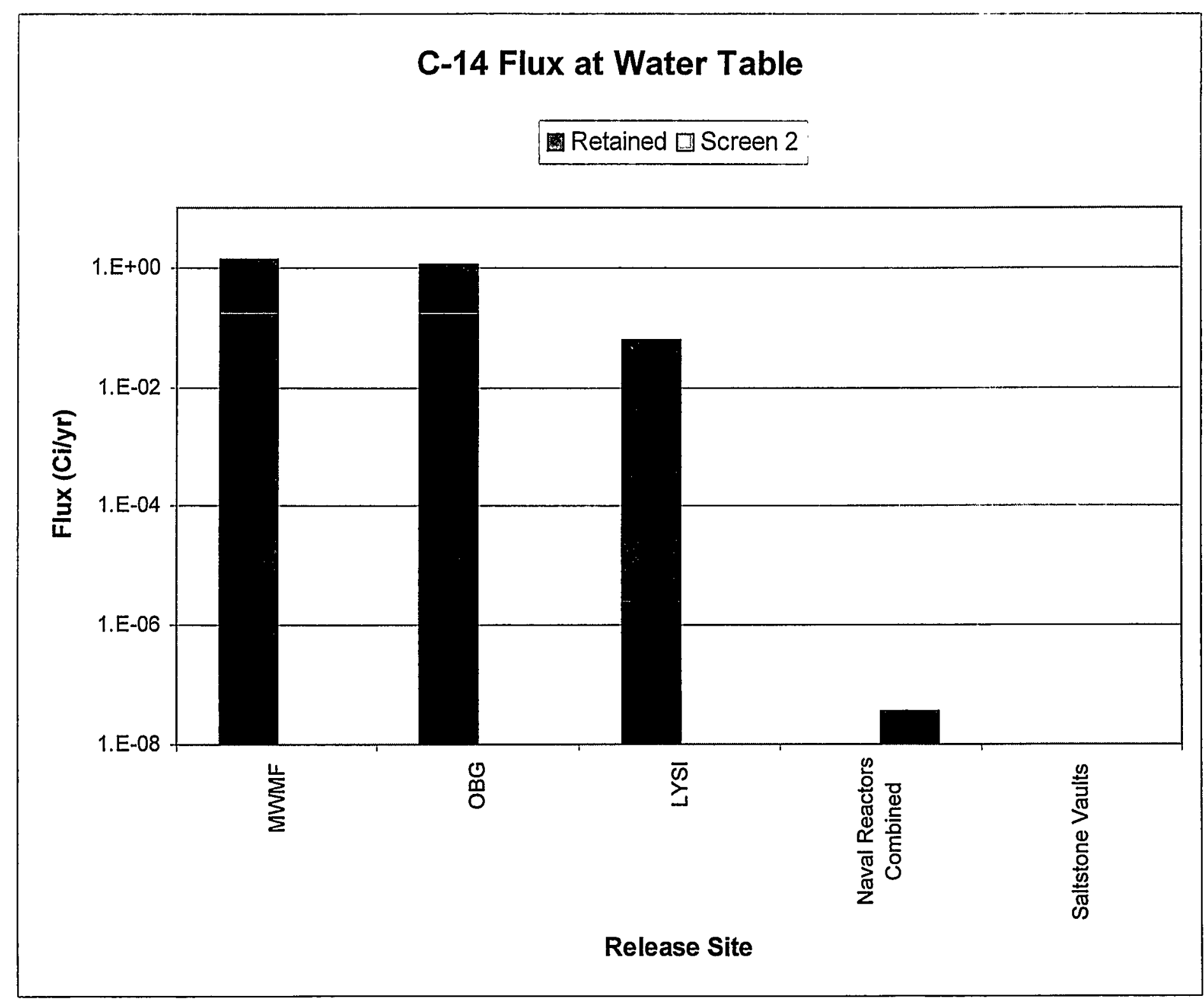

Figure 6.6-7 ${ }^{14} \mathrm{C}$ Inventories for All Facilities Screened by Flux at Water Table 


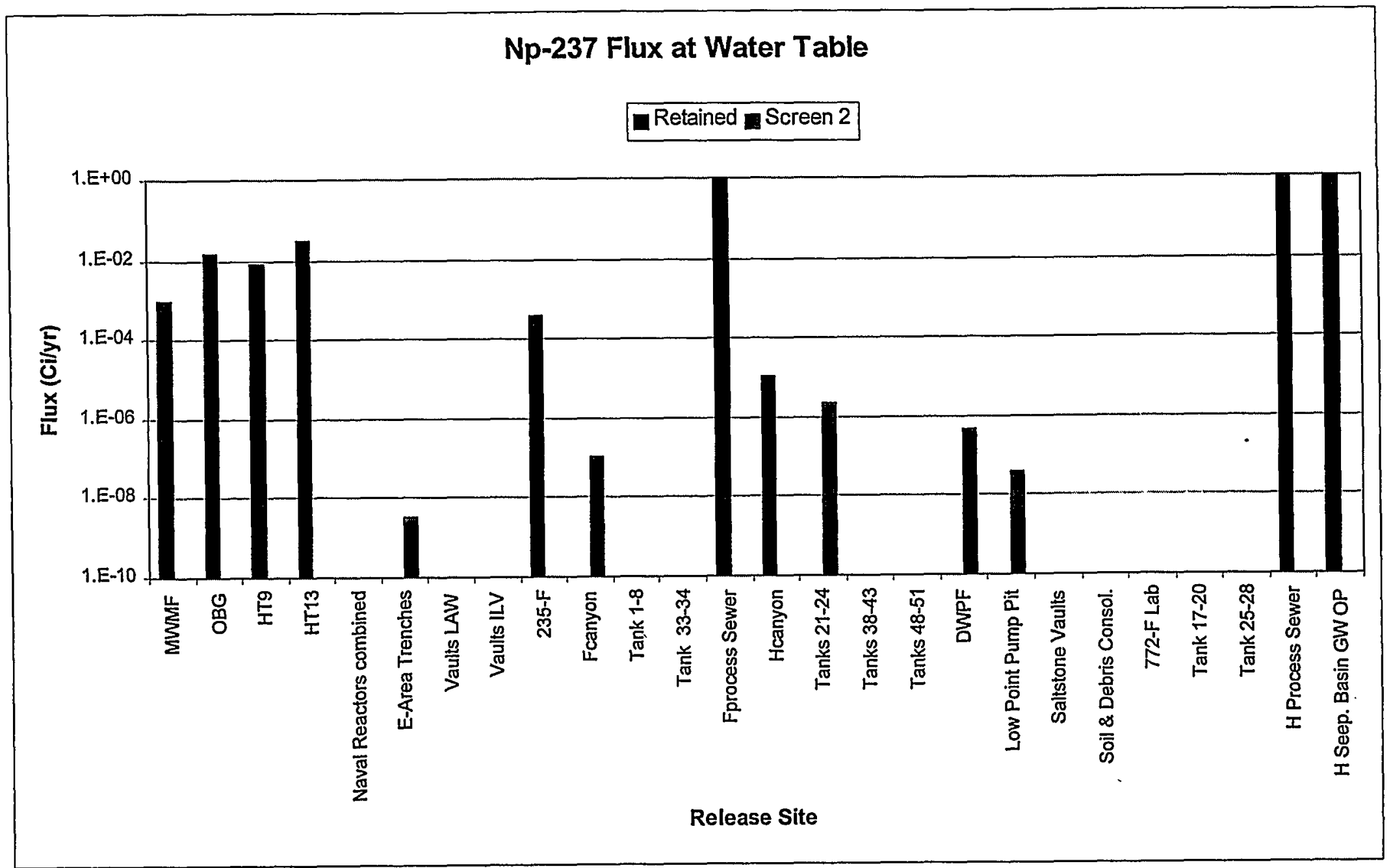

Figure 6.6-8 ${ }^{237} \mathrm{~Np}$ Inventories for All Facilities Screened by Flux at Water Table 
Table 6.6-2 ${ }^{3}$ H Peak Flux to Water Table ${ }^{2}$

\begin{tabular}{|c|c|c|c|}
\hline \multirow[b]{2}{*}{ Source } & \multirow[b]{2}{*}{$\begin{array}{l}\text { Inventory } \\
\text { (Ci) }\end{array}$} & \multicolumn{2}{|c|}{ Peak Flux at Water Table } \\
\hline & & Time (yr) & $\begin{array}{l}\text { Peak Flux } \\
(\mathrm{Ci} / \mathrm{yr})\end{array}$ \\
\hline \multicolumn{4}{|l|}{$\begin{array}{l}\text { Sources Eliminated During Inventory Screening } \\
\text { Phase }\end{array}$} \\
\hline Saltstone Lysimeters & $7.39 \times 10^{-1}$ & & \\
\hline E-Area Trenches & 8.75 & & \\
\hline 772-F Lab & $1.06 \times 10^{1}$ & & \\
\hline 772-1F Lab & $1.00 \times 10^{-1}$ & & \\
\hline F Process Sewer & $1.11 \times 10^{1}$ & & \\
\hline H Canyon & 1.02 & & \\
\hline ETF Receipt Tank & $7.00 \times 10^{-2}$ & & \\
\hline H Process Sewer & $2.87 \times 10^{1}$ & & \\
\hline DWPF & $6.34 \times 10^{-2}$ & & \\
\hline Low Point Pump Pit & $3.17 \times 10^{-3}$ & & \\
\hline Tank 16 Spill & $5.00 \times 10^{-2}$ & & \\
\hline Tank 37 Spill & $8.41 \times 10^{-2}$ & & \\
\hline Soil and Debris Consol. & $3.71 \times 10^{-2}$ & & \\
\hline \multicolumn{4}{|l|}{$\begin{array}{l}\text { Sources Eliminated During Contaminant Flux } \\
\text { Screening Phase }\end{array}$} \\
\hline Naval Reactors CB/TS and Naval Reactors Head & $4.39 \times 10^{2}$ & Other Screen ${ }^{3}$ & $<1 . \times 10^{-18}$ \\
\hline LAW Vaults & $1.66 \times 10^{6}$ & $85^{4}$ & $9.79 \times 10^{-5}$ \\
\hline ILV Vaults & $8.80 \times 10^{5}$ & $114^{4}$ & $8.54 \times 10^{-8}$ \\
\hline F Canyon & $6.79 \times 10^{1}$ & 23 & 9.2 \\
\hline Saltstone Vaults & $1.90 \times 10^{4}$ & $89^{6}$ & $3.8 \times 10^{-8}$ \\
\hline \multicolumn{4}{|l|}{ Sources Remaining After Both Screening Phases } \\
\hline MWMF & $2.29 \times 10^{6}$ & 35 & $6.25 \times 10^{4}$ \\
\hline OBG & $2.10 \times 10^{6}$ & 20 & $3.6 \times 10^{4}$ \\
\hline TRIT & $3.00 \times 10^{4}$ & 41 & $6.3 \times 10^{3}$ \\
\hline
\end{tabular}

Notes:

${ }^{2}$ Peak time from Figure 4.4-2, Inventory from Table 4.4-2, Peak flux from Table 4.4-5

${ }^{3}$ From Table L.2-1 in WSRC, $1996.13 .5 \mathrm{Ci}$ per barrel after 750 years decays to less than $1 \times 10^{-18} \mathrm{Ci}$.

${ }^{4}$ From Table 4.1-3, WSRC, 1994.

${ }^{5}$ From PATHRAE-RAD computer run

${ }^{6}$ From Table 4.1-3, WSRC 1992. 
Table 6.6-3 ${ }^{14} \mathrm{C}$ Peak Flux to Water Table ${ }^{7}$

\begin{tabular}{|c|c|c|c|}
\hline \multirow[b]{2}{*}{ Site } & \multirow[b]{2}{*}{$\begin{array}{l}\text { Inventory } \\
\quad(\mathrm{Ci})\end{array}$} & \multicolumn{2}{|c|}{ Peak Flux at Water Table } \\
\hline & & $\begin{array}{l}\text { Time } \\
\text { (yr) }\end{array}$ & $\begin{array}{l}\text { Peak Flux } \\
(\mathrm{Ci} / \mathrm{yr})\end{array}$ \\
\hline \multicolumn{4}{|l|}{$\begin{array}{l}\text { Sources Eliminated During Inventory Screening } \\
\text { Phase }\end{array}$} \\
\hline Saltstone Lysimeters & $2.53 \times 10^{-4}$ & & \\
\hline LAW Vaults & $1.70 \times 10^{-1}$ & & \\
\hline ILV Vaults & $2.24 \times 10^{-3}$ & & \\
\hline F Canyon & $2.85 \times 10^{-1}$ & & \\
\hline Tank 1-8 & $1.15 \times 10^{-3}$ & & \\
\hline Tank $17-20$ & $7.80 \times 10^{-3}$ & & \\
\hline Tank $25-28 \&$ \& 44-47 & $3.34 \times 10^{-2}$ & & \\
\hline H Canyon & $4.28 \times 10^{-3}$ & & \\
\hline Tank $9-12$ & $7.97 \times 10^{-4}$ & & \\
\hline Tank 13-16 & $2.88 \times 10^{-4}$ & & \\
\hline Tanks $21-24 \& 29-32 \& 35-37$ & $8.79 \times 10^{-4}$ & & \\
\hline Tanks 38-43 & $5.85 \times 10^{-4}$ & & \\
\hline Tanks 48-51 & $2.08 \times 10^{-4}$ & & \\
\hline Soil and Debris Consol. & $9.06 \times 10^{-2}$ & & \\
\hline \multicolumn{4}{|l|}{$\begin{array}{l}\text { Sources Eliminated During Contaminant Flux } \\
\text { Screening Phase }\end{array}$} \\
\hline $\begin{array}{l}\text { Naval Reactors CB/TS and Naval Reactors Head } \\
\text { Saltstone Vaults }\end{array}$ & $\begin{array}{r}6.79 \times 10^{2} \\
6.50\end{array}$ & $\begin{array}{r}10000^{8} \\
\text { Other Screen }\end{array}$ & $\begin{array}{l}3.60 \times 10^{-8} \\
<1 . \times 10^{-18}\end{array}$ \\
\hline \multicolumn{4}{|l|}{ Sources Remaining After Both Screening Phases } \\
\hline MWMF & $3.72 \times 10^{3}$ & 140 & 1.35 \\
\hline OBG & $3.09 \times 10^{3}$ & 180 & 1.12 \\
\hline LYSI & 1.75 & 180 & $6.18 \times 10^{-2}$ \\
\hline
\end{tabular}

Notes:

${ }^{7}$ Peak time from Figure 4.4-2, Inventory from Table 4.4-2, Peak flux from Table 4.4-5

${ }^{8}$ Peak time from Table L.3-1, WSRC 1996

${ }^{9}$ From Table 4.1-3, WSRC, 1992. 
Table 6.6-4 ${ }^{237}$ Np Peak Flux to Water Table ${ }^{10}$

\begin{tabular}{|c|c|c|c|c|c|}
\hline \multirow[b]{2}{*}{ Site } & \multirow{2}{*}{$\begin{array}{l}{ }^{237} \mathrm{~Np} \\
\text { Inventory } \\
(\mathrm{Ci})\end{array}$} & \multirow{2}{*}{$\begin{array}{l}\mathrm{Z}^{241} \mathrm{Am} \text { Forcing } \\
\text { Consideration } \\
\text { Inventory } \\
\text { (Ci) }\end{array}$} & \multirow{2}{*}{$\begin{array}{l}{ }^{241} \mathrm{Pu} \text { Forcing } \\
\text { Consideration } \\
\text { Inventory } \\
\text { (Ci) }\end{array}$} & \multicolumn{2}{|c|}{ Peak Flux at Water Table } \\
\hline & & & & $\begin{array}{l}\text { Time } \\
(y r)\end{array}$ & $\begin{array}{c}\text { Peak Flux } \\
\text { (Ci/yr) }\end{array}$ \\
\hline \multicolumn{6}{|l|}{$\begin{array}{l}\text { Sources Eliminated During } \\
\text { Inventory Screening Phase }\end{array}$} \\
\hline Saitstone Lysimeters & $2.27 \times 10^{-6}$ & & & & $5.69 \times 10^{-11}$ \\
\hline \multicolumn{6}{|l|}{$\begin{array}{l}\text { Sources Eliminated During } \\
\text { Contaminant Flux } \\
\text { Screening Phase }\end{array}$} \\
\hline $\begin{array}{l}\text { Naval Reactors CB/TS and } \\
\text { Naval Reactors Head } \\
\text { E-Area Trenches } \\
\text { LAW Vaults } \\
\text { ILV Vaults } \\
\text { F Canyon } \\
\text { Tank 1-8 } \\
\text { Tank 33-34 } \\
\text { F Process Sewer } \\
\text { Tanks 21-24 } \\
\text { Tanks 38-43 } \\
\text { Tanks 48-51 } \\
\text { DWPF } \\
\text { Low Point Pump Pit } \\
\text { Saltstone Vaults } \\
\text { Soil and Debris Consol. } \\
\text { 772-F Lab } \\
\text { Tank 17-20 } \\
\text { Tank 25-28 } \\
\text { H Process Sewer } \\
\text { H Seep. Basin GW Op Unit }\end{array}$ & $\begin{array}{l}1.29 \times 10^{-5} \\
8.85 \times 10^{-7} \\
8.69 \times 10^{-3} \\
1.75 \times 10^{-3} \\
3.53 \times 10^{-3} \\
5.25 \times 10^{-2} \\
2.11 \times 10^{-2} \\
\\
2.15 \times 10^{-2} \\
2.45 \times 10^{-2} \\
9.70 \times 10^{-3} \\
1.50 \times 10^{-4} \\
1.52 \times 10^{-2} \\
7.60 \times 10^{-4} \\
5.80 \times 10^{-2} \\
4.97 \times 10^{-8}\end{array}$ & $\begin{array}{l}4.18 \times 10^{-2} \\
7.17 \times 10^{1} \\
4.19 \times 10^{2} \\
2.07 \times 10^{-1} \\
3.93 \times 10^{-1}\end{array}$ & $\begin{array}{r}1.91 \\
4.26 \times 10^{2} \\
6.38 \times 10^{2}\end{array}$ & $\begin{array}{l}\text { Other } \\
\text { Screen } \\
215^{13}\end{array}$ & $\begin{array}{l}\text { NA } \\
3.15 \times 10^{-9} \\
<1 . \times 10^{-18} \\
<1 . \times 10^{-18} \\
1.09 \times 10^{-7} \\
<1 . \times 10^{-18} \\
<1 . \times 10^{-18} \\
\text { Other } \\
\text { Screen } \\
2.28 \times 10^{-6} \\
<1 . \times 10^{-18} \\
<1 . \times 10^{-18} \\
4.68 \times 10^{-7} \\
3.80 \times 10^{-8} \\
\text { NR }{ }^{15} \\
\\
1 \times 10^{-18} \\
1 \times 10^{-18} \\
1 \times 10^{-18} \\
\text { Other } \\
\text { Screen } \\
\text { Other } \\
\text { Screen }\end{array}$ \\
\hline \multicolumn{6}{|l|}{$\begin{array}{l}\text { Sources Remaining After } \\
\text { Both Screening Phases }\end{array}$} \\
\hline $\begin{array}{l}\text { MWMF } \\
\text { OBG } \\
\text { HT9 } \\
\text { HT13 } \\
\text { 235-F } \\
\text { H Canyon }\end{array}$ & $\begin{array}{r}9.59 \times 10^{-2} \\
1.57 \\
3.44 \times 10^{-2} \\
2.04 \times 10^{-2} \\
1.20 \times 10^{1} \\
3.56 \times 10^{-1}\end{array}$ & & & $\begin{array}{r}310 \\
380 \\
610 \\
610 \\
\text { Not Plotted }\end{array}$ & $\begin{array}{c}9.31 \times 10^{-4} \\
1.52 \times 10^{-2} \\
7.89 \times 10^{-3} \\
3.2 \times 10^{-2} 11 \\
\\
3.69 \times 10^{-4} \\
1.10 \times 10^{-5}\end{array}$ \\
\hline \multicolumn{6}{|c|}{$\begin{array}{l}\text { Notes: } \\
{ }^{10} \text { Peak time from Figure } 4.4-2 \text {, Inventory from Table } 4.4-2 \text {, Peak flux from Table } 4.4-5 \\
11 \text { Value is from Figure } 4.4-2 \text { which is higher than } 2.62 \times 10^{-2} \text { shown in Table } 4.4-5 \\
{ }^{12} \text { WSRC } 1996 \text {, Table L.2-3 inventory about } 1 \text { order of magnitude below screen threshold. } \\
{ }^{13} \text { Table } 4.3-5 \text {, WSRC } 1998 \text {. } \\
{ }^{14} \text { Screened out during earlier portion of Composite Analysis. }\end{array}$} \\
\hline
\end{tabular}


Table 6.6-5 Significant Sources

\begin{tabular}{|c|c|c|c|}
\hline Source & Contaminant & $\begin{array}{c}\text { Data } \\
\text { Qualifier }\end{array}$ & Qualifier Title \\
\hline MWMF & $\sqrt{\mathrm{H}}$ & $\overline{2}$ & $\begin{array}{l}\text { Shipping and Disposal Record, Facility } \\
\text { Inventories }\end{array}$ \\
\hline OBG & ${ }^{3} \mathrm{H}$ & 2 & $\begin{array}{l}\text { Shipping and Disposal Record, Facility } \\
\text { Inventories }\end{array}$ \\
\hline TRIT & ${ }^{3} \mathrm{H}$ & 7 & Interviews with Plant Personnel \\
\hline MWMF & ${ }^{14} \mathrm{C}$ & 2 & $\begin{array}{l}\text { Shipping and Disposal Record, Facility } \\
\text { Inventories }\end{array}$ \\
\hline OBG & ${ }^{14} \mathrm{C}$ & 2 & $\begin{array}{l}\text { Shipping and Disposal Record, Facility } \\
\text { Inventories }\end{array}$ \\
\hline LYSI & ${ }^{14} \mathrm{C}$ & 1 & Peer-reviewed Technical Reports \\
\hline MWMF & ${ }^{251} \mathrm{~Np}$ & 2 & $\begin{array}{l}\text { Shipping and Disposal Record, Facility } \\
\text { Inventories }\end{array}$ \\
\hline OBG & ${ }^{237} \mathrm{~Np}$ & 2 & $\begin{array}{l}\text { Shipping and Disposal Record, Facility } \\
\text { Inventories }\end{array}$ \\
\hline HT9 & ${ }^{237} \mathrm{~Np}$ & 3 & Process Modeling \\
\hline HT13 & ${ }^{237} \mathrm{~Np}$ & 3 & Process Modeling \\
\hline $235-F$ & ${ }^{237} \mathrm{~Np}$ & 5 & Process Knowledge \\
\hline H Canyon & ${ }^{237} \mathrm{~Np}$ & 5 & Process Knowledge \\
\hline
\end{tabular}

Rev. 0 
Parameters and distribution types describing each PDF are provided in Table 6.6-6. Case ID's with an $\mathrm{N}$ suffix are lognormal while case ID's with a $\mathrm{T}$ suffix are logtriangular. Sampling details are described in Appendix A.

After inventory sampling, this study deviated from the typical approach. A novel approach was implemented to limit the number of computer runs needed to model contaminant transport. The approach requires the recognition of two key relationships. First, total doses at a stream can be calculated by summing the doses caused by releases from each source. Second, fluxes and doses at a stream from a single source are linearly related to the source inventory, so relative inventory changes produce equal relative dose changes (e.g., if the inventory doubles, then the dose doubles).

These relationships allowed total doses to be calculated in a spreadsheet-type operation after independently modeling the base case for each significant source. The uncertainty study required scaling each source's base results by the relative sample inventory (relative to the base inventory), then summing the scaled results from all sources. The steps are shown in Figure 6.6-9 and are listed in Table 6.6-7.

\section{Validity of Approach}

The basic premises for this approach are as follows:

1) The total dose at a stream equals the sum of the doses from each source

2) The partial dose at a stream from one source is a linear function of the inventory.

The first premise allows each source to be modeled separately. It postulates that the effects from one source are independent of all other sources. This premise requires that the adsorptiondesorption curve be linear and that diffusion results be additive for multiple sources. The transport computer program models the case for a linear adsorption-desorption curve, so the first requirement is satisfied. Diffusion results are not additive where plumes interact from two sources. Vadose zone transport was modeled independently for each source, so no plume interaction was permitted. In the aquifer, advection dominates such that diffusion becomes at least a second or third order effect.

For a single source, the second premise allows that source to be modeled with a base case contaminant inventory to generate a dose at the stream. After calculating the partial dose at the stream for each source separately, those doses are summed to generate the total dose at the stream.

To check the new approach, an initial sample equal to the base inventory was selected at each source and combined to form a check realization set. The total check doses match the earlier CA results that were obtained by simultaneously modeling each source.

\section{Benefits of Approach}

For a single contaminant, the new uncertainty approach requires a separate computer run for each source. For a single contaminant, a traditional uncertainty analysis approach accommodates all sources in a single computer run, but the traditional approach requires separate computer runs for each realization. Because the double screening reduced the number of significant sites, the computer runs for the new approach were substantially reduced. The computer run savings are expressed in Table 6.6-8 for one thousand realizations. 
Table 6.6-6 Input Probability Distributions and Parameters

\begin{tabular}{|c|c|c|c|c|c|c|c|}
\hline $\begin{array}{c}\text { Data } \\
\text { Qualification } \\
\text { Value }\end{array}$ & $\begin{array}{c}\text { Case } \\
\text { ID }\end{array}$ & Area/Location & Isotope & $\begin{array}{l}\text { Median } \\
\text { Activity } \\
\text { (m) }\end{array}$ & $\begin{array}{l}\text { Activity } \\
\text { Range } \\
\text { Factor } \\
\text { (f) }\end{array}$ & $\begin{array}{l}50 \% \text { Probability } \\
\text { Range for } \\
\text { Lognormal } \\
\text { Distribution } \\
{[\mathrm{m} / \mathrm{f}, \mathrm{mf}]}\end{array}$ & $\begin{array}{c}100 \% \\
\text { Probability } \\
\text { Range for } \\
\text { Logtriangular } \\
\text { Distribution } \\
\text { [m/f, mf }\end{array}$ \\
\hline 1 & $1 \mathrm{~N}$ & Lysimeters & ${ }^{14} \mathrm{C}$ & 1.75 & 2 & {$[0.875,3.5]$} & $\cdots$ \\
\hline 2 & $2 \mathrm{~N}$ & Old Burial Ground & ${ }^{3} \mathrm{H}$ & $2.1 \times 10^{6}$ & 5 & $\begin{array}{l}{\left[4.2 \times 10^{5}\right.} \\
\left.1.05 \times 10^{7}\right]\end{array}$ &.-- \\
\hline 2 & $3 N$ & Old Burial Ground & ${ }^{14} \mathrm{C}$ & 3100 & 5 & {$\left[620,1.55 \times 10^{4}\right]$} & --- \\
\hline 2 & $4 N$ & Old Burial Ground & ${ }^{237} \mathrm{~Np}$ & 1.6 & 5 & {$[0.32,8]$} & $\cdots$ \\
\hline 2 & $5 \mathrm{~N}$ & MWMF & ${ }^{3} \mathrm{H}$ & $2,300,000$ & 5 & $\begin{array}{l}{\left[4.6 \times 10^{5}\right.} \\
1.15 \times 10^{7} 7\end{array}$ & --- \\
\hline 2 & $6 \mathrm{~N}$ & MWMF & ${ }^{14} \mathrm{C}$ & 3700 & 5 & {$\left[740,1.85 \times 10^{4}\right]$} & --- \\
\hline 2 & $7 \mathrm{~N}$ & MWMF & ${ }^{237} \mathrm{~Np}$ & 0.096 & 5 & {$[0.0192,0.48]$} & --- \\
\hline 3 & $1 \mathrm{~T}$ & HLW Tanks 9-12 & ${ }^{237} \mathrm{~Np}$ & 0.034 & 20 & -- & {$[0.0017,0.68]$} \\
\hline 3 & $2 \mathrm{~T}$ & HLW Tanks 13-16 & ${ }^{237} \mathrm{~Np}$ & 0.02 & 20 & --- & {$[0.001,0.4]$} \\
\hline 5 & $3 \mathrm{~T}$ & H Canyon & ${ }^{237} \mathrm{~Np}$ & 0.36 & 50 & -- & {$[0.0072,18.0]$} \\
\hline 5 & $4 \mathrm{~T}$ & $235-\mathrm{F}$ & ${ }^{237} \mathrm{~Np}$ & 12.0 & 50 & --- & {$[0.24,600]$} \\
\hline 7 & $5 \mathrm{~T}$ & Tritium Facilities & ${ }^{3} \mathrm{H}$ & 30,000 & 100 & --- & {$\left[300,3.0 \times 10^{6}\right]$} \\
\hline
\end{tabular}




\section{Table 6.6-7 Simplified Uncertainty Approach}

\begin{tabular}{|l|l|l|l|}
\hline Step Number & Inventory & Operation & Results \\
\hline \hline 1 & Base & Sample & 1,000 Sample Inventories \\
\hline 2 & $\begin{array}{l}\text { Each Source's } \\
\text { Base Inventory } \\
\text { Analyzed } \\
\text { Independently }\end{array}$ & Model & $\begin{array}{l}\text { Stream Doses from Each } \\
\text { Source for Base Inventory }\end{array}$ \\
\hline 3 & Sample & $\begin{array}{l}\text { Scale Doses by Sample } \\
\text { Inventory / Base } \\
\text { Inventory }\end{array}$ & $\begin{array}{l}\text { Partial Stream Doses from } \\
\text { Each Source }\end{array}$ \\
\hline Check & $\begin{array}{l}\text { Sum Doses for all } \\
\text { Sources }\end{array}$ & $\begin{array}{l}\text { Total Stream Doses } \\
\text { Facilities }\end{array}$ & $\begin{array}{l}\text { Total Stream Doses for Base } \\
\text { Inventory to check against } \\
\text { CA results that considered } \\
\text { all inventories } \\
\text { simultaneously }\end{array}$ \\
\hline \hline
\end{tabular}




\section{Table 6.6-8 Computer Run Savings}

\begin{tabular}{|l|l|l|l|l|}
\hline & $\begin{array}{l}\text { Number of } \\
\text { Sources }\end{array}$ & $\begin{array}{l}\text { Number of Traditional } \\
\text { Computer Runs }\end{array}$ & $\begin{array}{l}\text { Number of Computer } \\
\text { Runs for New } \\
\text { Approach }\end{array}$ & $\begin{array}{l}\text { Percentage } \\
\text { Savings }\end{array}$ \\
\hline${ }^{3} \mathrm{H}$ & 3 & 1000 & 3 & 99.7 \\
${ }^{14} \mathrm{C}$ & 3 & 1000 & 3 & 99.7 \\
${ }^{237} \mathrm{~Np}$ & 6 & 1000 & 6 & 99.4 \\
TOTAL & 12 & 3000 & 12 & 99.6 \\
\hline
\end{tabular}

Rev. 0 
Total Dose Curve Generation for One Radionuclide

Step One: Develop PDF for Inventory and Sample

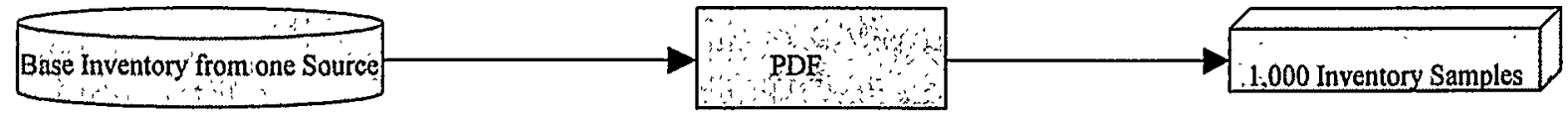

Step Two: Calculate Base Case Dose Curve from each Source by Modeling

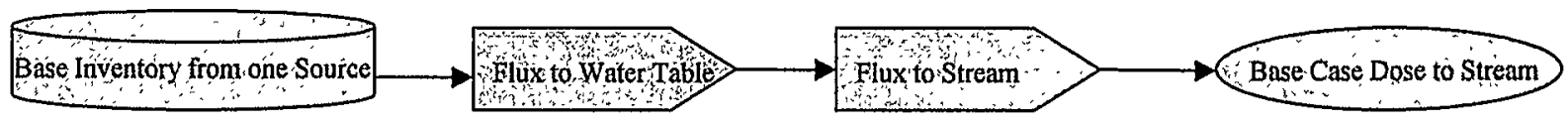

Step Three: Develop Partial Dose Curve from each Source Using Results from Steps 1 and 2

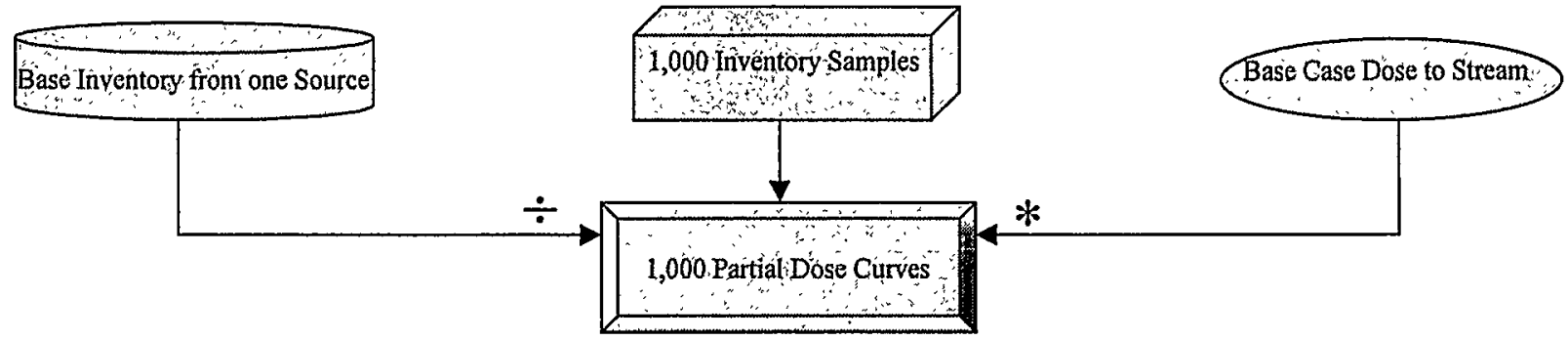

Step Four: Sum Partial Dose Curves from each Source to Generate Total Dose Curve

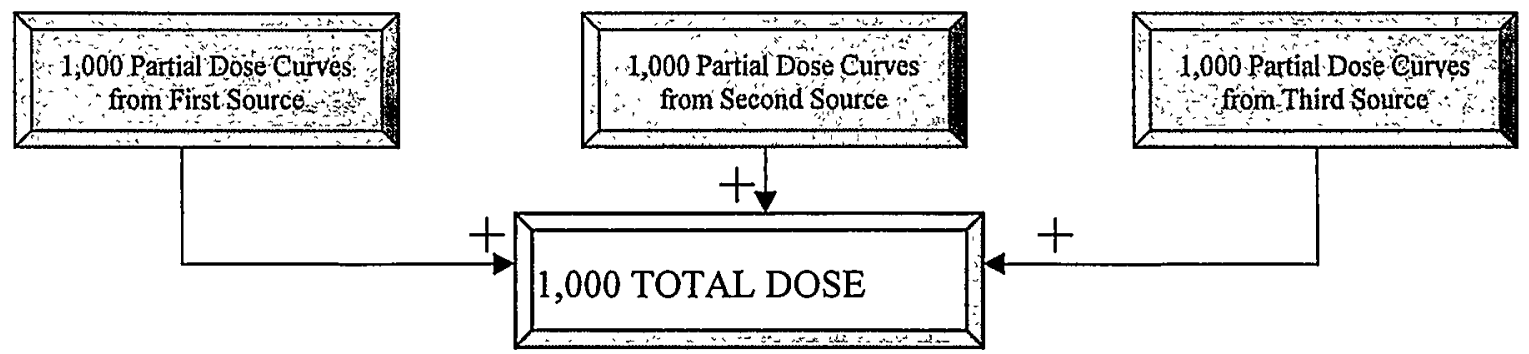

\section{Figure 6.6-9 Simplified Uncertainty Approach}




\subsubsection{Inventory Variation Sampling Results}

For each important radionuclide significant source (see Table 6.6-5), the following sampling, scaling and summing process was implemented:

1. A PDF was developed for the inventory at each source

2. One thousand independent random samples were selected from the inventory PDF at each source

The PDF's for each radionuclide from each significant release site are shown in Figures 6.6-10 through 6.6-12.

\subsubsection{Dose Results from Inventory Variations}

For each important radionuclide, the base case dose curve was generated with transport modeling. The dose curve consists of a plot of doses at a stream versus time. After sampling each significant source inventory (see Table 6.6-5), the samples and the base case dose curve were combined to produce total dose curves by implementing the following method:

1. One thousand partial dose curves for each significant source were generated

2. Each partial dose curve was calculated by multiplying the base case dose curve by a random sample inventory and dividing by the base case inventory

3. Partial dose curves for each significant source were summed to generate one thousand total dose curves.

Thus, one thousand total dose curves were developed for the following scenarios:

\footnotetext{
${ }^{3} \mathrm{H}$ at $\mathrm{FMB}$

${ }^{14} \mathrm{C}$ at $\mathrm{FMB}$

${ }^{237} \mathrm{~Np}$ at FMB

${ }^{14} \mathrm{C}$ at UTR.
}

The complete set of total dose curves for ${ }^{14} \mathrm{C}$ at UTR is shown in Figure 6.6-13. The other plots are not shown because of the vast amount of data required for each plot.

The total dose curves for ${ }^{14} \mathrm{C}$ at UTR slope relatively steeply from time zero to 500 years. After that time, the slope is essentially flat for the remaining 500 years. Since Figure 6.6-13 displays a linear dose axis, only the curves with very high values are distinct from the central mass. The visibly distinct curves displaying the greatest values originate from a combination of high sample inventories from the $\mathrm{OBG}$ and the MWMF (see Figure 6.6-11).

\section{$\underline{\text { Peak Dose Plots }}$}

For each scenario, the peak doses from the total dose curves were collected and sorted to produce a cumulative frequency plot. These plots are shown in Figures 6.6-14 through 6.6-17. Additionally, sorted doses were collected in bins. These histograms are shown in Figures 6.6-18 through 6.6-21. 


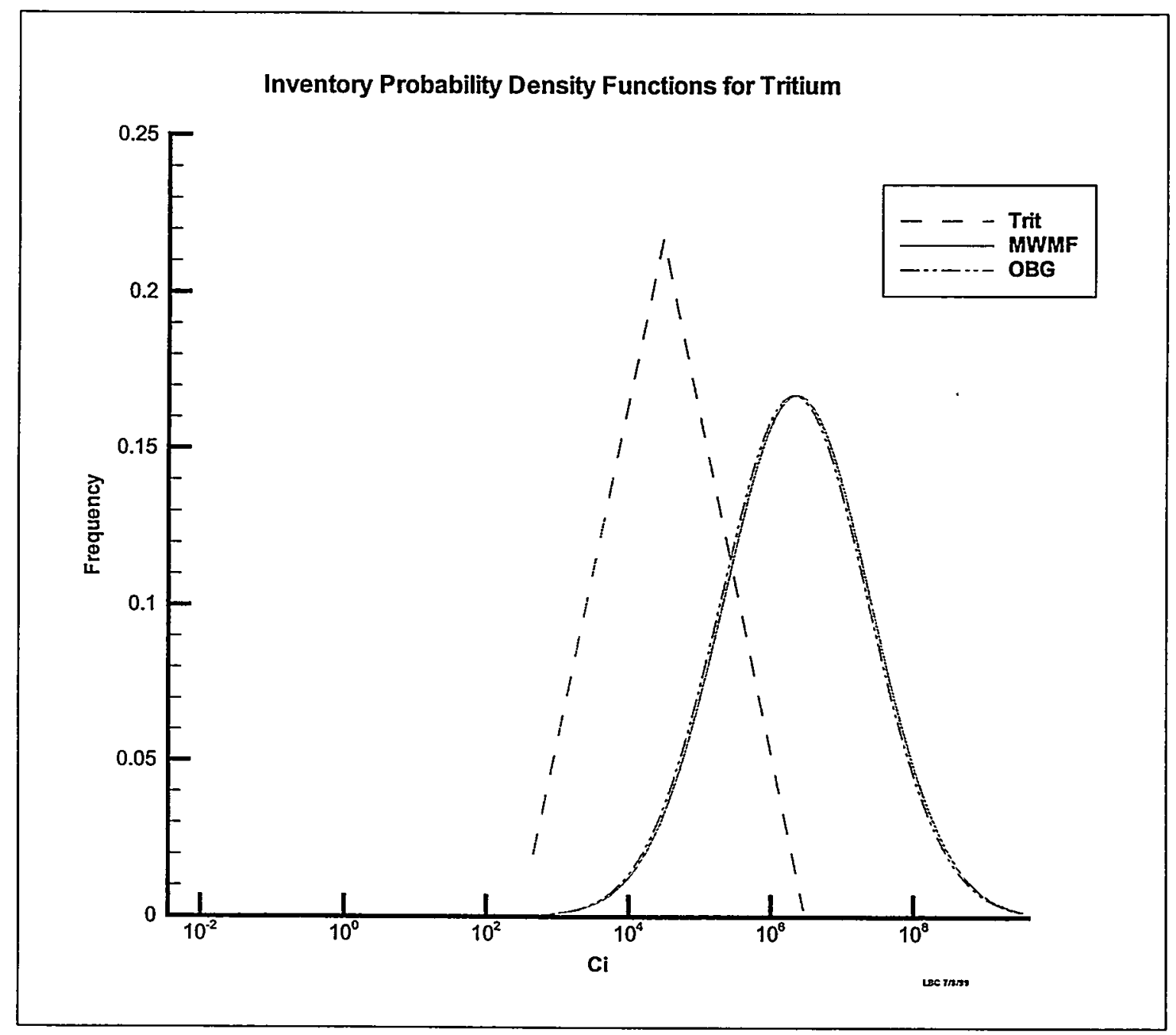

Figure 6.6-10 Probability Density Function for ${ }^{3} \mathbf{H}$

Rev. 0 


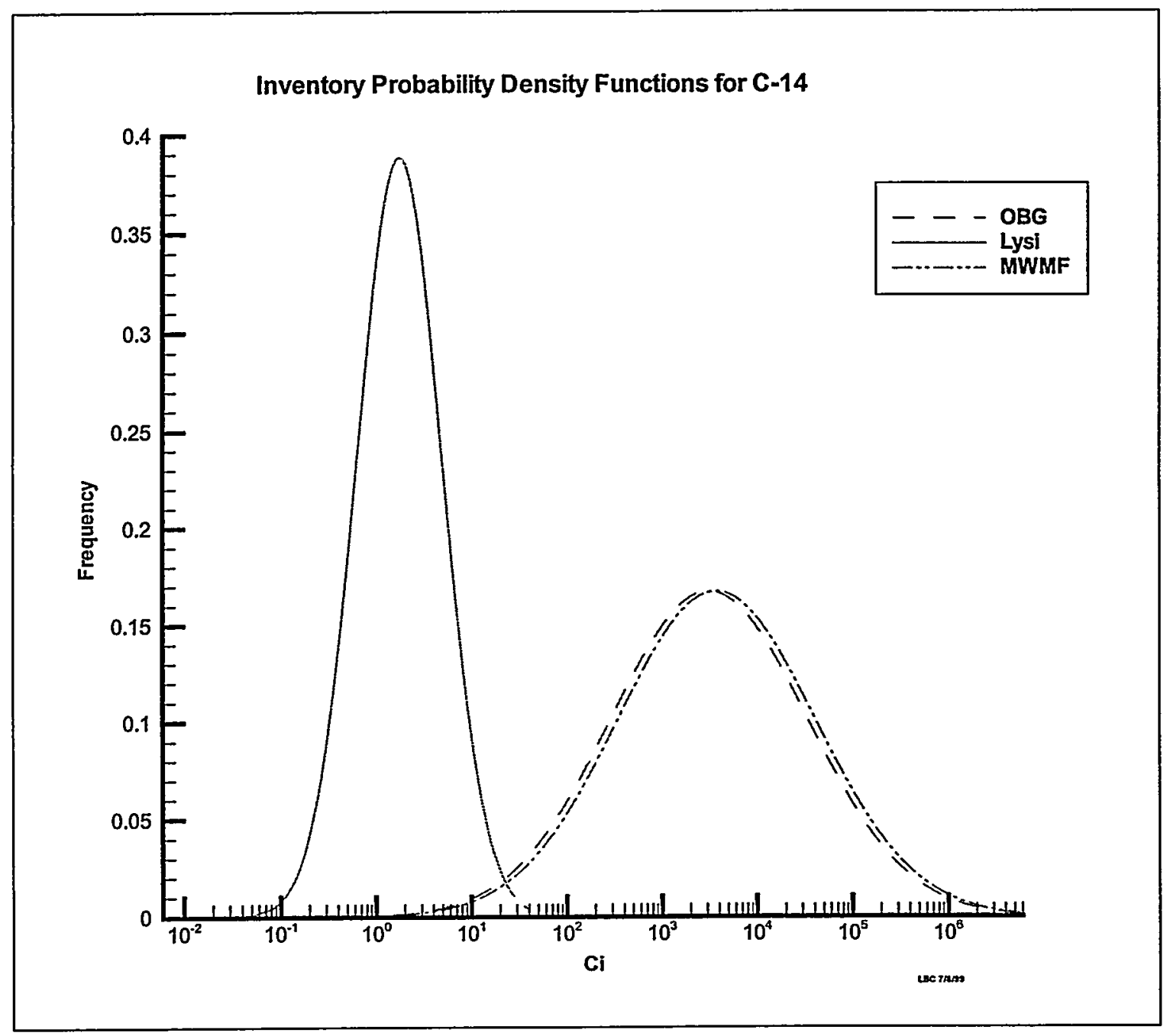

Figure 6.6-11 Probability Density Function for ${ }^{14} \mathrm{C}$ 


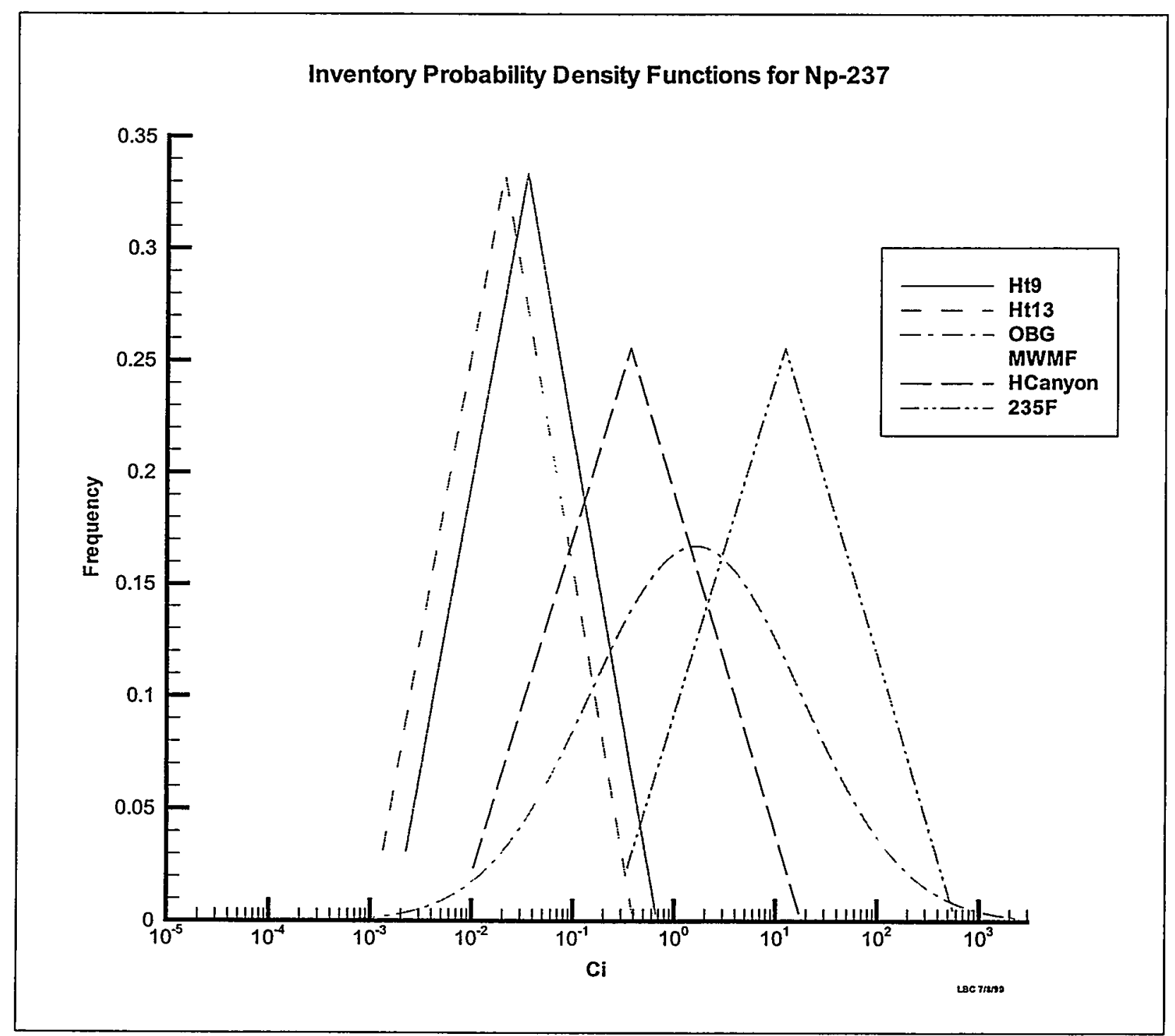

Figure 6.6-12 Probability Density Function for ${ }^{237} \mathrm{~Np}$ 


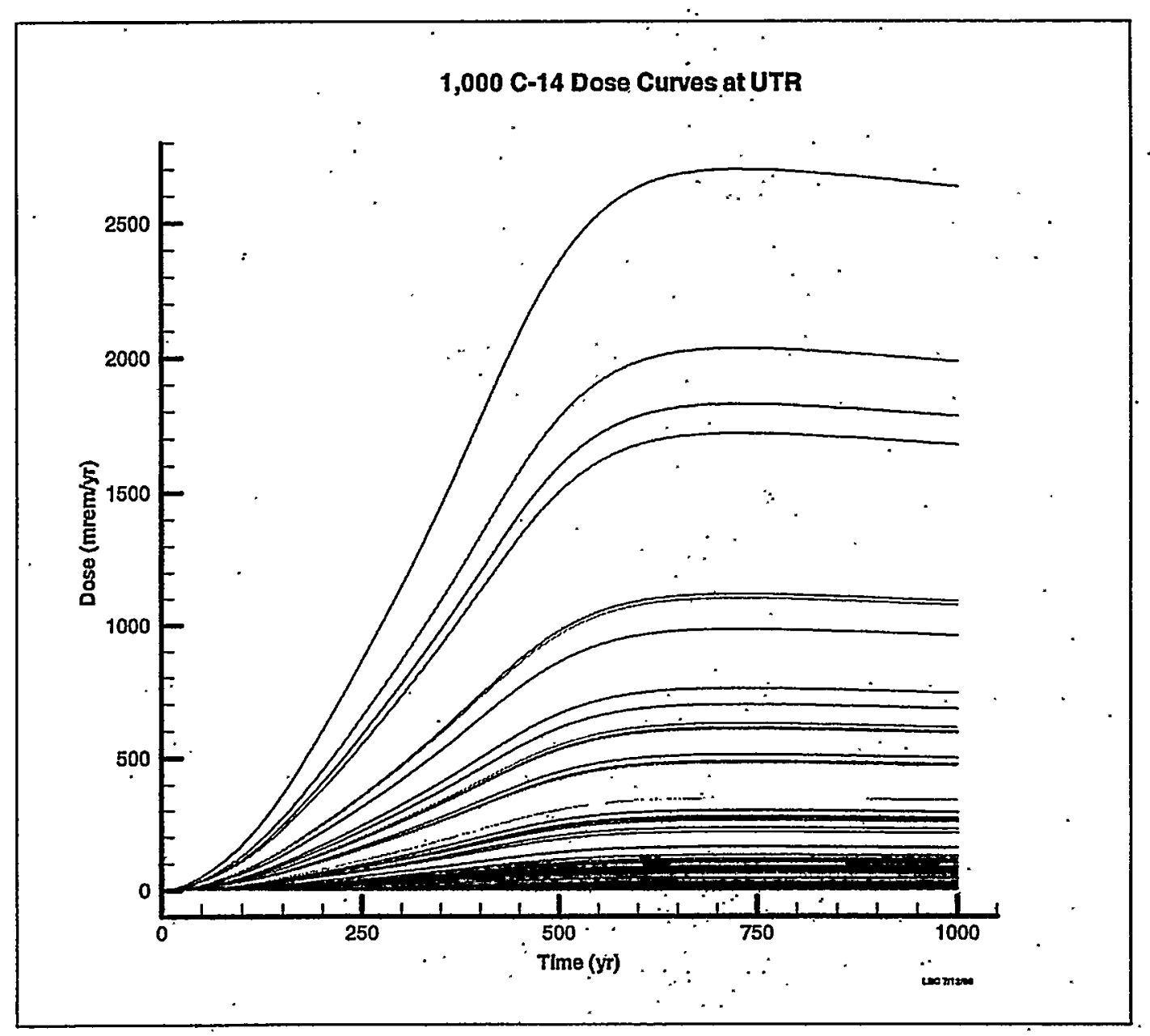

Figure 6.6-13 One Thousand Dose Response Curves for ${ }^{14} \mathrm{C}$ at UTR 


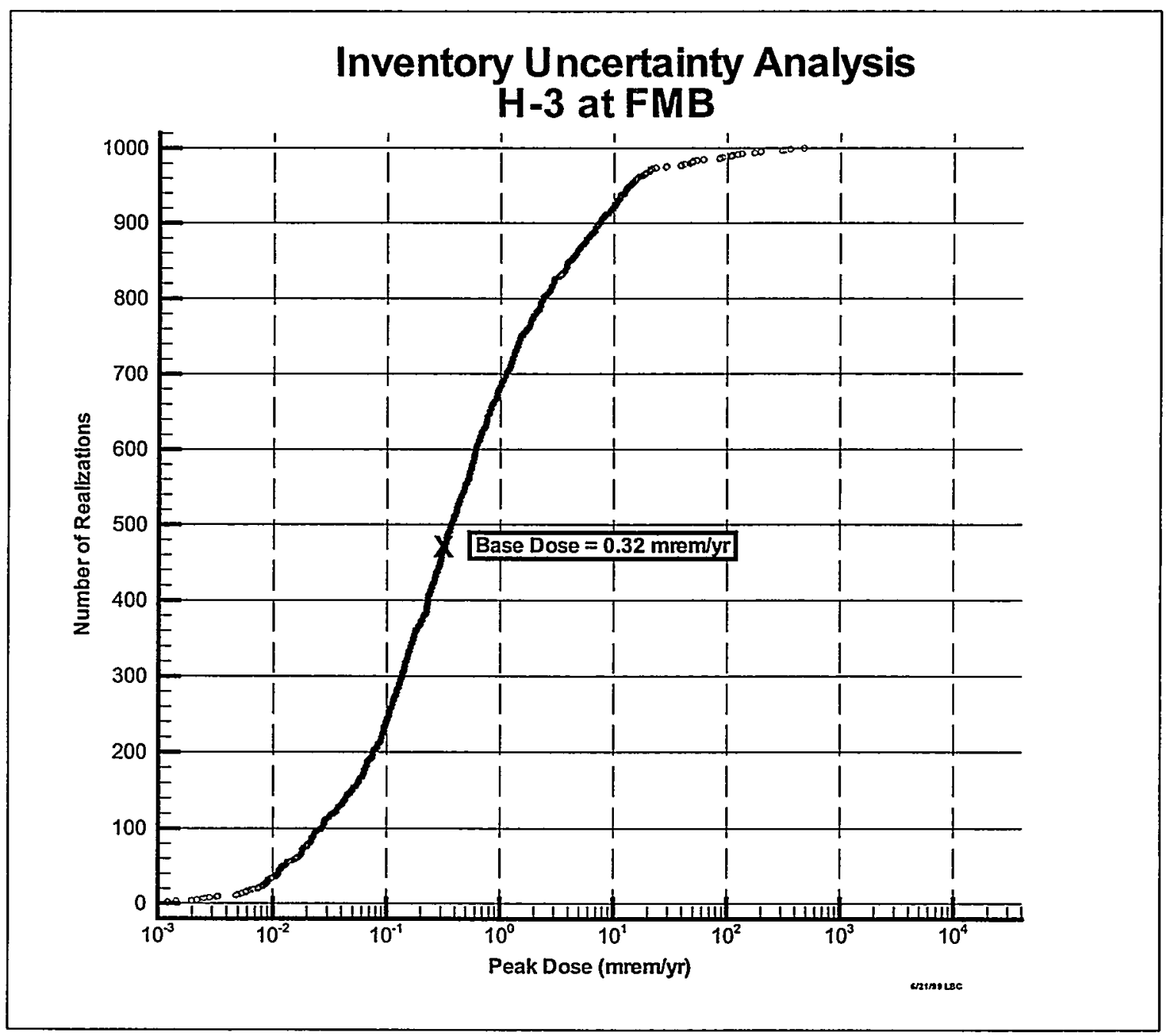

Figure 6.6-14 Peak Dose Cumulative Frequency Plot of ${ }^{3} \mathrm{H}$ at FMB 


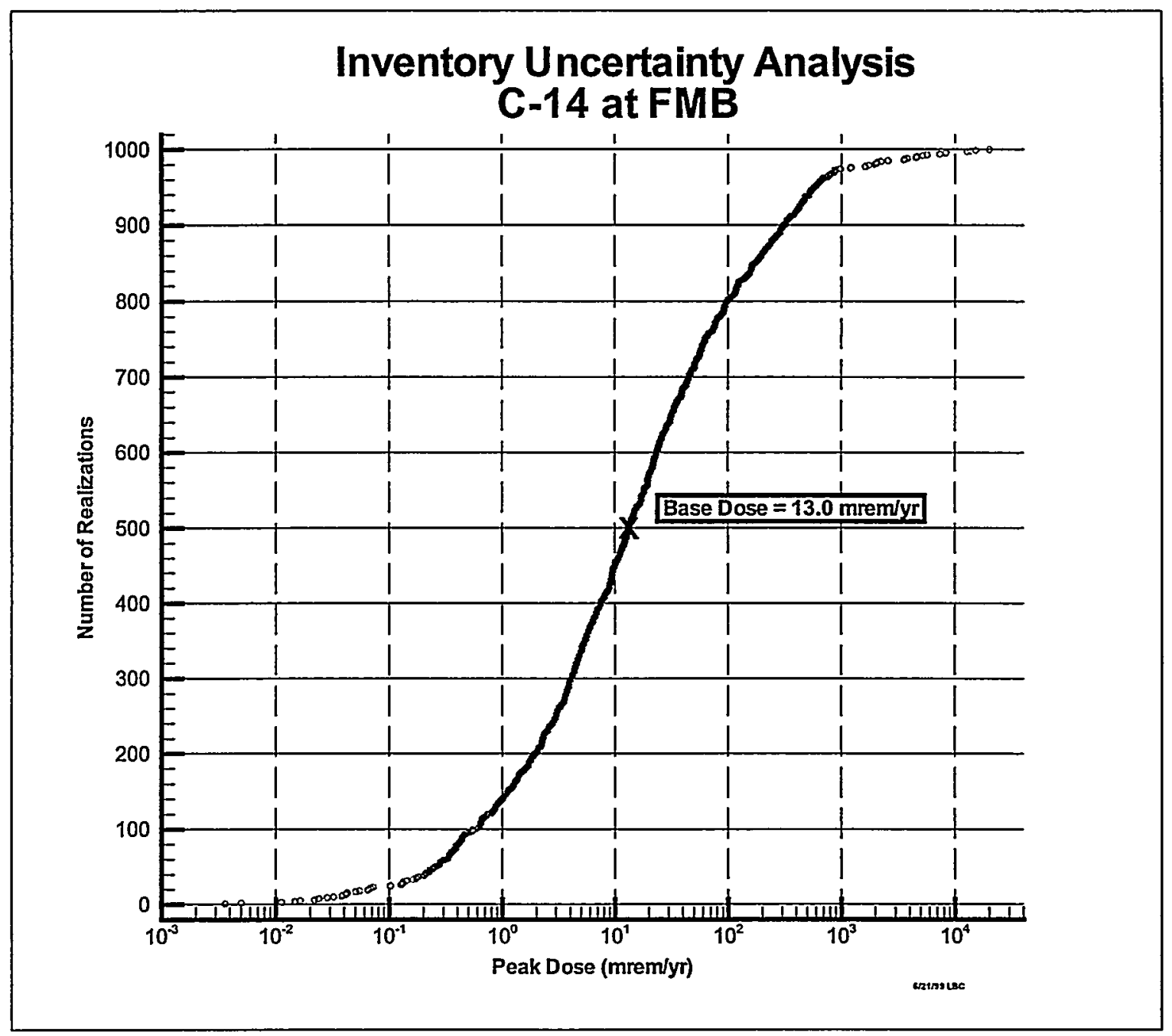

Figure 6.6-15 Peak Dose Cumulative Frequency Plot of ${ }^{14} \mathrm{C}$ at FMB

Rev. 0 


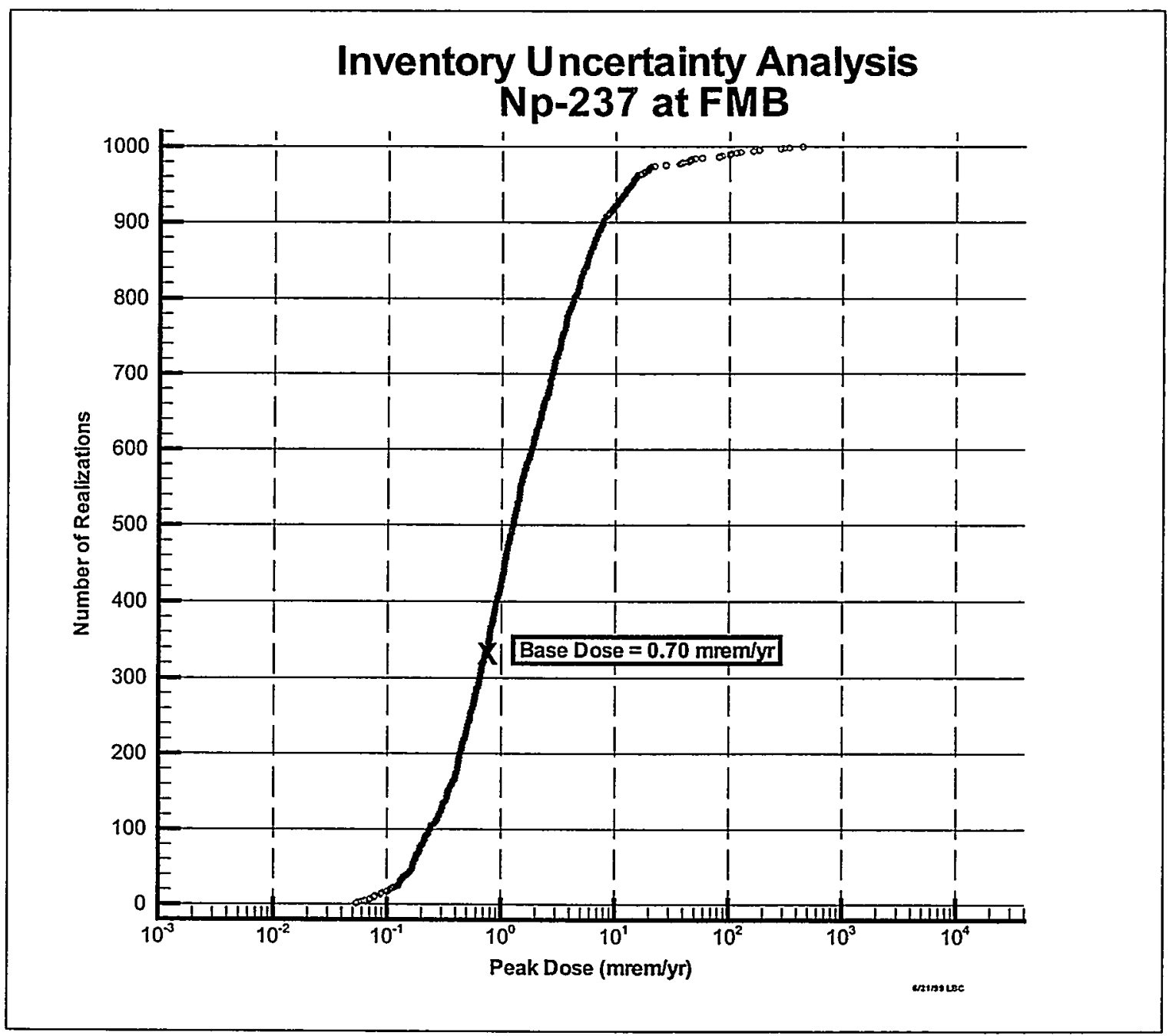

Figure 6.6-16 Peak Dose Cumulative Frequency Plot of ${ }^{237} \mathrm{~Np}$ at FMB 


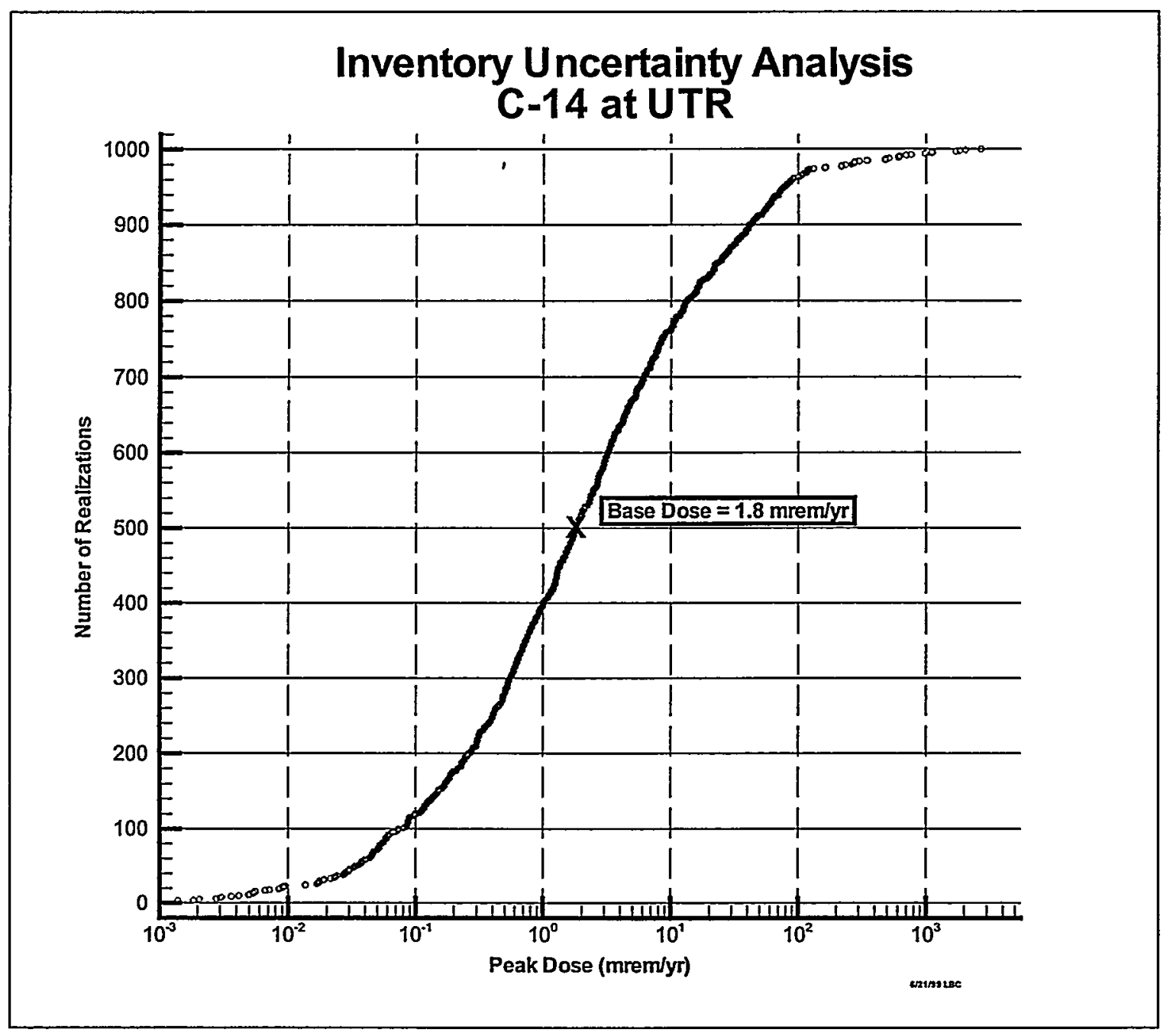

Figure 6.6-17 Peak Dose Cumulative Frequency Plot of ${ }^{14} \mathrm{C}$ at UTR 


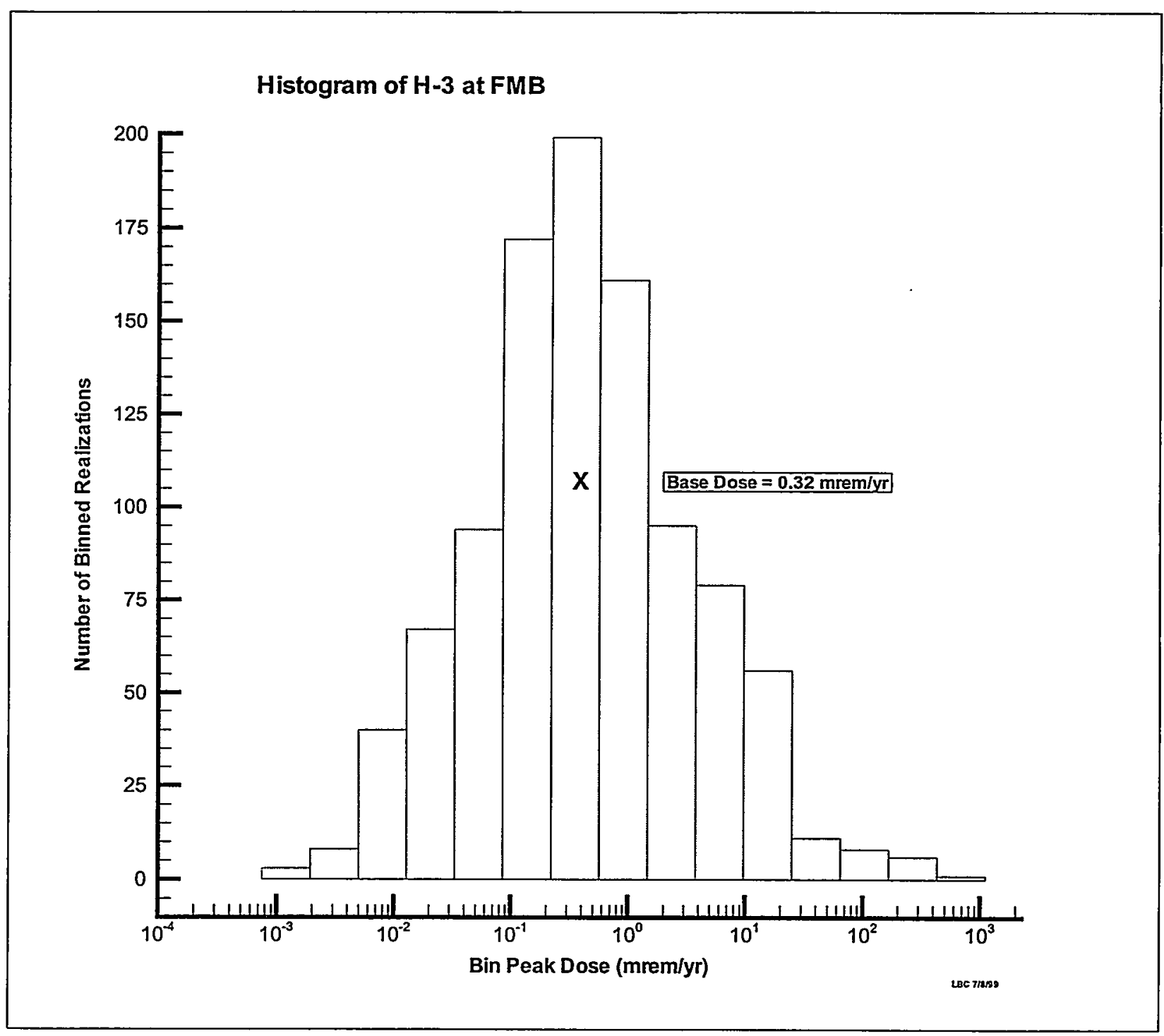

Figure 6.6-18 Peak Dose Histogram of ${ }^{3} \mathrm{H}$ at FMB 


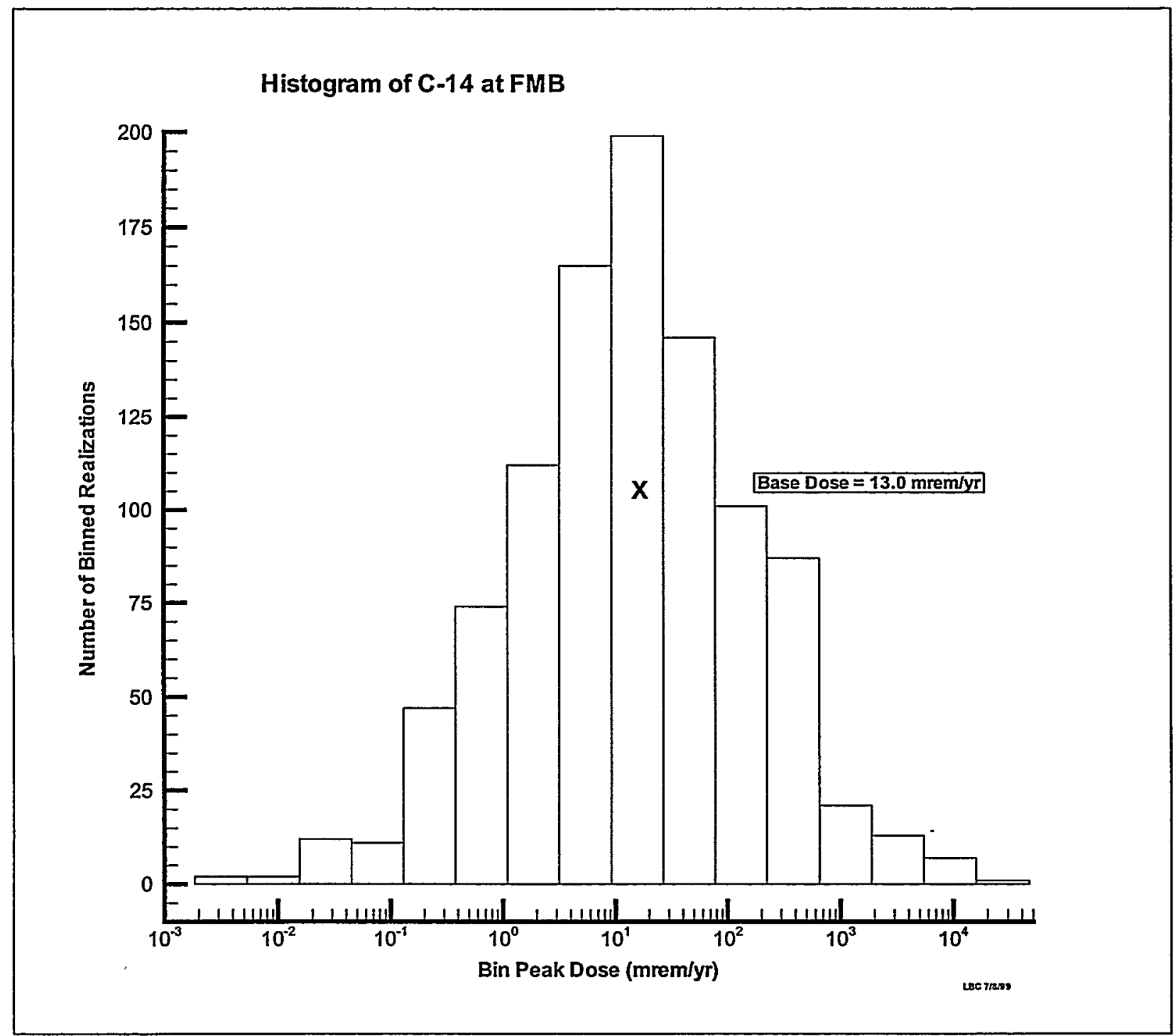

Figure 6.6-19 Peak Dose Histogram of ${ }^{14} \mathrm{C}$ at FMB

Rev. 0 


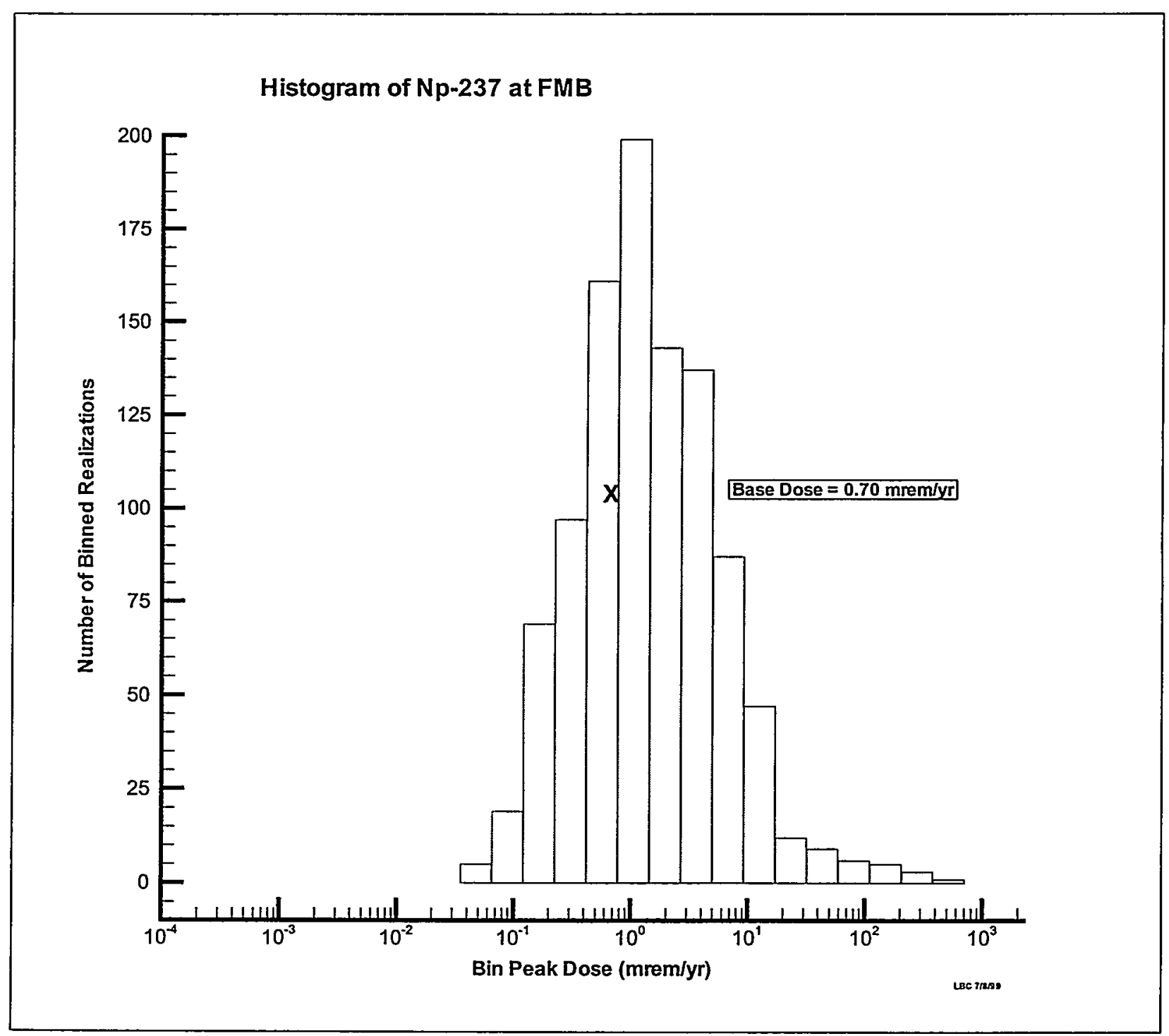

Figure 6.6-20 Peak Dose Histogram of ${ }^{237} \mathrm{~Np}$ at FMB 


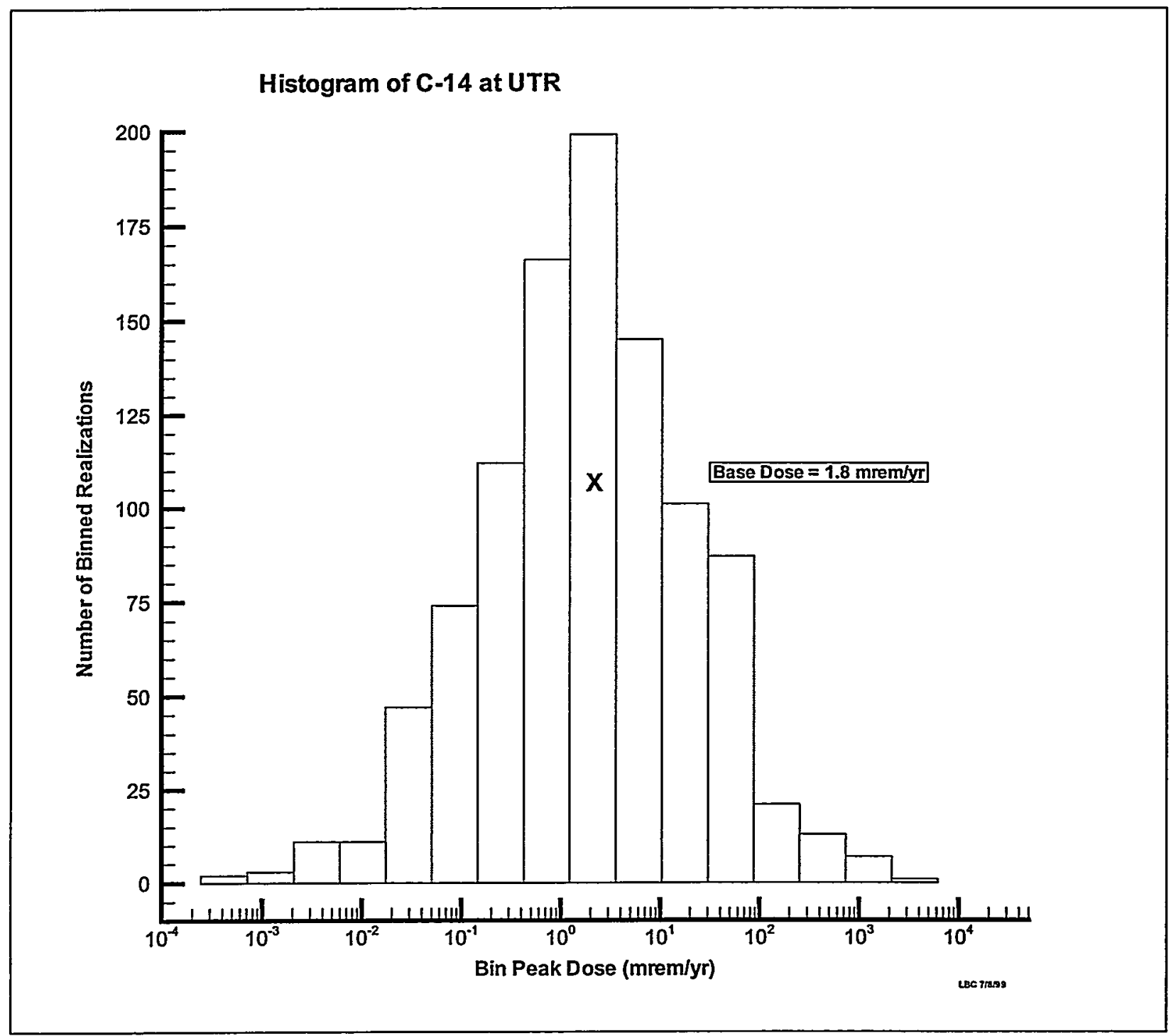

Figure 6.6-21 Peak Dose Histogram of ${ }^{14} \mathrm{C}$ at UTR

Rev. 0 
The peak total dose cumulative frequency plot for ${ }^{3} \mathrm{H}$ at FMB (see Figure 6.6-14) and its associated histogram (see Figure 6.6-18) reveal an almost lognormal distribution of results. The most important sources based on flux to the water table are the MWMF and the OBG (see Figure 4.4-2). The inventory PDFs (see Figure 6.6-10) for the MWMF and the OBG are both lognormal, thus the results should be essentially lognormal.

The peak total dose cumulative frequency plot for ${ }^{14} \mathrm{C}$ at $\mathrm{FMB}$ (see Figure 6.6-15) and its associated histogram (see Figure 6.6-19) reveal an almost lognormal distribution of results, although there appears to be a slight skew to the right. The most important sources based on flux to the water table are MWMF and OBG (see Figure 4.4-1). The inventory PDFs (see Figure 6.6-11) for MWMF and OBG are both lognormal, thus the results should be essentially lognormal.

The peak total dose cumulative frequency plot for ${ }^{237} \mathrm{~Np}$ at FMB (see Figure 6.6-16) and its associated histogram (see Figure 6.6-20) reveal an asymmetrical distribution of results. The peak bin occurs around $1 \mathrm{Ci}$. To the left, the distribution steps down rapidly with very little tail. To the right, the distribution steps down more gradually with much more of a tail. The most important sources based on flux to the water table are HT13, the OBG, and HT9 (see Figure 4.44). The inventory PDFs (see Figure 6.6-12) for HT13, the OBG, and HT9 are logtriangular, lognormal, and logtriangular, respectively, thus the results generally would be asymmetrical.

For ${ }^{237} \mathrm{~Np}$, the total dose for all base case inventories occurs at about the $33^{\text {rd }}$ percentile of sampled peak doses. The other important radionuclides have an all base case total dose very near the $50^{\text {th }}$ percentile of sampled peak doses. This apparent anomaly is likely caused by the interaction of three major sources with similar peaks occurring at slightly different times and by the mixture of lognormal and logtriangular inventory distributions. If one source's partial peak dose at FMB is greater than the base case peak total dose, then it does not matter what the other partial peak doses are. Because the very high peak doses are more important than the very low peak doses, the peak total dose curve tends to be skewed toward the higher end.

The time of the peak total dose at FMB for the base case was 476 years. The times of the peak total doses from the uncertainty analysis ranged from 428 years to 496 years, indicating that multiple sources were affecting the results. Table 6.6-9 shows that HT13 has the most influence, but OBG and HT9 are almost as important. Table 6.6-9 also shows that the times of the partial dose peaks are close. The time for the peak total dose decreased when OBG's influence increased and the time for the peak total dose increased when HT9's influence increased.

The peak total dose cumulative frequency plot for ${ }^{14} \mathrm{C}$ at UTR (see Figure 6.6-17) and its associated histogram (see Figure 6.6-21) reveal an almost lognormal distribution of results, although there appears to be a slight skew to the right. The most important sources based on flux to the water table are the MWMF and the OBG (see Figure 4.4-1). The inventory PDFs (see Figure 6.6-11) for the MWMF and the OBG are both lognormal, thus the results should be essentially lognormal. 
Table 6.6-9 ${ }^{237} \mathrm{~Np}$ Major Peaks

\begin{tabular}{|l|l|l|l|l|}
\hline Source & $\begin{array}{l}\text { Peak Water Table } \\
\text { Flux (Ci/yr) }\end{array}$ & $\begin{array}{l}\text { Time } \\
(\mathrm{yr})\end{array}$ & $\begin{array}{l}\text { Peak Dose at FMB } \\
(\mathrm{mrem} / \mathrm{yr})\end{array}$ & $\begin{array}{l}\text { Time } \\
(\mathrm{yr})\end{array}$ \\
\hline OBG & $1.52 \times 10^{-2}$ & 358 & $2.86 \times 10^{-1}$ & 364 \\
HT9 & $8.28 \times 10^{-3}$ & 316 & $1.14 \times 10^{-1}$ & 506 \\
HT13 & $2.62 \times 10^{-2}$ & 316 & $3.80 \times 10^{-1}$ & 492 \\
\hline
\end{tabular}




\subsection{References}

Flach, G. P., 1998, Impact of F- and H-Area Pump-Treat-Reinject Remediation Systems on the Old Radioactive Waste Burial Ground (U), SRT-EST-98-154.

Flach, G. P. and M. K. Harris, 1997, Integrated hydrogeological model of the General Separations Area (U); Volume 2: Groundwater flow model, WSRC-TR-96-0399.

WSRC, 1997. Appendix L, Naval Reactor Waste Disposal, WSRC-RP-94-218, Westinghouse Savannah River Company, Aiken, SC.

WSRC, 1992. Radiological Performance Assessment for the Z-Area Saltstone Disposal Facility (U), WSRC-RP-92-1360, Westinghouse Savannah River Company, Aiken, SC.

WSRC, 1996. Appendix L, Naval Reactor Waste Disposal (U), WSRC-RP-94-218, Westinghouse Savannah River Company, Aiken, SC.

WSRC, 1994. Radiological Performance Assessment for the E-Area Vaults Disposal Facility $(U)$, WSRC-RP-94-218, Westinghouse Savannah River Company, Aiken, SC. 
Westinghouse Savannah River Company INTER-OFFICE MEMORANDUM

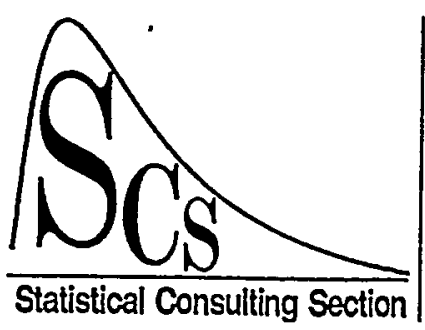

June 24, 1999

To: J.R. Cook, 773-43A

From: C.P. Reeve, 773-42A

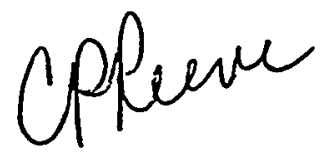

Generation of Lognormal and Logtriqngular Pseudorandom Deviates Based on 50\% and 100\% Coverage Intervals (U)
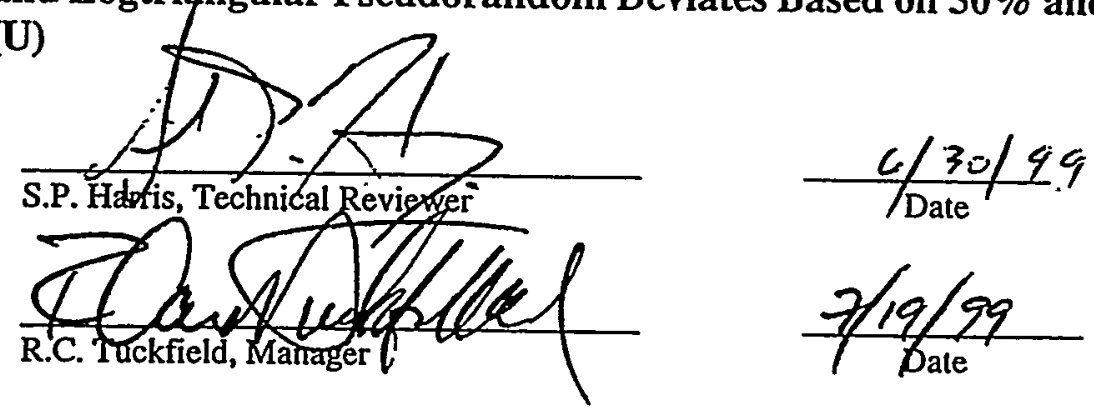

\section{Distribution:}

B.T. Butcher, 773-43A

L.B. Collard, 773-43A

S.P. Harris, 773-42A

R.C. Tuckfield, 773-42A

E.L. Wilhite, 773-43A 


\section{Introduction.}

The purpose of this report is to describe the methodology for generating pseudorandom numbers from probability distributions of the current inventory of three radionuclides at eight SRS facilities. For each radionuclide/facility combination, Jim Cook provided the assumed distribution type, an estimate of the median activity level, and relative ranges that included the best-estimate inventory level with $50 \%$ and $100 \%$ probability. All activities have units of curies.

When the lognormal distribution was assumed, the mean and standard deviation of the parent normal distribution were obtained from the input median and $50 \%$ relative range. When the logtriangular distribution was assumed, the median and range of the parent triangular distribution were obtained from the input median and $100 \%$ range. Pseudorandom deviates from the parent distributions were exponentiated to produce deviates from the desired distributions. Computational details are given in section 2 .

The input parameters describing the assumed distributions are summarized in Table 1 below. Note the correspondence between the data qualification value and the range factor.

Table 1. Input Probability Distributions and Parameters

\begin{tabular}{|c|c|c|c|c|c|c|c|}
\hline $\begin{array}{l}\text { Data } \\
\text { Qualifi- } \\
\text { Cation } \\
\text { Value }\end{array}$ & $\begin{array}{c}\text { Case } \\
\text { ID }\end{array}$ & Area/Location & Isotope & $\begin{array}{l}\text { Median } \\
\text { Activity } \\
\text { (m) }\end{array}$ & $\begin{array}{c}\text { Activity } \\
\text { Range } \\
\text { Factor } \\
\text { (f) }\end{array}$ & $\begin{array}{l}\text { 50\% Probability } \\
\text { Range for } \\
\text { Lognormal } \\
\text { Distribution } \\
\text { [m/f, mf] }\end{array}$ & $\begin{array}{l}100 \% \text { Probability } \\
\text { Range for } \\
\text { Logtriangular } \\
\text { Distribution } \\
\text { [m/f, mf] }\end{array}$ \\
\hline I & IN & Lysimeters & C-14 & 1.75 & 2 & {$[0.875,3.5]$} & -- \\
\hline 2 & $2 \mathrm{~N}$ & Old Burial Ground & $\mathrm{H}-3$ & $2.1 \mathrm{E} 6$ & 5 & {$[4.2 \mathrm{E} 5,1.05 \mathrm{E} 7]$} & $\cdots$ \\
\hline 2 & $3 \mathrm{~N}$ & Old Burial Ground & $\mathrm{C}-14$ & 3100 & 5 & {$[620,1.55 \mathrm{E} 4]$} & $\ldots$ \\
\hline 2 & $4 \mathrm{~N}$ & Old Burial Ground & $\mathrm{Np}-237$ & 1.6 & 5 & {$[0.32,8]$} & --- \\
\hline 2 & $5 \mathrm{~N}$ & MWMF & $\mathrm{H}-3$ & $2,300,000$ & 5 & {$[4.6 \mathrm{E} 5,1.15 \mathrm{E} 7]$} & $\ldots$ \\
\hline 2 & $6 \mathrm{~N}$ & MWMF & $\mathrm{C}-14$ & 3700 & 5 & {$[740,1.85 \mathrm{E} 4]$} & $\cdots$ \\
\hline 2 & $7 \mathrm{~N}$ & MWMF & Np-237 & 0.096 & 5 & {$[0.0192,0.48]$} & $-\cdots$ \\
\hline 3 & $1 \mathrm{~T}$ & HLW Tanks 9-12 & $\mathrm{Np}-237$ & 0.034 & 20 & - & {$[0.0017,0.68]$} \\
\hline 3 & $2 \mathrm{~T}$ & HLW Tanks $13-16$ & Np-237 & 0.02 & 20 & - & {$[0.001,0.4]$} \\
\hline 5 & $3 \mathrm{~T}$ & H Canyon & Np-237 & 0.36 & 50 & --- & {$[0.0072,18.0]$} \\
\hline 5 & $4 \mathrm{~T}$ & $235-\mathrm{F}$ & $\mathrm{Np}-237$ & 12.0 & 50 & - & {$[0.24,600]$} \\
\hline 7 & $5 \mathrm{~T}$ & Tritium Facilities & $\mathrm{H}-3$ & 30,000 & 100 & $-\cdots$ & {$[300,3.0 \mathrm{E} 6]$} \\
\hline
\end{tabular}

\section{Discussion.}

\subsection{Generation of Lognormal Deviates.}

For cases $1 \mathrm{~N}-7 \mathrm{~N}$ in Table 1 , pseudorandom deviates were generated from a lognormal distribution for which $m / f, m$, and $m f$ are the $25 \%, 50 \%$ and $75 \%$ quantiles, respectively. The corresponding quantiles for the parent normal distribution are $\ln m-\ln f, \ln m$, and $\ln m+\ln f$. The central $50 \%$ of a normal distribution with mean, $\mu$, and standard deviation, $\sigma$, is contained in the interval $[\mu-0.6745 \sigma, \mu+0.6745 \sigma]$. It follows that the parent normal distribution has $\mu=\ln m$ and $\sigma=\ln f 10.6745$. If $Z_{i}$ is a standard normal deviate (mean zero and standard deviation one), as shown in Figure 1a, then the desired lognormal deviate, $Y_{i}$, is obtained by 


$$
Y_{i}=\exp \left\{\mu+Z_{i} \sigma\right\}=\exp \left\{\ln m+Z_{i} \ln f / 0.6745\right\}
$$

One thousand such lognormal deviates were generated for each of cases $1 \mathrm{~N}-7 \mathrm{~N}$. The standard normal deviates were generated by a commercially available computer subroutine.

The probability density function for the standard lognormal distribution is plotted in Figure 1b.

\subsection{Generation of Logtriangular Deviates.}

For cases 1T-5T in Table 1, pseudo-random deviates were generated from a logtriangular distribution for which $m / f, m$, and $m f$ are the $0 \%, 50 \%$ and $100 \%$ quantiles, respectively. The corresponding quantiles for the parent triangular distribution are $\ln m-\ln f, \ln m$, and $\ln m+\ln f$. If $T_{i}$ is a standard triangular deviate (mean zero, range $[-1,1]$ ), as shown in Figure 2a, then the desired logtriangular deviate, $Y_{i}$, is obtained by

$$
Y_{i}=\exp \left\{\ln m+T_{i} \ln f\right\}
$$

One thousand such logtriangular deviates were generated for each of cases 1T-5T using the following computer algorithm:

1) Generate a standard uniform deviate, $U_{i}$ (mean zero and range $[0,1]$ );

2) If $U_{i} \leq 0.5$, set $T_{i}=\sqrt{2 U_{i}}-1$; otherwise, set $T_{i}=1-\sqrt{2\left(1-U_{i}\right)}$;

3) Set $Y_{i}=\exp \left\{\ln m+T_{i} \ln f\right\}$.

The standard uniform deviates were generated by a commercially available computer subroutine.

The probability density function for the standard logtriangular distribution is plotted in Figure $2 b$.

\section{Summary.}

Methods have been presented for generating pseudorandom deviates from lognormal and logtriangular distributions with specified parameters. The deviates, 1000 for each case, have been transmitted to you electronically. For the purpose of graphical illustration, the value of the probability density function (p.d.f.) corresponding to each deviate was also transmitted. 
Figure 1a. Probability Density Function of the Standard Normal Distribution

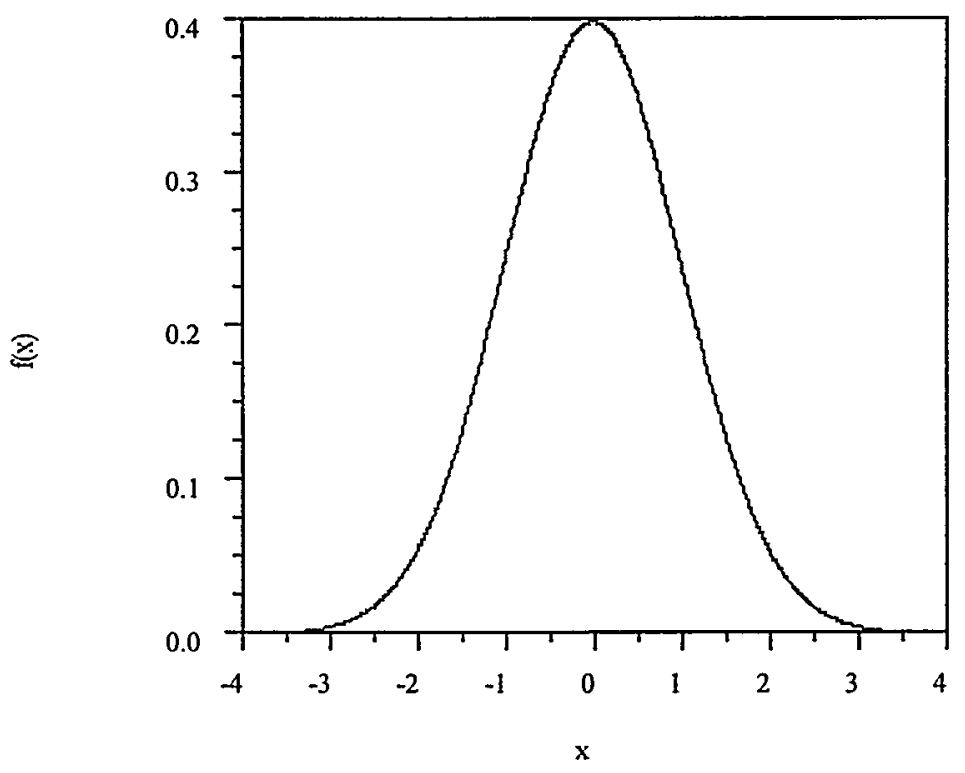

Figure 1b. Probability Density Function of the Standard Lognormal Distribution

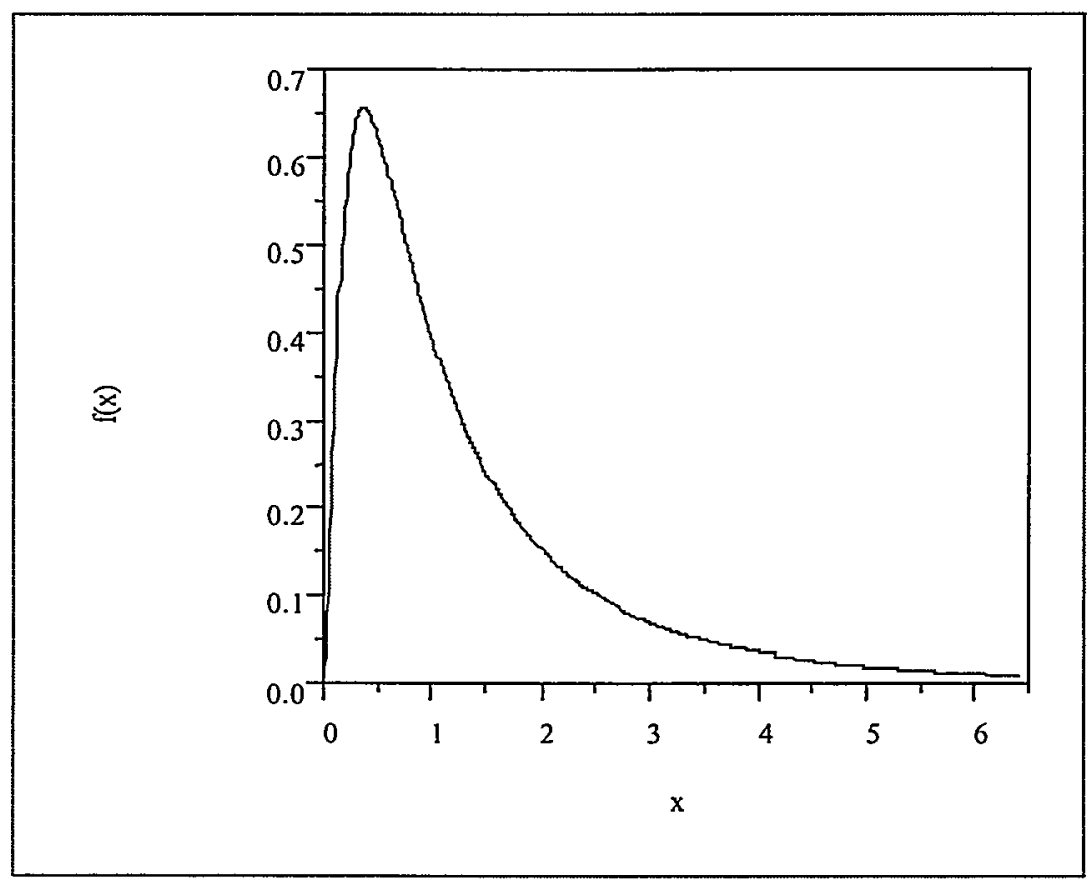

Rev. 0 
Figure 2a. Probability Density Function of the Symmetric Triangular Distribution in the Interval $[-1,1]$

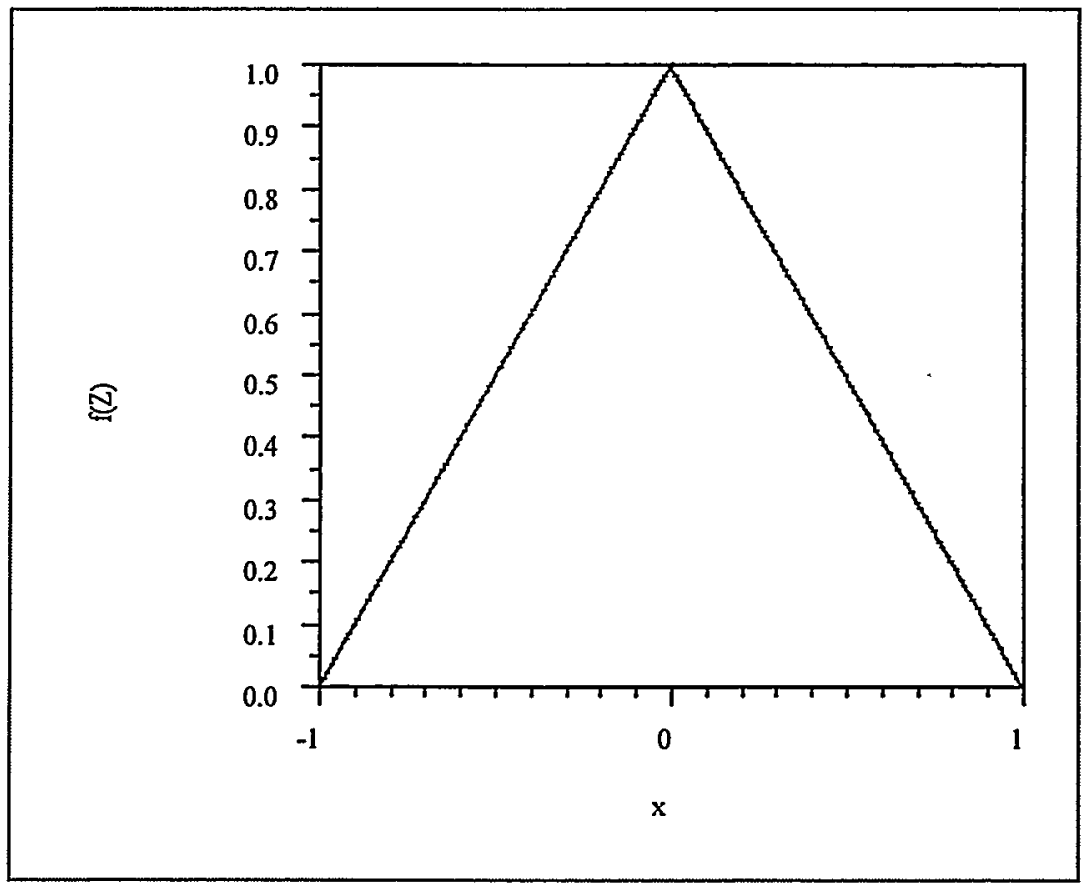

Figure 2b. Probability Density Function of the Standard Logtriangular Distribution

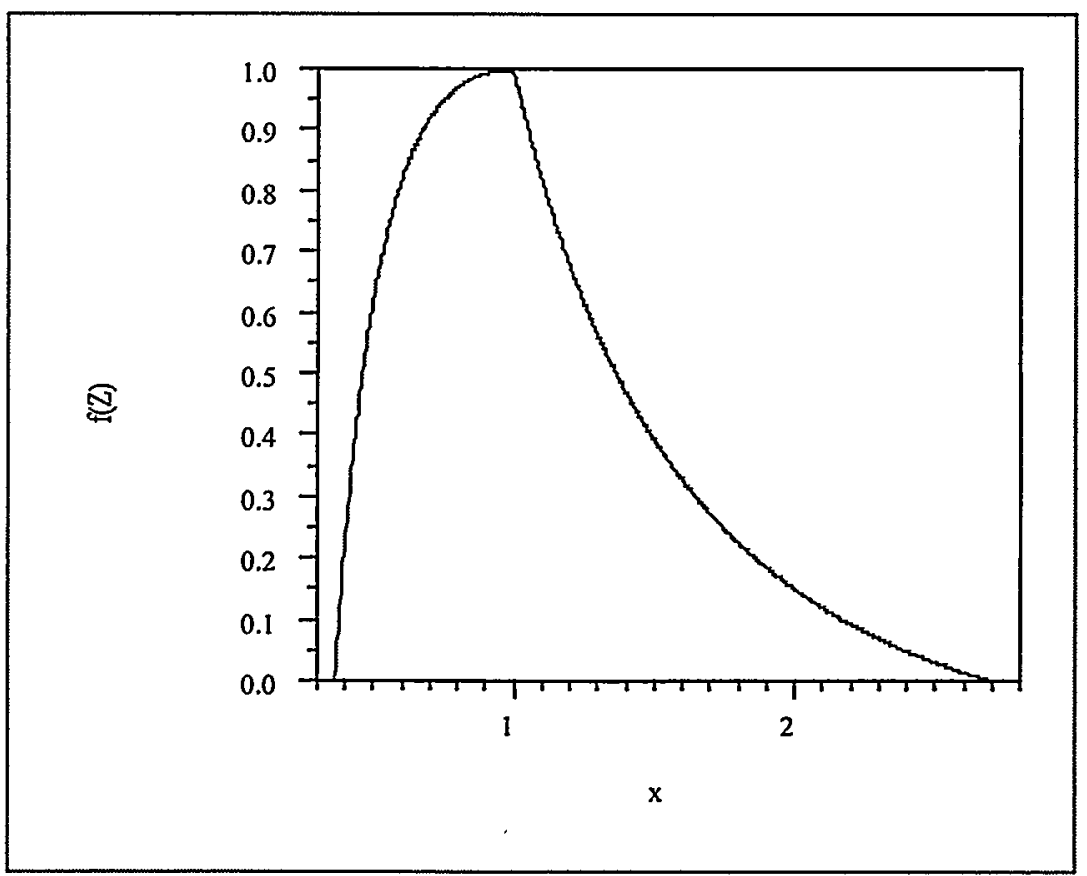

Rev. 0 
THIS PAGE INTENTIONALLY LEFT BLANK

Rev. 0 


\subsection{Condition 3}

Source Term/Inventory - Provide a complete source term for the composite analysis to include a complete inventory of the Upper Three Runs watershed and a reanalysis of the source term that was arbitrarily assigned to $C s$ and $S r$ to provide a more realistic radionuclide distribution.

\subsection{Complete Inventory of Upper Three Runs Watershed}

Residual radioactivity left in the A and $M$ areas of SRS will eventually migrate through the groundwater pathway and discharge to Tims Branch, and on to UTR and the Savannah River. A study to estimate the magnitude of these impacts was undertaken to place an upper bound on them.

Three major facilities could contribute residual radioactivity in future times, the closed M-Area Seepage Basin and Lost Lake complex, the Savannah River Laboratory (SRL) Seepage Basins, and the Savannah River Technology Center (SRTC) facility. The M-Area facilities were analyzed as part of the site-wide Environmental Impact Statement on Waste Management Activities and Groundwater Protection. The SRL Basins and the SRTC facility were analyzed using the PATHRAE code to calculate releases and environmental concentrations of radionuclides. The results are summarized in Table 3.1-1.

The M-Area results are taken directly from the M-Area Environmental Information Document (Pickett et al., 1987), using the "No Waste Removal and Closure" option, which most closely describes the actual actions taken at the seepage basin and Lost Lake. The SRL Basin model used the residual inventory remaining after the most contaminated upper one foot has been removed. The basins were assumed to be backfilled with 3 meters of material. No low permeability cap was assumed. The SRTC model assumed that the residual contamination was contained on a 1 meter thick concrete slab with the dimensions of the central corridor of the 773-A building (i.e., it was assumed that the radionuclides were concentrated into a smaller area than that of the entire building).

The former processing buildings in $\mathrm{M}$ Area (313-M, 320-M, and 321-M) were thoroughly surveyed and cleaned in preparation for privatization of the buildings. Estimates from surveys conducted as part of the preparation indicate that at most a few kilograms of uranium remain in the buildings. Because this low inventory is associated with the concrete structure, it would be modeled using a solubility limit, thus producing an extremely low source term. Comparison with the results from $247-\mathrm{F}$, which has a much higher inventory of enriched uranium, indicates that the M-Area process buildings would have been screened out and no further calculations would have been performed. Therefore, the process buildings were not analyzed further in this calculation.

The M-Area waste tanks that contained electroplating waste from the processing facilities are now inactive. All of the waste has been removed and vitrified for disposal as mixed waste. The disposal facility has not yet been determined; SRS has no plans to dispose of mixed waste. The tanks have been cleaned and are awaiting final disposition. Since the tanks are above-ground, it is expected that they will be removed and excessed as scrap metal. Therefore, neither the waste tanks nor the vitrified waste was analyzed further in this calculation. If the disposition of the tanks or vitrified waste changes, the change will be addressed per the Maintenance Program for the E-Area Vaults and Saltstone Performance Assessments, and the Composite Analysis (Attachment 1). 
Table 3.1-1 Estimated Peak Concentrations and Peak Times from A and M Areas

\begin{tabular}{|c|c|c|c|}
\hline Radionuclide & $\begin{array}{c}\text { Tims Branch } \\
\text { Peak Concentration } \\
\left(\mathrm{Ci} / \mathrm{m}^{3}\right)\end{array}$ & $\begin{array}{c}\text { Upper Three Runs } \\
\text { Peak Concentration } \\
\left(\mathrm{Ci} / \mathrm{m}^{3}\right)\end{array}$ & $\begin{array}{c}\text { Time of Peak } \\
\text { Concentration }(\mathrm{yr})\end{array}$ \\
\hline \multicolumn{4}{|l|}{ M Area Facilities } \\
\hline${ }^{238} \mathrm{U}$ & $4.4 \times 10^{-15}$ & $8.6 \times 10^{-17}$ & 186 \\
\hline \multicolumn{4}{|l|}{ SRL Basins } \\
\hline${ }^{239} \mathrm{Pu}$ & $3.5 \times 10^{-13}$ & $6.8 \times 10^{-15}$ & 36,000 \\
\hline${ }^{240} \mathrm{Pu}$ & $2.2 \times 10^{-14}$ & $4.3 \times 10^{-16}$ & 36,000 \\
\hline${ }^{234} \mathrm{U}$ & $1.9 \times 10^{-12}$ & $3.7 \times 10^{-14}$ & 12,700 \\
\hline${ }^{235} \mathrm{U}$ & $2.2 \times 10^{-13}$ & $4.3 \times 10^{-15}$ & 12,700 \\
\hline${ }^{238} \mathrm{U}$ & $2.6 \times 10^{-12}$ & $5.1 \times 10^{-14}$ & 12,700 \\
\hline \multicolumn{4}{|l|}{$\underline{\text { SRTC }}$} \\
\hline${ }^{3} \mathrm{H}$ & $1.2 \times 10^{-10}$ & $2.4 \times 10^{-12}$ & 120 \\
\hline${ }^{235} \mathrm{U}$ & $2.8 \times 10^{-16}$ & $5.5 \times 10^{-18}$ & 2,500 \\
\hline${ }^{238} \mathrm{U}$ & $1.6 \times 10^{-14}$ & $3.1 \times 10^{-16}$ & 2,500 \\
\hline${ }^{237} \mathrm{~Np}$ & $2.8 \times 10^{-15}$ & $5.5 \times 10^{-17}$ & 3,200 \\
\hline${ }^{239} \mathrm{Pu}$ & $7.7 \times 10^{-13}$ & $1.5 \times 10^{-14}$ & 52,000 \\
\hline${ }^{240} \mathrm{Pu}$ & $3.8 \times 10^{-15}$ & $7.4 \times 10^{-17}$ & 49,000 \\
\hline${ }^{242} \mathrm{Pu}$ & $7.9 \times 10^{-16}$ & $1.6 \times 10^{-17}$ & 55,000 \\
\hline
\end{tabular}


Comparison of the results in the table with the results for UTR in Table 5.3-2 in the CA shows that the contribution to UTR from A and M Areas is many orders of magnitude less than the contribution from the GSA.

\subsection{Reanalysis of the Source Term that was Arbitrarily Assigned to Cs and Sr}

Facilities where the inventory was attributed to only ${ }^{137} \mathrm{Cs}$ or ${ }^{90} \mathrm{Sr}$ were reformulated using the fission product distribution table in Stewart (Stewart 1985). This resulted in additional entries in Tables 4.4-2 and 4.4-5 in the CA. The revised tables are included here (the tables have the same table numbers as in the $\mathrm{CA}$ ). The result is that in a few cases, additional radionuclide sources would not have been screened out. In some cases the recalculated inventory produced fluxes to the water table greater that the screening value of $1 \times 10^{-4} \mathrm{Ci} / \mathrm{year}$. The additional sources are ${ }^{79} \mathrm{Se}$ in the H-Area Sand Filter, the F-Area Sand Filter and the spills at Tanks 16,37 and $8,{ }^{90} \mathrm{Sr}$ at the H-Area Sand Filter, and the spills at Tanks 13, 9, 16, 37, and B281-F, ${ }^{99} \mathrm{Tc}$ at all of the Solvent Tanks, the H-Area Sand Filter, the F-Area Sand Filter and the spills at Tanks 13,16, 37, and 8 , and ${ }^{129} \mathrm{I}$ at the H-Area Sand Filter, the F-Area Sand Filter, and the spills at Tanks 13, 16, 37 , and 8 .

The magnitude of the flux to the water table results for the radionuclides and facilities listed above are less than others that were analyzed and yielded low overall impacts. The conclusion of this supplemental work is that the omission of these sources did not affect the doses presented in the CA. 
Table 4.4-2 Residual Radionuclide Summary

\begin{tabular}{|c|c|c|c|c|c|c|c|c|c|c|c|c|c|c|}
\hline & & \multicolumn{13}{|c|}{ EArea } \\
\hline & & Lysimotors & \multicolumn{2}{|c|}{ MWMF } & $\begin{array}{c}\text { Naval Fual } \\
\text { Wasto }\end{array}$ & $\begin{array}{c}\text { Naval } \\
\text { Roactors KAPL } \\
\text { CBIS }\end{array}$ & $\begin{array}{c}\text { Naval } \\
\text { Fonctors KAPS } \\
\text { Hond }\end{array}$ & $\begin{array}{c}\text { Old Burial } \\
\text { around }\end{array}$ & $\begin{array}{c}\text { Old Solvent } \\
\text { Tanks S1-S22 }\end{array}$ & $\begin{array}{c}\text { Sahstono } \\
\text { Lyskmoters }\end{array}$ & Sitt Tronchos & $\begin{array}{c}\text { Solvont Tanks } \\
\text { S23-530 and } \\
\text { 532 }\end{array}$ & Vauths LAW & Vauth ILV \\
\hline \multicolumn{2}{|c|}{ Bullding Numbor } & $643-7 E$ & \multicolumn{2}{|c|}{ 643.7E and $643.28 \mathrm{E}$} & 643-7E & $643.7 \mathrm{E}$ & B43.7E & 643-E & 643-E & $643.7 \mathrm{E}$ & 643.7E & $643.7 \mathrm{E}$ & 661-6E & 662-6E \\
\hline \multirow{2}{*}{\multicolumn{2}{|c|}{$\begin{array}{l}\text { Sho Map Pago No. } \\
\text { Datos of Oporatlon }\end{array}$}} & 10 & \multicolumn{2}{|c|}{$10,1 \cdot 3$} & $\begin{array}{c}10, G-12 \text { and } \\
G .13\end{array}$ & 12.8-10 & $12.8 \cdot 10$ & $10, A-12$ & 10 & 10 & 10 & 10 & 10 & 10 \\
\hline & & $1978 \cdot 1980$ & 1972 - 1988 & $1988-1896$ & 1889 & 1994.2014 & \begin{tabular}{|l|}
$1994-2014$ \\
\end{tabular} & $1952 \cdot 1972$ & \begin{tabular}{|l|}
1955 - 1081 \\
\end{tabular} & 1983 & 1995 -2015 & 1981.1997 & $1995 \cdot 2015$ & $1995-2015$ \\
\hline \multicolumn{2}{|c|}{ Total Volumo } & DU & DU & DU & $41.9 \mathrm{Kg}$ & DU & DU & DU & DU & 7500 gal & $26000 \mathrm{~m}^{3}$ & DU & $34000 \mathrm{~m}^{2}$ & $7464 m^{3}$ \\
\hline \multicolumn{2}{|c|}{ Roforonco No. } & 8.22, 8.49 & B.19, B-42 & B.10, B-A9 & 8.40 & B.20 & 8.28 & B.916 & B.28 & 0.24 & $8+0,6,62$ & B.39 & 8.05 & 8.32 \\
\hline & $\mathrm{H} \cdot 3$ & - & $2.06 \mathrm{E}+06$ & $2.34 E+05$ & $=$ & $4.32 E+02$ & $6.67 E-04$ & $2.12 E+06$ & & 7.39E-01 & $8.75 E+\infty 0$ & - & $1.66 \mathrm{E}+06$ & $8.80 E+05$ \\
\hline & $c-14$ & $1.75 E+\infty 0$ & $1.86 \mathrm{E}+03$ & $1.86 E+03$ & $\ldots$ & $4.33 E+02$ & $1.49 E+\infty$ & $3.09 E+03$ & - & $2.59 \mathrm{E}-04$ & $\bar{*}$ & $=$ & $1.70 E \cdot 01$ & $2.24 E-03$ \\
\hline & Na.22 & $1.02 E-03$ & 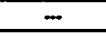 & - & $\ldots$ & $=$ & $=$ & - & $\ldots$ & - & - & - & - & $\ldots$ \\
\hline & A1.26 & $\cdots$ & 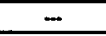 & - & $-\cdots$ & - & 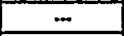 & - & $=$ & $\overline{-}$ & $=$ & $=$ & $=$ & 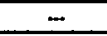 \\
\hline & $K \rightarrow 0$ & 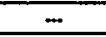 & $=$ & - & - & - & - & $\overline{-}$ & - & $=$ & - & - & - & $=$ \\
\hline & Sce-46 & $3.50 E-02$ & - & $\ldots$ & $\ldots$ & - & $\ldots$ & $\ldots$ & $=$ & $\ldots$ & $\overline{-}$ & $=$ & - & 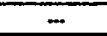 \\
\hline & C..51 & $=$ & - & $-\cdots$ & $=$ & $2.40 E+04$ & $3.74 E+01$ & $\ldots$ & - & - & - & - & - & $\ldots$ \\
\hline & $M_{n} \cdot 54$ & $2.19 E-01$ & $2.62 E+01$ & $1.20 \mathrm{E}+00$ & - & $4.39 \mathrm{E}+03$ & $1.49 E+01$ & $5.59 E+01$ & - & - & - & - & - & $=$ \\
\hline & Fo. 55 & - & $\ldots$ & - & - & $2.88 \mathrm{E}+05$ & $2.98 \mathrm{E}+02$ & .. & $\ldots$ & - & $\ldots$ & $\ldots$ & - & $\ldots$ \\
\hline & Fo.59 & $\cdots$ & - & $\because$ & $\ldots$ & $2.40 E+04$ & $3.73 E+01$ & $\ldots$ & $=$ & - & $=$ & - & - & $\ldots$ \\
\hline R & 0.57 & $2.12 E+\infty 0$ & - & - & - & - & - & $\cdots$ & - & - & - & $\ldots$ & $\ldots$ & 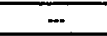 \\
\hline A & Co.58 & - & $\ldots$ & $\cdots$ & $\ldots$ & $6.50 \mathrm{E}+04$ & $5.94 \mathrm{E}+02$ & - & $\ldots$ & - & $-\cdots$ & $\ldots$ & - & $\ldots$ \\
\hline D & 0.60 & $2.94 \mathrm{E}+00$ & $1.88 \mathrm{E}+06$ & $7.18 E+04$ & $\cdots$ & $3.14 E+05$ & $1.49 \mathrm{E}+02$ & $1.60 E+06$ & $\ldots$ & $7.96 \mathrm{E}-03$ & $4.63 E-02$ & $\ldots$ & $8.66 \mathrm{E}+\infty 0$ & $1,38 E+01$ \\
\hline 1 & N-59 & - & $1.74 E+03$ & $7.96 \mathrm{E}+01$ & - & $4.89 E+03$ & $4.46 \mathrm{E}-01$ & $3.71 E+03$ & - & $7.67 E-06$ & - & - & $1.06 \mathrm{E}-01$ & $5.66 \mathrm{E}-02$ \\
\hline o & $N-63$ & - & $2.37 E+05$ & $1.09 E+04$ & $\ldots$ & $5.76 E+05$ & $4.46 E+01$ & $5.06 E+05$ & $\ldots$ & $7.67 E-04$ & - & - & - & $=$ \\
\hline $\mathrm{N}$ & $2 n-65$ & $2.60 \mathrm{E}+00$ & $\ldots$ & - & $\ldots$ & - & - & - & - & - & - & $\ldots$ & $=$ & - \\
\hline u & 50.79 & $\cdots$ & 1.07E-01 & $6.66 \mathrm{E}-03$ & - & $3.94 E-03$ & $2.23 E-07$ & $7.21 \mathrm{E}-01$ & $5,11 E-05$ & $1.25 E-02$ & $=$ & $2.09 E-05$ & $2.85 E-02$ & $6.46 \mathrm{E}-03$ \\
\hline c & Sr.89 & $\cdots$ & $\ldots$ & $\cdots$ & $\ldots$ & - & - & -- & $\ldots$ & -- & $\cdots$ & $\ldots$ & - & $\cdots$ \\
\hline L & Sr.90 & $3.93 \mathrm{E}-02$ & $1.81 E+04$ & $1.02 E+03$ & - & $1.69 E+01$ & $5.94 \mathrm{E}-02$ & $1.10 E+05$ & $7.80 E+00$ & $2.64 E-02$ & $2.88 \mathrm{E}-01$ & $3.19 E+00$ & $1.00 \mathrm{E}+02$ & $1.47 E+04$ \\
\hline 1 & $Y .90$ & $\cdots$ & - & $\cdots$ & $\ldots$ & $1.69 \mathrm{E}+01$ & $5.94 \mathrm{E}-02$ & $=$ & $\ldots$ & $=$ & 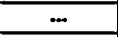 & $\ldots$ & $7.63 \mathrm{E}+01$ & $\because$ \\
\hline D & $2 \mathrm{zr} \cdot 93$ & 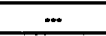 & 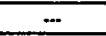 & $=$ & $\ldots$ & $2.40 E+04$ & $2.98 \mathrm{E}-04$ & 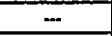 & $2.43 \mathrm{E}-04$ & $1.02 E-05$ & 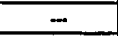 & $9.84 E-05$ & $1.16 \mathrm{E}-05$ & $\ldots$ \\
\hline \multirow[t]{15}{*}{ E } & $2 \pi \cdot 95$ & $7.99 E-01$ & $\cdots$ & $\ldots$ & - & $1.98 E+05$ & $1.49 E+01$ & 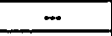 & $\cdots$ & $=$ & - & - & $\cdots$ & $\cdots$ \\
\hline & $\mathrm{Nb} \cdot 93 \mathrm{~m}$ & 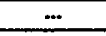 & $\cdots$ & $\ldots$ & - & $2.40 E+04$ & $2.23 E+00$ & - & -- & $\cdots$ & $\ldots$ & - & - & $\ldots$ \\
\hline & \begin{tabular}{|l|}
$\mathrm{Nb}-84$ \\
\end{tabular} & - & $\cdots$ & - & - & $2.00 E+01$ & $2.88 E-02$ & - & $\ldots$ & - & - & - & - & $\cdots$ \\
\hline & Nb-95 & $1.02 E+00$ & $\ldots$ & $\ldots$ & $=$ & $4.19 E+05$ & $3.20 \mathrm{E}+01$ & - & $\cdots$ & $\cdots$ & - & $\approx$ & $=$ & $\ldots$ \\
\hline & $\mathrm{Nb} \cdot 95 \mathrm{~m}$ & - & $\ldots$ & $\ldots$ & $\cdots$ & $4.19 E+03$ & - & - & - & 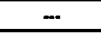 & - & $-\cdots$ & $\cdots$ & $\ldots$ \\
\hline & Mo.93 & - & $\cdots$ & $\cdots$ & - & $4.61 E+\infty 0$ & $-\cdots$ & $\cdots$ & $\cdots$ & $\cdots$ & - & $\ldots$ & $\cdots$ & $\ldots$ \\
\hline & \begin{tabular}{|c|}
$T c-99$ \\
\end{tabular} & $\because$ & $3.83 \mathrm{E}+\infty 0$ & $2.39 \mathrm{E}-01$ & - & $4.58 E-01$ & $1.49 \mathrm{E}-03$ & $2.59 \mathrm{E}+01$ & $1.83 \mathrm{E}-03$ & $2.53 \mathrm{E}+00$ & $9.73 E-04$ & $7.52 E-04$ & $3.41 E-02$ & 2.18E-01 \\
\hline & Ru-103 & $4.14 E-01$ & $\ldots$ & $\ldots$ & - & 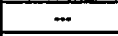 & - & - & - & - & $=$ & - & $\cdots$ & 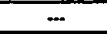 \\
\hline & Ru-106 & $1.12 E+\infty 0$ & $\cdots$ & $=$ & $\cdots$ & $1.34 E+\infty$ & $\ldots$ & $\ldots$ & $7.07 \mathrm{E}-02$ & $1.28 E+\infty$ & - & $2.89 \mathrm{E}-02$ & $1.66 \mathrm{E}-01$ & $\ldots$ \\
\hline & Rh-108 & - & $\ldots$ & $\cdots$ & $-\cdots$ & $\ldots$ & - & 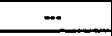 & - & - & $\ldots$ & - & $6.89 E-04$ & $\cdots$ \\
\hline & $P d-107$ & $\therefore$ & $\ldots$ & $\ldots$ & $-\overline{-}$ & $-\overline{-}$ & $=$ & 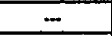 & $1.41 E-05$ & $7.67 E-07$ & $=$ & $5.78 E-06$ & - & $\approx$ \\
\hline & $A_{g}-110 m$ & - & $\cdots$ & - & $-\cdots$ & - & - & $=$ & $2.18 \mathrm{E}-05$ & $2.27 E-05$ & $=$ & $8.94 E-06$ & - & $=$ \\
\hline & $m-113 m$ & - & $\ldots$ & - & $\cdots$ & $1.56 \mathrm{E}+04$ & $=$ & $=$ & - & - & $=$ & - & $=$ & $\ldots$ \\
\hline & Sn-113 & - & - & - & - & $1.56 E+04$ & - & $=$ & - & - & - & - & $=$ & - \\
\hline & Sn-119m & $=$ & $=$ & $=$ & - & $2.60 E+05$ & - & - & - & - & - & - & - & - \\
\hline
\end{tabular}




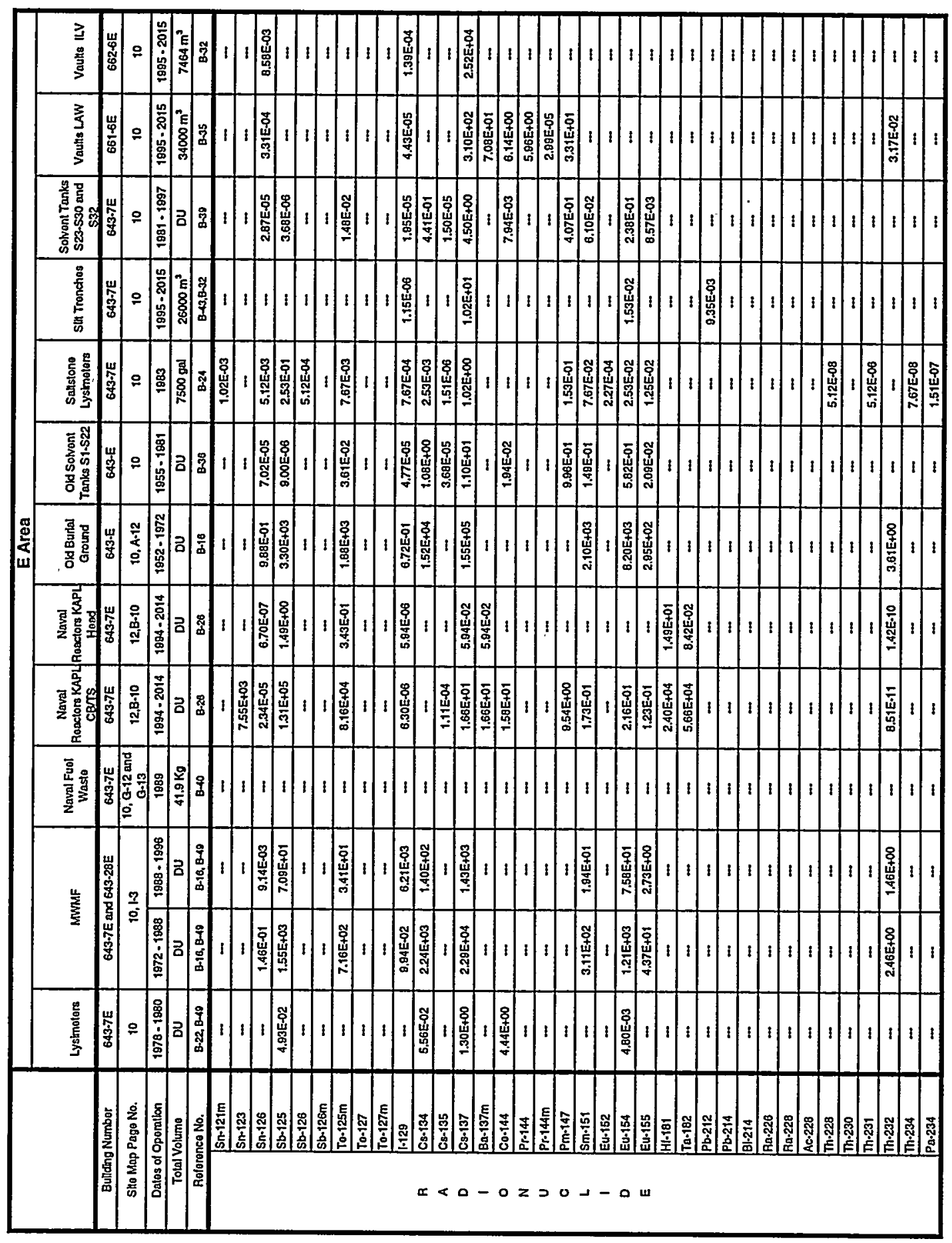




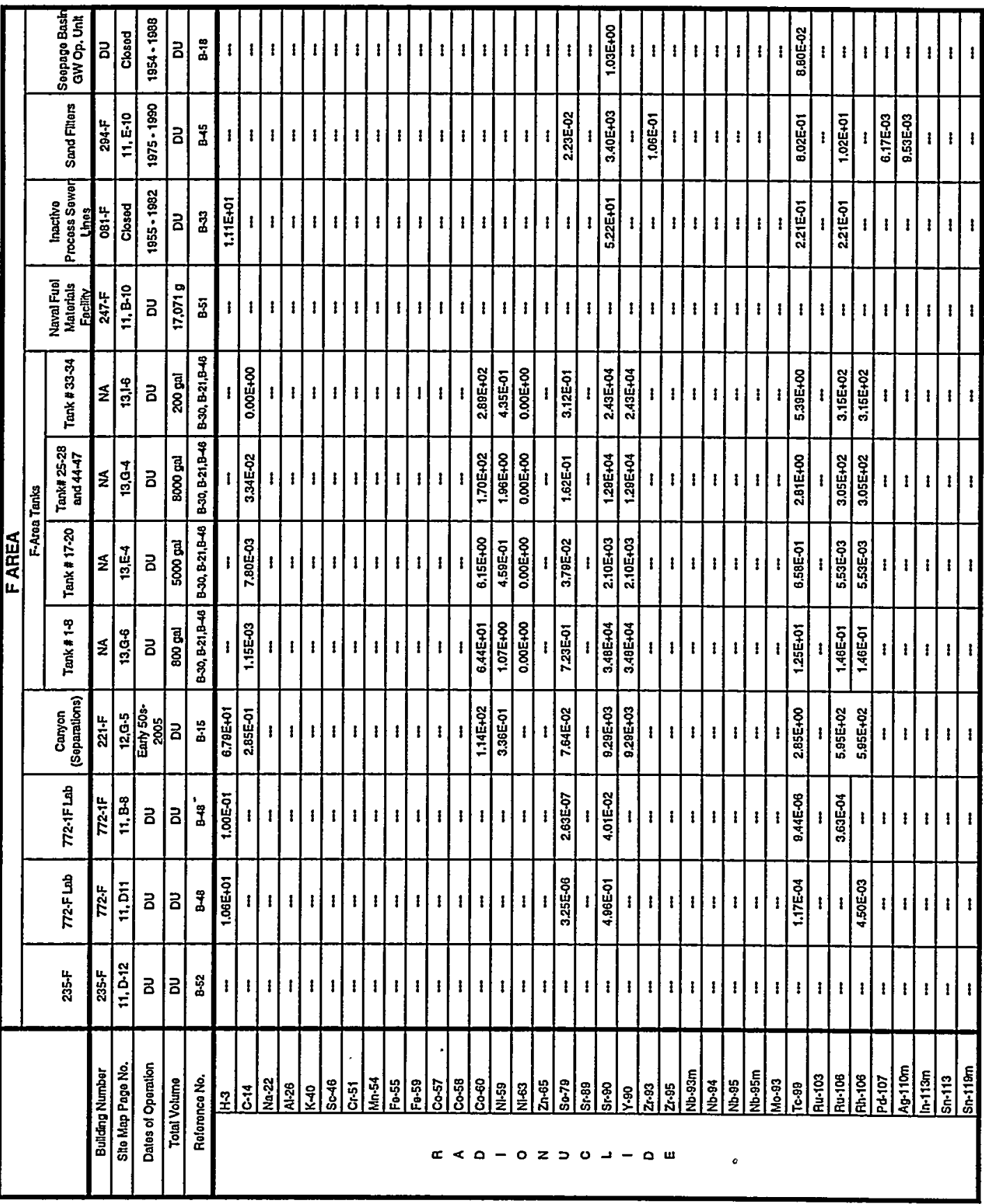


Table 4.4-2 Residual Radionuclide Summary

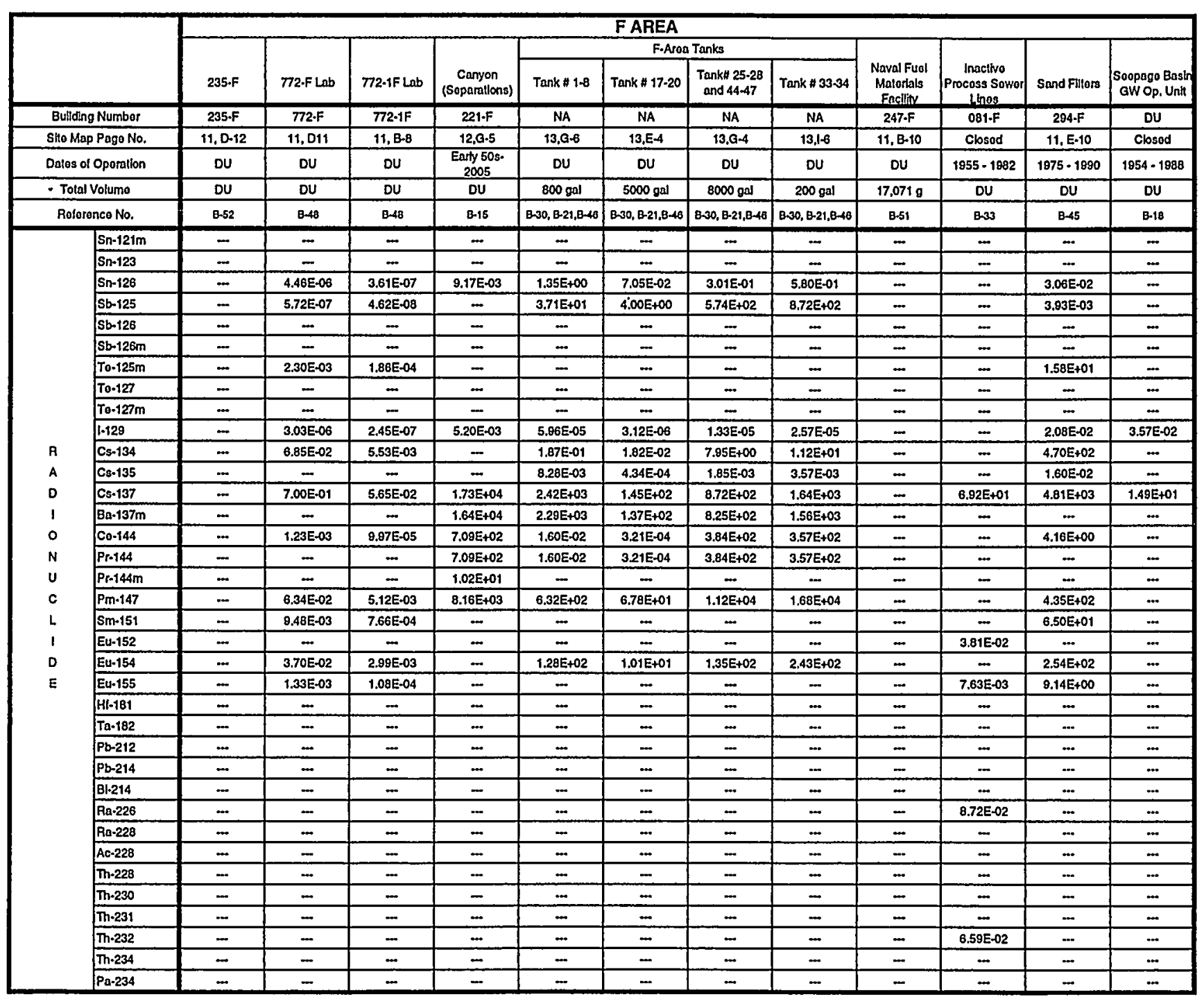




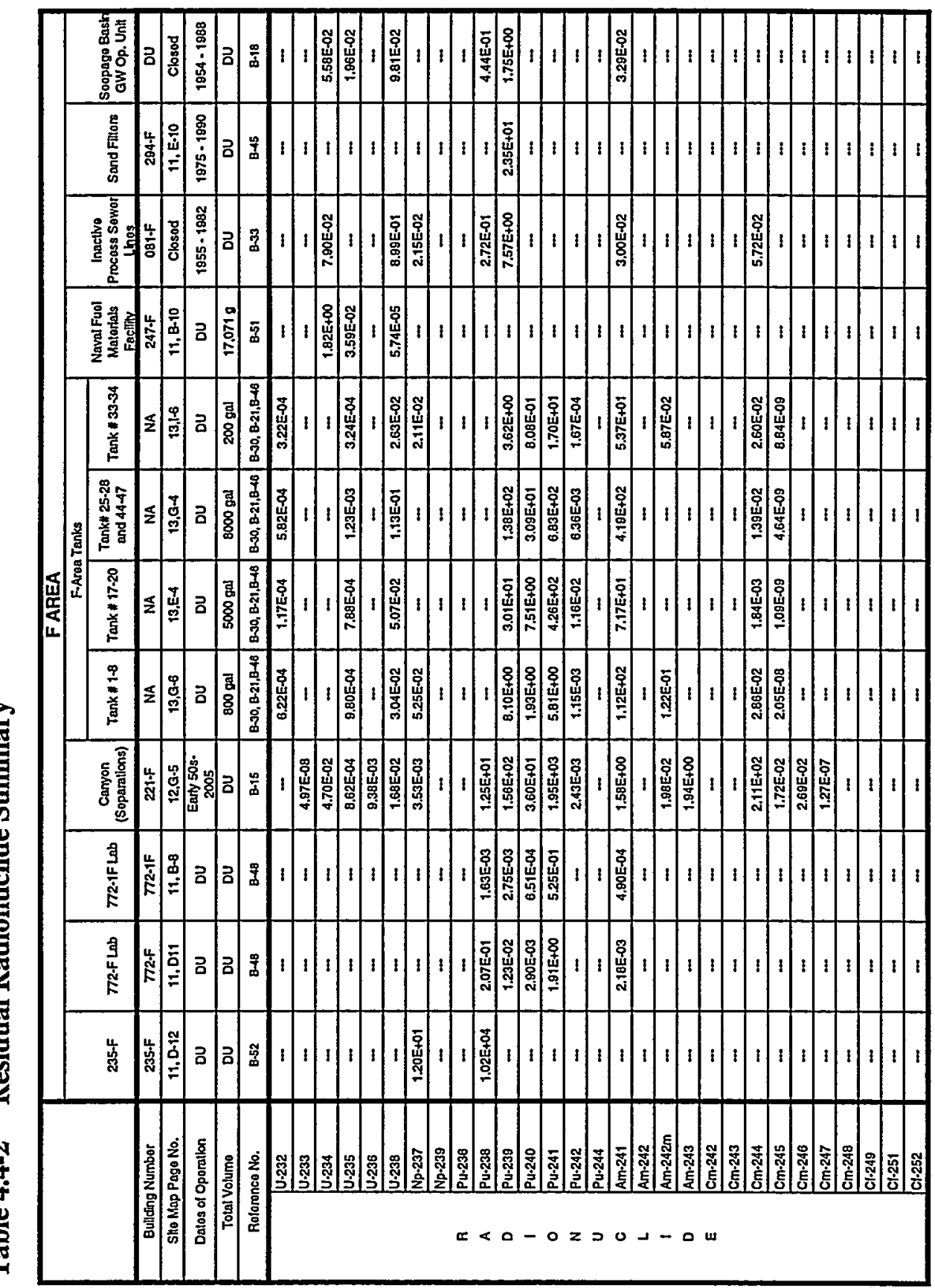

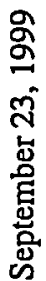


Table 4.4-2 Residual Radionuclide Summary

\begin{tabular}{|c|c|c|c|c|c|c|c|c|c|c|c|c|c|c|c|c|}
\hline & & \multicolumn{12}{|c|}{ HAREA } & \multicolumn{2}{|c|}{ S Area } & \multirow{3}{*}{$\begin{array}{c}\text { Z Area } \\
\text { Sallstono } \\
\text { Vaults }\end{array}$} \\
\hline & & \multirow[b]{2}{*}{$\begin{array}{c}\text { Canyon } \\
\text { (Soparallons) } \\
\end{array}$} & \multirow[b]{2}{*}{$\begin{array}{c}\text { ETF Rocoipt } \\
\text { Tank }\end{array}$} & \multirow[b]{2}{*}{$\begin{array}{c}\text { Inactlvo } \\
\text { Procoss Sowor } \\
\text { Unos }\end{array}$} & \multicolumn{5}{|c|}{ H-Aroa Tenks } & \multirow[b]{2}{*}{$\begin{array}{c}\text { Now Solvont } \\
\text { Tanks } \\
\text { H33.H3B }\end{array}$} & \multirow[b]{2}{*}{ Sand Filtor } & \multirow[b]{2}{*}{$\mid \begin{array}{l}\text { Soopago Bastn } \\
\text { GW Op. Unitt }\end{array}$} & \multirow[b]{2}{*}{$\begin{array}{c}\text { Trthum } \\
\text { Procossling } \\
\end{array}$} & \multirow[b]{2}{*}{ DWPF } & \multirow[b]{2}{*}{$\begin{array}{l}\text { Low Poinl } \\
\text { Pump PH }\end{array}$} & \\
\hline & & & & & Tank $* \mathbf{9 . 1 2}$ & Tank $\# 13-16$ & $\begin{array}{c}\text { Tank \# 21-24, } \\
29.32 \text {, and } \\
35.37\end{array}$ & $\operatorname{Tan} x=38-43$ & Tank \& 48.51 & & & & & & & \\
\hline \multicolumn{2}{|c|}{ Buldding Numbor } & $221 \cdot H$ & $241 \cdot H$ & $081 \cdot \mathrm{H}$ & NA & NA & NA & NA & NA & DU & $294-H$ & Du & $232 \mathrm{H}, 233 \mathrm{H}, 23 \mathrm{H}$ & 292.5 & 511.5 & $45 t-1,6,7$ \\
\hline \multicolumn{2}{|c|}{ SHo Map Pago No. } & $15, F=5$ & $\begin{array}{c}16, F-8, \\
11\end{array}$ & Closod & $16, F-12$ & 17,A-5 & 14,F- -6 & $14, \mathrm{H}-\mathrm{g}$ & $14,1-9$ & $14,0 \cdot 12$ & $15, H-10$ & Closod & $15, \mathrm{c} \cdot \mathrm{A}$ & $19, F=4$ & 19, N.5 & $20,6.8$ \\
\hline \multicolumn{2}{|c|}{ Dates of Oporation } & Earty 50s- 2005 & 1977. Prosont & 1955.1982 & DU & DU & DU & DU & DU & $1997-2028$ & 1975 - 1990 & $1954 \cdot 1888$ & 1955 - 2005 & $1088 \cdot 2039$ & 1996-2038 & $1992 \cdot 2038$ \\
\hline \multicolumn{2}{|c|}{ Total Volumo } & DU & $1000 \mathrm{~L}$ & DU & $400 \mathrm{gal}$ & $400 \mathrm{gal}$ & $2000 \mathrm{gal}$ & $600 \mathrm{gal}$ & $1300 \mathrm{gal}$ & DU & DU & DU & DU & $1000 \mathrm{gal}$ & $50 \mathrm{gal}$ & DU \\
\hline \multicolumn{2}{|c|}{ Roforonco No. } & 8.45 & $8+2$ & 8.33 & $\mathrm{~B} 30, \mathrm{~B}-21, \mathrm{~B}-\mathrm{B}$ & $8-30,8 \cdot 21,8-8$ & $B \cdot 30,8 \cdot 21,8+8$ & $8: 30,0 \cdot 21,8-16$ & $\mathrm{~B} \sim 0, \mathrm{~B}-21, \mathrm{~B}-\mathrm{B}$ & B.39 & BA5 & 8.18 & 8.17 & $B+1$ & $B+1$ & B.23 \\
\hline & $\mathrm{H} \cdot 3$ & $1.02 E+00$ & $7.00 \mathrm{E}-02$ & $2.87 E+01$ & - & $=$ & - & - & - & $=$ & - & - & $3.00 E+04$ & $0.34 E-02$ & $3.17 E-03$ & $1.00 E+04$ \\
\hline & c.14 & $4.28 \mathrm{E}-03$ & - & - & 7.97E-04 & $2.80 E-04$ & $8.78 E-04$ & $5.85 E-04$ & $2.08 E-04$ & - & $=$ & - & - & 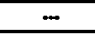 & - & $6.50 E+\infty$ \\
\hline & Na.22 & - & $=$ & - & - & - & - & - & - & - & - & - & - & $\cdots$ & - & - \\
\hline & Al-28 & - & - & - & - & - & - & - & $=$ & - & $=$ & - & -- & - & - & - \\
\hline & $K-40$ & - & $=$ & $=$ & - & - & - & - & $=$ & - & $=$ & - & - & - & - & $=$ \\
\hline & $5 e-46$ & - & - & $=$ & - & - & - & - & - & - & $=$ & - & - & - & $=$ & $=$ \\
\hline & C.r.51 & - & - & $=$ & - & - & - & - & $=$ & - & - & - & - & $=$ & $=$ & - \\
\hline & Mn:54 & - & - & - & - & - & - & - & $=$ & $=$ & - & - & $=$ & - & 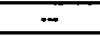 & - \\
\hline & F0.55 & $\ldots$ & - & $=$ & - & - & - & - & $=$ & $=$ & - & - & $=$ & - & - & - \\
\hline & $\longdiv { F 0 . 5 9 }$ & - & $=$ & $=$ & - & - & - & $=$ & - & - & - & $=$ & - & - & - & - \\
\hline R & Co.57 & - & - & - & - & - & $=$ & $=$ & - & - & $=$ & - & - & - & - & - \\
\hline A & $C 0.58$ & - & - & - & - & -- & - & - & - & - & - & - & - & - & - & - \\
\hline D & $\begin{array}{cc}0.60 \\
\end{array}$ & $1.71 E+\infty 0$ & $1.00 E-04$ & $5.15 E-01$ & $4.78 E+01$ & $2.47 E+01$ & $4.36 \mathrm{E}+02$ & $3.22 E+02$ & $7.10 E-08$ & - & - & $=$ & $=$ & $2.84 E+02$ & $1.47 E+01$ & $2.00 E+02$ \\
\hline 1 & \begin{tabular}{|l|}
$\mathrm{N} 1.59$ \\
\end{tabular} & $5.04 E-03$ & - & - & $5.30 E-01$ & 4.45E-01 & $8,87 E_{-01}$ & $4.02 E-01$ & $1.37 E-02$ & $=$ & - & - & - & $2.39 E+00$ & $1.20 \mathrm{E}-01$ & $2.00 E-01$ \\
\hline$\circ$ & $N \mid-63$ & - & - & - & - & - & - & $=$ & - & - & - & - & - & $2.97 E+02$ & $1.49 E+01$ & $2.00 E+01$ \\
\hline$N$ & $2 n-65$ & - & $=$ & - & - & - & $=$ & - & $=$ & - & - & - & - & $=$ & - & - \\
\hline u & 50.79 & $1.15 \mathrm{E}-03$ & - & - & $3.09 \mathrm{E}-01$ & $2.75 E-01$ & $5.10 \mathrm{E}-01$ & $2.31 E-01$ & $2.11 E-03$ & $1.86 E-04$ & $2.24 E-02$ & - & - & $2.34 E-01$ & $1.17 E-02$ & $3.20 E+02$ \\
\hline c & Sr.89 & - & - & - & - & - & - & - & - & - & 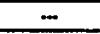 & $\approx$ & 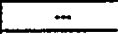 & - & - & - \\
\hline$L$ & Sr.90 & $1.39 E+02$ & $4.00 E-04$ & $1.84 E+01$ & $1.67 E+04$ & $1.40 E+04$ & $3.82 E+04$ & $2.08 E+04$ & $1.41 E+02$ & $2.64 E+01$ & $3.41 E+03$ & $5.35 E+01$ & $-\cdots$ & $5.17 \varepsilon+04$ & $2.59 E+03$ & $6.80 \mathrm{E}+02$ \\
\hline 1 & $\gamma=80$ & $1.39 E+02$ & - & - & $1.67 E+04$ & $1.40 E+04$ & $3.92 E+04$ & $2.08 E+04$ & $1.41 E+02$ & - & $=$ & $=$ & $=$ & $5.32 E+04$ & $2.66 \mathrm{E}+03$ & $=$ \\
\hline D & $2 \mathrm{r} \cdot 93$ & $=$ & - & - & - & - & - & - & - & $8.83 \mathrm{E}-04$ & $1.06 E_{0} 01$ & $=$ & - & $1.94 E+00$ & $0.70 E-02$ & $2.60 E-01$ \\
\hline E & Zr.95 & - & - & - & $=$ & $=$ & $=$ & $\cdots$ & - & - & - & - & - & $1.74 E-02$ & $8.70 E-04$ & $=$ \\
\hline & Nb-93m & $=$ & $=$ & - & - & $=$ & $=$ & - & $=$ & - & - & - & - & $=$ & - & $=$ \\
\hline & \begin{tabular}{|l|l}
$N \mathrm{Nb}-94$ \\
\end{tabular} & - & - & $=$ & - & $=$ & - & - & - & - & $=$ & $-\cdots$ & $=$ & $\ldots$ & - & 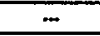 \\
\hline & \begin{tabular}{|l|l|}
$N b-95$ \\
\end{tabular} & - & $=$ & $\cdots$ & - & $\ldots$ & - & - & $=$ & $=$ & $\cdots$ & $\ldots$ & $=$ & 3.67E-02 & $8.84 E-03$ & - \\
\hline & Nb-95m & - & - & - & - & - & $\cdots$ & - & $=$ & - & - & $\cdots$ & $=$ & -- & $\ldots$ & - \\
\hline & \begin{tabular}{|l|l} 
Mo.93 \\
\end{tabular} & - & - & - & - & $=$ & - & $=$ & $=$ & $=$ & $\cdots$ & $\cdots$ & - & $\ldots$ & $\ldots$ & - \\
\hline & TC-99 & $4.28 E-02$ & - & - & $5.29 E+\infty 0$ & $4.70 E+\infty 0$ & $8.65 E+\infty$ & $3.92 E+\infty 0$ & $3.62 E-02$ & $6.68 \mathrm{E}-03$ & 8.04E-01 & $6.31 E-01$ & $\ldots$ & $4.26 E+\infty 00$ & $2.13 E-01$ & $0.50 E+04$ \\
\hline & Bu-103 & - & - & - & $=$ & $=$ & - & - & - & - & - & - & - & - & -- & - \\
\hline & Ru-106 & $8.92 \mathrm{E}+\infty 0$ & $5.00 E-03$ & - & $8.02 E-03$ & $4.76 E-04$ & $2,36 E+01$ & $4,63 E+01$ & $1.04 E-03$ & $2.57 E-01$ & $1.02 E+01$ & 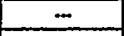 & - & $2.69 E+03$ & $1.35 \Xi+02$ & $3.30 E+04$ \\
\hline & $\mathrm{fr}-108$ & $8,82 \mathrm{E}+\infty 0$ & - & - & $8.02 E-03$ & $4.76 \mathrm{E}-04$ & $2,36 \mathrm{E}+01$ & $4,63 E+01$ & $1.04 E-03$ & - & $=$ & $=$ & $=$ & $2.64 E+03$ & $1.32 E+02$ & - \\
\hline & \begin{tabular}{|l|} 
Pd.107 \\
\end{tabular} & - & - & - & - & - & - & $=$ & - & $5.14 E-05$ & $6.18 E-03$ & $\cdots$ & - & $1.57 E-02$ & $7.85 E-04$ & $2.00 E-02$ \\
\hline & Ag-110m & - & - & - & $=$ & $=$ & $=$ & - & $\ldots$ & $7.94 E-05$ & $9.55 E-03$ & $=$ & - & $2.25 E+01$ & $1.13 E+\infty$ & $5.80 E-01$ \\
\hline & In-113m & - & $=$ & $=$ & - & - & - & - & - & - & - & - & $=$ & - & - & - \\
\hline & $5 n-113$ & $=$ & - & $=$ & $=$ & - & - & - & - & - & - & $=$ & - & $=$ & - & - \\
\hline & Sn-118m & - & - & - & $=$ & - & - & - & - & - & - & - & - & 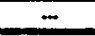 & - & - \\
\hline
\end{tabular}


Table 4.4-2 Residual Radionuclide Summary

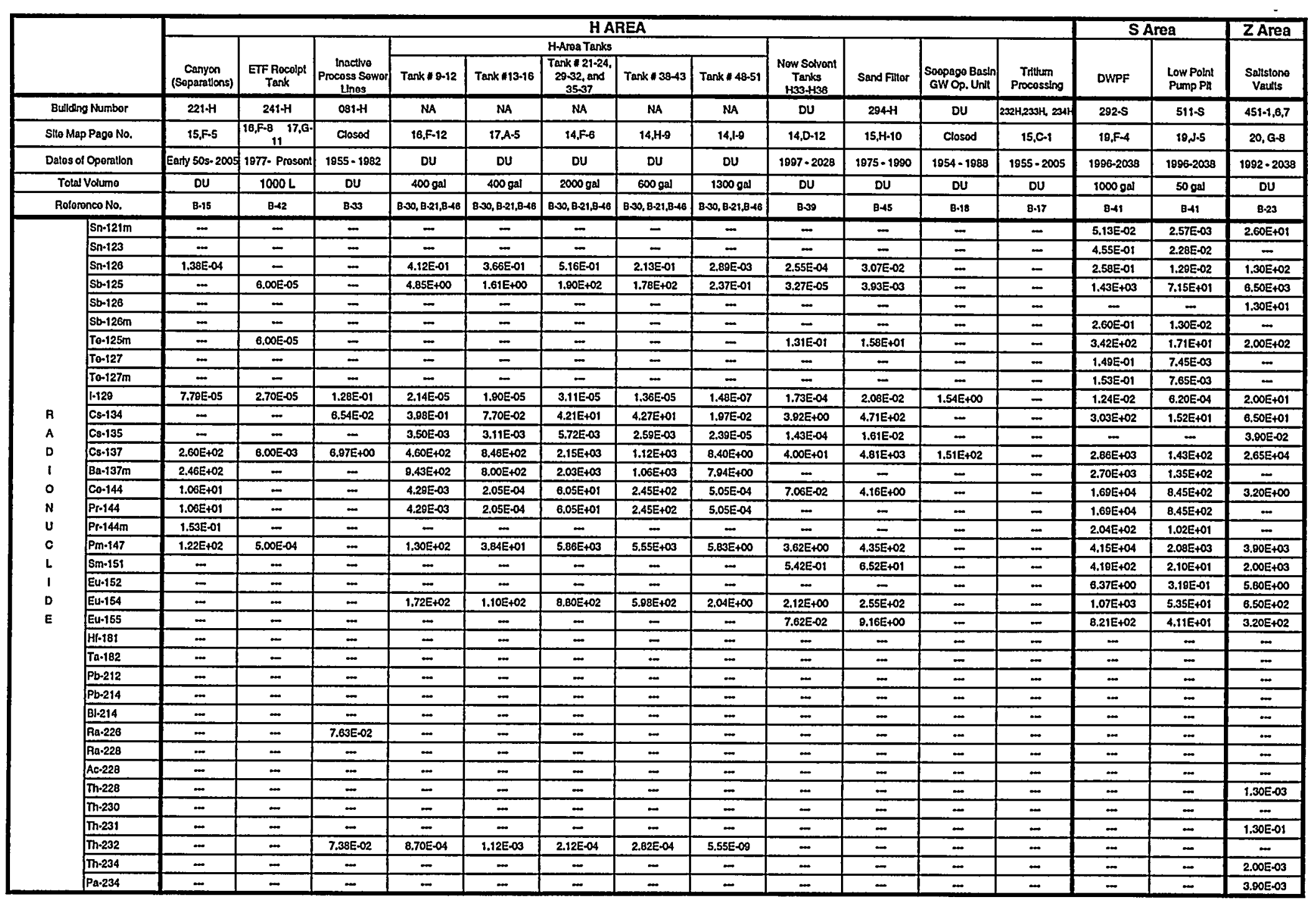


Table 4.4-2 Residual Radionuclide Summary

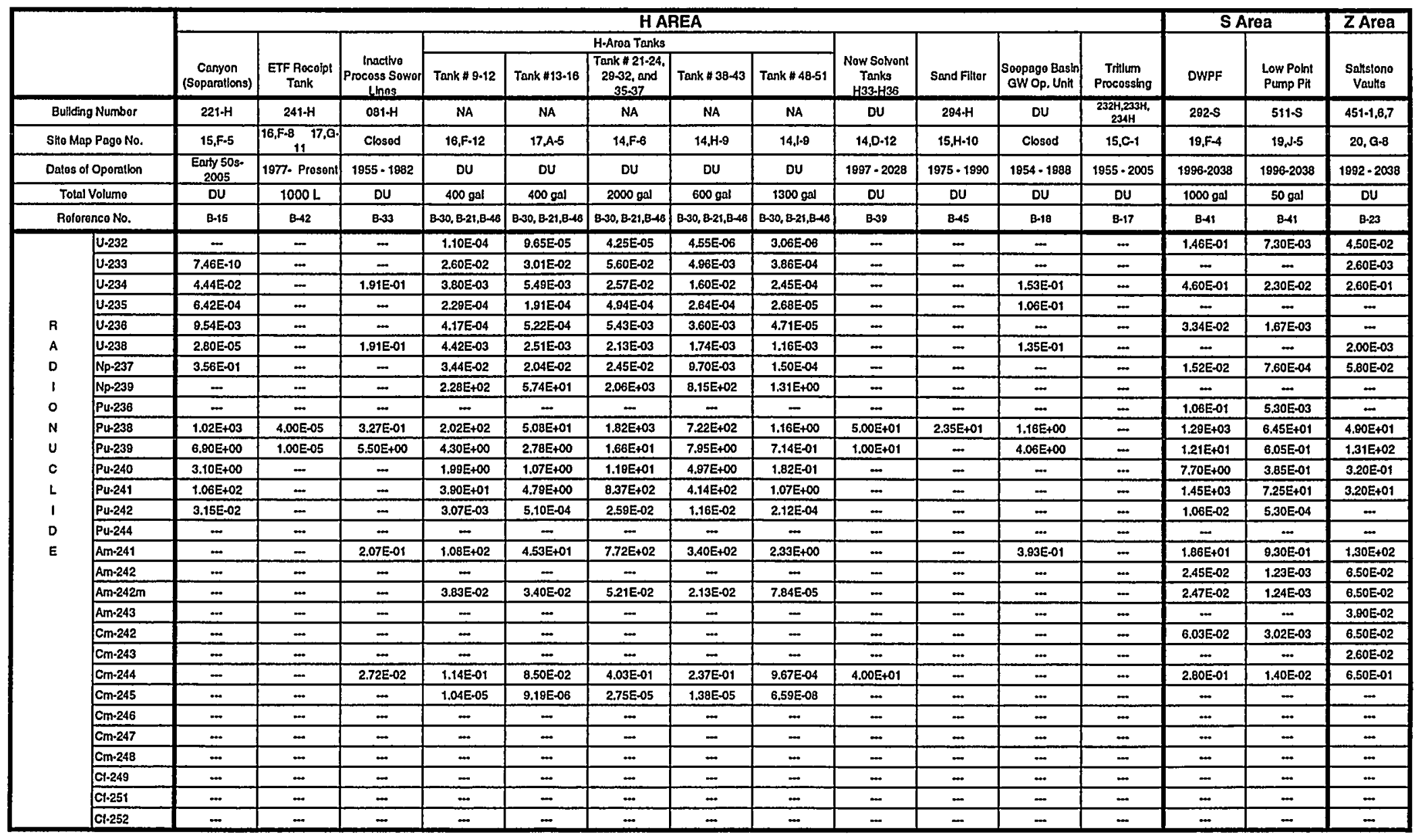




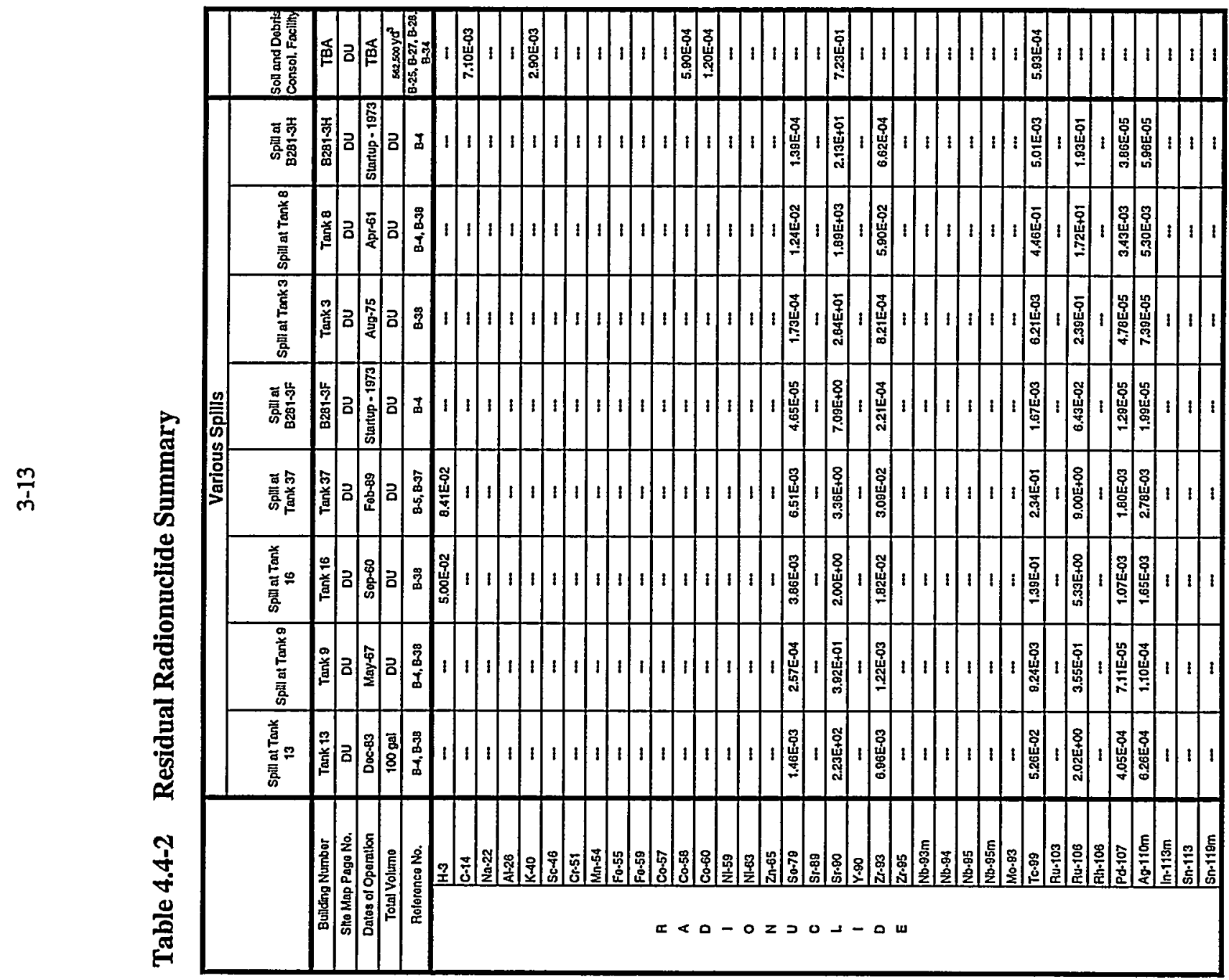




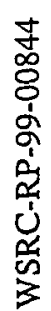

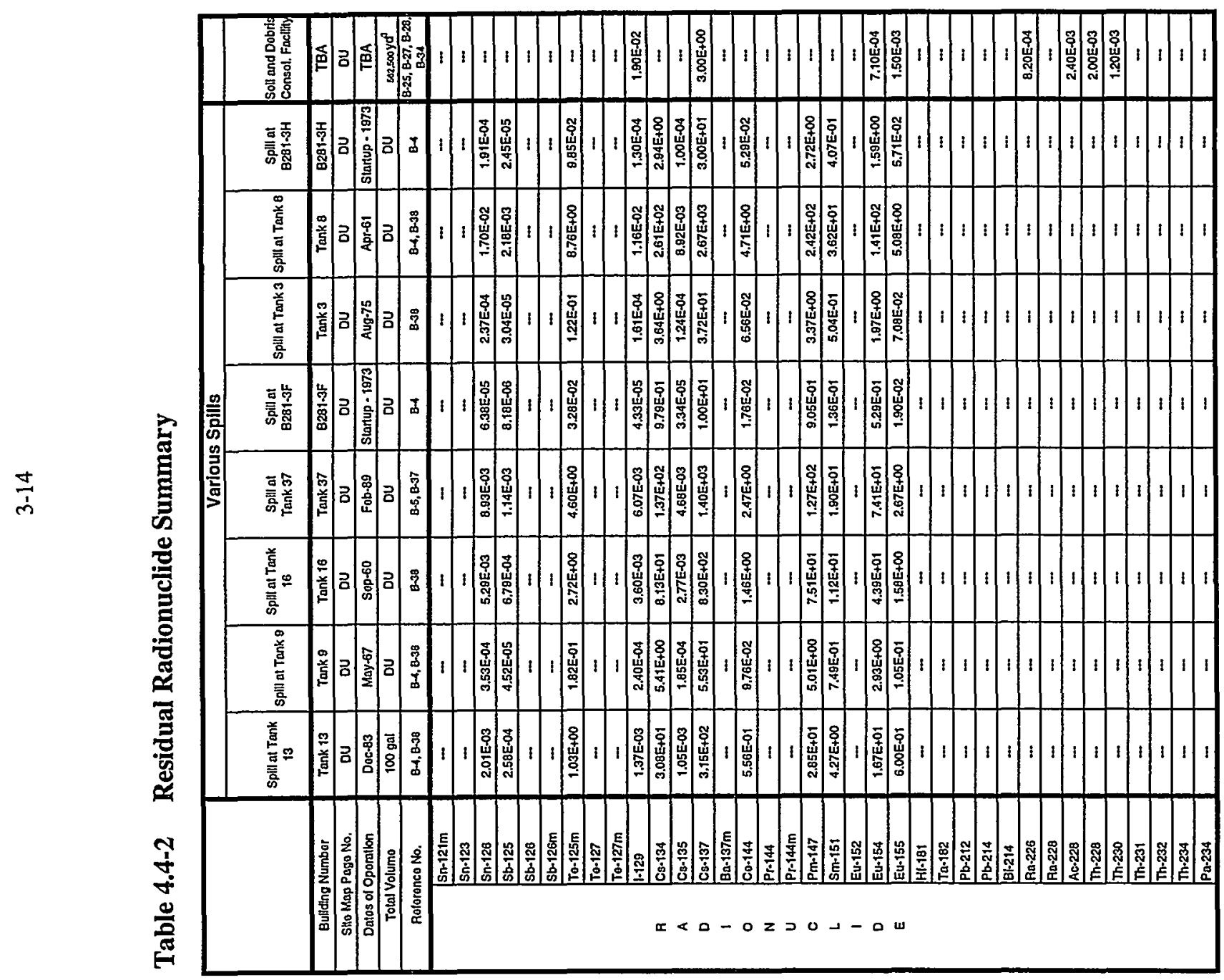


Table 4.4-2 Residual Radionuclide Summary

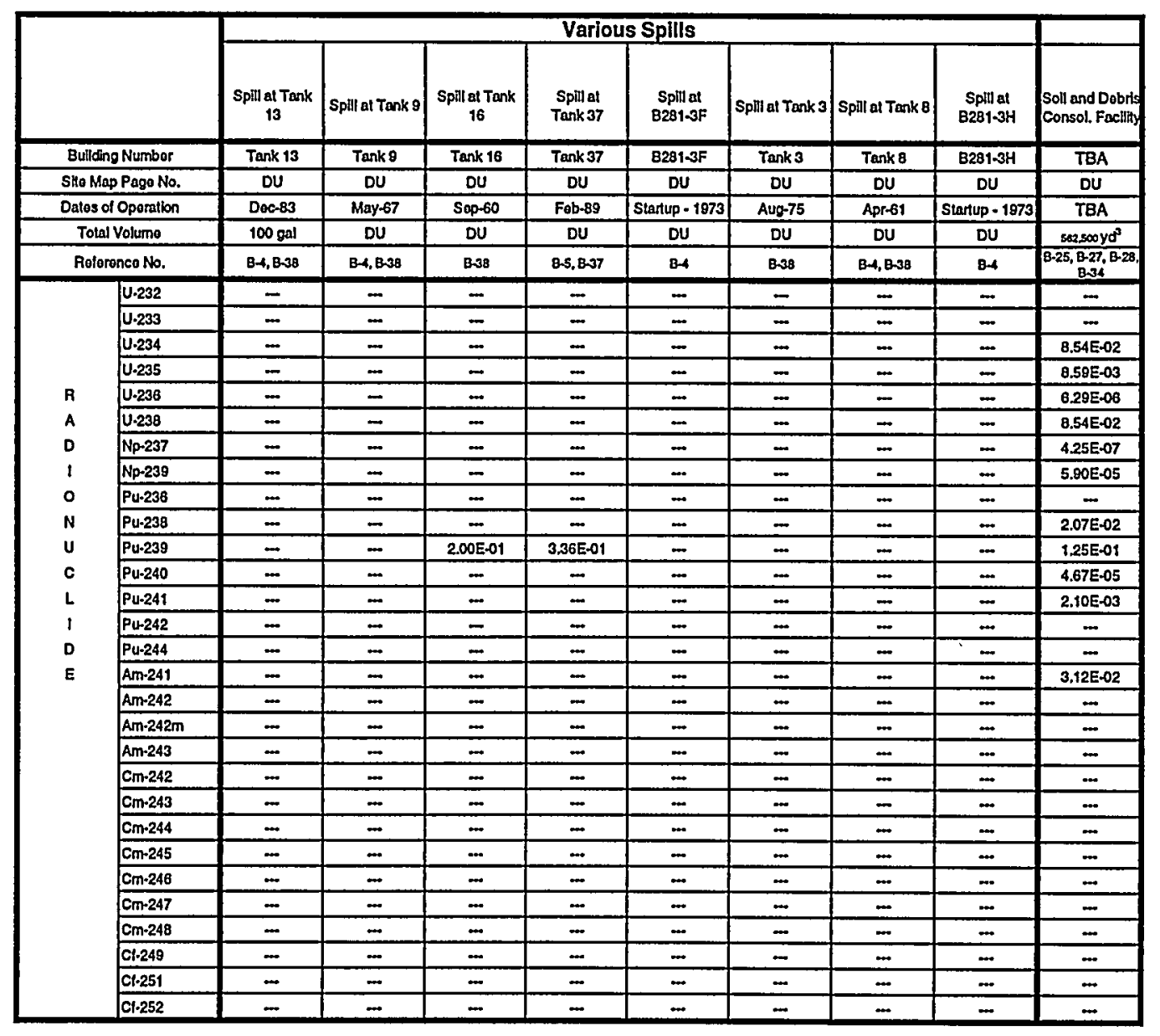




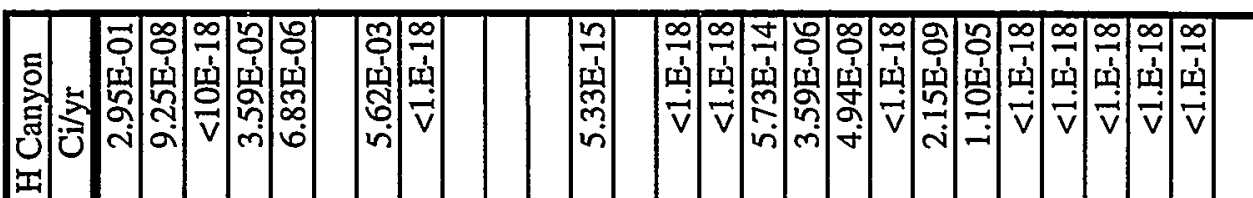

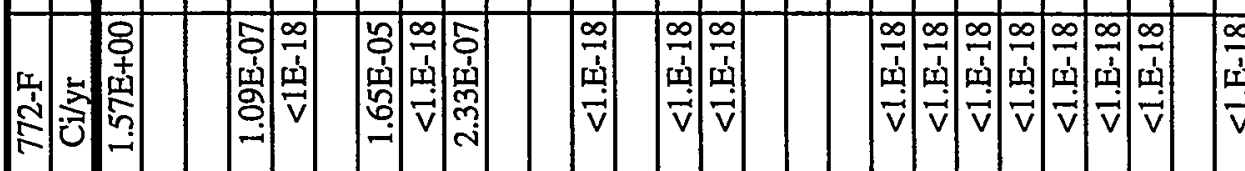

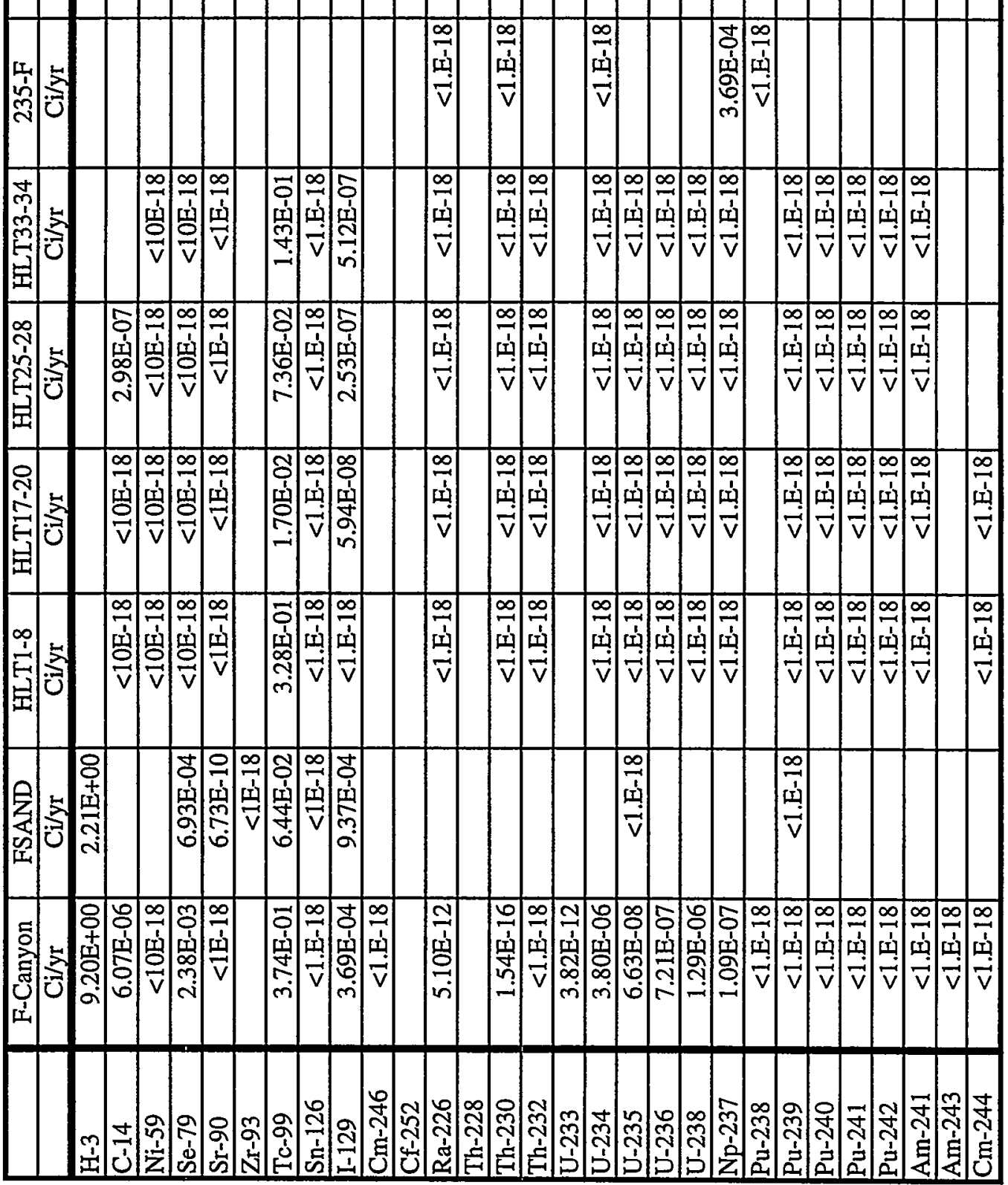


Table 4.4-5 Results of Flux to the Water Table Calculations up to 1,000 Years

\begin{tabular}{|c|c|c|c|c|c|c|c|c|c|}
\hline & HSAND & HLT9-12 & HLT13-16 & HLT21-24 & HLT38-43 & HLT48-51 & ETFTANKS & TRIT & FSEEP \\
\hline & $\mathrm{Ci} / \mathrm{yr}$ & $\mathrm{Ci} / \mathrm{yr}$ & $\mathrm{Ci} / \mathrm{yr}$ & $\mathrm{Ci} / \mathrm{yr}$ & $\mathrm{Ci} / \mathrm{yr}$ & $\mathrm{Ci} / \mathrm{yr}$ & $\mathrm{Ci} / \mathrm{yr}$ & $\mathrm{Ci} / \mathrm{yr}$ & $\mathrm{Ci} / \mathrm{yr}$ \\
\hline $\mathrm{H}-3$ & & & & & & & $2.52 \mathrm{E}-02$ & $6.30 \mathrm{E}+03$ & \\
\hline C-14 & & 1.95E-07 & $7.07 \mathrm{E}-08$ & $1.16 \mathrm{E}-07$ & $1.36 \mathrm{E}-07$ & $3.69 \mathrm{E}-09$ & & & \\
\hline $\mathrm{Ni}-59$ & & $8.36 \mathrm{E}-06$ & $7.02 \mathrm{E}-06$ & $<10 \mathrm{E}-18$ & $<10 \mathrm{E}-18$ & $<10 \mathrm{E}-18$ & & & \\
\hline Se-79 & $6.98 \mathrm{E}-04$ & $9.73 \mathrm{E}-04$ & $8.68 \mathrm{E}-04$ & $1.84 \mathrm{E}-03$ & $<1 E-18$ & $<1 \mathrm{E}-18$ & & & \\
\hline Sr-90 & $1.58 \mathrm{E}-04$ & $1.22 \mathrm{E}-02$ & $1.03 \mathrm{E}-02$ & $<1 . \mathrm{E}-18$ & $<1 . \mathrm{E}-18$ & $<1 . \mathrm{E}-18$ & $3.84 \mathrm{E}-10$ & & \\
\hline Zr-93 & $<1 \mathrm{E}-18$ & & & & & & & & \\
\hline Tc-99 & $6.57 \mathrm{E}-02$ & $1.65 \mathrm{E}-01$ & $1.46 \mathrm{E}-01$ & $2.58 \mathrm{E}-01$ & $1.06 \mathrm{E}-01$ & $9.49 \mathrm{E}-04$ & & & $6.05 \mathrm{E}-05$ \\
\hline Sn-126 & $<1 E-18$ & $4.70 \mathrm{E}-05$ & $4.18 \mathrm{E}-05$ & $<1 . E-18$ & $<1 . E-18$ & $<1 . \mathrm{E}-18$ & & & \\
\hline$I-129$ & $9.52 \mathrm{E}-04$ & $4.08 \mathrm{E}-07$ & $3.68 \mathrm{E}-07$ & $6.73 \mathrm{E}-07$ & $2.59 \mathrm{E}-07$ & $2.83 \mathrm{E}-09$ & $5.06 \mathrm{E}-06$ & & $6.80 \mathrm{E}-04$ \\
\hline \multicolumn{10}{|l|}{ Cm-246 } \\
\hline \multicolumn{10}{|l|}{ Cf-252 } \\
\hline $\mathrm{Ra}-226$ & & $1.51 \mathrm{E}-10$ & $2.34 \mathrm{E}-10$ & $2.74 \mathrm{E}-18$ & $<1 . \mathrm{E}-18$ & $<1 . \mathrm{E}-18$ & $2.73 \mathrm{E}-13$ & & $4.66 \mathrm{E}-09$ \\
\hline \multicolumn{10}{|l|}{ Th-228 } \\
\hline Th-230 & & $8.16 \mathrm{E}-10$ & $1.27 \mathrm{E}-09$ & $4.03 \mathrm{E}-17$ & $<1 . \mathrm{E}-18$ & $<1 . \mathrm{E}-18$ & $1.87 \mathrm{E}-12$ & & $1.88 \mathrm{E}-08$ \\
\hline Th-232 & & $1.04 \mathrm{E}-15$ & $1.62 \mathrm{E}-15$ & $<1 . E-18$ & $<1 . E-18$ & $<1 . E-18$ & & & \\
\hline $\mathrm{U}-233$ & & $2.36 \mathrm{E}-05$ & $2.73 \mathrm{E}-05$ & $2.79 \mathrm{E}-05$ & $<1 . \mathrm{E}-18$ & $<1 . \mathrm{E}-18$ & & & \\
\hline $\mathrm{U}-234$ & & $3.65 \mathrm{E}-06$ & $5.48 \mathrm{E}-06$ & $1.35 \mathrm{E}-05$ & $<1 . \mathrm{E}-18$ & $<1$. E-18 & $0.00 \mathrm{E}+00$ & & $0.00 \mathrm{E}+00$ \\
\hline U-235 & $<1 . E-18$ & $2.08 \mathrm{E}-07$ & $1.74 \mathrm{E}-07$ & $2.47 \mathrm{E}-07$ & $<1 . \mathrm{E}-18$ & $<1 . \mathrm{E}-18$ & $0.00 \mathrm{E}+00$ & & $0.00 \mathrm{E}+00$ \\
\hline U-236 & & $3.90 \mathrm{E}-04$ & $2.96 \mathrm{E}-04$ & $2.71 \mathrm{E}-06$ & $<1 . E-18$ & $<1 . \mathrm{E}-18$ & & & $0.00 \mathrm{E}+00$ \\
\hline U-238 & & $4.04 \mathrm{E}-06$ & $2.39 \mathrm{E}-06$ & $1.06 \mathrm{E}-06$ & $<1 . \mathrm{E}-18$ & $<1 . \mathrm{E}-18$ & & & $0.00 \mathrm{E}+00$ \\
\hline $\mathrm{Np}-237$ & & $7.89 \mathrm{E}-03$ & $2.62 \mathrm{E}-02$ & $2.28 \mathrm{E}-06$ & $<1 . \mathrm{E}-18$ & $<1 . \mathrm{E}-18$ & & & $0.00 \mathrm{E}+00$ \\
\hline Pu-238 & & $1.25 \mathrm{E}-08$ & $1.94 \mathrm{E}-08$ & $<1 . \mathrm{E}-18$ & $<1 . \mathrm{E}-18$ & $<1 . \mathrm{E}-18$ & & & \\
\hline $\mathrm{Pu}-239$ & $6.88 \mathrm{E}-07$ & $1.94 \mathrm{E}-08$ & $3.01 E-08$ & $<1 . \mathrm{E}-18$ & $<1 . E-18$ & $<1 . \mathrm{E}-18$ & $0.00 \mathrm{E}+00$ & & $0.00 \mathrm{E}+00$ \\
\hline $\mathrm{Pu}-240$ & & $4.18 \mathrm{E}-05$ & $3.18 \mathrm{E}-05$ & $<1 . \mathrm{E}-18$ & $<1 . E-18$ & $<1 . \mathrm{E}-18$ & & & \\
\hline $\mathrm{Pu}-241$ & & $8.60 \mathrm{E}-17$ & $1.34 \mathrm{E}-16$ & $<1 . \mathrm{E}-18$ & $<1 . \mathrm{E}-18$ & $<1 . \mathrm{E}-18$ & & & \\
\hline $\mathrm{Pu}-242$ & & $<1 . \mathrm{E}-18$ & $1.98 \mathrm{E}-09$ & $<1 . \mathrm{E}-18$ & $<1 . \mathrm{E}-18$ & $<1 . E-18$ & & & \\
\hline $\mathrm{Am}-241$ & & $5.97 \mathrm{E}-18$ & $7.70 \mathrm{E}-18$ & $<1 . \mathrm{E}-18$ & $<1 . \mathrm{E}-18$ & $<1 . \mathrm{E}-18$ & & & $0.00 \mathrm{E}+00$ \\
\hline \multicolumn{10}{|l|}{$\mathrm{Am}-243$} \\
\hline $\mathrm{Cm}-244$ & & $<1 . \mathrm{E}-18$ & $<1 . \mathrm{E}-18$ & $<1 . \mathrm{e}-18$ & $<1 . \mathrm{E}-18$ & $<1 . E-18$ & & & \\
\hline
\end{tabular}




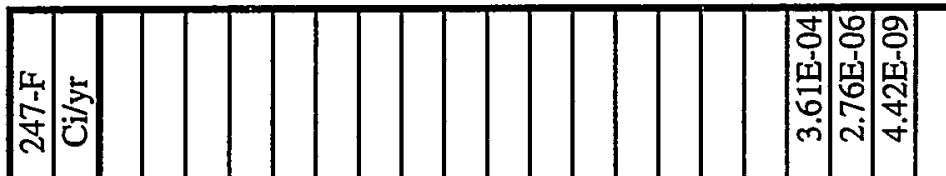

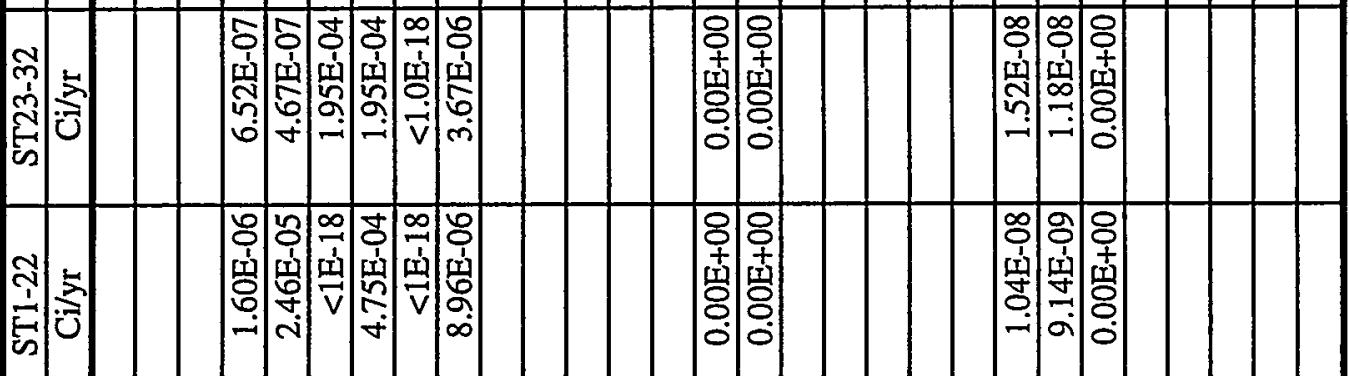

$\frac{\infty}{m}$

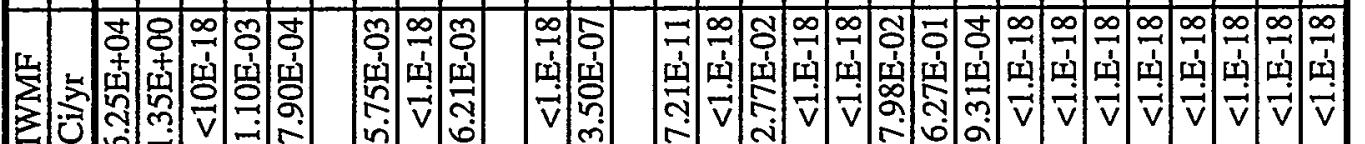




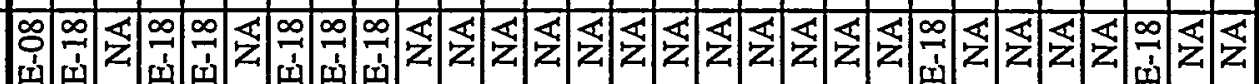

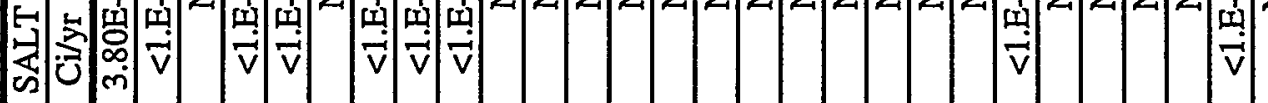

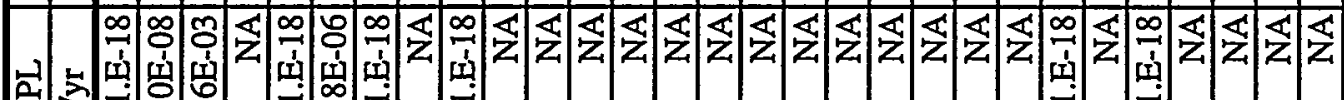

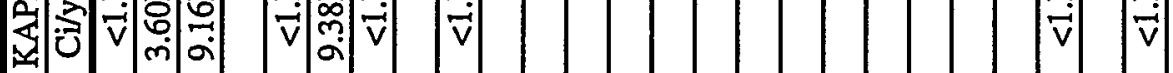

$\frac{a}{m}$

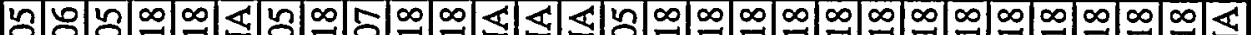

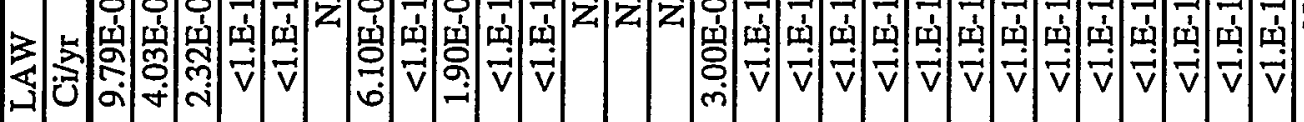

Q

窇<smiles>C1CC2(C1)CC2</smiles>

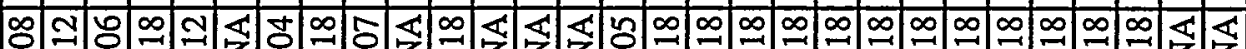
B

$m$ m $\infty$

$\frac{0}{0}$

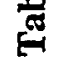

西

$\frac{1}{3}$

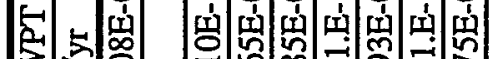

(n)

(O)

$\vec{V} \begin{gathered}0 \\ \text { ri }\end{gathered}$

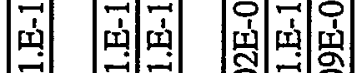

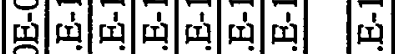

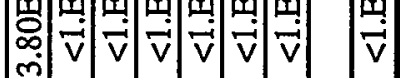

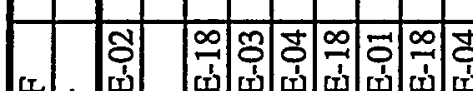

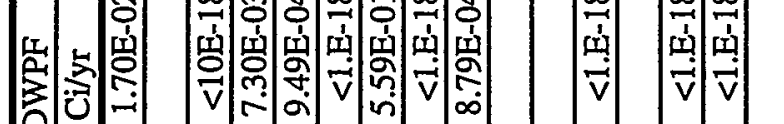

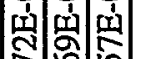

min

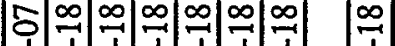

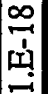

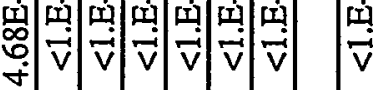

ूू

सेक्षे

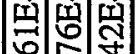

华

लें

草

(N)

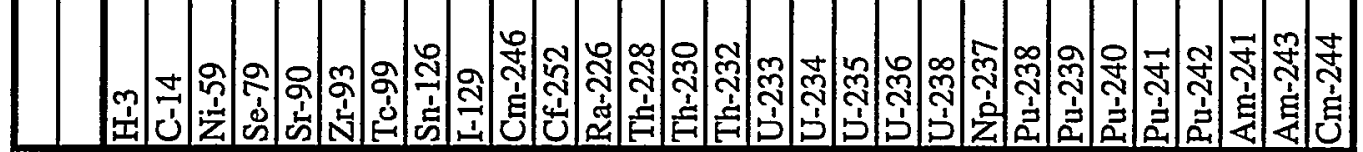


Table 4.4-5 Results of Flux to the Water Table Calculations up to 1,000 Years

\begin{tabular}{|c|c|c|c|c|c|c|c|c|}
\hline & Tank 13 & Tank 9 & Tank 16 & Tank 37 & B281-F & Tank 3 & Tank 8 & B281-H \\
\hline & Spill & Spill & Spill & Spill & Spill & Spill & Spill & Spill \\
\hline $\mathrm{H}-3$ & & & $2.36 \mathrm{E}-02$ & $3.82 \mathrm{E}-02$ & & & & \\
\hline \multicolumn{9}{|l|}{ C-14 } \\
\hline \multicolumn{9}{|l|}{$\mathrm{Ni}-59$} \\
\hline Se-79 & $4.35 \mathrm{E}-05$ & $7.65 \mathrm{E}-06$ & $1.15 \mathrm{E}-04$ & $1.94 \mathrm{E}-04$ & $1.38 \mathrm{E}-06$ & $4.87 \mathrm{E}-06$ & $3.49 \mathrm{E}-04$ & $4.13 \mathrm{E}-06$ \\
\hline Sr-90 & $8.84 \mathrm{E}-01$ & $1.55 \mathrm{E}-01$ & $7.93 \mathrm{E}-03$ & $9.19 \mathrm{E}-04$ & $1.41 \mathrm{E}-06$ & $6.71 \mathrm{E}-16$ & $4.80 \mathrm{E}-14$ & $4.23 \mathrm{E}-06$ \\
\hline $\mathrm{Zr}-93$ & $8.20 \mathrm{E}-07$ & $3.19 \mathrm{E}-07$ & $7.40 \mathrm{E}-06$ & $8.05 \mathrm{E}-06$ & $<1 \mathrm{E}-18$ & $<1 \mathrm{E}-18$ & $<1 E-18$ & $<1 \mathrm{E}-18$ \\
\hline Tc-99 & $3.62 \mathrm{E}-04$ & $6.37 \mathrm{E}-05$ & $9.58 \mathrm{E}-04$ & $1.61 \mathrm{E}-03$ & $1.15 \mathrm{E}-05$ & $3.42 \mathrm{E}-05$ & $2.46 \mathrm{E}-03$ & $3.45 \mathrm{E}-05$ \\
\hline Sn-126 & $2.41 \mathrm{E}-06$ & 4.23E-07 & $6.35 \mathrm{E}-06$ & $<1 \mathrm{E}-18$ & $<1 \mathrm{E}-18$ & $<1 \mathrm{E}-18$ & $<1 E-18$ & $<1 \mathrm{E}-18$ \\
\hline I-129 & $2.43 \mathrm{E}-04$ & $4.26 \mathrm{E}-05$ & $6.40 \mathrm{E}-04$ & $1.09 \mathrm{E}-03$ & 7.77E-06 & $2.61 \mathrm{E}-05$ & $1.88 \mathrm{E}-03$ & $2.33 \mathrm{E}-05$ \\
\hline \multicolumn{9}{|l|}{$\mathrm{Cm}-246$} \\
\hline \multicolumn{9}{|l|}{$\mathrm{Cf}-252$} \\
\hline \multicolumn{9}{|l|}{ Ra-226 } \\
\hline \multicolumn{9}{|l|}{ Th-228 } \\
\hline \multicolumn{9}{|l|}{ Th-230 } \\
\hline \multirow{2}{*}{\multicolumn{9}{|c|}{ Th-232 }} \\
\hline \multirow{2}{*}{\multicolumn{8}{|c|}{$\frac{U-233}{U-234}$}} & \\
\hline & & & & & & & & \\
\hline U-235 & & & $<1 \mathrm{E}-18$ & $<1 \mathrm{E}-18$ & & & & \\
\hline \multicolumn{9}{|l|}{$\mathrm{U}-236$} \\
\hline \multicolumn{9}{|l|}{$\mathrm{U}-238$} \\
\hline \multicolumn{9}{|l|}{$\mathrm{Np}-237$} \\
\hline \multicolumn{9}{|l|}{$\mathrm{Pu}-238$} \\
\hline Pu-239 & & & $5.72 \mathrm{E}-08$ & $5.72 \mathrm{E}-08$ & & & & \\
\hline \multicolumn{9}{|l|}{$\mathrm{Pu}-240$} \\
\hline \multicolumn{9}{|l|}{ Pu-241 } \\
\hline \multicolumn{9}{|l|}{$\mathrm{Pu}-242$} \\
\hline \multicolumn{9}{|l|}{ Am-241 } \\
\hline \multicolumn{9}{|l|}{ Am-243 } \\
\hline Cm-244 & & & & & & & & \\
\hline
\end{tabular}




\subsection{References}

J. B. Pickett, W. P. Colven and H. W. Bledsoe, Environmental Information Document, M-Area Settling Basin and Vicinity, DPST-85-703, March 1987.

Stewart, Donald C., 1985. Data for Radioactive Waste Management and Nuclear Applications. John Wiley \& Sons, New York, New York. 1985. 
THIS PAGE INTENTIONALLY LEFT BLANK 


\subsection{Condition 4}

Include in the addendum to the composite analysis the assumptions and justification for the assumptions used in the analysis.

Table 4-1 lists the assumptions in the Savannah River Site Composite Analysis (CA) with their associated justification. Where the justification for the assumption is stated in the CA, or where the justification is self-evident, the assumption was omitted from the list. 
Table 4-1 Assumptions and Justifications for the Savannah River Composite Analysis E-Area Vaults and Saltstone Facility

\begin{tabular}{|c|c|c|}
\hline $\begin{array}{l}\text { Location in } \\
\text { CA } \\
\text { Document }\end{array}$ & Assumption & Justification \\
\hline \multicolumn{3}{|c|}{ Section 1.0 Summary and Conclusions } \\
\hline \multirow[t]{3}{*}{ Page 1-1 } & $\begin{array}{l}\text {...prepare a CA that evaluates the impact to a } \\
\text { hypothetical future member of the public from } \\
\text { all radioactive sources that potentially interact } \\
\text { with LLW disposal facilities. Therefore, the } \\
\text { CA considered interaction of radionuclide } \\
\text { sources in the GSA with the active } E \text { and } Z \\
\text { Area disposal facilities. }\end{array}$ & $\begin{array}{l}\text { The intent of the USDOE requirement for a CA is to } \\
\text { consider the potential impact of other sources on the } \\
\text { operations of a LLW disposal facility. SRS chose to } \\
\text { restrict the CA to those sources within the GSA } \\
\text { because it is those sources that would influence } \\
\text { operations at the LLW disposal facilities. } \\
\text { Radionuclides from other sources at the SRS, such as } \\
\text { the reactor areas, will eventually migrate through } \\
\text { groundwater to surface streams and will ultimately } \\
\text { mix with contaminants from the GSA in the Savannah } \\
\text { River. However, by the time the contaminants have } \\
\text { mixed in the River, dilution will be so great that the } \\
\text { calculated impact will be small. }\end{array}$ \\
\hline & $\begin{array}{l}\text { Therefore, the mouth of Upper Three Runs is } \\
\text { the appropriate point to assess the effect of } \\
\text { sources that potentially interact with } E \text { and } Z \\
\text { Areas. }\end{array}$ & $\begin{array}{l}\text { The mouth of UTR is the closest point to the GSA that } \\
\text { a hypothetical future member of the public could } \\
\text { reasonably be expected to be exposed to radionuclides } \\
\text { from the GSA, given the current SRS land use plan. }\end{array}$ \\
\hline & $\begin{array}{l}\text { The CA included for completeness the } \\
\text { assessment of the mouth of Four Mile Branch } \\
\text { and the Savannah River at the Highway } 301 \\
\text { bridge. }\end{array}$ & $\begin{array}{l}\text { The GSA includes facilities that drain to FMB as well } \\
\text { as UTR. Even though a local groundwater divide } \\
\text { effectively prohibits those sources which drain to } \\
\text { FMB from influencing UTR, it was felt to be } \\
\text { worthwhile to include the analysis of the FMB } \\
\text { watershed for completeness since the FMB watershed } \\
\text { includes past waste disposal facilities. }\end{array}$ \\
\hline \multicolumn{3}{|c|}{ Section 2.1 Introduction, Purpose and Scope } \\
\hline Page 2-2/3 & $\begin{array}{l}\text { Z-Area and E-Area LLW disposal facilities and } \\
\text { other sources of radioactive material in the } \\
\text { vicinity of these facilities. Total projected dose } \\
\text { from all sources will be compared with the } \\
\text { USDOE primary dose limit of } 100 \text { mrem per } \\
\text { year. The ALARA concept will also be } \\
\text { explored in terms of estimated maximum } \\
\text { individual doses, collective doses, and } \\
\text { alternative controls. For example, if projected } \\
\text { maximum individual dose is in excess of } 30 \\
\text { mrem per year, an options analysis to identify } \\
\text { alternatives that would reduce future doses } \\
\text { would be explored. }\end{array}$ & $\begin{array}{l}\text { The USDOE guidance for conducting the CA requires } \\
\text { inclusion of the active LLW disposal facilities (i.e., Z- } \\
\text { Area and E-Area) and other sources of radioactive } \\
\text { material. The guidance further requires that the total } \\
\text { projected dose from all of the sources determined to } \\
\text { interact be compared with the USDOE primary dose } \\
\text { limit of } 100 \text { mrem in a year. The guidance also } \\
\text { requires consideration of the ALARA concept. It also } \\
\text { requires development of an options analysis if the } \\
\text { projected maximum individual dose exceeds } 30 \text { mrem } \\
\text { in a year. }\end{array}$ \\
\hline
\end{tabular}


Section 2.2 Description of the GSA

\begin{tabular}{|l|l|}
\hline Page 2-3 & The GSA contains major processing and waste
\end{tabular} management areas that will contain residual radioactivity after USDOE operations at SRS cease. The areas are E Area, F Area, $H$ Area, S Area, and $\mathrm{Z}$ Area.

It was assumed that several of the facilities within the GSA (e.g., former LLW burial grounds, seepage basins, HLW storage tanks) would not be "cleanclosed" (i.e., all radioactivity removed prior to closure). Thus, it was assumed that some residual radioactive material would remain in the GSA when all operations and clean up activities had been completed.

Section 2.3.5.2 Floridan Aquifer System

\begin{tabular}{l|l}
\hline Page 2-23 & Because of relative hydrologic isolation due to
\end{tabular} the Meyers Branch confining system, only the Floridan aquifer system is of interest in the Composite Analysis of potential groundwater contamination from operations at the GSA. The Floridan aquifer system is comprised of the lowermost Gordon aquifer unit, the Gordon confining unit, and the uppermost Upper Three Runs aquifer, which contains the water table.
Within the GSA, the Meyers Branch confining system separates the Floridan aquifer system from the underlying aquifer systems. Because of higher hydraulic head in the lower aquifer systems than in the Floridan system, water tends to migrate upward from the lower aquifer systems into the Floridan system. Thus, sources of radioactive material within the GSA cannot contaminate the lower aquifer systems.

The PAs for the E-Area and Z-Area LLW disposal facilities showed very little potential for migration of non-volatile radionuclides from the disposed waste to the ground surface. Thus, the only potential for migration is via groundwater. Due to the local hydrogeology, the two streams, FMB and UTR capture groundwater within the GSA, thus, groundwater and surface water are two media that could be contaminated by radionuclides contained in facilities located in the GSA. Although the PA for EArea evaluated the migration of volatile tritium from disposed waste, it was judged that such migration would not contribute significantly in the $\mathrm{CA}$ because of dilution resulting from the transport to the much more distant point of assessment.

The SRS Land Use Plan foresees no return of any portion of the SRS to unrestricted use by the public. The Plan foresees only heavy industrial use for the GSA. Therefore, the future public will have no access to groundwater within the GSA. the public of potentially-contaminated groundwater is not a reasonable expectation.

\begin{tabular}{l|l} 
Page 2-35 & Contaminated surface water is considered a
\end{tabular} potential source of exposure to a hypothetical future member of the public in this analysis.
Due to the local hydrogeology, the two streams, FMB and UTR capture groundwater within the GSA. Both FMB and UTR drain to the Savannah River which borders the SRS. Thus, the future public could be exposed to contaminated surface water. 


\begin{tabular}{|c|c|c|}
\hline & $\begin{array}{l}\text { While land-use plans are expected to restrict } \\
\text { use of the SRS during the time period of the } \\
\text { analysis, the confluence of on-site streams with } \\
\text { the Savannah River poses a potential means of } \\
\text { public access to contaminated environmental } \\
\text { media. Thus, the points of assessment for this } \\
\text { analysis are the mouths of UTR and FMB and } \\
\text { the Savannah River. }\end{array}$ & $\begin{array}{l}\text { The SRS Land Use Plan foresees no return of any } \\
\text { portion of the SRS to unrestricted use by the public. } \\
\text { However, the Land Use Plan does not include } \\
\text { restricted access to the Savannah River adjacent to } \\
\text { SRS. Thus, the future public will have access to the } \\
\text { mouths of UTR and FMB (the confluence of the } \\
\text { streams and the river) and these points are logical } \\
\text { points of assessment. }\end{array}$ \\
\hline & $\begin{array}{l}\text { Thus, the mouths of UTR and FMB, at the } \\
\text { furthest downstream point where stream water } \\
\text { remains undiluted with Savannah River water, } \\
\text { are points for the assessment of potential dose } \\
\text { to a hypothetical future member of the public. }\end{array}$ & $\begin{array}{l}\text { To provide an appropriate degree of conservatism in } \\
\text { the analysis, it was assumed that the public would } \\
\text { have access to water in UTR and FMB at the mouths } \\
\text { of the streams but before dilution of the stream water } \\
\text { with water from the Savannah River. }\end{array}$ \\
\hline \multirow[t]{3}{*}{ Page $2-35$} & $\begin{array}{l}\text { Additionally, the Savannah River will continue } \\
\text { to be a point of public access. }\end{array}$ & $\begin{array}{l}\text { Since the Savannah River is now accessible to the } \\
\text { public and the SRS Land Use Plan does not include } \\
\text { restrictions on access to the River, the Savannah River } \\
\text { is logically a point of public access. }\end{array}$ \\
\hline & $\begin{array}{l}\text {..this composite analysis evaluates the dose to } \\
\text { a hypothetical future member of the public at } \\
\text { the highway } 301 \text { bridge, } 20 \mathrm{~km} \text { downstream of } \\
\text { the SRS. }\end{array}$ & $\begin{array}{l}\text { Dose was evaluated due to exposure to Savannah } \\
\text { River water at the highway } 301 \text { bridge for } \\
\text { convenience of comparison with data from the SRS } \\
\text { Environmental Monitoring Program. }\end{array}$ \\
\hline & $\begin{array}{l}\text { Concentrations of radioactive material at the } \\
\text { mouths of UTR and FMB will potentially } \\
\text { include contributions from sources outside the } \\
\text { GSA. At the highway- } 301 \text { bridge, all sources } \\
\text { of residual radioactive material on the SRS } \\
\text { could potentially contribute to calculated dose. } \\
\text { The composite analysis, however, has only } \\
\text { considered the sources within the GSA because } \\
\text { it is those sources that could influence } \\
\text { decisions regarding operations of the LLW } \\
\text { disposal facilities. }\end{array}$ & $\begin{array}{l}\text { Several sources of radioactive material outside the } \\
\text { GSA could contribute to contamination of UTR (e.g., } \\
\text { M-Area seepage basin, SRI seepage basins) and to } \\
\text { FMB (e.g., C-Reactor). Eventually, at the highway- } \\
301 \text { bridge, several miles downstream of the SRS, all } \\
\text { sources of residual radioactive material on the entire } \\
\text { SRS would contribute to the potential dose to a } \\
\text { hypothetical future member of the public. } \\
\text { Nonetheless, SRS decided, for this first iteration of the } \\
\text { CA, to only consider sources within the GSA. This } \\
\text { decision was made for several reasons. First, it was } \\
\text { judged that the sources outside the GSA would make a } \\
\text { relatively small contribution to the total dose. Second, } \\
\text { if a source outside the GSA contributed a significant } \\
\text { amount to the total dose and the total dose warranted } \\
\text { some action, the action would not involve operations } \\
\text { of the LLW disposal facilities. Rather, the action } \\
\text { would involve remediation of the contributing source. } \\
\text { Third, USDOE guidance is that the CA is an interim } \\
\text { requirement focussed on the active LLW disposal } \\
\text { facilities. USDOE is developing a comprehensive } \\
\text { environmental management systems approach which } \\
\text { will consider all potential sources of residual } \\
\text { radioactive material on a site. Thus, this first iteration } \\
\text { of the CA need not include all sources of residual } \\
\text { radioactive material on the SRS. }\end{array}$ \\
\hline
\end{tabular}




\begin{tabular}{|c|c|c|}
\hline Page 2-36 & $\begin{array}{l}\text { Two other locations were selected to assess the } \\
\text { sensitivity of the composite analysis to future } \\
\text { land use decisions. These locations are on } \\
\text { Upper Three Runs and Four Mile Branch, just } \\
\text { downstream of the recharge points from } \\
\text { groundwater passing under the GSA. These } \\
\text { locations were selected because they represent } \\
\text { points at which maximum surface water } \\
\text { concentrations are expected to occur. }\end{array}$ & $\begin{array}{l}\text { USDOE guidance for the CA indicates that sensitivity } \\
\text { analysis should be focussed on land use, Alteration of } \\
\text { the SRS Land Use Plan to permit public access to } \\
\text { UTR and FMB on the current SRS reservation was } \\
\text { considered credible but unlikely. However, it was not } \\
\text { considered credible that the Plan would be altered to } \\
\text { allow public access within the GSA. Thus, in the } \\
\text { sensitivity analysis, the public was assumed to have } \\
\text { access to the streams up to the edge of the GSA, but } \\
\text { not within the GSA. }\end{array}$ \\
\hline Page 2-37 & $\begin{array}{l}\text { For the assessment of potential collective dose } \\
\text { to future populations, the population within an } \\
80-\mathrm{km} \text { radius of the center of the SRS is } \\
\text { assumed to participate in recreational activities } \\
\text { at the highway } 301 \text {-bridge location on the } \\
\text { Savannah River. Two additional locations on } \\
\text { the Savannah River are also used: } 1 \text { ) } 160 \mathrm{~km} \\
\text { downstream of the SRS at the Beaufort-Jasper, } \\
\text { SC water treatment plant; and 2) } 160 \mathrm{~km} \\
\text { downstream of the SRS at the Port Wentworth, } \\
\text { GA water treatment plant. These locations } \\
\text { were selected because they represent present } \\
\text { populations considered in the SRS annual } \\
\text { environmental monitoring public report } \\
\text { (WSRC, 1996c). }\end{array}$ & $\begin{array}{l}\text { The SRS annual environmental report assesses the } \\
\text { potential dose to the current population within } 80-\mathrm{km} \\
\text { of the SRS, which is consistent with NRC Regulatory } \\
\text { Guide } 1.109 \text {. The report also assesses potential dose } \\
\text { to downstream river water users. It was decided that } \\
\text { the CA should consider the same populations. }\end{array}$ \\
\hline \multicolumn{3}{|c|}{ Section 2.4.2 Time of Assessment } \\
\hline Page 2-37 & $\begin{array}{l}\text {...the Composite Analysis for the SRS GSA } \\
\text { considers maximum doses that may potentially } \\
\text { be received by a hypothetical future member of } \\
\text { the public within a time period of at least } 1,000 \\
\text { years. For long-lived and strongly-sorbing } \\
\text { radionuclides, the actual peak dose may occur } \\
\text { at times beyond } 1,000 \text { years due to slow transit } \\
\text { times in soil and groundwater. For these } \\
\text { radionuclides, a dose at } 1,000 \text { years is } \\
\text { estimated, along with a peak dose and the time } \\
\text { of occurrence of the peak dose. }\end{array}$ & $\begin{array}{l}\text { USDOE guidance for the CA requires that doses } \\
\text { within } 1,000 \text { years following closure of the LLW } \\
\text { disposal facilities be considered. The SRS CA } \\
\text { calculated doses over this } 1,000 \text {-year period. } \\
\text { Additionally, for completeness, the CA presented the } \\
\text { calculated maximum dose, and the time of the } \\
\text { maximum, for doses occurring beyond the } 1,000 \text {-year } \\
\text { period. }\end{array}$ \\
\hline \multicolumn{3}{|c|}{ Section 3.2.4 Data Quality Objectives, DQO Development, Step 4: Define the Study Boundaries } \\
\hline \multirow[t]{2}{*}{ Page 3-6 } & $\begin{array}{l}\text { Due to the projected Composite Analysis } \\
\text { completion date of September } 1997, \text { no data } \\
\text { provided after first quarter of } 1997 \text { were used } \\
\text { in this Composite Analysis. }\end{array}$ & $\begin{array}{l}\text { To allow completion of the CA on the schedule that } \\
\text { had been committed to, it was necessary to establish a } \\
\text { time-frame after which no further data would be } \\
\text { included. The first quarter of } 1997 \text { was selected. }\end{array}$ \\
\hline & $\begin{array}{l}\text { There is no way to statistically validate the } \\
\text { historical records; rather, many different } \\
\text { sources of data were exploited to limit } \\
\text { uncertainty. }\end{array}$ & $\begin{array}{l}\text { Since it was judged to be impossible to develop } \\
\text { statistical validation of the historical data records, it } \\
\text { was decided to use as many different sources of data } \\
\text { to limit the uncertainty. }\end{array}$ \\
\hline
\end{tabular}




\begin{tabular}{|c|c|c|}
\hline & $\begin{array}{l}\text { The scope of the Composite Analysis is } \\
\text { confined to residual radionuclide inventories } \\
\text { and releases. Releases that contain no } \\
\text { radioactive contaminants were not considered. }\end{array}$ & $\begin{array}{l}\text { USDOE guidance on the CA restricts the analysis to } \\
\text { radiological constituents only. }\end{array}$ \\
\hline \multicolumn{3}{|c|}{ Section 3.2.7 Step 7: Optimize the Design } \\
\hline Page 3-7 & $\begin{array}{l}\text { After consideration of these two alternatives, a } \\
\text { program of collecting historical residual } \\
\text { radionuclide data for the GSA was identified } \\
\text { as the most effective and timely method for } \\
\text { compiling the initial inventory for the } \\
\text { Composite Analysis. }\end{array}$ & $\begin{array}{l}\text { The cost and lengthy time that would be required to } \\
\text { characterize existing contamination by collecting } \\
\text { samples and analyzing them resulted in the selection } \\
\text { of historical data to develop the necessary source } \\
\text { characterization. }\end{array}$ \\
\hline \multicolumn{3}{|c|}{ Section 4.1.1 Source Term Development, Potential Sources of Radioactive Material, E-Area } \\
\hline Page 4-4 & $\begin{array}{l}\text { For these tanks a total of } 550 \mathrm{Ci} \text { of alpha } \\
\text { emitters and } 11 \mathrm{Ci} \text { of beta-gamma emitters are } \\
\text { estimated to be present, based on an assumed } \\
\text { inventory of } 25 \mathrm{Ci} \text { of alpha emitters and } 0.5 \mathrm{Ci} \\
\text { of beta-gamma emitters in each tank. The alpha } \\
\text { activity is assumed to be } 40 \text { percent }{ }^{244} \mathrm{Cm}, 50 \\
\text { percent }{ }^{238} \mathrm{Pu} \text {, and } 10 \text { percent }{ }^{239} \mathrm{Pu} \text {. It is also } \\
\text { assumed that there are } 0.5 \mathrm{Ci} \text { of beta-gamma } \\
\text { emitters in each tank for a total of } 11 \mathrm{Ci} \text {. The } \\
\text { beta-gamma activity is assumed to be }{ }^{137} \mathrm{Cs} \\
\text { (Cole } 1996 \mathrm{a} \text { ). }\end{array}$ & $\begin{array}{l}\text { Since there are } 22 \text { tanks, the total inventory is } 22 \\
\text { times the estimated average inventory. The assumed } \\
\text { distribution of alpha emitters is based on } \\
\text { spectroscopic analysis of tank residues. The review } \\
\text { team challenged the assumption that all of the beta- } \\
\text { gamma activity is }{ }^{137} \mathrm{Cs} \text {, which is based on the solvent } \\
\text { tank remediation team's analyses. The inventory has } \\
\text { been reassessed, based on fission-product } \\
\text { distributions, to estimate the inventory of a number of } \\
\text { other radionuclides. }\end{array}$ \\
\hline Page 4-5/6 & $\begin{array}{l}\text { For the purposes of this radionuclide inventory } \\
\text { estimate a total of } 225 \mathrm{Ci} \text { of alpha emitters and } \\
4.5 \mathrm{Ci} \text { of beta-gamma emitters are estimated to } \\
\text { be in these nine tanks, based on an assumed } \\
\text { residual activity of } 25 \mathrm{Ci} \text { of alpha emitters and } \\
0.5 \mathrm{Ci} \text { of beta-gamma emitters in each tank. } \\
\text { The alpha activity is assumed to be } 40 \text { percent } \\
{ }^{244} \mathrm{Cm}, 50 \text { percent }{ }^{238} \mathrm{Pu} \text {, and } 10 \text { percent }{ }^{239} \mathrm{Pu} \text {. } \\
\text { The beta-gamma activity is assumed to be } \\
{ }^{137} \mathrm{Cs} \text { (Shappell 1996). }\end{array}$ & See above. \\
\hline
\end{tabular}




\begin{tabular}{|c|c|c|}
\hline \multicolumn{3}{|c|}{ Section 4.1.2 F and $\mathrm{H}$ Areas } \\
\hline Page 4-8/9 & $\begin{array}{l}\text { The F- and H-Area Sand Filters are part of the } \\
\text { off-gas system for the F-and H-Area } \\
\text { separations facilities. The sand filters are } \\
\text { contaminated with radionuclides; therefore, } \\
\text { they may contribute to the Composite } \\
\text { Analysis. For the purposes of this study, the } \\
\text { two old sand filters were assumed to have } \\
\text { operated from } 1960 \text { through } 1990 \text { and the two } \\
\text { new sand filters operated from } 1975 \text { through } \\
1990 \text {. Measurements show that during canyon } \\
\text { operations each of the filters accumulate a total } \\
\text { of } 2000 \mathrm{Ci} / \text { year of beta-gamma activity and } 0.5 \\
\text { Ci/year of alpha activity. The beta-gamma } \\
\text { activity is assumed to be composed of } 32.8 \\
\text { percent }{ }^{106} \mathrm{Ru}, 12.6 \text { percent }{ }^{137} \mathrm{Cs,} \mathrm{and} 54.6 \\
\text { percent }{ }^{144} \mathrm{Ce} \text { (Sykes and Harper } 1968 \text { ). The } \\
\text { alpha activity is assumed to be composed of } \\
{ }^{239} \mathrm{Pu} \text { in the F-Area Sand Filter and }{ }^{238} \mathrm{Pu} \text { in the } \\
\mathrm{H} \text {-Area Sand Filter. }\end{array}$ & $\begin{array}{l}\text { The assumed period of operation was conservatively } \\
\text { assigned, based on operating history, to fully } \\
\text { encompass, and slightly exceed, the actual period of } \\
\text { operation. The distribution of fission products in the } \\
\text { sand filters is based on analysis of the air stream being } \\
\text { filtered. The alpha activity distribution is based on the } \\
\text { operational history of the two facilities. } \\
\text { In response to Condition } 3 \text {, the fission product } \\
\text { distribution was reassessed to include longer-lived } \\
\text { species such as }{ }^{99} \mathrm{Tc} \text {. }\end{array}$ \\
\hline \multirow[t]{2}{*}{ Page 4-9 } & $\begin{array}{l}\text { Since }{ }^{65} \mathrm{Zn} \text { has a half-life of less than one year, } \\
\text { it will not be a significant contributor to the } \\
\text { residual radionuclide inventory estimate for the } \\
\text { tritium production facilities. }\end{array}$ & $\begin{array}{l}\text { Zinc- } 65 \text { has a half-life of } 244 \text { days. Even if zinc } \\
\text { migrated through the subsurface environment at the } \\
\text { same rate as tritium, it would go through several tens } \\
\text { of half lives before migrating to UTR. Thus, it would } \\
\text { have essentially decayed away. }\end{array}$ \\
\hline & $\begin{array}{l}\text { For the purposes of this residual radionuclide } \\
\text { inventory estimate, the amount of residual } \\
\text { radionuclides remaining after } D \& D \text { is assumed } \\
\text { to be } 10,000 \mathrm{Ci} \text { of tritium for each of the three } \\
\text { tritium production buildings (Hsu 1996). }\end{array}$ & $\begin{array}{l}\text { The estimated residual tritium is based on the Process } \\
\text { Waste Assessment prepared for the facility and the } \\
\text { assumption that quantities exceeding a gram of tritium } \\
\text { would be recovered due to the value of the tritium. }\end{array}$ \\
\hline Page 4-10 & $\begin{array}{l}\text { For the purposes of this residual radionuclide } \\
\text { inventory, the majority of the tanks are } \\
\text { assumed to have } 378 \mathrm{~L} \text { ( } 100 \text { gal) of sludge } \\
\text { remaining after cleaning; a few of the tanks are } \\
\text { assumed to have as much as } 7570 \mathrm{~L} \text { ( } 2000 \mathrm{gal} \text { ) } \\
\text { of sludge remaining prior to filling with grout } \\
\text { (d'Entremont } 1997 \text {; Hester } 1996 \mathrm{a} \text {; Hester } \\
\text { 1996b). Ancillary equipment such as piping } \\
\text { and pumps will add } 20 \text { percent to the residual } \\
\text { radionuclide total for the tanks. The density of } \\
\text { the sludge is expected to be about } 0.234 \mathrm{~kg} / \mathrm{L} \\
\text { (1.95 lb/gal). }\end{array}$ & $\begin{array}{l}\text { The estimated residual waste is based on operational } \\
\text { history and construction details of each tank, and the } \\
\text { experience gained in waste removal operations to } \\
\text { date. The additional inventory provided by the } \\
\text { ancillary equipment is based on operational history at } \\
\text { the tank farms. The assumed sludge density is based } \\
\text { on measurements of sludge retrieved for development } \\
\text { of the DWPF. }\end{array}$ \\
\hline Page 4-11 & $\begin{array}{l}\text { For the purposes of this residual radionuclide } \\
\text { inventory, } 1000 \mathrm{~L} \text { ( } 264 \text { gal) of contaminated } \\
\text { ETF influent is assumed to remain in the ETF } \\
\text { Receiving Tank after D\&D activities for the } \\
\text { tank are completed. }\end{array}$ & $\begin{array}{l}\text { The residual radionuclide inventory is based on the } \\
\text { design and operational history of the tanks and the } \\
\text { SRS experience in cleaning HLW tanks. }\end{array}$ \\
\hline
\end{tabular}




\begin{tabular}{|c|c|c|}
\hline & $\begin{array}{l}\text { Using the dimensions of the ETF Basins and a } \\
\text { conservative estimate of } 7.6 \mathrm{~cm} \text { ( } 3 \text { in) of } \\
\text { sediment left in the basins, the residual } \\
\text { radionuclide contribution of ETF Basins is less } \\
\text { than } 1 \mathrm{Ci} \text {; therefore, the contribution is } \\
\text { insignificant and the ETF Basins have not been } \\
\text { included in this inventory estimate. }\end{array}$ & $\begin{array}{l}\text { It was assumed that closure of the ETF basins would } \\
\text { allow no more than three inches of sediment to remain } \\
\text { in the basins. Using the dimensions of the basins and } \\
\text { the three-inch thickness, as well as the concentration } \\
\text { of radionuclides observed in the sediment, the } \\
\text { sediment could contain no more than } 1 \text { curie of } \\
\text { radioactivity. Thus, the basins were screened from } \\
\text { further consideration. }\end{array}$ \\
\hline Page 4-12 & $\begin{array}{l}\text { For the purposes of this residual radionuclide } \\
\text { inventory estimate, the amount of residual } \\
\text { radionuclides associated with the process } \\
\text { sewer lines was calculated by Mr. Clifford } \\
\text { Cole, Sr. (Cole } 1996 \mathrm{c}) \text {. Mr. Cole } \\
\text { conservatively assumed that the highest } \\
\text { contamination level reported represents a } \\
\text { homogenous concentration of radionuclides in } \\
\text { the soil along each sewer line. Mr. Cole also } \\
\text { assumed that each sewer line is } 1524 \mathrm{~m}(5,000 \\
\mathrm{ft} \text { ) long, the excavation is } 3 \mathrm{~m}(10 \mathrm{ft}) \text { wide by } 3 \\
\mathrm{~m}(10 \mathrm{ft}) \text { deep, and the soil density is } 1920 \\
\mathrm{~kg} / \mathrm{m}^{3}\left(120 \mathrm{lb} / \mathrm{ft}^{3}\right) \text {. }\end{array}$ & $\begin{array}{l}\text { The highest observed contamination was imputed to } \\
\text { all of the soil associated with the sewer line. The } \\
\text { dimensions of the sewer line were conservatively } \\
\text { assigned. }\end{array}$ \\
\hline Page 4-13 & $\begin{array}{l}\text { For the purposes of this residual radionuclide } \\
\text { inventory estimate, } 25 \mathrm{Ci} \text { of alpha emitters and } \\
10 \mathrm{Ci} \text { of beta/gamma emitters will remain in } \\
\text { each tank after they have been emptied and } \\
\text { decontaminated For these four tanks, a total } \\
\text { inventory of } 100 \mathrm{Ci} \text { of alpha emitters and } 40 \mathrm{Ci} \\
\text { of beta/gamma emitters is assumed. The alpha } \\
\text { activity is assumed to be composed of } 40 \\
\text { percent }{ }^{244} \mathrm{Cm}, 50 \text { percent }{ }^{238} \mathrm{Pu} \text {, and } 10 \text { percent } \\
{ }^{239} \mathrm{Pu} \text {. The beta/gamma activity is assumed to } \\
\text { be due to only }{ }^{137} \mathrm{Cs} \text {. }\end{array}$ & $\begin{array}{l}\text { The residual inventory is based on the maximum } \\
\text { observed concentration of radionuclides in the tanks } \\
\text { and the estimated volume of residual material. The } \\
\text { isotopic distribution of alpha emitters is based on } \\
\text { analysis of material removed from the tanks. The } \\
\text { assignment of the beta/gamma activity to only }{ }^{137} \mathrm{Cs} \\
\text { was derived from the remediation work plans. The } \\
\text { review team challenged this assignment. A revised } \\
\text { assignment, based on fission product yields, is } \\
\text { provided in the response to Condition } 3 \text {. }\end{array}$ \\
\hline \multicolumn{3}{|c|}{ Section 4.1.3 S Area } \\
\hline Page 4-14 & $\begin{array}{l}\text { For the purposes of this residual radionuclide } \\
\text { estimate, } 3,785 \mathrm{~L} \text { ( } 1000 \text { gal) of typical DWPF } \\
\text { sludge slurry is assumed to remain in the } \\
\text { DWPF canyon building and } 189 \mathrm{~L} \text { ( } 50 \text { gal) of } \\
\text { typical DWPF sludge slurry is assumed to } \\
\text { remain in the Low Point Pump Pit after D\&D } \\
\text { activities are completed. }\end{array}$ & $\begin{array}{l}\text { The volume of residual waste in the DWPF and the } \\
\text { Low Point Pump Pit is based on the design of the } \\
\text { facilities and operational history to date. }\end{array}$ \\
\hline \multicolumn{3}{|c|}{ Section 4.1.5 Spills within the GSA } \\
\hline Page 4-14 & $\begin{array}{l}\text { For the purposes of this residual radionuclide } \\
\text { inventory estimate, all spills with an activity of } \\
\text { less than one Curie are considered to be } \\
\text { insignificant and have not been included. }\end{array}$ & $\begin{array}{l}\text { One Curie is a very small fraction of the total residual } \\
\text { radioactive material in the significant sources (those } \\
\text { listed in Table } 4.4-2 \text { ), thus, it was judged appropriate } \\
\text { to neglect sources less than one Curie. }\end{array}$ \\
\hline
\end{tabular}




\begin{tabular}{|c|c|c|}
\hline \multicolumn{3}{|c|}{ Section 4.1.6 Other RCRA/CERCLA Sites } \\
\hline \multirow[t]{2}{*}{ Page 4-16 } & $\begin{array}{l}\text { During the course of work on the Composite } \\
\text { Analysis, management determined that a } \\
\text { separate disposal facility for Environmental } \\
\text { Restoration waste was not warranted. The } \\
\text { inventories for the four facilities described } \\
\text { above were added to that of the E-Area } \\
\text { trenches. }\end{array}$ & $\begin{array}{l}\text { Since a separate disposal facility for ER waste would } \\
\text { not be built, it was assumed that the waste originally } \\
\text { assumed to be consigned to the ER disposal facility } \\
\text { would be disposed in the E-Area trenches. }\end{array}$ \\
\hline & $\begin{array}{l}\text { The sediments in the streams that bound the } \\
\text { GSA, Four Mile Branch and Upper Three } \\
\text { Runs, have potentially been contaminated with } \\
\text { radionuclides'released to the environment } \\
\text { during operations at the SRS. As with other } \\
\text { potential sources of radioactive material, only } \\
\text { the sediments within the GSA are considered } \\
\text { because it is those sources that could influence } \\
\text { decisions regarding operations of the LLW } \\
\text { disposal facilities. }\end{array}$ & $\begin{array}{l}\text { Since the focus of the CA is the management of the } \\
\text { active LLW disposal facilities, it was assumed that } \\
\text { only those sources within the GSA would influence } \\
\text { decisions on the operation of the LLW disposal } \\
\text { facility. If a source outside the GSA were to } \\
\text { contribute significantly to the CA dose, the actions } \\
\text { taken would be to remediate the source rather than to } \\
\text { alter operations of the LLW disposal facility. }\end{array}$ \\
\hline \multicolumn{3}{|c|}{ Section 4.2 Excluded Sources } \\
\hline \multirow[t]{3}{*}{ Page 4-17 } & $\begin{array}{l}\text { Facilities that have never been associated with } \\
\text { the processing, management, or disposal of } \\
\text { radioactive materials or waste such as the } \\
\text { Burma Road Rubble Pit, the H-Area } \\
\text { Acid/Caustic Basin, and the } 284-10 \mathrm{~F} \\
\text { Maintenance Shop. Such facilities are assumed } \\
\text { to be free of radionuclide contamination. }\end{array}$ & $\begin{array}{l}\text { Operational histories of each facility on the SRS are } \\
\text { known. For those facilities that are known not to have } \\
\text { radioactive material, it was judged reasonable to } \\
\text { exclude them from the CA. }\end{array}$ \\
\hline & $\begin{array}{l}\text { Administration buildings such as offices, } \\
\text { control rooms, laundry rooms, or clothing } \\
\text { change rooms. Although these facilities may } \\
\text { support other facilities that manage or dispose } \\
\text { of radioactive materials or waste, sufficient } \\
\text { controls are assumed to be in place to ensure } \\
\text { that these facilities are free of radionuclide } \\
\text { contamination. }\end{array}$ & $\begin{array}{l}\text { Radiological control requirements to protect workers } \\
\text { ensure that such facilities will have little, if any, } \\
\text { residual radioactive material. }\end{array}$ \\
\hline & $\begin{array}{l}\text { Temporary storage facilities such as material } \\
\text { staging areas, waste storage buildings or pads, } \\
\text { or equipment storage areas. These facilities are } \\
\text { assumed to be free of radionuclide } \\
\text { contamination because either the probability of } \\
\text { radioactive contamination is low or they can be } \\
\text { completely decontaminated of all residual } \\
\text { radionuclides. }\end{array}$ & $\begin{array}{l}\text { Such facilities are unlikely to have been contaminated } \\
\text { to any extent. Since the facilities are temporary } \\
\text { storage or staging areas, the probability of leaking } \\
\text { containers is small. Since they are storage facilities, } \\
\text { radiological control requirements ensure periodic } \\
\text { surveillance and clean-up of any released radioactive } \\
\text { material. }\end{array}$ \\
\hline Page 4-17 & $\begin{array}{l}\text { Radionuclides reported as "Gross Alpha" and } \\
\text { "Other Alpha" are assumed to be }{ }^{239} \mathrm{Pu} \text {. }\end{array}$ & $\begin{array}{l}\text { This is based on isotopic analysis of samples. } \\
\text { Additionally, the activity due to }{ }^{238} \mathrm{Pu} \text { is assigned to } \\
{ }^{239} \mathrm{Pu} \text { to maximize the consequent dose (the half-life of } \\
{ }^{238} \mathrm{Pu} \text { is only } 88 \text { years, with plutonium's expected high } \\
\text { sorption on soil, the }{ }^{238} \mathrm{Pu} \text { would essentially decay } \\
\text { away before migrating to a point of public access. }\end{array}$ \\
\hline
\end{tabular}




\begin{tabular}{|c|c|c|}
\hline & $\begin{array}{l}\text { Radionuclides reported as "Non-Volatile Beta" } \\
\text { are assumed to be }{ }^{90} \mathrm{Sr} \text {. } \\
\text { Radionuclides reported as "Other Beta- } \\
\text { Gamma" are assumed to be }{ }^{137} \mathrm{Cs} \text {. }\end{array}$ & $\begin{array}{l}\text { These assumptions are based on facility safety } \\
\text { documentation. The review team challenged them. A } \\
\text { revised assignment, based on fission product yields, is } \\
\text { provided in the response to Condition } 3 \text {. }\end{array}$ \\
\hline & $\begin{array}{l}\text { Radionuclides reported as "Radium" are } \\
\text { assumed to be }{ }^{226} \mathrm{Ra} \text {. }\end{array}$ & $\begin{array}{l}\text { Because SRS has processed uranium rather than } \\
\text { thorium, "Radium" was assigned to }{ }^{226} \mathrm{Ra} \text {, which is a } \\
\text { component of the uranium decay chain, rather than } \\
{ }^{228} \mathrm{Ra} \text {, which is a component of the thorium decay } \\
\text { chain. }\end{array}$ \\
\hline \multicolumn{3}{|c|}{ Section 4.3 Transport Pathway Identification } \\
\hline \multirow[t]{2}{*}{ Page 4-24 } & $\begin{array}{l}\text { Factors that limit release of tritium to the } \\
\text { atmosphere are likewise expected to limit }{ }^{14} \mathrm{C} \\
\text { releases. }\end{array}$ & $\begin{array}{l}\text { Transport of tritium and }{ }^{14} \mathrm{C} \text { to the atmosphere is via } \\
\text { advection and/or diffusion of vapor species. Thus, } \\
\text { factors limiting these processes (e.g., solubility in } \\
\text { vadose zone moisture) for tritium will also limit }{ }^{14} \mathrm{C} \text {. }\end{array}$ \\
\hline & $\begin{array}{l}\text { Based on the above observations, it was not } \\
\text { considered credible that any doses due to the } \\
\text { atmospheric pathway could come within orders } \\
\text { of magnitude of the } 100 \mathrm{mrem} / \mathrm{yr} \text { dose } \\
\text { objective or the } 30 \mathrm{mrem} / \mathrm{yr} \text { dose constraint for } \\
\text { the maximally exposed individual. Therefore, } \\
\text { the atmospheric pathway was eliminated from } \\
\text { further consideration, as indicated in Figure } \\
4.3-1 \text {. }\end{array}$ & $\begin{array}{l}\text { The "above considerations" show that it is not } \\
\text { credible for the atmospheric pathway to contribute } \\
\text { significantly to the dose calculated to the maximally } \\
\text { exposed individual in the CA. }\end{array}$ \\
\hline \multicolumn{3}{|c|}{ Section 4.4.3 Source Term Estimates } \\
\hline Page 4-47 & $\begin{array}{l}\text { Existing solid waste sites were modeled for } \\
\text { their actual time of operation. These were } \\
1954 \text { to } 1972 \text { for the OBG and } 1972 \text { to } 1994 \\
\text { for the MWMF. Lysimeters were treated as } \\
\text { separate sources within the MWMF. The } \\
\text { MWMF and OBG were modeled without a } \\
\text { closure cap. The F- and H-Area Seepage } \\
\text { Basins were modeled as closed systems, } \\
\text { including a closure cap, beginning in } 1988 \text {. }\end{array}$ & $\begin{array}{l}\text { To reduce conservatism, development of the OBG and } \\
\text { MWMF source terms included consideration of their } \\
\text { actual time of operation. Since both facilities have a } \\
\text { detailed history of waste burials, the source term was } \\
\text { distributed over the operational period rather than } \\
\text { assuming it was emplaced at one point in time. } \\
\text { However, because the final closure of the OBG and } \\
\text { MWMF has not been determined, these facilities were } \\
\text { conservatively modeled without a closure cap. } \\
\text { The lysimeters, which are located within the MWMF, } \\
\text { had a shorter operational period than the MWMF. } \\
\text { Thus, they were modeled as separate sources within } \\
\text { the MWMF. } \\
\text { Since the F- and H-Area Seepage Basins have been } \\
\text { closed, they were modeled in their closed state. }\end{array}$ \\
\hline
\end{tabular}




\begin{tabular}{|c|c|c|}
\hline Page 4-49 & $\begin{array}{l}\text { Both high level waste tanks and solvent tanks } \\
\text { were represented as concrete monoliths, based } \\
\text { on the approved closure plans submitted to the } \\
\text { State of South Carolina. Each HLW tank was } \\
\text { modeled as containing the expected residual } \\
\text { radionuclide inventory after waste removal and } \\
\text { closure. Key assumptions were that the tanks } \\
\text { remain intact for } 300 \text { years and that infiltration } \\
\text { was reduced by the concrete. }\end{array}$ & $\begin{array}{l}\text { Since the tanks are made of thick steel, it was judged } \\
\text { that } 300 \text { years was a reasonably conservative life for } \\
\text { the tanks. Experience with the SRS lysimeters and } \\
\text { PA modeling show that concrete is an effective barrier } \\
\text { to infiltrating water. }\end{array}$ \\
\hline & $\begin{array}{l}\text { Process buildings, F- and H-Area Canyons, the } \\
\text { DWPF, the Sand Filters and the } 772-F \\
\text { laboratories, were modeled as a concrete slab, } \\
\text { with the footprint of the existing structure, } \\
\text { contaminated with the assumed inventory. No } \\
\text { cap was assumed for these facilities. }\end{array}$ & $\begin{array}{l}\text { For this initial iteration of the CA, with } \\
\text { decommissioning plans for such facilities not } \\
\text { available, these simplifying assumptions were judged } \\
\text { appropriate. }\end{array}$ \\
\hline & $\begin{array}{l}\text { The only spills of sufficient magnitude (total } \\
\text { activity }>1 \text { curie) to be considered in the CA } \\
\text { were associated with the high level waste tanks } \\
\text { (d'Entremont, 1988). The spill inventory was } \\
\text { added to the residual inventory of the tank } \\
\text { group within which the spill was located. }\end{array}$ & $\begin{array}{l}\text { This assumption was made to facilitate calculation. In } \\
\text { responding to Condition } 3 \text {, the flux to the water table } \\
\text { for each of the spills, independent of the residual } \\
\text { inventory of the tank group, was determined. }\end{array}$ \\
\hline \multicolumn{3}{|c|}{ Section 4.4.4 Excluded Source Terms } \\
\hline Page 4-50 & $\begin{array}{l}\text { The source term criterion developed as part of } \\
\text { the screening methodology is based on an all- } \\
\text { pathways dose analysis. The criterion defines } \\
\text { a magnitude of release to the water table, } \\
\text { below which associated impacts of the source } \\
\text { term are expected to be considerably less than } \\
1 \mathrm{mrem} / \mathrm{yr} \text {. } \\
\text { In order to develop this criterion, it was } \\
\text { assumed that releases to the water table were } \\
\text { not diminished by sorption or radioactive } \\
\text { decay during transport in the subsurface, such } \\
\text { that a release to the water table eventually } \\
\text { became a discharge to a stream. Thus, a } 1 \\
\mathrm{Ci} / \mathrm{yr} \text { release to the water table was considered } \\
\text { a } 1 \mathrm{Ci} / \mathrm{yr} \text { release to a stream. }\end{array}$ & $\begin{array}{l}\text { Screening methodology should be demonstrably } \\
\text { conservative. Since the performance objective for the } \\
\mathrm{CA} \text { is } 100 \mathrm{mrem} / \mathrm{year} \text {, it was felt that a screening } \\
\text { criterion of } 1 \% \text { of that limit was appropriate. Further, } \\
\text { to ensure conservatism and to facilitate the analysis, } \\
\text { no credit was taken for natural processes (sorption, } \\
\text { dispersion, radioactive decay) that would act to } \\
\text { diminish the radionuclide concentration during transit } \\
\text { from the source to the point of exposure. }\end{array}$ \\
\hline
\end{tabular}




\begin{tabular}{|c|c|c|}
\hline Page 4-66 & $\begin{array}{l}\text { Initially, the hypothetical individual was } \\
\text { assumed to obtain all drinking water ( } 730 \mathrm{~L} / \mathrm{yr} \text { ) } \\
\text { and all dietary fish ( } 19 \mathrm{~kg} / \mathrm{yr} \text { ) from a location } \\
\text { on the Savannah River just downstream of the } \\
\text { Savannah River Site (near South Carolina } \\
\text { Highway } 301 \text { ). The individual was also } \\
\text { assumed to be involved in recreational } \\
\text { activities (boating and swimming) on the } \\
\text { Savannah River at this location throughout the } \\
\text { year. Flow of the Savannah River at this } \\
\text { location is assumed to be } 4000 \text { cfs, which is } \\
\text { considerably lower than the average flow rate } \\
\text { of } 10,500 \text { cfs at this location, and thus provides } \\
\text { an additional degree of conservatism in the } \\
\text { calculated doses since dilution is } \\
\text { underestimated. }\end{array}$ & $\begin{array}{l}\text { Screening methodology should be demonstrably } \\
\text { conservative. Even though it is unrealistic to think } \\
\text { that an individual would obtain his entire drinking } \\
\text { water supply from the river, this assumption is } \\
\text { demonstrably conservative. The assumption that the } \\
\text { individual consumes the average amount of fish for } \\
\text { this region of the country is reasonable. However, to } \\
\text { provide conservatism in the screening methodology, it } \\
\text { was assumed that all of the fish were obtained from } \\
\text { the Savannah River. Similarly, a conservatively low } \\
\text { average flow rate was assumed for the river. }\end{array}$ \\
\hline Page 4-67 & $\begin{array}{l}\text { It is highly improbable, however, that an actual } \\
\text { dose would approach } 1 \mathrm{mrem} / \mathrm{yr} \text { at this release } \\
\text { rate, given the number of conservative } \\
\text { assumptions incorporated in development of } \\
\text { this criterion. }\end{array}$ & $\begin{array}{l}\text { The conservative assumptions include using flow rates } \\
\text { about a factor of two lower than average flows and } \\
\text { using the radionuclide with the highest calculated dose } \\
\text { per curie released to represent all radionuclides. }\end{array}$ \\
\hline & $\begin{array}{l}\text { The release criterion of } 10^{-4} \mathrm{Ci} / \mathrm{yr} \text { was applied } \\
\text { in two ways. If the total release of all sources } \\
\text { of a particular radionuclide to the water table } \\
\text { was less than } 10^{-4} \mathrm{Ci} / \mathrm{yr} \text { during the } 1000-\mathrm{yr} \\
\text { assessment period (Table } 4.4-5 \text { ), then that } \\
\text { radionuclide was neglected for all sources in } \\
\text { subsequent transport and dose calculations. In } \\
\text { some cases, however, release of a radionuclide } \\
\text { with multiple sources was greater than } 10^{-4} \\
\mathrm{Ci} / \mathrm{yr} \text { from a few sources, but much less than } \\
10^{-4} \mathrm{Ci} / \mathrm{yr} \text { from others. In those cases, only the } \\
\text { sources characterized by releases of the } \\
\text { radionuclide greater than } 10^{-4} \mathrm{Ci} / \mathrm{yr} \text { were } \\
\text { addressed. The results are summarized in } \\
\text { Table } 4.4-6 \text {. }\end{array}$ & $\begin{array}{l}\text { Since the screening criterion of } 10^{-4} \mathrm{Ci} / \mathrm{yr} \text { was } \\
\text { developed on the basis that such a release could result } \\
\text { in a dose of no more than } 1 \mathrm{mrem} / \text { year }(1 \% \text { of the } \\
\text { dose limit), it is clear that, if the total release of a } \\
\text { particular radionuclide from all sources is less than the } \\
\text { criterion, then the radionuclide cannot contribute a } \\
\text { significant fraction of the dose limit and should be } \\
\text { neglected. In cases where the total release from all } \\
\text { sources exceeds the criterion, but only a few sources } \\
\text { cause the criterion to be exceeded, the other sources } \\
\text { can be appropriately neglected. }\end{array}$ \\
\hline \multicolumn{3}{|c|}{ Section 5.1 Performance Analysis, Hydrologic Model } \\
\hline Page $5-4$ & $\begin{array}{l}\text { Because these streams incise this unit, the } \\
\text { remaining groundwater moves downward } \\
\text { across the Gordon confining unit. Therefore, } \\
\text { these streams provide natural boundary } \\
\text { conditions for most of the UTR aquifer, and } \\
\text { were prescribed as discharge regions in the } \\
\text { groundwater model. On the west side of the } \\
\text { unit, hydraulic head values from a contour map } \\
\text { of measured groundwater elevations are } \\
\text { prescribed in lieu of natural flow boundaries. }\end{array}$ & $\begin{array}{l}\text { The western side of the model domain does not have a } \\
\text { natural flow boundary (e.g., it is not incised by } \\
\text { streams). Therefore, a constant-head boundary was } \\
\text { imposed, using the observed values for hydraulic head } \\
\text { in this region. The response to Condition } 2 \text { contains } \\
\text { additional assessment of the model boundary } \\
\text { conditions. }\end{array}$ \\
\hline
\end{tabular}


Section 5.3 Surface Water Concentrations

\begin{tabular}{|l|l|}
\hline Page 5-55 & $\begin{array}{l}\text { In order to calculate surface water } \\
\text { concentrations of radionuclides, annual flux of } \\
\text { radionuclides (Ci/yr) to the surface water body } \\
\text { must be specified, as well as flow rates of the } \\
\text { water body. Average concentrations at } \\
\text { specified downstream locations are calculated. } \\
\text { These concentrations do not account for } \\
\text { radionuclide decay during transit from the } \\
\text { point of discharge from groundwater, as this } \\
\text { decay is accounted for in the exposure and } \\
\text { dose calculations (Section 5.4). }\end{array}$ \\
\hline
\end{tabular}

Section 5.4 Exposure Scenarios

\begin{tabular}{|c|c|c|}
\hline Page 5-64 & $\begin{array}{l}\text { Reduction of radionuclide concentrations as a } \\
\text { result of sorption on sediment surfaces and } \\
\text { subsequent deposition, or as a result of water } \\
\text { treatment, are not accounted for in the } \\
\text { LADTAP XI model. Reduction due to } \\
\text { radioactive decay during transit time }\left(t_{w}\right) \\
\text { between discharge of radionuclides to the } \\
\text { streams and consumption of the water is } \\
\text { accounted for, based on an assumed average } \\
\text { transit time of } 1.5 \text { days. }\end{array}$ & $\begin{array}{l}\text { The assumption of no reduction of radionuclide } \\
\text { concentration as a result of sediment deposition or } \\
\text { water treatment is appropriate for tritium and is } \\
\text { conservative for other radionuclides. }\end{array}$ \\
\hline Page 5-65 & $\begin{array}{l}\text { Aquatic food consumption rates are assumed to } \\
\text { be a maximum of } 19 \mathrm{~kg} / \mathrm{yr} \text { for a hypothetical } \\
\text { individual, and } 9 \mathrm{~kg} / \mathrm{yr} \text { for the average member } \\
\text { of the population (Hamby } 1991 \mathrm{a} \text { ). Average } \\
\text { time between harvest and consumption of fish } \\
\text { and invertebrates is assumed to be } 2 \text { days, } \\
\text { during which radioactive decay may occur. }\end{array}$ & $\begin{array}{l}\text { The assumed consumption rates and the time between } \\
\text { fish harvesting and consumption are derived from } \\
\text { surveys of the regional population. }\end{array}$ \\
\hline Page 5-65 & $\begin{array}{l}\text { Exposure to contaminated shoreline sediments } \\
\text { is addressed in the LADTAP XL spreadsheet } \\
\text { model using the NRC Regulatory Guide } 1.109 \\
\text { equations for this pathway. A factor describing } \\
\text { deposition of radionuclides on sediment was } \\
\text { derived from empirical data obtained from the } \\
\text { Columbia River. A shore-width factor of } 0.2 \\
\text { (NRC 1977), also derived from experimental } \\
\text { data, is used to represent the fraction of } \\
\text { exposure to an infinite plane source estimated } \\
\text { for shoreline exposures. Unlike the Regulatory } \\
\text { Guide } 1.109 \text {, which assumes a buildup time of } \\
15 \text { years, the LADTAP XI spreadsheet } \\
\text { assumes the shoreline sediments have been } \\
\text { exposed to the calculated radionuclide } \\
\text { concentrations for } 40 \text { years }\left(t_{b}\right) \text {, corresponding } \\
\text { to the approximate operating period of SRS } \\
\text { facilities. }\end{array}$ & $\begin{array}{l}\text { The calculations are performed per NRC guidance } \\
\text { except where site-specific modification is appropriate } \\
\text { (e.g., longer time for sediment deposition } \\
\text { representative of SRS operational history). }\end{array}$ \\
\hline
\end{tabular}

Concentrations of radionuclides in surface water were calculated by simply diluting the annual flux of radionuclide from groundwater to the stream into the annual stream flow. Since the methodology for dose calculations from radionuclides in surface water incorporates radioactive decay during transit from the point of discharge, such decay was not accounted for in arriving at the surface water concentrations. 


\begin{tabular}{|c|c|c|}
\hline Page 5-66 & $\begin{array}{l}\text { In the LADTAP XI spreadsheet, the } \\
\text { hypothetical individuals and populations are } \\
\text { assumed to participate in swimming and } \\
\text { boating activities for periods of time }\left(t_{s}\right) \\
\text { consistent with those reported by Hamby } \\
\text { (1991b). The time spent by a hypothetical } \\
\text { individual swimming and boating is assumed } \\
\text { to be } 1.0 \times 10^{-3} \mathrm{yr}(8.9 \mathrm{hr}) \text { and } 2.4 \times 10^{-3} \mathrm{yr}(21 \\
\text { hr), respectively. The population is assumed to } \\
\text { spend } 18 \text { person-yr swimming and } 126 \text { person- } \\
\text { yr boating. }\end{array}$ & $\begin{array}{l}\text { The exposure times were selected to be consistent } \\
\text { with values obtained in surveys of the local populace. }\end{array}$ \\
\hline \multicolumn{3}{|c|}{ Section 6.1 Sensitivity Analysis, Sensitivity to Point of Assessment } \\
\hline Page 6-1 & $\begin{array}{l}\text { To understand the sensitivity of the results of } \\
\text { this analysis to the point of assessment, doses } \\
\text { associated with ingestion of water from Upper } \\
\text { Three Runs (UTR) and Fourmile Branch } \\
\text { (FMB) were calculated (Section } 5.5 \text { ). The } \\
\text { calculated drinking water doses assume an } \\
\text { ingestion rate of } 730 \mathrm{~L} / \mathrm{yr} \text {, which corresponds } \\
\text { to the rate for a maximally-exposed individual. } \\
\text { These doses do not include recreational } \\
\text { pathways (i.e., swimming, boating, shoreline) } \\
\text { or the fish consumption pathway because } \\
\text { recreation and fishing on these smaller streams } \\
\text { are not considered realistic activities. Average } \\
\text { flows of these streams at the GSA are } \\
\text { approximately } 6 \mathrm{~m}^{3} / \mathrm{s} \text { for UTR and } 0.4 \mathrm{~m}^{3} / \mathrm{s} \\
\text { for FMB. These low flows are not expected to } \\
\text { support large enough populations of fish to } \\
\text { constitute a significant fraction of the diet of } \\
\text { any user of the streams. }\end{array}$ & $\begin{array}{l}\text { The drinking water scenario, although unrealistic, was } \\
\text { selected to provide a simple, conservative analysis } \\
\text { that would illustrate the sensitivity to, and need for, } \\
\text { land use controls. }\end{array}$ \\
\hline \multicolumn{3}{|c|}{ Section 6.2 Sensitivity to Stream Flow } \\
\hline Page 6-3 & $\begin{array}{l}\text { Doses calculated at the points of assessment in } \\
\text { the mouths of UTR and FMB (Section 5.5.2) } \\
\text { are based on the average flow of these streams. } \\
\text { To assess the sensitivity of the results to } \\
\text { changes on stream flow, doses were also } \\
\text { calculated for the minimum and maximum } \\
\text { average annual flows }\end{array}$ & $\begin{array}{l}\text { Since doses are based on a year of exposure, it was } \\
\text { judged that the maximum annual flow rate was most } \\
\text { appropriate rather than the maximum flow rate over a } \\
\text { shorter period (e.g., instantaneous, monthly). }\end{array}$ \\
\hline
\end{tabular}




\begin{tabular}{|c|c|c|}
\hline on 7 & Chatlons & \\
\hline Page 7-3 & $\begin{array}{l}\text { The population doses calculated for the } \\
\text { ALARA process in this composite analysis } \\
\text { consider the populations served by the City of } \\
\text { Savannah Industrial and Domestic Water } \\
\text { Supply Plant (formerly Cherokee Hill Water } \\
\text { Treatment Plant), near Port Wentworth, } \\
\text { Georgia ( } 10,000 \text { persons), by the Beaufort- } \\
\text { Jasper Water Treatment Plant, near Beaufort, } \\
\text { South Carolina ( } 60,000 \text { persons), and the } \\
\text { population in a } 80-\mathrm{km} \text { (50-mile) radius of the } \\
\text { SRS which may participate in recreational and } \\
\text { commercial usage of the Savannah River } \\
\text { (620,000 persons). Exposure to radionuclides } \\
\text { of populations served by treatment plants is } \\
\text { assumed to take place as a result of drinking } \\
\text { water at concentrations found at the location of } \\
\text { the plants, which are approximately } 160 \mathrm{~km} \\
\text { downstream of the SRS. Exposure of the } \\
\text { population in the } 80 \text {-km radius is assumed to } \\
\text { occur as a result of harvest of aquatic fish and } \\
\text { invertebrates, and as a result of shoreline } \\
\text { activities, swimming, and boating. Ingestion of } \\
\text { contaminated water by members of this } \\
\text { population is assumed to be negligible. The } \\
\text { concentration of radionuclides in river water } \\
\text { for the } 80-\mathrm{km} \text { radius population is assumed to } \\
\text { be the concentration } 20 \mathrm{~km} \text { downstream of the } \\
\text { SRS (at Highway } 301 \text { ) - the same location } \\
\text { assumed for the maximally-exposed individual } \\
\text { (Section } 5.3 \text { ). }\end{array}$ & $\begin{array}{l}\text { The assumptions regarding river water usage for } \\
\text { community drinking water supplies are reasonable } \\
\text { because such use is currently taking place. } \\
\text { The exposure of the } 80-\mathrm{km} \text { population via a } \\
\text { recreational scenario (harvest of aquatic fish and } \\
\text { invertebrates, and as a result of shoreline activities, } \\
\text { swimming, and boating) is reasonable, based on } \\
\text { current activities of this population. }\end{array}$ \\
\hline Page 7-3/4 & $\begin{array}{l}\text { The flow rate of the Savannah River at the } \\
\text { location of these plants is assumed to be } \\
13,000 \mathrm{cfs} \text {, which is the estimated average flow } \\
\text { rate for this location (Hamby 1991b). A travel } \\
\text { time of } 4 \text { days for radionuclides leaving the } \\
\text { SRS before consumption is assumed, which } \\
\text { includes transit down the Savannah River and } \\
\text { residence in the water treatment system. } \\
\text { Individuals in the population exposed are } \\
\text { assumed to, on the average, consume water at a } \\
\text { rate of } 370 \mathrm{~L} / \mathrm{yr} \text {. }\end{array}$ & $\begin{array}{l}\text { The 4-day transit time is based on studies of the travel } \\
\text { time for conservative (i.e., non-sorbing) contaminants } \\
\text { from SRS streams to the Savannah River estuary. The } \\
\text { average water consumption rate is based on studies in } \\
\text { the literature where dietary intake was determined by } \\
\text { population surveys. }\end{array}$ \\
\hline
\end{tabular}




\begin{tabular}{|c|c|c|}
\hline \multicolumn{3}{|c|}{ Section 7.4.2 ALARA Analysis } \\
\hline Page 7-5 & $\begin{array}{l}\text { This maximum cost is calculated assuming } \\
\text { dose is reduced to zero, at an upper-end cost of } \\
\$ 10,000 \text { per person-rem and assuming a dose } \\
\text { integration time of one year. The many } \\
\text { conservative assumptions that went into } \\
\text { estimation of population dose further } \\
\text { maximizes this cost. }\end{array}$ & $\begin{array}{l}\text { For conservatism in the analysis (i.e., to maximize the } \\
\text { cost benefit of actions potentially taken), it was } \\
\text { assumed that the action would reduce the dose to zero, } \\
\text { rather than a fraction of the base case dose (i.e., } 25 \% \text { ). } \\
\text { Similarly, the maximum dollar equivalent of } \\
\text { collective dose, } \$ 10,000 \text { per person-rem, } \\
\text { recommended by USDOE was used to maximize the } \\
\text { calculated benefit. }\end{array}$ \\
\hline \multicolumn{3}{|c|}{$\begin{array}{l}\text { Notes: } \\
\text { Acronyms are generally not spelied out in the table due to space limitations. The Assumption column in the table may contain acronyms that are spelled out since this } \\
\text { column represents direct quotations from the } \mathrm{CA} \text { document. The following acronyms are used in the table. }\end{array}$} \\
\hline ALARA & \multicolumn{2}{|l|}{ As Low As Reasonably Achievable } \\
\hline $\mathrm{CA}$ & \multicolumn{2}{|l|}{$\begin{array}{l}\text { As Low As Reasonably Acnievabie } \\
\text { Composite Analysis }\end{array}$} \\
\hline CERCLA & \multicolumn{2}{|c|}{ Comprehensive Environmental Response, Compensation, and Liability Act } \\
\hline $\mathrm{D} \& \mathrm{D}$ & \multicolumn{2}{|c|}{ Decontamination and Demolition } \\
\hline USDOE & \multicolumn{2}{|l|}{ U.S. Department of Energy } \\
\hline DQO & \multicolumn{2}{|l|}{ Data Quality Objectives } \\
\hline DWPF & \multicolumn{2}{|l|}{ Defense Waste Processing Facility } \\
\hline EAV & \multicolumn{2}{|l|}{ E-Area Vaults } \\
\hline EPA & \multicolumn{2}{|l|}{ U.S. Environmental Protection Agency } \\
\hline FMB & \multicolumn{2}{|l|}{ Fourmile Branch } \\
\hline GSA & \multicolumn{2}{|l|}{ General Separations Area } \\
\hline HLW & \multicolumn{2}{|l|}{ High-Level Waste } \\
\hline HQ & \multicolumn{2}{|l|}{ Headquarters } \\
\hline ILT & \multicolumn{2}{|l|}{ Intermediate-Level Trench } \\
\hline LAW & \multicolumn{2}{|l|}{ Low-Activity Waste } \\
\hline LFRG & \multicolumn{2}{|l|}{ Low-Level Waste Facilities Federal Review Group } \\
\hline LLW & \multicolumn{2}{|l|}{ Low-Level Waste } \\
\hline MCL & \multicolumn{2}{|l|}{ Maximum Contaminant Level } \\
\hline NRC & \multicolumn{2}{|l|}{ U.S. Nuclear Regulatory Commission } \\
\hline OBG & \multicolumn{2}{|l|}{ Old Burial Ground } \\
\hline PA & \multicolumn{2}{|l|}{ Performance Assessment } \\
\hline RCRA & \multicolumn{2}{|l|}{ Resource Conservation and Recovery Act } \\
\hline ROD & \multicolumn{2}{|l|}{ Record of Decision } \\
\hline SRL & \multicolumn{2}{|l|}{ Savannah River Laboratory } \\
\hline SRS & \multicolumn{2}{|l|}{ Savannah River Site } \\
\hline SRTC & \multicolumn{2}{|l|}{ Savannah River Technology Center } \\
\hline UTR & \multicolumn{2}{|l|}{ Upper Three Runs } \\
\hline WSRC & \multicolumn{2}{|l|}{ Westinghouse Savannah River Company } \\
\hline
\end{tabular}




\section{$5.0 \quad$ Condition 5}

Disposition of all composite analysis review team comments (see attached enclosure Appendix $G$ \& H Review comments from Composite Analysis).

Appendices $\mathrm{G}$ and $\mathrm{H}$ from the Review Team Comments are not included with this SA. Table 5-1 is a compilation of the Review Team Comments taken from Appendix $H$ of their report. The table lists each comment and the action that will be taken on that comment. 
Table 5-1 Review Team Comment Disposition

\section{INVENTORY AND SOURCE TERM DEVELOPMENT}

\begin{tabular}{|c|c|c|}
\hline Com. No. & Comment & Action \\
\hline 1 & $\begin{array}{l}\text { The purpose of the CA is to determine the } \\
\text { affect from all potential sources of exposure } \\
\text { to the offsite receptor from sources that are } \\
\text { reasonably expected to have become } \\
\text { commingled with those from LLW disposal } \\
\text { operations. The identification of those } \\
\text { sources which contribute to the inventory } \\
\text { considered in the CA is not presented in a } \\
\text { clear or logical manner. As a result, the } \\
\text { exclusion of potential sources of radioactivity } \\
\text { outside of the GSA which could interact with } \\
\text { the wastes disposed of in E-Area and Z-Area } \\
\text { is not justified. Subsequent to the site visit, } \\
\text { additional material was provided (Letter from } \\
\text { W. L. Noll to Jeff Perry } 4 / 21 / 98 \text { ) to identify } \\
\text { the additional inventory in M-Area and Tim's } \\
\text { Branch which could contribute to the potential } \\
\text { future doses associated with the GSA. This } \\
\text { additional material does not appear to include } \\
\text { all of the potential sources in M-Area which } \\
\text { could contribute to the potential future doses } \\
\text { from the GSA. Most notable is the lack of } \\
\text { mention of the numerous tanks of sludge and } \\
\text { other radioactive materials in M-Area. } \\
\text { Consequently, there is no basis to conclude } \\
\text { the inventory has been rigorously estimated in } \\
\text { the CA. }\end{array}$ & $\begin{array}{l}\text { The inventory has been revised to } \\
\text { include all significant sources in } \\
A \text { and } M \text { Areas. See response to } \\
\text { Condition } 3 \text {. }\end{array}$ \\
\hline 2 & $\begin{array}{l}\text { In a number of cases, nuclides were } \\
\text { incorrectly reported or activity was assigned } \\
\text { to nuclides without sufficient justification. } \\
\text { Examples include: (d'Entremont, 1988) - For } \\
\text { the high level waste spills reported in this } \\
\text { reference, all curies were attributed to Cs-137 } \\
\text { and decayed using a } 30 \text { year half-life and } \\
\text { subsequently screened out. This is not } \\
\text { acceptable in light of the radionuclide } \\
\text { distribution that is known for the various high } \\
\text { level waste tanks. (Cole, 1996h) Table } 1.2 \text { - } \\
\text { The unassigned beta-gamma activity was not } \\
\text { accounted for in the Residual Radionuclide } \\
\text { Summary for the spill at Tank } 37 \text {. (Cole, } \\
\text { 1996d) - The source term summary charts } \\
\text { given in this reference do not correlate with } \\
\text { the column in the Residual Radionuclide } \\
\text { Inventory report that represents the source }\end{array}$ & $\begin{array}{l}\text { The inventory has been revised to } \\
\text { include all radionuclides in } \\
\text { sources that had been assigned to } \\
\text { only }{ }^{90} \mathrm{Sr} \text { and }{ }^{137} \mathrm{Cs} \text {. See response } \\
\text { to Condition } 3 \text {. }\end{array}$ \\
\hline
\end{tabular}




\begin{tabular}{|c|c|c|}
\hline Com. No. & Comment & Action \\
\hline & term for the Soil/Debris Consolidated Facility. & \\
\hline 3 & $\begin{array}{l}\text { The source term for the Old Burial Grounds is } \\
\text { stated to be the COBRA database. While it is } \\
\text { understood that the ER report titled "Source } \\
\text { Term for the Old Radioactive Waste Burial } \\
\text { Ground (ORWBG)-Savannah River Site } \\
\text { WSRC-RP-97-0119 was issued in October } \\
1997 \text { - and hence was unavailable for the } \\
\text { development of the CA, this should be used as } \\
\text { it provides a much more in-depth analysis and } \\
\text { justification for the source term used. In any } \\
\text { future use of this data however, it should be } \\
\text { explained how the Constituents of Interest } \\
\text { (COI) were derived. The stated COIs are not } \\
\text { the same as the radionuclides that the CA } \\
\text { determines to be the principle contributors to } \\
\text { dose. The differences need to be justified. }\end{array}$ & $\begin{array}{l}\text { Per CA maintenance, will address } \\
\text { this and other applicable } \\
\text { estimates of OBG inventory, as } \\
\text { well as revisions of other source } \\
\text { inventories, during the next } \\
\text { revision of the CA }\end{array}$ \\
\hline 4 & $\begin{array}{l}\text { Assumptions regarding the radionuclide } \\
\text { distribution and its' completeness are stated } \\
\text { with no justification in numerous places } \\
\text { throughout the document. The lack of clearly } \\
\text { stated assumptions and justifications severely } \\
\text { undermines the credibility of the analysis. The } \\
\text { use of assumptions is of special significance } \\
\text { to the high-level waste tanks. The heel } \\
\text { remaining in the tanks is likely to be a } \\
\text { significant contributor to the overall } \\
\text { radionuclide inventory for the GSA. The CA } \\
\text { does not provide a justification to support the } \\
\text { heel estimates in the CA as conservative } \\
\text { estimates. }\end{array}$ & See response to Condition 4 . \\
\hline 5 & $\begin{array}{l}\text { The CA includes a review of the inventory of } \\
\text { radionuclides considered and not considered. } \\
\text { The initial list of radionuclides to be } \\
\text { considered is based on the existing records, } \\
\text { which are associated with some uncertainty. } \\
\text { The estimates included in the analysis range } \\
\text { from well justified disposal records from } \\
\text { recent disposals to best estimates from } \\
\text { process knowledge or knowledgeable } \\
\text { individuals. These latter estimates cannot be } \\
\text { justified beyond being the best information } \\
\text { available. }\end{array}$ & See response to Condition 2. \\
\hline$\overline{6}$ & $\begin{array}{l}\text { The estimates of inventories and radionuclides } \\
\text { in the CA appeared to be derived from } \\
\text { referenced documentation, but the } \\
\text { documentation in Cole, Hsu, Lux, and } \\
\text { Shappell is a compilation of notes and } \\
\text { assumptions. This approach attributes more }\end{array}$ & $\begin{array}{l}\text { Per CA maintenance, will address } \\
\text { this and other questions related to } \\
\text { estimates of inventory during the } \\
\text { next revision of the CA }\end{array}$ \\
\hline
\end{tabular}




\begin{tabular}{|c|c|c|}
\hline Com. No. & Comment & Action \\
\hline & $\begin{array}{l}\text { credibility to the references than is warranted. } \\
\text { Much of the referenced inventory material } \\
\text { should be presented in the CA as data } \\
\text { summaries or appendices, rather than being } \\
\text { regarded as referenceable documentation. }\end{array}$ & \\
\hline 7 & $\begin{array}{l}\text { The inventory information in the CA includes } \\
\text { extrapolations from known data. The degree } \\
\text { of justification to attributed to these } \\
\text { extrapolations ranges from well justified to } \\
\text { the best available estimates. }\end{array}$ & $\begin{array}{l}\text { Per CA maintenance, will address } \\
\text { this and other questions related to } \\
\text { estimates of inventory during the } \\
\text { next revision of the CA }\end{array}$ \\
\hline$\overline{8}$ & $\begin{array}{l}\text { The CA includes the effects of CERCLA in } \\
\text { the CA, but includes those agreements which } \\
\text { are prescribed by RODs, and those which are } \\
\text { expected to be included in RODs. The } \\
\text { speculative CERCLA actions included in the } \\
\text { CA may not be part of the ultimate RODs. In } \\
\text { discussions during the site visit, the potential } \\
\text { for this to occur was acknowledged, and } \\
\text { corrections were to be addressed as part of } \\
\text { CA maintenance. The CA maintenance plan } \\
\text { has not yet been developed. The inclusion of } \\
\text { speculative outcomes of the CERCLA process } \\
\text { results in the CA being a potentially } \\
\text { non-conservative representation of the site. } \\
\text { Similar assumptions were made with regard to } \\
\text { D\&D actions, where no binding agreements } \\
\text { exist at this time, but expected outcomes were } \\
\text { used for the CA. The use of assumptions is of } \\
\text { special significance to the high level waste } \\
\text { tanks. The heel remaining in the tanks and the } \\
\text { inventory left in the HLW piping systems are } \\
\text { likely to be significant contributors to the } \\
\text { overall radionuclide inventory for the GSA. }\end{array}$ & $\begin{array}{l}\text { The CA maintenance plan has } \\
\text { now been developed. The plan } \\
\text { requires, per USDOE Order, } \\
\text { annual reviews of the CA. The } \\
\text { annual reviews will capture } \\
\text { changes in CERCLA, as well as } \\
\text { other, actions from those assumed } \\
\text { in the CA. See the attached } \\
\text { maintenance plan. }\end{array}$ \\
\hline 9 & $\begin{array}{l}\text { The assignment of beta-gamma activity to } \\
\text { radionuclides in numerous places has not been } \\
\text { justified. The responses to comments } \\
\text { provided a great deal of the justification for } \\
\text { the problem areas noted. However, each } \\
\text { source term needs to be reviewed to ensure } \\
\text { that the document clearly provides the } \\
\text { rationale behind the assignment of these } \\
\text { isotopes. One example that still needs to be } \\
\text { addressed is found on Page } 4-4, \text { Old Solvent } \\
\text { Tanks (S1 -S22), the last sentence on this page } \\
\text { indicates that the beta-gamma activity is } \\
\text { assumed to be Cs-137. It is unclear why only } \\
\text { Cs-137 is assumed to be present and not } \\
\text { Sr-90. Both are beta emitting fission products } \\
\text { commonly found together. (This comment }\end{array}$ & See response to Condition 3 . \\
\hline
\end{tabular}




\begin{tabular}{|c|c|c|}
\hline Com. No. & Comment & Action \\
\hline & $\begin{array}{l}\text { was raised during the site visit). The same } \\
\text { comment applies to solvent tanks S23-S30, } \\
\text { S32, and the new solvent tanks H33-H36. }\end{array}$ & \\
\hline 10 & $\begin{array}{l}\text { Pg. } 4-42-{ }^{37} \mathrm{Cs} \text { is screened from further } \\
\text { consideration due to "All of these } \\
\text { radionuclides, with the exception of }{ }^{126} \mathrm{Sn} \text { and } \\
{ }^{90} \mathrm{Sr} \text {, are fairly short-lived and were excluded } \\
\text { from further consideration in the Composite } \\
\text { Analysis." }{ }^{137} \mathrm{Cs} \text { is not a short-lived nuclide } \\
\text { compared to the other nuclides in this list. The } \\
\text { reason given verbally for excluding this } \\
\text { nuclide is due to the Kd value of } 100 \text {. It is not } \\
\text { apparent to the reader that this is a } \\
\text { conservative assumption since other nuclides } \\
\text { with Kd values in this range do appear to be } \\
\text { significant contributors to the dose in the } \\
\text { surface water. Both the F-Area and the } \\
\text { H-Area tank farms appear to be sufficiently } \\
\text { close to surface water that it is not unrealistic } \\
\text { to expect to see Cs contamination in the FMB } \\
\text { over the course of the compliance period. } \\
\text { Cs- } 137 \text { has already been detected in the } \\
\text { surface water of FMB from the F- and H-Area } \\
\text { Seepage Basins and the OBG. This existing } \\
\text { source has been screened out because it does } \\
\text { not pose a significant dose today. The analysis } \\
\text { should determine the dose for the next } 1000 \\
\text { years not just over the short term. }\end{array}$ & See the response to Condition 4 . \\
\hline 11 & $\begin{array}{l}\text { Comment resolutions provided, some. } \\
\text { rationale for determining that the D\&D source } \\
\text { term was comprehensive. However, it is still } \\
\text { unclear what facilities will undergo D\&D in } \\
\text { place and which facilities will be disposed in } \\
\text { the E-Area Vaults. A complete description of } \\
\text { the long term planning for each facility that } \\
\text { will dispose of waste in the active LLW } \\
\text { disposal facility needs to be included. The } \\
\text { information needs to be presented in such a } \\
\text { way that the reviewer can determine that the } \\
\text { entire source term from a facility will be } \\
\text { accounted for. }\end{array}$ & $\begin{array}{l}\text { Per the CA maintenance plan, } \\
\text { which is now developed, the } \\
\text { annual CA review will require } \\
\text { comparison of assumed D\&D } \\
\text { source terms with D\&D actions } \\
\text { or plans. If there is a significant } \\
\text { revision, a special analysis will be } \\
\text { required. See the attached } \\
\text { maintenance plan. }\end{array}$ \\
\hline$\overline{12}$ & $\begin{array}{l}\text { (WSRC, 1996b) - The last sentence, 2nd } \\
\text { paragraph states that curies from fission } \\
\text { products increase curies, they do not } \\
\text { significantly increase consequences. This } \\
\text { source term was developed for the safety } \\
\text { analysis to determine a bounding accident, } \\
\text { however, this assumption is not conservative } \\
\text { with respect to the CA. Provide an estimate of }\end{array}$ & $\begin{array}{l}\text { This source term will be re- } \\
\text { evaluated in the next annual } \\
\text { review of the Composite } \\
\text { Analysis. }\end{array}$ \\
\hline
\end{tabular}




\begin{tabular}{|c|c|c|}
\hline Com. No. & Comment & Action \\
\hline & $\begin{array}{l}\text { the fission products that were not included in } \\
\text { the source term for these facilities. }\end{array}$ & \\
\hline 13 & $\begin{array}{l}\text { The document referred to for the nuclide } \\
\text { inventory and activity estimate of the S23-S30 } \\
\text { tanks is a series of spreadsheets and does not } \\
\text { provide explanatory text. In fact, many of the } \\
\text { documents referenced as supporting source } \\
\text { term development lack descriptions of the } \\
\text { assumptions used. The lack of assumptions } \\
\text { within the composite analysis and supporting } \\
\text { documentation make it impossible for the } \\
\text { reader to determine how the inventories are } \\
\text { bounded and what degree of conservatism is } \\
\text { built into the estimates. }\end{array}$ & See response to Condition 4 . \\
\hline 14 & $\begin{array}{l}\text { A more accurate method of determining the } \\
\text { residual inventory would be to use } \\
\text { information from D\&D activities that have } \\
\text { taken place at SRS, such as BLDG } 232 \mathrm{~F} \text {. } \\
\text { Much of the building's debris was released for } \\
\text { disposal in sanitary landfills. In addition, } \\
\text { some of the waste streams at SRS have been } \\
\text { characterized by process knowledge by using } \\
\text { area contamination surveys to estimate the } \\
\text { contamination of waste removed from those } \\
\text { areas. It does not appear that any of the } \\
\text { historical information was used in validating } \\
\text { the inventory data that was used in the source } \\
\text { term development. }\end{array}$ & $\begin{array}{l}\text { The information from D\&D of } \\
232-\mathrm{F} \text { would only be pertinent to } \\
\text { other tritium facilities. As the CA } \\
\text { is maintained, refinement of } \\
\text { significant source terms, } \\
\text { including information from the } \\
\text { waste characterization program } \\
\text { will be done. See the attached } \\
\text { maintenance plan. }\end{array}$ \\
\hline 15 & $\begin{array}{l}\text { Page 5-16, last para., Existing residual activity } \\
\text { in the streams as a result of many years of } \\
\text { operational releases was not considered in this } \\
\text { analysis. Even though these operational } \\
\text { releases will cease in the future, some of the } \\
\text { radionuclides will remain in the sediment and } \\
\text { biota and therefore contribute to exposures of } \\
\text { offsite individuals. It is stated that it was not } \\
\text { included because this source will not } \\
\text { influence the waste management decision. } \\
\text { This should be reconsidered if a decision is } \\
\text { made by the LFRG regarding inclusion of all } \\
\text { sources on site. }\end{array}$ & $\begin{array}{l}\text { In response to Condition 1, the } \\
\text { CA is now focussed on a single } \\
\text { point of compliance at the UTR } \\
\text { mouth. Except for releases to } \\
\text { Tims Branch (which have been } \\
\text { considered in response to } \\
\text { Condition 3, and incorporated } \\
\text { into the response to Condition 1), } \\
\text { essentially no radionuclides have } \\
\text { been released to date to UTR. } \\
\text { See the response to Condition } 3 \text {. }\end{array}$ \\
\hline
\end{tabular}




\section{POINT OF ASSESSMENT AND PATHWAYS ANALYSIS}

\begin{tabular}{|c|c|c|}
\hline Com. No. & Comment & Action \\
\hline 16 & $\begin{array}{l}\text { This requirement has simply not been met. } \\
\text { The document does not clearly identify the } \\
\text { point of assessment. During questioning at the } \\
\text { site visit, the exact location of the point of } \\
\text { assessment was not clearly identified. At the } \\
\text { end of the discussion, Elmer Wilhite } \\
\text { explained how the point of assessment moved } \\
\text { during the preparation of the CA. Wherever } \\
\text { the point of assessment is, it is not justified. } \\
\text { Criteria } 6.2 .1 .1,6.2 .1 .2 \text {, and } 6.1 .1 .3 \text { have also } \\
\text { not been met. The point or points of public } \\
\text { access reasonably expected for future } \\
\text { members of the public for the time period of } \\
\text { the assessment have not been defined in the } \\
\text { existing CA. The point or points of } \\
\text { assessment that have been selected are not } \\
\text { supported by land use plans or reasonably } \\
\text { conservative assumptions that are justified. In } \\
\text { the CA, the less than conservative assumption } \\
\text { is made that land use controls will persist in } \\
\text { perpetuity, but documentation to support such } \\
\text { an assumption is based on a "Future Use } \\
\text { Report." Finally, any changes to the point of } \\
\text { assessment as a function of time have not } \\
\text { been discussed, identified, or justified. For } \\
\text { any of the possible points of assessment, such } \\
\text { as the A-Road bridge, the confluence of } \\
\text { Upper Three Runs/Four Mile Branch and the } \\
\text { Savannah River, Lower Three Runs, or the } \\
301 \text { bridge, there are inconsistencies in the } \\
\text { analysis. For example, the effect of M-Area is } \\
\text { not addressed in the discussion of Upper } \\
\text { Three Runs, and the effect of the production } \\
\text { reactors is not addressed in the discussion of } \\
\text { the } 301 \text { bridge. The only scenario considered } \\
\text { in the base case for the consumption of } \\
\text { drinking water is with the point of assessment } \\
\text { at the } 301 \text { bridge. These requirements suggest } \\
\text { the point of assessment needs to be clearly } \\
\text { presented and justified throughout the time } \\
\text { period of assessment in the CA. } \\
\text { The point of assessment is tied to the } \\
\text { exposure scenarios considered in the CA. } \\
\text { Consistency between the point of assessment } \\
\text { and exposure scenarios needs to be } \\
\text { maintained. Most importantly, the closest } \\
\text { point of public access which is a point of }\end{array}$ & $\begin{array}{l}\text { As determined by the LFRG, the } \\
\text { point of assessment is the mouth } \\
\text { of UTR. See the response to } \\
\text { Condition } 1 .\end{array}$ \\
\hline
\end{tabular}




\begin{tabular}{|c|c|c|}
\hline Com. No. & Comment & Action \\
\hline & $\begin{array}{l}\text { assessment needs to consider the drinking } \\
\text { water scenario. Postulating the closest } \\
\text { exposure scenario as a base case which } \\
\text { includes the consumption of drinking water at } \\
\text { the } 301 \text { bridge without the consideration of } \\
\text { contamination from Lower Three Runs, the } \\
\text { SRS production reactors, and Vogtle Nuclear } \\
\text { Power station is incomplete and inconsistent. } \\
\text { Similarly, a point of assessment that is closer } \\
\text { to the GSA that includes the consumption of } \\
\text { water should be considered. }\end{array}$ & \\
\hline 17 & $\begin{array}{l}\text { The use of a point of assessment at bridge } 301 \\
\text { does not seem to be conservative. The } \\
\text { rationale for this point is that there is a } \\
\text { gauging station at the bridge and hence an } \\
\text { accurate flow. The verbal statements that no } \\
\text { appreciable inflow into the river occurs } \\
\text { between the SRS site boundary and the bridge } \\
\text { has not been justified. With an annual rainfall } \\
\text { of } 124 \mathrm{~cm} / \mathrm{yr} \text { and considering normal runoff, } \\
\text { the argument that there are no major streams } \\
\text { flowing into the Savannah River between the } \\
\text { SRS boundary and the } 301 \text { bridge does not } \\
\text { provide adequate justification for the point of } \\
\text { assessment. }\end{array}$ & See the response to Condition 1 . \\
\hline 18 & $\begin{array}{l}\text { The supplemental information provided with } \\
\text { regards to the sensitivity to the ground water } \\
\text { divide seems to provide a good case for } \\
\text { establishing an offsite point of assessment } \\
\text { during the institutional control period. This } \\
\text { information needs to be included in the CA. } \\
\text { Alternate off-site points of assessment that } \\
\text { should be considered are the confluence of } \\
\text { Lower Three Runs with the Savannah River } \\
\text { and the SRS boundary at Steel Creek. }\end{array}$ & See the response to Condition 1 . \\
\hline 19 & $\begin{array}{l}\text { The guidance given for the preparation of the } \\
\text { CA states that dose "to a potential future point } \\
\text { of public access must be analyzed and the } \\
\text { resulting dose to a hypothetical future } \\
\text { member of the public determined." A } \\
\text { residential scenario (including drinking water) } \\
\text { at the mouth of FMB or UTR seems to be a } \\
\text { more realistic scenario for the out years. In the } \\
\text { near term, a residential scenario at the mouth } \\
\text { of Steel Creek just south of the current SR } \\
\text { boundary) seems to be defensible - this would } \\
\text { allow for an analysis of the impact of the } \\
\text { cumulative tritium dose. }\end{array}$ & See the response to Condition 1 . \\
\hline 20 & Section 2.3.7.2, page 2-24, paragraph 1, The & Hilton Head has not yet begun \\
\hline
\end{tabular}




\begin{tabular}{|c|c|c|}
\hline Com. No. & Comment & Action \\
\hline & $\begin{array}{l}\text { Hilton Head population, which will soon be } \\
\text { using Savannah River water, should be } \\
\text { included in the dose calculations. }\end{array}$ & $\begin{array}{l}\text { using river water. As water usage } \\
\text { at Hilton Head changes, the } \\
\text { impacts, if any, will be assessed } \\
\text { in accordance with the } \\
\text { maintenance plan (see the } \\
\text { attached plan). }\end{array}$ \\
\hline 21 & $\begin{array}{l}\text { Section } 2.4 .1 \text { Points of Assessment Although } \\
\text { this discussion has no answers per se, I offer } \\
\text { the following counter arguments to both the } \\
\text { scenarios and locations that were selected and } \\
\text { suggest that they are not only not conservative } \\
\text { but not all that meaningful to the question that } \\
\text { is being asked. If you put someone very far } \\
\text { away and expose them in a limited way for a } \\
\text { very short time than all sites look wonderful. } \\
\text { The assumption that land use will be restricted } \\
\text { perfectly for } 1000 \text { years is indeed optimistic at } \\
\text { best. Particularly when the source that is } \\
\text { referenced encourages as much recreational } \\
\text { use as possible among other things. For } \\
\text { example if parks etc are created then water } \\
\text { from either UTR, FMB or even groundwater } \\
\text { could be used for drinking. There could be } \\
\text { community gardens etc. Another example } \\
\text { residential use could indeed take place } \\
\text { opposite the site at the mouths of UTR and } \\
\text { FMB. This would increase not only the } \\
\text { possible exposure routes but also the duration } \\
\text { of these exposures. One is not trying to } \\
\text { predict the exact future here but it is important } \\
\text { to adequately bound the possibilities so that } \\
\text { sound management decisions can be made. } \\
\text { Placing the first all pathway location some } 20 \\
\text { km downstream of a very large site might } \\
\text { reflect the present worst case but by no } \\
\text { possible means would it reflect the future } \\
\text { worst case. Likewise assuming the nearest } \\
\text { population dose will be } 160 \text { km away for the } \\
\text { next } 1000 \text { years does not seem credible. }\end{array}$ & See the response to Condition 1. \\
\hline 22 & $\begin{array}{l}\text { Page 7-3, para. 7.4. 1, The future population } \\
\text { of the } 80 \text { kilometer }(\mathrm{km}) \text { area around SRS } \\
\text { may be underestimated. Should the } \\
\text { extrapolation of population, based on the } 1990 \\
\text { U.S. census data, be extended to the period of } \\
\text { time when the highest doses are cast? It is not } \\
\text { clear from the CA guidance that this is } \\
\text { acceptable or that additional uncertainty } \\
\text { analyses should be performed. }\end{array}$ & See response to Condition 1 . \\
\hline 23 & This requirement is not fully addressed in the & As determined by the LFRG, the \\
\hline
\end{tabular}




\begin{tabular}{|c|c|c|}
\hline Com. No. & Comment & Action \\
\hline & $\begin{array}{l}\text { CA. Reference to the comments relating to the } \\
\text { point of assessment should be made with } \\
\text { respect to this requirement. The scenarios } \\
\text { described in Sect. } 2.4 .2 \text { in the CA for the base } \\
\text { case utilize average flow rates, and the only } \\
\text { drinking water consumption is associated with } \\
\text { the point of assessment at the } 301 \text { bridge. The } \\
\text { discussion in Section } 5 \text { relating to the } \\
\text { ingestion of surface water makes reference to } \\
\text { the ingestion rate of } 730 \text { L/yr for a maximally } \\
\text { exposed individual and } 370 \text { L/yr for an } \\
\text { average adult. In the discussion that follows, } \\
\text { the rate selected for the analysis is not } \\
\text { identified. In Section } 2.4 .2, \text { a recreational } \\
\text { scenario is identified, which is supposed to be } \\
\text { described in Sect. 5.4. This description is } \\
\text { missing. As described in the site visit, the } \\
\text { recreational scenario includes all pathways } \\
\text { presented in Sect. } 5.4 \text { except the drinking } \\
\text { water pathway. } \\
\text { The PAs for E-Area and Z-Area considered } \\
\text { other exposure scenarios that were much } \\
\text { closer to the disposal facilities. In the CA, the } \\
\text { PA exposure scenarios were not discussed, } \\
\text { based on a future scenario that excluded } \\
\text { individuals from the SRS throughout the time } \\
\text { of assessment. The extended institutional } \\
\text { control period was based on a "Future Use } \\
\text { Project Report." This report was prepared for } \\
\text { the USDOE with a listing of } \\
\text { recommendations by stakeholders. The } \\
\text { closure plans for the GSA. E-Area, or Z-Area } \\
\text { were not provided. Land Use Plans for the } \\
\text { SRS were not provided. The CA Maintenance } \\
\text { Program was not provided. There were no } \\
\text { CERCLA RODs identified that included an } \\
\text { extended period of institutional control. The } \\
\text { exposure scenarios addressed in the CA were } \\
\text { not justified. }\end{array}$ & $\begin{array}{l}\text { point of assessment is the mouth } \\
\text { of UTR and the exposure scenario } \\
\text { is the recreational fisher person. } \\
\text { See the response to Condition } 1 .\end{array}$ \\
\hline 24 & $\begin{array}{l}\text { The CA used a value of } 23 \mathrm{hrs} / \mathrm{yr} \text { of shoreline } \\
\text { usage for that pathway. The reference } \\
\text { document (Hamby, D. M. } 1991 \mathrm{~b}-\mathrm{pg} \text {. 26) } \\
\text { refers to that figure as the exposure for the } \\
\text { average individual. It seems to be more } \\
\text { conservative to use the calculated maximum } \\
\text { individual shoreline usage of } 35 \mathrm{hrs} / \mathrm{yr} \text { for } \\
\text { calculating the dose to the maximally exposed } \\
\text { individual. }\end{array}$ & $\begin{array}{l}\text { Per CA maintenance, refinement } \\
\text { of exposure parameters to best } \\
\text { match the intent of the CA will be } \\
\text { done. See the attached } \\
\text { maintenance plan. }\end{array}$ \\
\hline
\end{tabular}




\begin{tabular}{|c|c|c|}
\hline Com. No. & Comment & Action \\
\hline 25 & $\begin{array}{l}\text { (Hamby, D. M. 1991b - pg. 3, 2nd column, } \\
\text { first full paragraph) - This paragraph excludes } \\
\text { pork and chicken from the analysis on the } \\
\text { basis of commercial feeding practices for } \\
\text { these animals. It is common for individuals to } \\
\text { let their hogs and chickens graze on a small } \\
\text { farm. The exclusion of these two sources of } \\
\text { potential uptake is not reasonable. }\end{array}$ & $\begin{array}{l}\text { Per CA maintenance, refinement } \\
\text { of exposure parameters to best } \\
\text { match the intent of the CA will be } \\
\text { done, including consideration of } \\
\text { animals raised on a small farm. } \\
\text { See the attached maintenance } \\
\text { plan. }\end{array}$ \\
\hline 26 & $\begin{array}{l}\text { Hamby, D. M. 1991b - pg. 9. At some point } \\
\text { during the CA maintenance period, it would } \\
\text { be reasonable to do a scoping assessment of } \\
\text { the radionuclide levels found in the American } \\
\text { Shad. }\end{array}$ & $\begin{array}{l}\text { Per CA maintenance, refinement } \\
\text { of exposure parameters to best } \\
\text { match the intent of the CA will be } \\
\text { done, including radionuclide } \\
\text { levels in various species such as } \\
\text { the American Shad. See the } \\
\text { attached maintenance plan. }\end{array}$ \\
\hline 27 & $\begin{array}{l}\text { To exclude a drinking water pathway is not } \\
\text { reasonable. In establishing a point of } \\
\text { assessment, a drinking water pathway must be } \\
\text { assumed as part of a complete residential } \\
\text { scenario. }\end{array}$ & $\begin{array}{l}\text { Per the LFRG's determination, } \\
\text { the CA point of assessment is the } \\
\text { mouth of UTR where, due to the } \\
\text { SRS land use plan, a residential } \\
\text { scenario is not likely. See the } \\
\text { response to Condition } 1 .\end{array}$ \\
\hline 28 & $\begin{array}{l}\text { Pg. 6-1, Section } 6.2, \text { 2nd paragraph, last } \\
\text { sentence - Since fish often feed at the mouths } \\
\text { of streams, it is not apparent that this last } \\
\text { statement is correct. It seems to be not } \\
\text { unreasonable to assume that there is a large } \\
\text { enough fish population to support a } \\
\text { significant fraction of the diet of a user when } \\
\text { considering the fish in the stream and those } \\
\text { located at the mouth of a stream. }\end{array}$ & $\begin{array}{l}\text { Per LFRG direction, the } \\
\text { recreational fishing scenario, as } \\
\text { defined in the CA, will be used. } \\
\text { See the response to Condition } 1 .\end{array}$ \\
\hline 29 & $\begin{array}{l}\text { The information describing the disposal site, } \\
\text { its location on the USDOE site, and its } \\
\text { proximity to other sources of radioactive } \\
\text { material presented in the CA is derived from } \\
\text { the PAs for E-Area and Z-Area. The sources } \\
\text { of radioactive material and the methodology } \\
\text { for assessing the migration of radionuclides } \\
\text { are described with comments regarding those } \\
\text { descriptions provided in previous comments. } \\
\text { As noted in these comments, some of the } \\
\text { potential sources of radioactivity, which could } \\
\text { interact with the disposal facilities, were not } \\
\text { described. The exposure scenarios following } \\
\text { transport and the point of assessment also are } \\
\text { discussed in previous comments. The } \\
\text { scenarios selected for the CA are } \\
\text { questionable. }\end{array}$ & $\begin{array}{l}\text { Per LFRG direction, the } \\
\text { recreational fishing scenario, as } \\
\text { defined in the CA, will be used at } \\
\text { the mouth of UTR. See the } \\
\text { response to Condition } 1 .\end{array}$ \\
\hline 30 & $\begin{array}{l}\text { Section } 6.3 \text { - The assumption that there will } \\
\text { be no public use of the SR site for the next }\end{array}$ & $\begin{array}{l}\text { Per USDOE guidance, the SRS } \\
\text { Land Use Plan provides sufficient }\end{array}$ \\
\hline
\end{tabular}




\begin{tabular}{|l|l|l|}
\hline Com. No. & Comment & Action \\
\hline $\begin{array}{l}1000 \text { years does not seem credible. Provide a } \\
\text { description of the types of controls to be } \\
\text { established to ensure that there will be no } \\
\text { public access to the SRS for } 1000 \text { years. }\end{array}$ & $\begin{array}{l}\text { basis for the assumption of no } \\
\text { public use. }\end{array}$ \\
\hline
\end{tabular}




\section{SENSITIVITY AND UNCERTAINTY ANALYSIS}

\begin{tabular}{|c|c|c|}
\hline Com. No. & Comment & Action \\
\hline 31 & $\begin{array}{l}\text { The determination of the important } \\
\text { parameters and assumptions which influence } \\
\text { the conclusions of the CA was not presented } \\
\text { in the CA. Several parameters and } \\
\text { assumptions were discussed during the site } \\
\text { visit which contribute to the conclusions of } \\
\text { the CA, but the overall importance of these } \\
\text { discussion topics, which are included in the } \\
\text { minutes of the site visit, to the conclusions of } \\
\text { the CA have not been established. Alternative } \\
\text { land uses and remedial actions are not } \\
\text { addressed in the uncertainty analysis. The CA } \\
\text { provides a set of possible outcomes for } \\
\text { CERCLA and RCRA and analyzes these } \\
\text { remedial actions. Changes in the CERCLA or } \\
\text { RCRA actions would be addressed as part of } \\
\text { the CA maintenance plan. }\end{array}$ & $\begin{array}{l}\text { The CA maintenance plan has } \\
\text { now been developed. The plan } \\
\text { requires, per USDOE Order, } \\
\text { annual reviews of the CA. The } \\
\text { annual reviews will capture } \\
\text { changes in CERCLA, as well as } \\
\text { other, actions from those assumed } \\
\text { in the CA. See the attached } \\
\text { maintenance plan. }\end{array}$ \\
\hline 32 & $\begin{array}{l}\text { The sensitivity and uncertainty of the results } \\
\text { is presented in the CA, but in a manner which } \\
\text { is not consistent with the requirement. } \\
\text { Alternative land uses are not considered; } \\
\text { however, the consumption of drinking water } \\
\text { from FMB and UTR is considered. The } \\
\text { sensitivity and uncertainty analysis considers } \\
\text { changes in the streamflow from an average } \\
\text { condition to a maximum or minimum } \\
\text { condition. The uncertainties in the inventories } \\
\text { for the disposal facility and other contributing } \\
\text { sources are not analyzed, and doses are not } \\
\text { calculated for ranges in the inventory } \\
\text { estimates. Alternative remedial actions were } \\
\text { not addressed in the analysis. Alternative } \\
\text { closure plans were not considered. Alternative } \\
\text { transport or site characteristics were not } \\
\text { considered. }\end{array}$ & $\begin{array}{l}\text { Alternative use of lands was } \\
\text { considered in Section } 6.3 \text { of the } \\
\text { CA. Uncertainty arising from } \\
\text { inventory values has been } \\
\text { assessed in response to Condition } \\
\text { 3. See the response to Condition } \\
\text { 3. }\end{array}$ \\
\hline 33 & $\begin{array}{l}\text { The major shortcoming to this section } \\
\text { (Chapter 6) on sensitivity analysis is the lack } \\
\text { of any work done related to the source term } \\
\text { and the unsubstantiated statement that the } \\
\text { source term is bounding and conservative. } \\
\text { Further, there does not seem to be any work } \\
\text { done in the release and fate and transport area } \\
\text { either. The expected analyses would include } \\
\text { attributes such as Kd values, release rates, } \\
\text { infiltration rates, etc. Lastly, the sensitivity of } \\
\text { the results to reasonable scenarios is not } \\
\text { adequate. On the one hand, the land use }\end{array}$ & $\begin{array}{l}\text { Per LFRG determination, the } \\
\text { recreational fishing scenario is to } \\
\text { be used at the mouth of UTR. } \\
\text { See the response to Condition } 1 \text {. } \\
\text { Uncertainty arising from } \\
\text { inventory values will be assessed } \\
\text { in response to Condition } 3 \text {. See } \\
\text { the response to Condition } 3 \text {. } \\
\text { Uncertainty with respect to } \\
\text { scenarios such as zucchini boat }\end{array}$ \\
\hline
\end{tabular}




\begin{tabular}{|c|c|c|}
\hline Com. No. & Comment & Action \\
\hline & $\begin{array}{l}\text { document encourages more recreational use of } \\
\text { the site, but on the other hand, the CA } \\
\text { document indicates that recreational use is not } \\
\text { realistic. The document needs to address more } \\
\text { clearly what uses there may be and what } \\
\text { doses may result. By encouraging use of the } \\
\text { land, there will be additional public exposure. } \\
\text { Recreational scenarios other than the } \\
\text { traditional swimming and boating might need } \\
\text { to be considered such as frog gigging and } \\
\text { zucchini boat racing. } \\
\text { The sensitivity area is especially important } \\
\text { since there are so many unknowns and of } \\
\text { course the future is unknown. The only way } \\
\text { to better understand the potential areas of } \\
\text { concern are with a thorough sensitivity and } \\
\text { uncertainty analysis. }\end{array}$ & $\begin{array}{l}\text { racing will be considered if such } \\
\text { scenarios are defined. }\end{array}$ \\
\hline 34 & $\begin{array}{l}\text { In Section } 6.5 \text {, an explicit sensitivity analysis } \\
\text { of the results of the CA to the source term } \\
\text { needs to be performed. Most of the data used } \\
\text { for source term information have not been } \\
\text { validated and hence it is not known whether } \\
\text { this represents a reasonable representation of } \\
\text { the source term. Lacking a validation of the } \\
\text { source term, a sensitivity analysis must be } \\
\text { conducted to show the reasonableness of the } \\
\text { analysis. }\end{array}$ & $\begin{array}{l}\text { Uncertainty arising from } \\
\text { inventory values has been } \\
\text { assessed in response to Condition } \\
\text { 3. See the response to Condition } \\
3 \text {. }\end{array}$ \\
\hline 35 & $\begin{array}{l}\text { In reviewing Section } 7.3 \text {, one really cannot } \\
\text { conclude much about the effect of } \\
\text { sensitivities, since such a limited amount of } \\
\text { sensitivity analysis was done. Also, it is not so } \\
\text { much the point of assessment that is likely to } \\
\text { be the most sensitive, but rather, it is how } \\
\text { long a, period of time that the assessment } \\
\text { must consider, and what the people are doing } \\
\text { there during that time period. Lastly, the } \\
\text { document once again cites the conservatism } \\
\text { of the analysis but gives the reader absolutely } \\
\text { no idea of the potential magnitude of such a } \\
\text { statement. For instance, does the analysis } \\
\text { overestimate the potential dose by a factor of } \\
2,10,1000,1,000,000 \text { etc. This needs to be } \\
\text { stated and justified. }\end{array}$ & $\begin{array}{l}\text { USDOE guidance specifies the } \\
\text { time of assessment as } 1,000 \\
\text { years. Quantification of the } \\
\text { degree of conservatism is not a } \\
\text { requirement. }\end{array}$ \\
\hline 36 & $\begin{array}{l}\text { With reference to the section entitled } \\
\text { "Sensitivity to Use of Land Not Permanently } \\
\text { Controlled by USDOE" (discussion on Page } \\
6-3 \text { ), although future use plans do not call for } \\
\text { release of the site for unrestricted use, and }\end{array}$ & $\begin{array}{l}\text { Effects of remediation activities } \\
\text { on hydrology in the GSA have } \\
\text { been documented in (SRT-EST- } \\
98-154 \text { ). These effects are } \\
\text { minimal and would not influence }\end{array}$ \\
\hline
\end{tabular}




\begin{tabular}{|c|c|c|}
\hline Com. No. & Comment & Action \\
\hline & $\begin{array}{l}\text { therefore, provide the opportunity for WSRC } \\
\text { to conclude that such scenarios as the use of a } \\
\text { drinking water well in the GSA are not } \\
\text { realistic, the sensitivity analysis should } \\
\text { reasonably assess the potential impact on the } \\
\text { flow system, and thereby the doses projected } \\
\text { in the CA, of plausible activities that could } \\
\text { occur even though the present site restrictions } \\
\text { continue. Rather than dismissing as unrealistic } \\
\text { any foreseeable change in land use (e.g., on } \\
\text { Page } 6-4, \text {,...large-scale irrigation is not } \\
\text { practiced..."), and concluding that no further } \\
\text { analysis is needed, it may be valuable to } \\
\text { determine what magnitude of local, on-site } \\
\text { land use changes would be necessary to alter } \\
\text { the flow system, the hydrologic boundaries } \\
\text { used in the models, and the assumptions } \\
\text { regarding natural barriers. It should be noted } \\
\text { that active remediation and disposal site } \\
\text { capping, which potentially have significant } \\
\text { impacts on the flow system, have only } \\
\text { recently been implemented. Over the next } \\
\text { several years, additional remediation, which } \\
\text { may involve pump-treat-reinject (PTR) and } \\
\text { capping, and other site activities that may } \\
\text { involve substantial use of water and surface } \\
\text { area in the GSA, could conceivably cause } \\
\text { some of the changes in local hydrology that } \\
\text { have been dismissed from further analysis in } \\
\text { this section. }\end{array}$ & $\begin{array}{l}\text { the CA results. See the response } \\
\text { to Condition } 2 .\end{array}$ \\
\hline 37 & $\begin{array}{l}\text { Reliance on recommendations included in a } \\
\text { future land use plan is not an acceptable } \\
\text { reason for not performing additional analyses } \\
\text { of the potential impacts on the flow system of } \\
\text { future land and water use changes. }\end{array}$ & $\begin{array}{l}\text { Per USDOE guidance, the Land } \\
\text { Use Plan is the basis for } \\
\text { projections of future land use. }\end{array}$ \\
\hline 38 & $\begin{array}{l}\text { Page 4-15, para. } 4.1 .6, \text { Recent events at SRS } \\
\text { within the Environmental Restoration } \\
\text { program have brought into question the } \\
\text { disposal location of waste resulting from } \\
\text { CERCLA actions. In particular, since disposal } \\
\text { of seepage basin wastes may not be going into } \\
\text { the E-Area soil trenches, should the analyses } \\
\text { be changed or should additional sensitivity } \\
\text { analyses be included? }\end{array}$ & $\begin{array}{l}\text { Changes in remedial actions or } \\
\text { planned actions must be assessed } \\
\text { in the CA annual review, as } \\
\text { mandated by the SRS CA } \\
\text { Maintenance Plan, which is } \\
\text { attached.. }\end{array}$ \\
\hline 39 & $\begin{array}{l}\text { Section 6.4 - A general description is given of } \\
\text { the effects of movement of the groundwater } \\
\text { divide and is expounded upon in the } \\
\text { supplemental information. The supplemental } \\
\text { information states that it is not credible for the }\end{array}$ & See response to Condition 2 . \\
\hline
\end{tabular}




\begin{tabular}{|c|c|c|}
\hline Com. No. & Comment & Action \\
\hline & $\begin{array}{l}\text { groundwater divide to move significantly. } \\
\text { Justification for this statement has not been } \\
\text { provided. No discussion is given of the } \\
\text { potential natural phenomenon that would } \\
\text { cause a shift in the groundwater divide. This } \\
\text { section needs to provide a discussion of the } \\
\text { various mechanisms that would cause it to } \\
\text { move and the likelihood of these scenarios. }\end{array}$ & \\
\hline 40 & $\begin{array}{l}\text { The sensitivity analysis (Section } 6.0 \text { ) should } \\
\text { be re-worked and expanded, based at a } \\
\text { minimum, on the re-analysis information } \\
\text { provided by WSRC in the } 4 / 21 / 98 \text { memo. } \\
\text { Table } 6.1 \text {-1 indicates that the peak dose at the } \\
\text { GSA for exposure to tritium through the } \\
\text { drinking water pathway is } 24 \text { mrem/year, } \\
\text { while the re-analysis estimates that it could be } \\
\text { as high as } 64 \text { mrem/year. The entire } \\
\text { sensitivity analysis should be carefully } \\
\text { revised and re-analyzed to clearly place upper } \\
\text { bounds on potential future doses. } \\
\text { A major objective of the sensitivity analysis } \\
\text { should be to set the direction for future studies } \\
\text { and analyses that could most effectively } \\
\text { reduce uncertainty in the overall CA. These } \\
\text { studies and analyses, which may be conducted } \\
\text { prior to completion of the technical review of } \\
\text { the CA or could be more appropriately } \\
\text { conducted as part of a CA maintenance } \\
\text { program, should be viewed as part of the } \\
\text { on-going effort to validate predictions of } \\
\text { future physical conditions and future } \\
\text { contaminant transport, and should be used to } \\
\text { substitute actual data for assumptions. The } \\
\text { value of the sensitivity analysis is the } \\
\text { quantification of the various levels of } \\
\text { uncertainty, which would provide direction on } \\
\text { prioritizing future studies, so as to reduce } \\
\text { uncertainty as much as possible, and thereby } \\
\text { effectively improve the quality of the CA. }\end{array}$ & $\begin{array}{l}\text { Per the LFRG, the CA has been } \\
\text { refocused to a single point of } \\
\text { assessment at the mouth of UTR, } \\
\text { see the response to Condition } 1 . \\
\text { The SRS CA Maintenance Plan, } \\
\text { which is attached, requires } \\
\text { continuous improvement of the } \\
\text { CA by test and research activities } \\
\text { and special analyses. }\end{array}$ \\
\hline 41 & $\begin{array}{l}\text { While attempts to justify the assumptions in } \\
\text { the CA have been made, previous comments } \\
\text { are directed toward these justifications. In } \\
\text { addition, the uncertainty analysis should } \\
\text { quantitatively examine the assumptions } \\
\text { associated with the inventory. Of particular } \\
\text { note are the potential ranges in inventory } \\
\text { which could be attributed to the various } \\
\text { radionuclides. Additionally, Stewart was }\end{array}$ & See response to Condition 3 . \\
\hline
\end{tabular}




\begin{tabular}{|c|c|c|}
\hline Com. No. & Comment & Action \\
\hline & $\begin{array}{l}\text { identified at the site visit as the reference } \\
\text { which was used to provide the activity } \\
\text { distributions for the curies reported to be } \\
\text { disposed of in the old burial ground, but } \\
\text { Stewart is not listed in the references in the } \\
\text { CA. So what was really used in the CA? } \\
\text { While not challenging the distributions } \\
\text { attributed to Stewart, the uncertainty analysis } \\
\text { should examine the range in results associated } \\
\text { with the range in the uncertainties in the } \\
\text { radionuclide distributions derived from } \\
\text { Stewart. }\end{array}$ & \\
\hline 42 & $\begin{array}{l}\text { Alternative land uses were not considered. } \\
\text { Perpetual institutional control of the SRS was } \\
\text { the only land use option considered in the CA. } \\
\text { In discussions at the SRS, other land } \\
\text { use-options were noted as possibilities to be } \\
\text { considered as part of a CA maintenance plan. } \\
\text { The CA maintenance plan was not provided. } \\
\text { Variations in radionuclide inventories, site } \\
\text { and facility characteristics, and transport } \\
\text { parameters were not considered in the } \\
\text { sensitivity and uncertainty analysis. } \\
\text { Consequently, bounding estimates of the } \\
\text { potential doses at the point of assessment for } \\
\text { the time period of assessment were not } \\
\text { provided in the CA. Alternative closure plans } \\
\text { were not considered and alternative site and } \\
\text { waste characteristics were not considered. } \\
\text { Bounding analyses were not provided to } \\
\text { provide some assurance that the dose } \\
\text { constraint and dose limit would not be } \\
\text { exceeded in the foreseeable future. }\end{array}$ & $\begin{array}{l}\text { Alternative land uses were } \\
\text { addressed in Section } 6.3 \text {. The } \\
\text { SRS CA Maintenance Plan, } \\
\text { which has now been developed } \\
\text { and implemented, requires an } \\
\text { annual review of the CA versus } \\
\text { changes in actions or plans with } \\
\text { respect to such things as closure } \\
\text { plans, etc. The maintenance plan } \\
\text { is attached. }\end{array}$ \\
\hline 43 & $\begin{array}{l}\text { Page } 6-3, \text { para. } 6.3 \text {, Since the guidance for a } \\
\text { composite analysis requires that reasonable } \\
\text { alternatives to land use be considered in the } \\
\text { sensitivity and uncertainty analyses, it appears } \\
\text { that at least one reasonable alternative has } \\
\text { been excluded - a resident living on site. The } \\
\text { SRS Future Land Use Plan has been approved } \\
\text { locally and transmitted to HQ, but it is not } \\
\text { clear if this plan will remain unchanged. It is } \\
\text { also unclear how this plan will be } \\
\text { implemented, (i.e. deed restrictions). }\end{array}$ & $\begin{array}{l}\text { The SRS Land Use Plan, per } \\
\text { USDOE guidance for the CA, } \\
\text { provides the basis for not } \\
\text { considering an on-site resident. }\end{array}$ \\
\hline 44 & $\begin{array}{l}\text { Page 6-6, Sensitivity to Source Term, states: } \\
\text { "...the assessment of sources other than the } \\
\text { two LLW disposal facilities used } \\
\text { conservative, bounding assumptions to assess } \\
\text { the maximum potential impact of these }\end{array}$ & $\begin{array}{l}\text { See the responses to Conditions } 3 \\
\text { and } 4 .\end{array}$ \\
\hline
\end{tabular}




\begin{tabular}{|c|c|c|}
\hline Com. No. & Comment & Action \\
\hline & $\begin{array}{l}\text { sources." } \\
\text { The bounding assumptions used in the } \\
\text { development and assessment of sources are } \\
\text { not described in the document. As such, the } \\
\text { conservatism in the development of source } \\
\text { terms is not apparent. With the document } \\
\text { lacking descriptions for the bounding } \\
\text { assumptions and the existing information not } \\
\text { being complete enough to determine a level of } \\
\text { certainty, it is difficult at best, to determine } \\
\text { what error factors or confidence intervals can } \\
\text { be associated with the calculated maximum } \\
\text { dose. }\end{array}$ & \\
\hline 45 & $\begin{array}{l}\text { An internal WSRC report entitled, "Impact of } \\
\text { F- and H-Area Pump-Treat-Reinject } \\
\text { Remediation Systems on the Old Radioactive } \\
\text { Waste Burial Ground, (SRT-EST-98-154)", } \\
\text { which was not used in the development of the } \\
\text { CA since the CA pre-dated this report, is an } \\
\text { analysis of the potential impact on the flow } \\
\text { system in the upper (water table) aquifer of } \\
\text { the active PTR systems in place at the F \& H } \\
\text { Areas and the cover recently installed at the } \\
\text { Old Burial Ground (OBG). The report } \\
\text { concludes, among other things, that these } \\
\text { remediation activities will affect the flow } \\
\text { system at F Area, E Area, and H Area, and } \\
\text { that some impacts will occur in the short term } \\
\text { (weeks and months), but other impacts will } \\
\text { not be realized for years. This report was } \\
\text { based strictly on a modeling analysis, which } \\
\text { was designed to account for broad impacts on } \\
\text { the flow system throughout a large area (i.e., } \\
\text { the entire GSA), but also to account for } \\
\text { relatively small scale impacts (i.e.. impacts on } \\
\text { water table elevations at each individual } \\
\text { extraction or injection well). } \\
\text { The additional information provided to the } \\
\text { review team by WSRC on } 4 / 21 / 98 \text { reviews } \\
\text { this report and concludes that there is } \\
\text { "potential" for the ground water divide to } \\
\text { change over time as a result of active } \\
\text { remediation in the GSA, but that the } \\
\text { magnitude of any such changes would be } \\
\text { small. This conclusion (and presumably the } \\
\text { decision not to explore this matter further) is } \\
\text { not technically justified for the following } \\
\text { reasons: }\end{array}$ & $\begin{array}{l}\text { Per LFRG direction, as } \\
\text { documented in response to } \\
\text { Condition } 1 \text {, the CA will consider } \\
\text { a single point of assessment at the } \\
\text { mouth of UTR. The bounding } \\
\text { effect of all sources migrating to } \\
\text { UTR is contained in the response } \\
\text { to Condition } 2 \text {. }\end{array}$ \\
\hline
\end{tabular}




\begin{tabular}{|c|c|c|}
\hline Com. No. & Comment & Action \\
\hline & 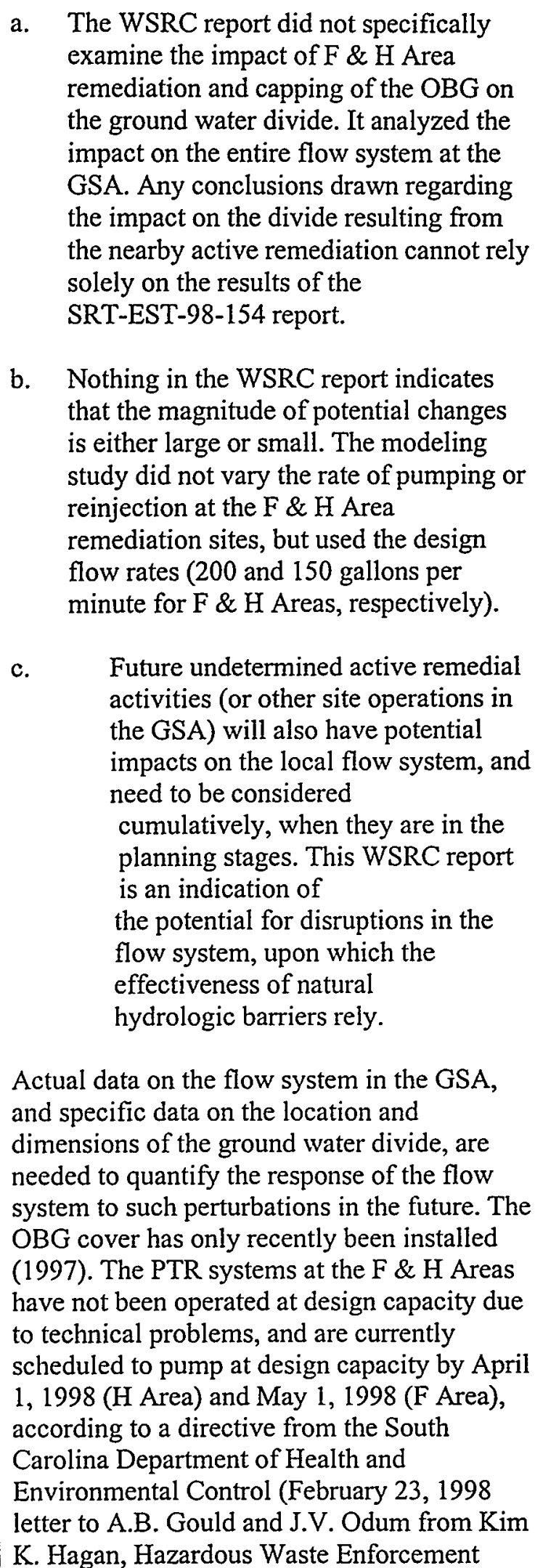 & \\
\hline
\end{tabular}




\begin{tabular}{|c|c|c|}
\hline Com. No. & Comment & Action \\
\hline & $\begin{array}{l}\text { Section, Bureau of Land and Waste } \\
\text { Management). Therefore, data needed to } \\
\text { validate conclusions drawn in this modeling } \\
\text { study are not currently available and probably } \\
\text { will not be for some months or years. When } \\
\text { such data (e.g., water table gradients and } \\
\text { elevations in the immediate vicinity of the } \\
\text { modeled location of the ground water divide) } \\
\text { becomes available, a study should be } \\
\text { performed to validate the results of the } \\
\text { modeling analysis included in the WSRC } \\
\text { report. Until such analyses are completed, it is } \\
\text { premature and therefore, not technically } \\
\text { supportable, to conclude that the magnitude of } \\
\text { changes to the location of the ground water } \\
\text { divide from local remediation activities will } \\
\text { be small. }\end{array}$ & \\
\hline 46 & $\begin{array}{l}\text { The issue of uncertainty in the ground water } \\
\text { divide should be treated more rigorously. } \\
\text { Uncertainties in the cause of the ground water } \\
\text { mound in H Area could impact flow } \\
\text { directions and rates. Modeling the mound } \\
\text { required reductions in horizontal conductivity } \\
\text { and flow rates which may not be real. Lack of } \\
\text { flux from the eastern edge of the model may } \\
\text { also cause the model to underestimate flow } \\
\text { rates. And the effect of the upward gradient in } \\
\text { the three S and Z area wells has not been } \\
\text { evaluated. Finally, there is a discrepancy } \\
\text { between the tritium dose calculated for all } \\
\text { contaminants reaching Four Mile Branch in } \\
\text { the CA sensitivity analysis ( } 29 \text { mrem/year, } \\
\text { page } 6-5 \text { ) and the Bounding Estimate of All } \\
\text { GSA Contaminants Migrating to Either of the } \\
\text { Streams provided to the review group via } \\
\text { FAX on April } 22,1998 \text { ( } 64 \text { mrem/year). } \\
\text { These observations, taken together. indicate } \\
\text { that the uncertainty in the model needs to be } \\
\text { further evaluated. }\end{array}$ & $\begin{array}{l}\text { Per LFRG direction, as } \\
\text { documented in response to } \\
\text { Condition } 1 \text {, the CA will consider } \\
\text { a single point of assessment at the } \\
\text { mouth of UTR. The bounding } \\
\text { effect of all sources migrating to } \\
\text { UTR is documented in the } \\
\text { response to Condition } 2 \text {. }\end{array}$ \\
\hline
\end{tabular}




\section{DATA QUALITY OBJECTIVES}

\begin{tabular}{|c|c|c|}
\hline Com. No. & Comment & Action \\
\hline 47 & $\begin{array}{l}\text { Section } 3.2 .3 \text { and elsewhere - There is a } \\
\text { statement in the last paragraph on page } 3-3 \\
\text { that begins "All estimates and assumptions ..." } \\
\text { Since the assumptions are critical to } \\
\text { understanding the worthiness, if you will, of } \\
\text { the estimates where are they documented and } \\
\text { what sanity checks were made of them? }\end{array}$ & See the response to Condition 4 . \\
\hline 48 & $\begin{array}{l}\text { Section 3.2.4 Spatial Boundaries - I question } \\
\text { the adequacy of the domain. For example why } \\
\text { were not sources on the other side of UTR } \\
\text { considered? And if your point of compliance } \\
\text { is at the } 301 \text { bridge why were not other on site } \\
\text { sources considered? }\end{array}$ & See the response to Condition 1 . \\
\hline 49 & $\begin{array}{l}\text { Page } 3-6, \text { Section } 3.2 .5: \text { there needs to be } \\
\text { more discussion provided on just what the } \\
\text { "personnel knowledgeable" about the various } \\
\text { waste streams provided and what they deemed } \\
\text { representative. The concern is from a } \\
\text { completeness standpoint. The nuclides of long } \\
\text { term concern are seldom the ones that cause } \\
\text { operational problems or show up on the near } \\
\text { term radar screen. Typically the only way } \\
\text { they are identified is by inference, scaling, } \\
\text { derivation etc. The steps taken to ensure a } \\
\text { complete inventory needs to be described. }\end{array}$ & See the response to Condition 3 . \\
\hline 50 & $\begin{array}{l}\text { Section } 4 \text { in general - As the source term } \\
\text { development is probably the most critical } \\
\text { component of the composite it is most } \\
\text { important that it be thorough, complete, } \\
\text { defensible, credible and technically sound. } \\
\text { There is not enough information provided to } \\
\text { answer any of these questions. For example, } \\
\text { two of the major potential sources, MWMF } \\
\text { and OBG, just reference a COBRA database. } \\
\text { No other information or discussion provided. } \\
\text { Other sources just reference an "e-mail } \\
\text { memorandum." Others like the Old Solvent } \\
\text { Tanks just "assume" an activity with no } \\
\text { explanation or justification. Then right on the } \\
\text { heel of this assumption another is made which } \\
\text { assigns entire groups of activity to one } \\
\text { nuclide, again with no explanation. }\end{array}$ & $\begin{array}{l}\text { See the responses to Conditions } 2 \text {, } \\
3 \text {, and } 4 \text {. }\end{array}$ \\
\hline 51 & $\begin{array}{l}\text { It is understood that a good portion of the } \\
\text { historic data regarding contributing source } \\
\text { terms is limited, and in accordance with the } \\
\text { April } 30,1996 \text { document, Guidance for a } \\
\text { Composite Analysis if Interacting Source }\end{array}$ & $\begin{array}{l}\text { See the responses to Conditions } 2 \\
\text { and } 3 .\end{array}$ \\
\hline
\end{tabular}




\begin{tabular}{|c|c|c|}
\hline Com. No. & Comment & Action \\
\hline & $\begin{array}{l}\text { Terms, the first, iteration of the composite } \\
\text { analysis will use only the information at hand; } \\
\text { no field samples will be collected for analysis. } \\
\text { However, there is a need for discussion } \\
\text { regarding the quality and level of certainty } \\
\text { associated with the source term data collected } \\
\text { and used in calculating the maximum dose. } \\
\text { As an example, Page 1 - 1, Section 1.0 } \\
\text { Summary and Conclusions, second paragraph } \\
\text { states: "Two former LLW disposal facilities, } \\
\text { the Mixed Waste Management Facility and } \\
\text { the Old Burial grounds, are the major sources } \\
\text { of these isotopes." Yet there is no discussion } \\
\text { regarding the uncertainty associated with each } \\
\text { source term developed and used in the } \\
\text { composite analysis. In fact, the following } \\
\text { statement is made in section } 3.3 .2 \text {, Data } \\
\text { Qualification: "Ranking according to degree } \\
\text { of certainty was not attempted because } \\
\text { information with which to make these } \\
\text { decisions is not complete." In order to } \\
\text { understand the sensitivity of the calculated } \\
\text { dose at the point of assessment with respect to } \\
\text { the contributing source terms, some indication } \\
\text { of the data quality and associated uncertainty } \\
\text { must be established. }\end{array}$ & \\
\hline 52 & $\begin{array}{l}\text { Page 3-3, Section 3.2.2, Step 2: Identify the } \\
\text { Decision, states: "The decision to be made in } \\
\text { this application of the DQO Process is } \\
\text { whether the resources available will provide a } \\
\text { reasonably representative residual inventory } \\
\text { upon which dose estimates for the Composite } \\
\text { Analysis can be based. Unacceptable data } \\
\text { quality or quantity will lead to unreliable } \\
\text { estimates of doses." } \\
\text { There is no discussion of the alternative } \\
\text { actions that may result from the identified } \\
\text { decision. In accordance with the EPA } \\
\text { guidance document for data quality } \\
\text { objectives, EPA QA/G-4, September } 1994, \\
\text { possible alternative actions that may result } \\
\text { from the decision question should be } \\
\text { identified. In other words, since the decision } \\
\text { is whether the resources available will provide } \\
\text { a reasonable residual inventory from which } \\
\text { dose estimates can be based, there should be } \\
\text { some discussion on actions to be taken if } \\
\text { available resources cannot provide for a }\end{array}$ & $\begin{array}{l}\text { Revision of the application of the } \\
\text { DQO Process to the CA will be } \\
\text { considered as the CA is } \\
\text { maintained. See the attached } \\
\text { maintenance plan. }\end{array}$ \\
\hline
\end{tabular}




\begin{tabular}{|c|c|c|}
\hline Com. No. & Comment & Action \\
\hline & reasonable inventory. & \\
\hline 53 & $\begin{array}{l}\text { Page 3-3, Section 3.2.2, Step 2: Identify Inputs } \\
\text { to the Decision, provides a discussion of the } \\
\text { various sources that were used to create a } \\
\text { residual radionuclide inventory for the } \\
\text { composite analysis. } \\
\text { However, there is no discussion regarding the } \\
\text { establishment of a level of acceptability for } \\
\text { the information being used for input into the } \\
\text { decision. The EPA guidance document for } \\
\text { data quality objectives, EPA QA/G-4, } \\
\text { September 1994, indicates that when } \\
\text { identifying inputs into the decision process, } \\
\text { action levels should be established which } \\
\text { define the basis for choosing between } \\
\text { alternative actions. It would appear that some } \\
\text { discussion is warranted in this section that } \\
\text { describes a level of acceptability for the } \\
\text { information where any information below the } \\
\text { established level would be considered } \\
\text { inadequate for providing a reasonable } \\
\text { inventory estimate or at a minimum be used in } \\
\text { assigning a level of certainty to the data. }\end{array}$ & $\begin{array}{l}\text { Revision of the application of the } \\
\text { DQO Process to the CA will be } \\
\text { considered as the CA is } \\
\text { maintained. See the attached } \\
\text { maintenance plan. }\end{array}$ \\
\hline$\overline{54}$ & $\begin{array}{l}\text { Page 3-6, Section } 3.2 .5, \text { Step 5: Develop a } \\
\text { Decision Rule, states "The decision rule } \\
\text { developed for this application of the DQO } \\
\text { Process can be stated as: "If the radionuclide } \\
\text { inventories identified for facilities and } \\
\text { specific locations in the domain of interest are } \\
\text { reviewed and deemed representative by } \\
\text { personnel knowledgeable about waste streams } \\
\text { and pertinent activities leading to residual } \\
\text { radionuclides, then the inventories will be } \\
\text { assumed to be appropriate for the Composite } \\
\text { Analysis. If the information is unavailable or } \\
\text { inadequate for a given facility, then the } \\
\text { inventory will be considered incomplete and } \\
\text { the composite analysis will not be considered } \\
\text { comprehensive." } \\
\text { A description of the level of acceptability for } \\
\text { the information used for the radionuclide } \\
\text { inventories should be included. Without a } \\
\text { description of the level of acceptability or } \\
\text { certainty as to what constitutes adequate } \\
\text { versus inadequate data, a conclusion as to the } \\
\text { sensitivity of the inventories to the estimated } \\
\text { dose cannot be drawn. It does not appear from }\end{array}$ & $\begin{array}{l}\text { Revision of the application of the } \\
\text { DQO Process to the CA will be } \\
\text { considered as the CA is } \\
\text { maintained. See the attached } \\
\text { maintenance plan. }\end{array}$ \\
\hline
\end{tabular}




\begin{tabular}{|c|c|c|}
\hline Com. No. & Comment & Action \\
\hline & $\begin{array}{l}\text { the document that any of the data reviewed } \\
\text { failed to meet the Decision Rule. Given the } \\
\text { stated lack of source term information, it is } \\
\text { surprising that none of the data reviewed } \\
\text { failed the Decision Rule. }\end{array}$ & \\
\hline 55 & $\begin{array}{l}\text { Page 3-7, Section 3.2.6, Step 6: Specify Limits } \\
\text { on Decision Errors, states: "There was no } \\
\text { exclusion of data during the initial evaluation. } \\
\text { Although a statistical analysis was not carried } \\
\text { out, and confidence limits were not } \\
\text { established, decision error was controlled } \\
\text { through careful development, review and } \\
\text { evaluation of data by qualified personnel." } \\
\text { More discussion regarding controlling } \\
\text { decision error is warranted. With the absence } \\
\text { of alternative actions, levels of acceptability, } \\
\text { and data confidence limits in the DQO } \\
\text { process, the reviewer is lead to conclude that } \\
\text { there was no mechanism for classifying any of } \\
\text { the data as unacceptable, and no further } \\
\text { evaluation of data will be conducted to } \\
\text { establish levels of certainty. }\end{array}$ & $\begin{array}{l}\text { Revision of the application of the } \\
\text { DQO Process to the CA will be } \\
\text { considered as the CA is } \\
\text { maintained. See the attached } \\
\text { maintenance plan. }\end{array}$ \\
\hline 56 & $\begin{array}{l}\text { Page 3-7, Section 3.2.6, Step 7: Optimize the } \\
\text { Design, states: "An alternative design would } \\
\text { include field collection of soils at given } \\
\text { facilities for radionuclide analyses. This } \\
\text { would provide actual analytical data. } \\
\text { However, the number of samples required in } \\
\text { addition to the time and cost for sampling and } \\
\text { analysis would be prohibitive for this initial } \\
\text { characterization." } \\
\text { This statement implies that additional } \\
\text { characterization activities will occur, but there } \\
\text { is no further discussion which describes what } \\
\text { additional activities beyond the initial } \\
\text { characterization are planned. This is } \\
\text { especially relevant for the former LLW burial } \\
\text { grounds that are major contributing source } \\
\text { terms, but no level of certainty has been } \\
\text { established. }\end{array}$ & $\begin{array}{l}\text { Revision of the application of the } \\
\text { DQO Process to the CA will be } \\
\text { considered as the CA is } \\
\text { maintained. See the attached } \\
\text { maintenance plan. }\end{array}$ \\
\hline 57 & $\begin{array}{l}\text { Page 3-11, Completeness, in the context of } \\
\text { data collection, completeness is used as a data } \\
\text { quality indicator which is defined as the } \\
\text { amount of collected data that is considered } \\
\text { valid compared to the amount of data planned } \\
\text { for. It appears from Chapter } 3 \text { that the data } \\
\text { quality for each of the data sources was }\end{array}$ & $\begin{array}{l}\text { Revision of the application of the } \\
\text { DQO Process to the CA will be } \\
\text { considered as the CA is } \\
\text { maintained. See the attached } \\
\text { maintenance plan. }\end{array}$ \\
\hline
\end{tabular}




\begin{tabular}{|c|c|c|}
\hline Com. No. & Comment & Action \\
\hline & $\begin{array}{l}\text { designated, but no assessment of the needed } \\
\text { data quality or quantity was made to } \\
\text { determine if the data quality received was. } \\
\text { adequate. }\end{array}$ & \\
\hline 58 & $\begin{array}{l}\text { Page 3-11, Section 3.3.2, Data Qualification, } \\
\text { this section states that the data sources were } \\
\text { assigned numerical codes which classify the } \\
\text { information according to type, but ranking } \\
\text { according to degree of certainty was not } \\
\text { attempted. However, the descriptions for each } \\
\text { of the numerical codes used for data } \\
\text { qualification on Page } 3-12 \text { all include } \\
\text { statements as to whether the quantities and } \\
\text { types of radionuclides are known or } \\
\text { estimated. These descriptions appear to infer } \\
\text { assigned levels of certainty based on the } \\
\text { source of the information. Furthermore, page } \\
3 \text { - } 18 \text { and Table } 3.3-3 \text { indicate that } 61 \% \text { of } \\
\text { the radionuclide inventory and associated } \\
\text { concentrations are considered known. } \\
\text { Clarification is needed as to how } 61 \% \text { of the } \\
\text { source term inventory can be assumed known } \\
\text { if sufficient information is not available to } \\
\text { ascertain any degree of certainty. }\end{array}$ & $\begin{array}{l}\text { Revision of the application of the } \\
\text { DQO Process to the CA will be } \\
\text { considered as the CA is } \\
\text { maintained. See the attached } \\
\text { maintenance plan. }\end{array}$ \\
\hline 59 & $\begin{array}{l}\text { Page 3-11, para. 3.3.2, although Data } \\
\text { Qualification was discussed, no conclusions } \\
\text { seem to have been drawn from this process, } \\
\text { no justification that the data quality is } \\
\text { acceptable and no recommendations for } \\
\text { necessary future actions were made. The CA } \\
\text { guide leads one to conclude that this DQO } \\
\text { process may recommend future data/sample } \\
\text { collection. }\end{array}$ & $\begin{array}{l}\text { Revision of the application of the } \\
\text { DQO Process to the CA will be } \\
\text { considered as the CA is } \\
\text { maintained. See the attached } \\
\text { maintenance plan. }\end{array}$ \\
\hline
\end{tabular}




\section{SUBSURFACE TRANSPORT}

\begin{tabular}{|c|c|c|}
\hline Com. No. & Comment & Action \\
\hline 60 & $\begin{array}{l}\text { Chapter } 3 \text {, throughout this chapter there is a } \\
\text { recognized need to identify and quantify } \\
\text { radionuclides. Where was the physical and } \\
\text { chemical form information captured? This } \\
\text { information is integral to the transport } \\
\text { mobility, release rate etc. }\end{array}$ & See the response to Condition 4 . \\
\hline 61 & $\begin{array}{l}\text { The methodology given for estimating the } \\
\text { release of radionuclides from the contributing } \\
\text { sources is not complete. While the PAs } \\
\text { contain a complete methodology, any } \\
\text { degradation of waste forms is not included in } \\
\text { the methodology for other sources. It is a } \\
\text { simplified leach rate model from the waste } \\
\text { form that does not include any consideration } \\
\text { of the physical and chemical characteristics of } \\
\text { the source materials and the site } \\
\text { characteristics. }\end{array}$ & $\begin{array}{l}\text { A simplified release model was } \\
\text { judged adequate for this first } \\
\text { iteration of the CA. }\end{array}$ \\
\hline 62 & $\begin{array}{l}\text { The modeling components selected for the } \\
\text { analysis are reasonable and make use of the } \\
\text { available data. The determination of the } \\
\text { conservative nature of the methodology is } \\
\text { difficult to assess. The scenarios considered } \\
\text { for the CA are not apparently conservative. }\end{array}$ & No response needed. \\
\hline 63 & $\begin{array}{l}\text { The assumption is made that spills are added } \\
\text { to the residual inventory of the tank group that } \\
\text { they belong to. This is non-conservative } \\
\text { because a source term that is already in the } \\
\text { ground is being modeled as though it were } \\
\text { encased in concrete with a } 300 \text { year tank } \\
\text { surrounding it }\end{array}$ & $\begin{array}{l}\text { In the response to Condition } 3 \text {, } \\
\text { the flux to the water table for each } \\
\text { spill was assessed separately from } \\
\text { the tank group. }\end{array}$ \\
\hline 64 & $\begin{array}{l}\text { The physical and chemical characteristics of } \\
\text { the source materials and site characteristics } \\
\text { are incorporated into the assignment of } \\
\text { distribution coefficients to the radionuclides } \\
\text { considered in detail in the CA. The CA } \\
\text { includes all of the data as diskettes in } \\
\text { Appendix B. The relationship betiveen the } \\
\text { input data files contained in the appendix and } \\
\text { the understanding of the physical and } \\
\text { chemical characteristics used in the CA is } \\
\text { unclear. The relationship between the data in } \\
\text { Appendix B and the release mechanisms is } \\
\text { not clear. }\end{array}$ & See the response to Condition 4 . \\
\hline 65 & $\begin{array}{l}\text { This requirement is addressed in the CA. As } \\
\text { noted in many of the comments in this } \\
\text { section, the justification or logic associated } \\
\text { with many of the assumptions is debatable. }\end{array}$ & See the response to Condition 4 . \\
\hline
\end{tabular}




\begin{tabular}{|c|c|c|}
\hline Com. No. & Comment & Action \\
\hline & $\begin{array}{l}\text { However, there do not appear to be any } \\
\text { significant changes to the conceptual model } \\
\text { used in the CA as compared to the PAs for. } \\
\text { either E-Area or Z-Area. }\end{array}$ & 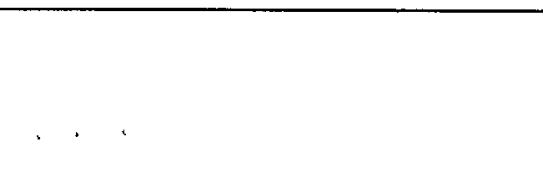 \\
\hline 66 & $\begin{array}{l}\text { Criterion } 6.3 .3 \text { is a similar requirement that is } \\
\text { associated with this comment. However, this } \\
\text { requirement speaks to the correctness of the } \\
\text { conceptual model. The conceptual model used } \\
\text { in the PA was developed for the close-in } \\
\text { analysis of E-Area and Z-Area, where the } \\
\text { point of compliance was about } 100 \text { meters } \\
\text { away from the disposal unit. For the CA the } \\
\text { conceptual model was extrapolated to include } \\
\text { all of the SRS. As a result, the conceptual } \\
\text { model does not include any additional } \\
\text { potential mechanisms related to the areal } \\
\text { extent of the confining units for the aquifers, } \\
\text { and the potential mixing between aquifer } \\
\text { layers away from the GSA. }\end{array}$ & $\begin{array}{l}\text { Per LFRG direction, the single } \\
\text { point of compliance for the CA is } \\
\text { the mouth of UTR. The only } \\
\text { sources outside the GSA that are } \\
\text { to be considered are those in the } \\
\text { A/M area. See the response to } \\
\text { Condition } 3 \text {. }\end{array}$ \\
\hline 67 & $\begin{array}{l}\text { Pg. 5-29, first paragraph - The first reason } \\
\text { given for neglecting mechanical dispersion is } \\
\text { that the time of assessment is } 1000 \text { years. } \\
\text { Hence, "this amount of time is sufficient for } \\
\text { arrival of the more concentrated portion of the } \\
\text { plume at the location of concern,". With some } \\
\text { nuclides of interest having high Kd values, it } \\
\text { is not apparent that this statement is accurate. } \\
\text { Justify this statement. }\end{array}$ & See the response to Condition 4 . \\
\hline 68 & $\begin{array}{l}\text { This requirement is not clearly satisfied in the } \\
\text { CA. As noted in other comments, the point of } \\
\text { assessment is not well defined in space or } \\
\text { time. Consequently, the conservative nature of } \\
\text { the methodology cannot be assessed. There } \\
\text { are indications from the omission of other } \\
\text { potentially significant sources of } \\
\text { contamination that the methodology used in } \\
\text { the CA is not conservative. } \\
\text { The transport of contamination is } \\
\text { accomplished by the application of the } \\
\text { PATHRAE, PORFLOW, and FACT models, } \\
\text { which have extensive data inputs. The inputs } \\
\text { to the models are provided in Appendix B, } \\
\text { without a guide to the contents. Consequently, } \\
\text { the files are mere compilations of numbers } \\
\text { without meaning. Therefore, making a } \\
\text { meaningful comment with respect to this } \\
\text { criterion is not possible. }\end{array}$ & $\begin{array}{l}\text { Per LFRG guidance, the CA point } \\
\text { of compliance is the mouth of } \\
\text { UTR. Only sources in the A/M- } \\
\text { Areas need be added to those in } \\
\text { the GSA. See the response to } \\
\text { Condition } 3 \text {. }\end{array}$ \\
\hline 69 & The known physical and chemical & As the CA is maintained, re- \\
\hline
\end{tabular}




\begin{tabular}{|l|l|l|}
\hline Com. No. & Comment & Action \\
\hline $\begin{array}{l}\text { characteristics of the radioactive materials } \\
\text { considered in the composite analysis are } \\
\text { discussed in the CA. The effect these } \\
\text { characteristics have on the source terms and } \\
\text { the transport of radionuclides is also discussed } \\
\text { in the CA. The correctness of the } \\
\text { characteristics is difficult to establish because } \\
\text { of the limited records available for old } \\
\text { disposals, and the limited understanding of the } \\
\text { behavior of the many different types of waste } \\
\text { forms at SRS. The significant uncertainties } \\
\text { associated with the physical and chemical } \\
\text { characteristics of the radioactive materials } \\
\text { considered in the CA should have been } \\
\text { considered in the sensitivity and uncertainty } \\
\text { analysis contained in the CA. }\end{array}$ & $\begin{array}{l}\text { andist } \\
\text { the characteristics of the waste } \\
\text { attached maintenance plan. }\end{array}$ \\
\hline
\end{tabular}




\section{HYDROLOGY}

\begin{tabular}{|c|c|c|}
\hline Com. No. & Comment & Action \\
\hline 70 & $\begin{array}{l}\text { The mathematical groundwater flow model is } \\
\text { based partly upon the assumption that there is } \\
\text { an upward hydraulic gradient across the } \\
\text { Crouch Branch confining unit. This gradient } \\
\text { is assumed to naturally protect the aquifers } \\
\text { beneath the Floridan aquifer system from } \\
\text { contamination (Composite Analysis, p. 2-23). } \\
\text { Using this assumption, the flow model was } \\
\text { constructed for the Floridan aquifers above } \\
\text { the Crouch Branch confining unit. } \\
\text { However, no reference is provided for the } \\
\text { above assumption. in the text or the } \\
\text { accompanying Figure } 2.3-5 \text {. Similarly, there } \\
\text { are no supporting data in the Saltstone and } \\
\text { E-Area Vaults Performance Assessment } \\
\text { (PAs), which also rely on this assumption. } \\
\text { Supporting data were provided during the } \\
\text { review and should be referenced in the CA. }\end{array}$ & See the response to Condition 4. \\
\hline 71 & $\begin{array}{l}\text { No volumetric mass balance was performed } \\
\text { on the amount of water flowing into the } \\
\text { model compared to the amount exiting the } \\
\text { model. This is a standard output for most } \\
\text { models and its absence from the discussion in } \\
\text { the CA, the two supporting PAs, and the } \\
\text { reference documentation from Flach and } \\
\text { Harris (1997) is troubling. Given } \\
\text { precipitation, infiltration (and hence runoff), } \\
\text { artificial recharge, discharge to the streams, } \\
\text { and leakance through the Crouch Branch } \\
\text { confining unit, a balance can be computed. It } \\
\text { is unlikely that the model will balance in its } \\
\text { present form because of the omission of flux } \\
\text { through the northern and eastern model } \\
\text { boundaries. }\end{array}$ & $\begin{array}{l}\text { Presentation of mass balance } \\
\text { information will be made in the } \\
\text { next revision. See the attached } \\
\text { maintenance plan. }\end{array}$ \\
\hline 72 & $\begin{array}{l}\text { The conservativeness of some model } \\
\text { assumptions has not been verified or } \\
\text { evaluated. One example is the assumption that } \\
\text { the Crouch Branch confining unit has an } \\
\text { upward gradient. Another example is the } \\
\text { assumption of no-flow boundaries to the } \\
\text { model. In both cases, if the assumptions are } \\
\text { wrong, additional aquifers could become } \\
\text { contaminated and travel times could be } \\
\text { significantly altered. It is not clear whether } \\
\text { these assumptions are conservative or not. }\end{array}$ & See the response to Condition 4 . \\
\hline 73 & The mathematical models utilized in the CA & No modeling exercise will ever \\
\hline
\end{tabular}




\begin{tabular}{|c|c|c|}
\hline Com. No. & Comment & Action \\
\hline & $\begin{array}{l}\text { utilized the available site data. The } \\
\text { PATHRAE and PORFLOW models were } \\
\text { used in the PAs for Z-Area and E-Area. } \\
\text { FACT was a model developed for the GSA } \\
\text { that was used for the CA. As discussed in the } \\
\text { site visit, the data to support the modeling of } \\
\text { the entire GSA is incomplete. This lack of } \\
\text { complete data to drive the three dimensional } \\
\text { models used for the CA introduces additional } \\
\text { uncertainty, which was not addressed in the } \\
\text { uncertainty analysis. }\end{array}$ & $\begin{array}{l}\text { have "complete" data. Data will } \\
\text { be reviewed annually and } \\
\text { incorporated in future revisions, } \\
\text { per CA maintenance. See the } \\
\text { attached maintenance plan. }\end{array}$ \\
\hline 74 & $\begin{array}{l}\text { The CA used essentially the same } \\
\text { assumptions and justifications as those used in } \\
\text { the PA's. The validity and adequacy of these } \\
\text { assumptions is addressed in other comments. }\end{array}$ & Comment noted. \\
\hline 75 & $\begin{array}{l}\text { PORFLOW and PATHRAE are documented } \\
\text { codes. LADTAP XL is referenced in the CA. } \\
\text { FACT is documented in the appendix to the } \\
\text { CA. All of these codes have been verified and } \\
\text { validated to a reasonable extent. }\end{array}$ & Comment noted. \\
\hline 76 & $\begin{array}{l}\text { From the PATHRAE input files, it can be } \\
\text { assumed that the precipitation runoff rate ( } 40 \\
\mathrm{~cm} / \mathrm{yr} \text { ) plus the watershed infiltration rate }(40 \\
\mathrm{cm} / \mathrm{yr} \text { ) should equal the total precipitation. } \\
\text { The total precipitation given in } 124 \mathrm{~cm} / \mathrm{yr} \\
\text { (pg.2-13). The remaining balance should be } \\
\text { accounted for. }\end{array}$ & $\begin{array}{l}\text { The balance is due to evapo- } \\
\text { transpiration }\end{array}$ \\
\hline 77 & $\begin{array}{l}\text { The assumptions incorporated into the } \\
\text { mathematical model used for the performance } \\
\text { assessment were used in the composite } \\
\text { analysis as well. These assumptions were } \\
\text { identified in the PAs and CAs. Some } \\
\text { assumptions are not well identified or } \\
\text { justified. The other comments identify some } \\
\text { of these examples. Additional examples are } \\
\text { related to the site hydrology and are covered } \\
\text { in Criterion 6.3.6. }\end{array}$ & See the response to Condition 4. \\
\hline 78 & $\begin{array}{l}\text { Calibration of the flow model indicates } \\
\text { problems with the conceptual model and } \\
\text { numerical model boundary Conditions. The } \\
\text { model results as summarized in Figure 5.1-18 } \\
\text { and Figure 5.1-19 show the effects of a large } \\
\text { groundwater mound in H Area. This mound is } \\
\text { not discussed in the CA but is thoroughly } \\
\text { described in Flach and Harris (1997). } \\
\text { Calibration of the model to incorporate the } \\
\text { mound required significant changes in } \\
\text { conductivity and in recharge. This included } \\
\text { changes to the vertical and horizontal }\end{array}$ & See the response to Condition 2 . \\
\hline
\end{tabular}




\begin{tabular}{|c|c|c|}
\hline Com. No. & Comment & Action \\
\hline & $\begin{array}{l}\text { conductivity in the upper and lower aquifers } \\
\text { and the tan clay as shown in Flach and Harris, } \\
\text { Figures } 26,27 \text {, and } 28 \text { and Table } 5 \text {. Increases } \\
\text { to recharge are, on average, the equivalent of } \\
\text { the annual natural recharge and range up to } \\
\text { twice the natural recharge (Flach and Harris, } \\
\text { Figure } 22 \text { ). From Figure } 22 \text { the artificial } \\
\text { recharge can be estimated at } 1.6 \mathrm{Mm}^{3} \text { per year } \\
\text { or } 1300 \text { acre-feet/year. } \\
\text { The changes in conductivity are not supported } \\
\text { by specific field data but are within the range } \\
\text { of variability common in field permeability } \\
\text { measurements. The increase in artificial } \\
\text { recharge is poorly supported by anecdotal } \\
\text { evidence of leakage in water and sewer } \\
\text { systems (Flach and Harris, } 1997 \text {, page } 20 \text { ). If } \\
\text { leakages of over a million cubic meters per } \\
\text { year are present, it should be possible to } \\
\text { provide an accounting of known water } \\
\text { production from water supply wells and } \\
\text { discharge to water disposal systems to verify } \\
\text { the model assumptions. The lack of such data } \\
\text { calls the interpretation into question. } \\
\text { An alternative to the model modifications of } \\
\text { conductivity and artificial recharge is to } \\
\text { account for the flux entering the eastern side } \\
\text { of the model (see boundary Condition } \\
\text { comment above). Treating this flux boundary } \\
\text { as a no-flow boundary causes flow directions } \\
\text { to track north along the eastern model } \\
\text { boundary (see Figure } 5.1-18 \text { ) rather than } \\
\text { westward to supply the groundwater mound. } \\
\text { In addition, the use of phantom data points, or } \\
\text { control data, in Figure } 5.1-13 \text { may be masking } \\
\text { a true gradient that is more indicative of } \\
\text { westward flow across the model boundary. }\end{array}$ & \\
\hline 79 & $\begin{array}{l}\text { The mathematical models used in the CA } \\
\text { for analyzing transport are appropriate and } \\
\text { provide calculated results which are } \\
\text { representative of the results calculated in } \\
\text { the PA }\end{array}$ & Comment noted. \\
\hline 80 & $\begin{array}{l}\text { This requirement is not clearly achieved in the } \\
\text { CA. Assumptions have been used in the CA to } \\
\text { formulate input data, but the justification and } \\
\text { defensibility of the assumptions is not clearly } \\
\text { presented. The relationship between the input } \\
\text { data and the source of the input data by either }\end{array}$ & See the response to Condition 4 . \\
\hline
\end{tabular}




\begin{tabular}{|c|c|c|}
\hline Com. No. & Comment & Action \\
\hline & $\begin{array}{l}\text { field data, laboratory data, reference, or } \\
\text { assumption is not presented in the CA. Input } \\
\text { data such as the invariant infiltration rates and } \\
\text { the distribution coefficients are not justified. }\end{array}$ & \\
\hline 81 & $\begin{array}{l}\text { The assumption of isolation of lower aquifers } \\
\text { is at odds with site physical data. The CA } \\
\text { states that the confining nature of the Crouch } \\
\text { Branch confining unit in the GSA and the } \\
\text { head-reversal phenomenon naturally protect } \\
\text { the aquifers beneath the Floridan (sic) aquifer } \\
\text { system from contamination? (CA, page 2-23). } \\
\text { However, the CA Figure } 2.3-5 \text { and supporting } \\
\text { data provided during the site review (Aadland } \\
\text { and others, 1995, and Christensen and } \\
\text { Gordon, 1983) show that the gradient from } \\
\text { the Crouch Branch aquifer to the Gordon } \\
\text { aquifer is thought to be downward } \\
\text { immediately to the southeast of S and H } \\
\text { Areas. The downward gradient can be seen by } \\
\text { inspection of Figures } 14 \text { and } 10 \text { in Flach and } \\
\text { Harris, } 1997 \text {. This assumption is incorporated } \\
\text { into the numerical model by virtue of the } \\
\text { lower model boundary definition as a general } \\
\text { head boundary with flux dependent upon head } \\
\text { in the underlying Crouch Branch aquifer and } \\
\text { overlying Gordon aquifer (Flach and Harris, } \\
\text { 1997, page } 11 \text { ). } \\
\text { The downward gradient present in the } \\
\text { southeast comer of the model is a violation of } \\
\text { the conceptual model assumption of no } \\
\text { downward flow from the Gordon aquifer to } \\
\text { the Upper Three Runs aquifer. Owing to the } \\
\text { location of the sources in the General } \\
\text { Separations Area and the probable flux into } \\
\text { the model domain from the east, it is unlikely } \\
\text { that contamination could reach the underlying } \\
\text { Crouch Branch aquifer via this route. } \\
\text { However, the protection of the Gordon aquifer } \\
\text { is more complex than depicted in the model } \\
\text { and is dependent upon accepting the heads, } \\
\text { conductivities, and leakances as characterized } \\
\text { in the model. }\end{array}$ & See the response to Condition 2 . \\
\hline 82 & $\begin{array}{l}\text { Three wells in } \mathrm{Z} \text { and S Areas are at odds with } \\
\text { the conceptual model. Wells ZBG } 1 \mathrm{~A}, \mathrm{SCA} \\
3 \mathrm{~A} \text {, and SCA } 4 \mathrm{~A} \text { (Flach and Harris, 1997, } \\
\text { Appendix C, pages } 113 \text { and 114) are } \\
\text { completed } 30 \text { to } 40 \text { feet deeper than nearby } \\
\text { companion wells in well clusters. In all three }\end{array}$ & $\begin{array}{l}\text { This will be addressed as the CA } \\
\text { is maintained. See the attached } \\
\text { maintenance plan. }\end{array}$ \\
\hline
\end{tabular}




\begin{tabular}{|c|c|c|}
\hline Com. No. & Comment & Action \\
\hline & $\begin{array}{l}\text { cases, the deeper well has a higher head than } \\
\text { the shallower well, with the increase in head } \\
\text { approximately equal to the difference in } \\
\text { depth. This indicates a substantial upward } \\
\text { hydraulic gradient in the water table aquifer of } \\
\text { the } Z \text { and S Areas of approximately } \\
\text { one-to-one. This phenomenon is not discussed } \\
\text { nor accounted for in the conceptual and } \\
\text { numerical models, even though it is at odds } \\
\text { with the conceptual model of downward } \\
\text { gradient in the Upper Three Runs aquifer. The } \\
\text { impact on flow directions is hard to predict } \\
\text { (with respect to conservatism) but the } \\
\text { uncertainty associated with the model is } \\
\text { increased. }\end{array}$ & \\
\hline$\overline{83}$ & $\begin{array}{l}\text { The flow model contains assumptions about } \\
\text { boundary conditions which are not correct. } \\
\text { a) The Gordon aquifer at Upper Three Runs } \\
\text { Creek is defined as a no-flow boundary } \\
\text { (Figure 5.1-1), when it appears that the } \\
\text { Gordon aquifer continues to the northwest } \\
\text { as part of the Steed Pond aquifer (see } \\
\text { Aadland and others, 1995, Plate 3). The } \\
\text { Gordon aquifer ceases only by definition } \\
\text { because of the updip truncation of the } \\
\text { Gordon confining unit. No data are } \\
\text { presented on the hydraulic and hydrologic } \\
\text { characteristics of the northwest } \\
\text { continuation of the Gordon aquifer } \\
\text { beyond Upper Three Runs Creek, so it is } \\
\text { difficult to determine if this is a } \\
\text { significant point. The model assumption } \\
\text { is contradicted by the following statement } \\
\text { from the CA: The Gordon aquifer is } \\
\text { recharged both by precipitation within the } \\
\text { GSA and by lateral flow from outside the } \\
\text { GSA (page 6-6). } \\
\text { The Upper Three Runs aquifer at } \\
\text { Fourmile Branch is defined as a no-flow } \\
\text { boundary (Figure 5. 1-1) when it appears } \\
\text { that the lower unit, beneath the tan clay, } \\
\text { continues to the southeast (see Aadland } \\
\text { and others, 1995, Plate 3). Since leakage } \\
\text { through the tan clay and discharge of the } \\
\text { lower unit to Upper Three Runs aquifer } \\
\text { are included in the model, this can be } \\
\text { expected to be a flux boundary of } \\
\text { unknown magnitude. }\end{array}$ & See the response to Condition 4 . \\
\hline
\end{tabular}




\begin{tabular}{|c|c|c|}
\hline Com. No. & Comment & Action \\
\hline & $\begin{array}{l}\text { c) The Upper Three Runs aquifer at the } \\
\text { eastern boundary of the model between } \\
\text { McQueen Branch and Fourmile Run is } \\
\text { defined as a no-flow boundary (figure } \\
5.1-1 \text { ). The measured head map of Figure } \\
5.1-13 \text { shows that a westward flux into the } \\
\text { model domain along this boundary is } \\
\text { probable. Note also that the head map } \\
\text { uses control data (invented data) to } \\
\text { modify head contour lines in this area, } \\
\text { potentially masking a larger gradient than } \\
\text { shown. }\end{array}$ & \\
\hline 84 & $\begin{array}{l}\text { The measured head map of Figure } 5.1-13 \\
\text { contains a sharp groundwater mound in Z } \\
\text { Area (in the northeast part of the model } \\
\text { domain) related to well ZBG 1A. The mound } \\
\text { is not simulated by the model (see head map } \\
\text { of Figure 5. 1 -11). The figures are from Flach } \\
\text { and Harris (1997), Figures } 11 \text { and } 36 \text {. Neither } \\
\text { the CA nor Flach and Harris explain that the } \\
\text { mound is the result of one data point, well } \\
\text { ZBG } 1 \text { A, which was omitted from the model } \\
\text { as an outlier after completion of the measured } \\
\text { head map (Flach and Harris, Appendix E, } \\
\text { page 137). } \\
\text { In contrast, two other wells with anomalous } \\
\text { head data in nearby S Area were omitted from } \\
\text { the measured head map (wells SCA 3A and } \\
\text { SC.A 4A) The head data from all three wells } \\
\text { should be treated the same. }\end{array}$ & See the response to Condition 4 . \\
\hline 85 & $\begin{array}{l}\text { The CA does not provide intermediate } \\
\text { calculations and results to demonstrate the CA } \\
\text { calculations are repiesentative of the site for } \\
\text { similar situations. Comparisons between the } \\
\text { PA results for E-Area and Z-Area, and the CA } \\
\text { results are not provided. Concluding the PAs } \\
\text { and CA are similar on the basis of the } \\
\text { calculations has not been demonstrated. }\end{array}$ & $\begin{array}{l}\text { In the next revision of the } \mathrm{CA} \text {, } \\
\text { consideration will be given to } \\
\text { providing intermediate } \\
\text { calculations and results. }\end{array}$ \\
\hline 86 & $\begin{array}{l}\text { The conceptual model used in the CA is } \\
\text { consistent with the conceptual model in the } \\
\text { PA. However, the additional components of a } \\
\text { conceptual model for the SRS are not clearly } \\
\text { introduced into the CA to ensure that regional } \\
\text { subsurface phenomena and surface and } \\
\text { groundwater interactions are properly } \\
\text { considered in the CA. The material presented }\end{array}$ & $\begin{array}{l}\text { Flux to the water table results are } \\
\text { given in the CA to satisfy the } \\
\text { intermediate results criteria. The } \\
\text { results in Table } 4.4-5 \text { for the } \\
\text { facilities labeled ILT, LAW and } \\
\text { SLIT are for units in the EA PA. } \\
\text { Entries under SALT are for the } \\
\text { Saltstone facility. These data can }\end{array}$ \\
\hline
\end{tabular}




\begin{tabular}{|c|c|c|}
\hline Com. No. & Comment & Action \\
\hline & $\begin{array}{l}\text { in the CA does not clearly address how the } \\
\text { regional aquifer characteristics are included in } \\
\text { the conceptual model. }\end{array}$ & be used to compare results. \\
\hline 87 & $\begin{array}{l}\text { The reliance on natural hydrologic barriers as } \\
\text { effective mechanisms for preventing or } \\
\text { controlling contaminant migration, are not } \\
\text { adequately justified in this document, from a } \\
\text { technical perspective. Additional data, and } \\
\text { where appropriate, additional studies, must be } \\
\text { provided to substantiate their effectiveness, or } \\
\text { additional model uncertainty must be } \\
\text { incorporated. }\end{array}$ & See the response to Condition 4. \\
\hline 88 & $\begin{array}{l}\text { This requirement speaks to the rigor included } \\
\text { in the CA. While many of the assumptions in } \\
\text { the CA related to the radionuclides have been } \\
\text { examined, the examination has not been } \\
\text { rigorous, as noted in previous comments. The } \\
\text { source term evaluation similarly has questions } \\
\text { concerning the rigor of analysis, as noted in } \\
\text { earlier comments. The transport of } \\
\text { radionuclides largely relies on the models } \\
\text { used in the PAs for the two facilities that were } \\
\text { extrapolated to the entire GSA, and the data } \\
\text { driven FACT code, which has recently been } \\
\text { developed and to some extent verified and } \\
\text { validated. The lack of intermediate results, } \\
\text { which are referenced to field or laboratory } \\
\text { data, is a shortcoming in the CA that leaves } \\
\text { many of the questions concerning the } \\
\text { transport of radionuclides unanswered. This } \\
\text { leads to uncertainties in results which have } \\
\text { not been evaluated in the CA. }\end{array}$ & $\begin{array}{l}\text { See the response to Conditions } 3 \\
\text { and } 4 .\end{array}$ \\
\hline 89 & $\begin{array}{l}\text { The assumption that anthropogenic changes } \\
\text { will not alter the model results needs to be } \\
\text { justified. To demonstrate that the CA is } \\
\text { technically adequate, there must be more } \\
\text { information provided on the assumptions that } \\
\text { the hydrologic conditions that cause the } \\
\text { natural hydrologic barriers will not change } \\
\text { significantly over the time period of the } \\
\text { analysis. As it stands, the only assurance that } \\
\text { can be made is that institutional controls will } \\
\text { prevent any on-site activity from disrupting } \\
\text { flow conditions that would significantly } \\
\text { impact the natural hydrologic barriers, and } \\
\text { that off-site activities, such as large scale } \\
\text { irrigation, are not likely. Since, therefore, no } \\
\text { reasonable assurance can be given to justify } \\
\text { the assumptions regarding flow conditions, }\end{array}$ & See the response to Condition 4 . \\
\hline
\end{tabular}




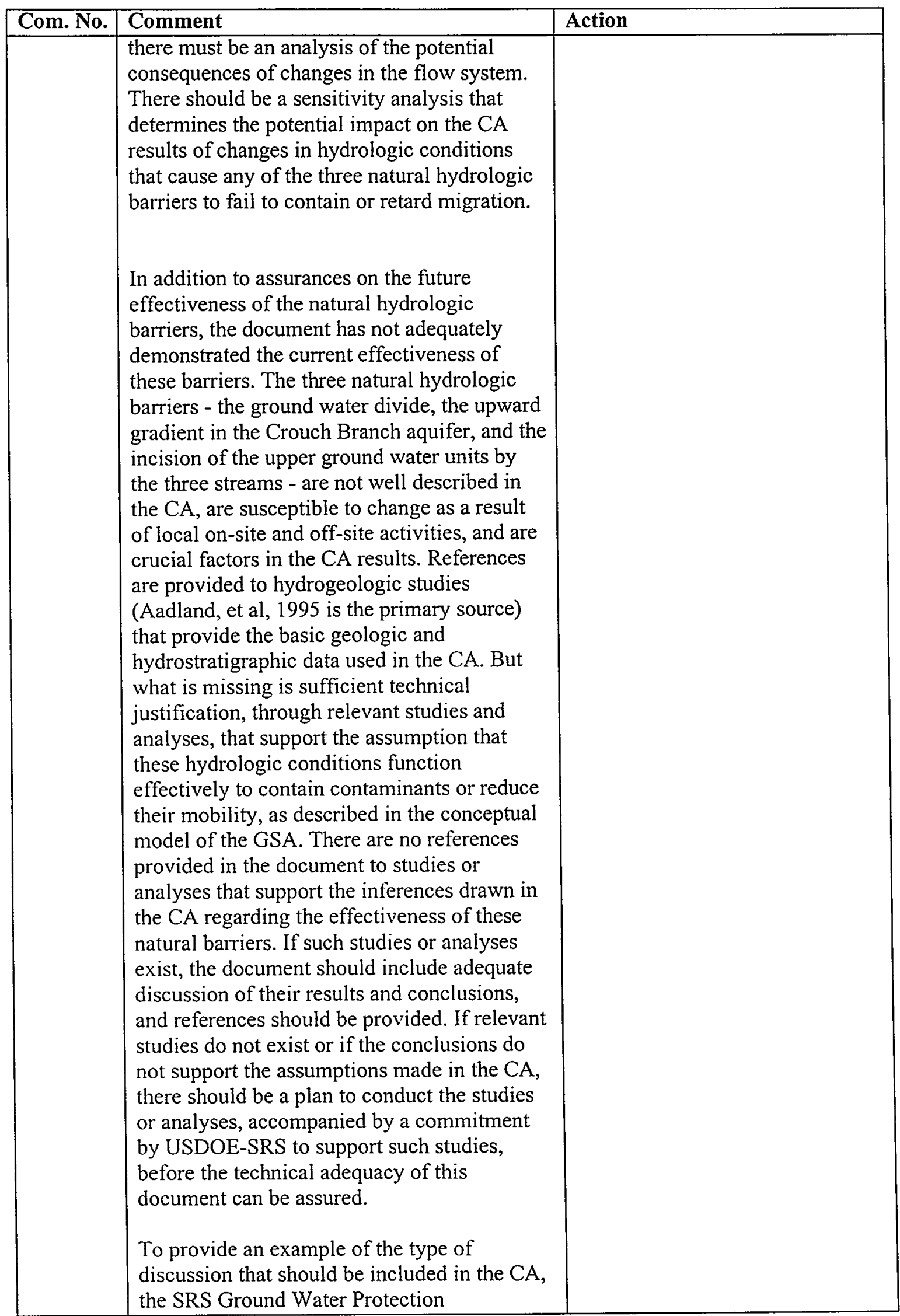




\begin{tabular}{|l|l|l|}
\hline Com. No. & Comment & Action \\
\hline & $\begin{array}{l}\text { Management Program (GWPMP) document } \\
\text { (WSRC-TR-96-0193), dated August 1996, } \\
\text { provides a very brief discussion of one of the } \\
\text { natural hydrologic barriers - the upward } \\
\text { gradient. There is a discussion (Section 2.6) of } \\
\text { the maintenance of natural head differences } \\
\text { across the site, due to recognition of the value } \\
\text { of the upward gradient in preventing } \\
\text { downward migration of contaminants. There } \\
\text { is a brief discussion of a long-standing } \\
\text { site-wide policy of avoiding installation of } \\
\text { high capacity production wells in areas where } \\
\text { this natural upward gradient may be disturbed } \\
\text { by pumping. The GWPMP indicates that this } \\
\text { policy (put into effect in the 1980's) is still in } \\
\text { effect, but there is no reference provided, nor } \\
\text { is there any further detailed discussion of } \\
\text { what actions this policy actually addresses. } \\
\text { This entire issue is not discussed in the CA at } \\
\text { all. There are no references to any section of } \\
\text { the GWPMP. The CA should, at a minimum, } \\
\text { investigate the specific provisions of this } \\
\text { policy, discuss how well it has been } \\
\text { implemented since its inception, and relate } \\
\text { what is known about the process of } \\
\text { maintenance of the upward gradient to the } \\
\text { specific assumptions included in the } \\
\text { conceptual model of the GSA that supports } \\
\text { the analysis in the CA. }\end{array}$ & \\
\hline
\end{tabular}




\section{INFORMATION MISSING FROM THE CA - COMPLETENESS CONCERNS}

\begin{tabular}{|c|c|c|}
\hline Com. No. & Comment & Action \\
\hline 90 & $\begin{array}{l}\text { The CA document dated September } 1997 \text { is } \\
\text { not complete. The CA Review Team cannot } \\
\text { reach a decision that ensures continued } \\
\text { compliance with USDOE Order requirements } \\
\text { at the two SRS disposal sites. In addition to } \\
\text { further analyses and data collection described } \\
\text { elsewhere in these comments, the analyses } \\
\text { and data that are contained in this document } \\
\text { are not complete. There are many statements } \\
\text { that need to be better supported by references } \\
\text { or by more complete analyses and } \\
\text { explanations that clearly describe the analysts' } \\
\text { logic. }\end{array}$ & $\begin{array}{l}\text { No action required. The LFRG } \\
\text { concluded that the CA provided } \\
\text { sufficient information to support } \\
\text { management decision for } \\
\text { continued compliance with } \\
\text { USDOE Order requirements at } \\
\text { the two SRS disposal sites. }\end{array}$ \\
\hline 91 & $\begin{array}{l}\text { The document that the review team was asked } \\
\text { to review is not complete. It basically presents } \\
\text { statements of conclusion regarding the } \\
\text { potential impact of the disposal facilities on } \\
\text { the general public and on the environment, } \\
\text { and statements that describe hydrologic } \\
\text { conditions without adequate explanation, with } \\
\text { few, or frequently no, reference to any } \\
\text { detailed studies or other source documents, } \\
\text { and with few new studies or analyses } \\
\text { conducted to support the CA. The document, } \\
\text { issued September } 1997 \text {, contains some } \\
\text { statements and conclusions that are } \\
\text { unsupported (but not necessarily } \\
\text { unsupportable) from a technical perspective. } \\
\text { The document is incomplete because it does } \\
\text { not enable the reviewer to understand the } \\
\text { analyst's logic, or to reveal how the analysts } \\
\text { used their data, their knowledge of the site, } \\
\text { and their analytical tools to determine their } \\
\text { results and to draw their conclusions. } \\
\text { As a reviewer, I am left with the task of trying } \\
\text { to piece together all of the technical work that } \\
\text { was done on the CA to fully understand how } \\
\text { the final results were derived. It became } \\
\text { obvious to me during the initial site visit, } \\
\text { when listening to presentations from various } \\
\text { WSRC staff who had prepared the CA, that } \\
\text { the technical work had been performed. The } \\
\text { review team had numerous questions } \\
\text { regarding the analyses described in the } \\
\text { document, and most of these questions were } \\
\text { answered satisfactorily by WSRC staff. It } \\
\text { appears, though, that the information }\end{array}$ & $\begin{array}{l}\text { No action required. The LFRG } \\
\text { concluded that the CA provided } \\
\text { sufficient information to support } \\
\text { the management decision for } \\
\text { continued operation of the SRS } \\
\text { LLW disposal facilities. }\end{array}$ \\
\hline
\end{tabular}




\begin{tabular}{|c|c|c|}
\hline Com. No. & Comment & Action \\
\hline & $\begin{array}{l}\text { presented was not documented. The document } \\
\text { did not contain a complete and understandable } \\
\text { description of what that work was, nor a } \\
\text { mapping of the analysts' thought processes to } \\
\text { allow the reviewer to trace the path from the } \\
\text { basic data to the conclusions of the CA. }\end{array}$ & \\
\hline 92 & $\begin{array}{l}\text { Page 2-35, first sentence of the fifth paragraph } \\
\text { states: "Concentrations of radioactive material } \\
\text { at the mouths of the UTR and FMB will } \\
\text { potentially include contributions from sources } \\
\text { outside the GSA." However, the third } \\
\text { sentence of this same paragraph states: "The } \\
\text { composite analysis, however, has only } \\
\text { considered the sources within the GSA } \\
\text { because it is those sources that could } \\
\text { influence decisions regarding operations of } \\
\text { the LLW disposal facilities." } \\
\text { The April } 30,1996 \text { Guidance for a Composite } \\
\text { Analysis of Interacting Source Terms and the } \\
\text { November } 1,1996 \text { Interim Review Process } \\
\text { and Criteria for Composite Analysis both } \\
\text { indicate that the purpose of a composite } \\
\text { analysis is to provide an analysis of the } \\
\text { cumulative impacts of sources from LLW } \\
\text { disposal facilities and all other sources that } \\
\text { may interact with the LLW disposal facilities } \\
\text { and contribute to the dose to a hypothetical } \\
\text { future member of the public. } \\
\text { It would appear that all source terms having } \\
\text { the potential to interact at or before the point } \\
\text { of assessment, must be considered and } \\
\text { included in the composite analysis. This } \\
\text { would be necessary to provide for a } \\
\text { reasonably conservative estimate of the } \\
\text { cumulative impacts of those source terms and } \\
\text { their affects to the dose to future members of } \\
\text { the public. }\end{array}$ & See the response to Condition 1 . \\
\hline 93 & $\begin{array}{l}\text { The flow and transport models, as well as the } \\
\text { conceptual model, of the ground water system } \\
\text { at the GSA and the interrelationship of ground } \\
\text { water and surface water needs further } \\
\text { validation. Performing a water balance } \\
\text { analysis of the GSA is one aspect of the } \\
\text { needed validation. Designing and } \\
\text { implementing an on-going monitoring } \\
\text { strategy that will also function as a } \\
\text { surveillance monitoring system is also needed }\end{array}$ & $\begin{array}{l}\text { Comment noted. This will be } \\
\text { addressed as } R \& D \text { during the } \\
\text { course of CA maintenance. See } \\
\text { the attached maintenance plan. }\end{array}$ \\
\hline
\end{tabular}




\begin{tabular}{|c|c|c|}
\hline Com. No. & Comment & Action \\
\hline & for model validation. & \\
\hline 94 & $\begin{array}{l}\text { Sensitivity analysis (Section } 6.0 \text { ) is } \\
\text { inadequate and needs to be rewritten. At a } \\
\text { minimum, this section needs to be rewritten to } \\
\text { account for the additional data provided by } \\
\text { WSRC in the } 4 / 21 / 98 \text { memo from Bill Noll to } \\
\text { Jeff Perry, and needs to consider the analysis } \\
\text { of the effect of on-going remediation on the } \\
\text { flow system, provided in "Impact of F-and } \\
\text { H-Area Pump-Treat-Reinject Remediation } \\
\text { Systems on the Old Radioactive Waste Burial } \\
\text { Ground" (SRT-EST-98-154). Also, estimates } \\
\text { of greatest uncertainty are needed to. provide } \\
\text { direction and priorities for a CA maintenance } \\
\text { program. }\end{array}$ & See the response to Condition 2 . \\
\hline 95 & $\begin{array}{l}\text { The Savannah River CA, Section 6.3, Page } \\
\text { 6-3; The first paragraph states "Plans for } \\
\text { future use of the SRS (Appendix A) propose } \\
\text { that release of the site to the general public for } \\
\text { unrestricted use will not occur over the time } \\
\text { period of this analysis." } \\
\text { Appendix A; "Savannah River Site Future } \\
\text { Use Project Report," is cited as the decision } \\
\text { basis for future activities at the Savannah } \\
\text { River Site. This project report does not } \\
\text { reference or contain commitments made by } \\
\text { the Department of Energy to its stakeholders } \\
\text { regarding the future of the site. Composite } \\
\text { analyses are conducted to demonstrate that } \\
\text { management of all radioactive source terms; } \\
\text { (past, present, and future) will not reasonably } \\
\text { result in exceeding the dose limits set forth in } \\
\text { USDOE Order } 5400.5 \text {. Therefore, it would be } \\
\text { prudent for the composite analysis to address } \\
\text { all pertinent RODs, and other agreements } \\
\text { made to the SRS stakeholders by the } \\
\text { Department of Energy. No uncertainty } \\
\text { analysis has been performed. }\end{array}$ & $\begin{array}{l}\text { The SRS Future Use Plan has } \\
\text { been transmitted to USDOE-HQ. } \\
\text { This plan will be used as } \\
\text { Appendix A in future CA } \\
\text { revisions. }\end{array}$ \\
\hline 96 & $\begin{array}{l}\text { It is apparent that all of the potential } \\
\text { interacting source terms have not been } \\
\text { included in the analysis. The supplemental } \\
\text { information provides a scoping analysis of the } \\
\text { A and M-Areas, SRTC, and the SRL Seepage } \\
\text { basins and their impacts on the UTR. It is not } \\
\text { apparent from the document that B-Area, } \\
\text { C-Area, D-Area, N-Area, or R-Area will not } \\
\text { impact the analysis. The CA needs to include } \\
\text { a comprehensive look at the SRS and specify }\end{array}$ & $\begin{array}{l}\text { See the responses to Conditions } 1 \\
\text { and } 3 .\end{array}$ \\
\hline
\end{tabular}




\begin{tabular}{|c|c|c|}
\hline Com. No. & Comment & Action \\
\hline & $\begin{array}{l}\text { what will and what will not impact the LLW } \\
\text { disposal facility and provide justification for } \\
\text { these exclusions. }\end{array}$ & \\
\hline 97 & $\begin{array}{l}\text { The Industrial Wastewater Closure Plan for F- } \\
\text { and H-Area High-Level Waste Tank Systems } \\
\text { needs to be incorporated into the CA. The } \\
\text { stated CA requirement that most of the tanks } \\
\text { be emptied with only } 100 \text { gallons of residual } \\
\text { material is a requirement that must be } \\
\text { communicated with the HLW Tank Closure } \\
\text { project. }\end{array}$ & $\begin{array}{l}\text { HLW Tank personnel are familiar } \\
\text { with CA program. Updates in } \\
\text { tank closure program will be } \\
\text { reflected in CA maintenance } \\
\text { activities. See the attached } \\
\text { maintenance plan. }\end{array}$ \\
\hline 98 & $\begin{array}{l}\text { It is imperative that a good map of the SRS } \\
\text { and GSA with all SRS facilities located on it } \\
\text { be provided in the CA. It is difficult to } \\
\text { understand the relative locations of the } \\
\text { sources and LLW facilities with descriptive } \\
\text { information only. }\end{array}$ & $\begin{array}{l}\text { Comment noted and will be } \\
\text { implemented in next revision of } \\
\text { CA. }\end{array}$ \\
\hline 99 & $\begin{array}{l}\text { There is no discussion of the infiltration rates } \\
\text { used in the analysis. }\end{array}$ & $\begin{array}{l}\text { A table giving the infiltration } \\
\text { rates used will be provided in the } \\
\text { next CA revision. }\end{array}$ \\
\hline 100 & $\begin{array}{l}\text { There is no discussion of the corrosion rates } \\
\text { used for the various waste forms. While leach } \\
\text { rates are given for the concrete in the } \\
\text { supplemental information provided, it is } \\
\text { unknown whether the concrete is being } \\
\text { considered to last for the entire } 1000 \text { year } \\
\text { time of compliance. While the EAV and the } \\
\text { Saltstone PAs provide justification for this } \\
\text { assumption, the other concrete waste forms } \\
\text { (i.e. the HLW tanks) have not been shown to } \\
\text { meet this criteria. No corrosion data is given } \\
\text { nor are the assumptions stated for the } \\
\text { corrosion rates for the NR activated metals. } \\
\text { Given the lack of information on this topic, } \\
\text { the team is unable to assess whether the } \\
\text { assumptions used are conservative or } \\
\text { reasonable. }\end{array}$ & See the response to Condition 4 . \\
\hline 101 & $\begin{array}{l}\text { The possible CERCLA and RCRA actions are } \\
\text { included in the CA. There is no evidence } \\
\text { provided that the representation of the } \\
\text { possible future CERCLA actions is } \\
\text { conservative, justified or supported by } \\
\text { referenced documentation. Some of the } \\
\text { representations of CERCLA actions presumed } \\
\text { the outcome of the CERCLA process while } \\
\text { other future CERCLA actions were not } \\
\text { discussed. The site visit underscored the } \\
\text { changing climate of RCRA and CERCLA } \\
\text { actions at SRS, including the concept that }\end{array}$ & $\begin{array}{l}\text { As CERCLA and RCRA actions } \\
\text { are planned and completed they } \\
\text { will be more accurately } \\
\text { represented in CA revisions. See } \\
\text { the attached CA maintenance } \\
\text { plan. }\end{array}$ \\
\hline
\end{tabular}




\begin{tabular}{|c|c|c|}
\hline Com. No. & Comment & Action \\
\hline & $\begin{array}{l}\text { RCRA actions being performed now will need } \\
\text { to be addressed by CERCLA at some future } \\
\text { point in time. }\end{array}$ & \\
\hline 102 & $\begin{array}{l}\text { In section } 4.1 .2 \text { for building } 235-\mathrm{F} \text {, it is stated } \\
\text { that the residual radionuclide inventory was } \\
\text { provided by Mr. Ray Lux. The reference } \\
\text { document for this information is simply an } \\
\text { E-mail message giving the source term. This } \\
\text { does not adequately specify the source of the } \\
\text { characterization information. It appears that } \\
\text { the source term information came from the } \\
\text { SAR for building } 235-\mathrm{F} \text {. It is important (as a } \\
\text { minimum in the reference documents) to state } \\
\text { where the characterization information was } \\
\text { obtained, to provide an indication of the } \\
\text { accuracy of the information, and what } \\
\text { assumptions were used. }\end{array}$ & See the response to Condition 4 . \\
\hline 103 & $\begin{array}{l}\text { The effects of the ER cap (infiltration rates, } \\
\text { impact on the ground water model) on the Old } \\
\text { Burial Grounds is not given in the CA. While } \\
\text { most of this information has been provided in } \\
\text { the supplemental information provided, it } \\
\text { needs to be incorporated into the CA. }\end{array}$ & See the response to Condition 2 . \\
\hline 104 & $\begin{array}{l}\text { Incomplete Explanation of the } \\
\text { Interrelationship of Ground Water Units and } \\
\text { the Three Streams at the GSA - It appears that } \\
\text { the full explanation of the relationship } \\
\text { between the Upper Three Runs aquifer and } \\
\text { the three surface water streams (Upper Three } \\
\text { Runs, Four Mile Branch, and Tim's Branch) is } \\
\text { not included in the CA document. It also } \\
\text { appears that references to studies and } \\
\text { documentation are not provided. The CA } \\
\text { should, at a minimum, contain concise, but } \\
\text { complete, explanations of critical } \\
\text { hydrogeologic conuiiions. It is clear that the } \\
\text { direction of ground water flow and the } \\
\text { complex relationship of aquifers at various } \\
\text { depths and locations throughout the GSA with } \\
\text { surface water units, influenced by confining } \\
\text { units of various thickness and continuity, are } \\
\text { major determinants of contaminant levels and } \\
\text { doses projected in the hydrologic modeling } \\
\text { analyses, and that the existence of the natural } \\
\text { hydrologic barriers (including the ground } \\
\text { water divide and the incision of the upper } \\
\text { aquifer by the three streams) is highly } \\
\text { dependent upon flow conditions presented in } \\
\text { this document. To provide SRS management }\end{array}$ & $\begin{array}{l}\text { Comment noted. The next CA } \\
\text { revision will attempt to provide a } \\
\text { clearer description of the complex } \\
\text { hydrologic Conditions at SRS. }\end{array}$ \\
\hline
\end{tabular}




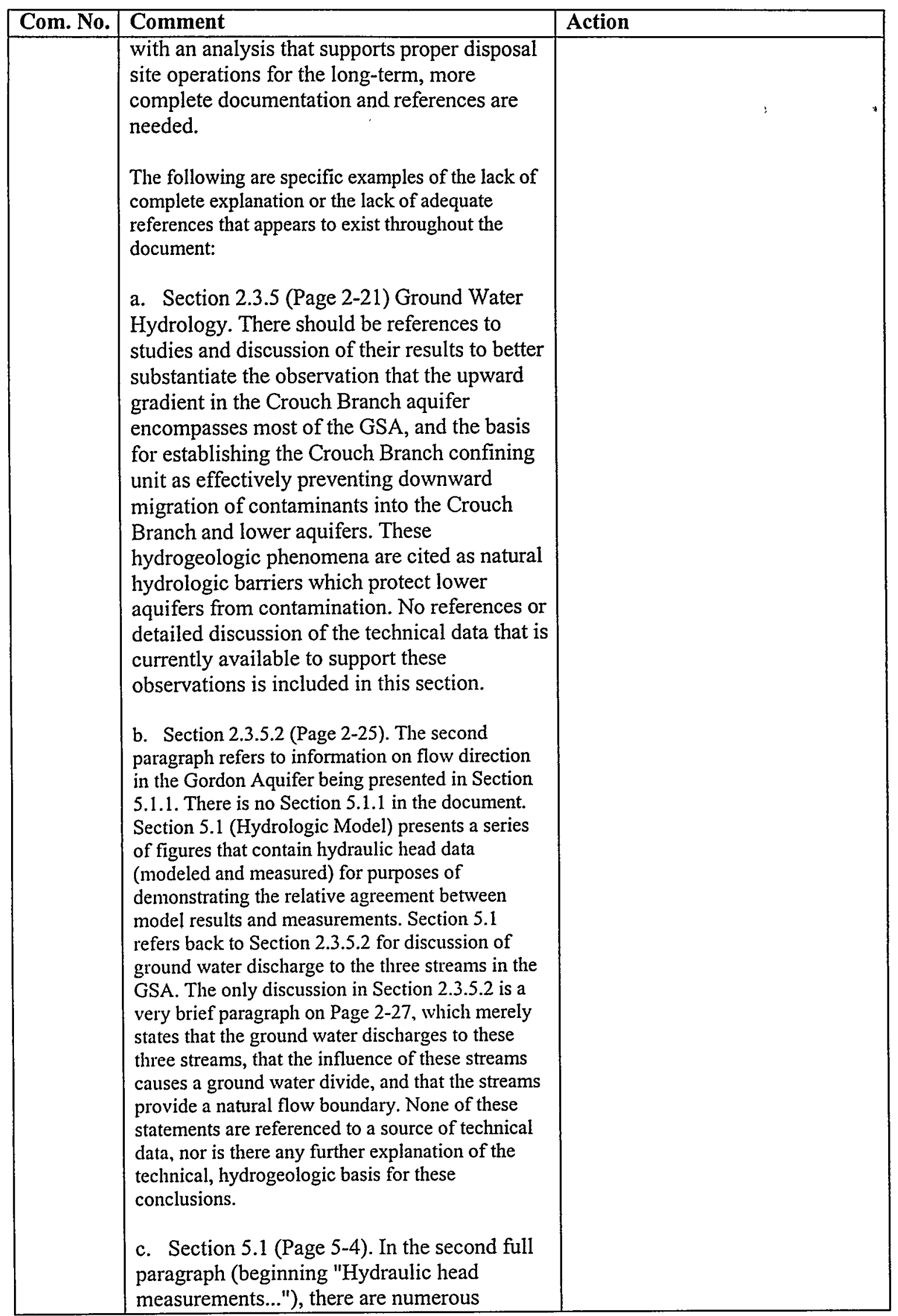




\begin{tabular}{|c|c|c|}
\hline Com. No. & Comment & Action \\
\hline & $\begin{array}{l}\text { statements that are not referenced nor fully } \\
\text { explained. This entire section is very crucial } \\
\text { to understanding the conceptual model of the } \\
\text { GSA and to quantifying the relationship of } \\
\text { ground water units to surface water streams } \\
\text { and the resulting modeling of contaminant } \\
\text { transport. There should be a more complete } \\
\text { discussion of the technical bases for these } \\
\text { observations, there should be references } \\
\text { provided, and there should be explanations of } \\
\text { assumed boundary conditions and how they } \\
\text { were quantified in the flow model. References } \\
\text { in Section 5.1 to discussions in Section } \\
\text { 2.3.5.2, as noted above, is an example of } \\
\text { cross-referencing in this document to another } \\
\text { equally incomplete discussion, rather than to a } \\
\text { full discussion or to another referenceable } \\
\text { source. } \\
\text { d. Section 5.1 (Page 5-26). In the first full } \\
\text { paragraph, the statement is made that "The } \\
\text { hydrologic model was used to generate an } \\
\text { average flow field for the GSA." This } \\
\text { predicted flow field data - which is crucial to } \\
\text { the accurate prediction of the movement of } \\
\text { radionuclides in the subsurface and their } \\
\text { control by natural hydrologic barriers - should } \\
\text { be verified by performing a water balance } \\
\text { analysis in the GSA. Using the conceptual } \\
\text { model, water inputs to the Gordon and the } \\
\text { Upper Three Runs aquifers and discharges to } \\
\text { the three streams should be developed based } \\
\text { on existing data on precipitation, subsurface } \\
\text { flow and storage, withdrawals and } \\
\text { reinjections (i.e., pump and treat at F \& H } \\
\text { Areas), and water table elevation } \\
\text { measurements. Such a water balance would } \\
\text { provide more credibility to the reliance on } \\
\text { natural hydrologic barriers, if based on actual } \\
\text { data accumulated over a sufficient period of } \\
\text { time. The details of the data collection } \\
\text { needed, and the development of the water } \\
\text { balance are appropriate matters to determine } \\
\text { in the context of the CA, and performed } \\
\text { during CA maintenance. }\end{array}$ & \\
\hline
\end{tabular}




\section{INTERPRETATION OF RESULTS/CONCLUSIONS}

\begin{tabular}{|c|c|c|}
\hline Com. No. & Comment & Action \\
\hline 105 & $\begin{array}{l}\text { Section } 7.4 \text { - It is silly to state that the only } \\
\text { change that might increase the dose is a } \\
\text { change in the land use. Obviously that could } \\
\text { be a very big one but there are numerous } \\
\text { others including the inventory that could } \\
\text { increase the dose. This section really should } \\
\text { list the assumptions and bases that are critical } \\
\text { to the analyses and which are going to be } \\
\text { compared during the periodic reviews. }\end{array}$ & See the response to Condition 4 . \\
\hline 106 & $\begin{array}{l}\text { The calculated results do not clearly satisfy } \\
\text { this requirement. The hydrology model does } \\
\text { not provide convincing evidence that the } \\
\text { regional aquifer system is well represented to } \\
\text { the west of the GSA. For the individual PAs, } \\
\text { this particular concern is not as relevant as the } \\
\text { CA, where the potential release of } \\
\text { contaminated groundwater to the soils and } \\
\text { swamps near the Savannah River could } \\
\text { introduce additional pathways for exposure. } \\
\text { As discussed in the site visit, there was no } \\
\text { data or verification step to ensure that mass } \\
\text { was conserved in the hydrology model } \\
\text { beyond the observation that the theory of the } \\
\text { model supported the conservation of mass. } \\
\text { The graphical results of the hydrology } \\
\text { suggested that mass may not be conserved } \\
\text { within the domain considered by the model. } \\
\text { Additional graphical results indicated the } \\
\text { zones of concern within the domain were } \\
\text { associated with areas of low velocity. While } \\
\text { the concern is less important, the additional } \\
\text { results do not clearly indicate that mass is } \\
\text { being conserved within the model domain. } \\
\text { The importance of the groundwater divide is } \\
\text { discussed in the CA and was discussed during } \\
\text { the site visit. The movement of the ivater table } \\
\text { was suggested to be }+/-5 \text { feet from episodic } \\
\text { events and the groundwater data suggested the } \\
\text { divide did not shift that much from episodic } \\
\text { events. Considering the significance of the } \\
\text { groundwater divide in the transport of } \\
\text { contamination, the low velocities of water } \\
\text { near the divide, the concern over the } \\
\text { conservation of mass, and the potential } \\
\text { movement of the divide, the sensitivity } \\
\text { analysis of the results should include the } \\
\text { consideration of changes in the location of the }\end{array}$ & $\begin{array}{l}\text { See the response to Condition } 2 \text {. } \\
\text { Future revisions of the CA will } \\
\text { have a more detailed } \\
\text { interpretation section. }\end{array}$ \\
\hline
\end{tabular}




\begin{tabular}{|c|c|c|}
\hline Com. No. & Comment & Action \\
\hline & $\begin{array}{l}\text { groundwater divide. The results of this } \\
\text { analysis should be addressed as an important } \\
\text { consideration in the interpretation of results. } \\
\text { The relationship between Fig. } 4.4-11 \text { and } \\
5.2-15 \text { is less than clear. The steady release of } \\
{ }^{99} \mathrm{Tc} \text { from the old burial ground in Fig } 4.4-11 \\
\text { is not clearly represented in Fig. } 5.2-15 \text {. In } \\
\text { addition, the notion of a steady state release } \\
\text { from the old burial grounds is questionable. } \\
\text { The justification for a release of }{ }^{233} \mathrm{U} \text { and }{ }^{238} \mathrm{U} \\
\text { from the old burial ground without a } \\
\text { corresponding release of }{ }^{234} \mathrm{U} \text { from the old } \\
\text { burial ground is questionable, as shown in } \\
\text { Figs. } 4.4-12,4.4-13 \text {, and } 4.4-14 \text {. } \\
\text { At the site visit, the long delay in the transport } \\
\text { of "129 was attributed to the vadose zone } \\
\text { thickness of } 60 \text { ft. This does not seem justified } \\
\text { by other radionuclides with similar mobilities } \\
\text { and other sources of the same radionuclide } \\
\text { that do not have the similar sort of delay. } \\
\text { Something is seriously wrong with Table } \\
6.1-1 . \text { Figures } 5.5-2 \text { and } 5.5-3 \text { identify the } \\
\text { dose from drinking water for FMB and UTR } \\
\text { for }{ }^{1+} \mathrm{C} \text { and }{ }^{3} \mathrm{H} \text {. The doses from these figures } \\
\text { are not consistent with the table. The dose for } \\
\text { one radionuclide could increase, as it has for } \\
{ }^{3} \mathrm{H} \text {, but the dose cannot decline for the other } \\
\text { radionuclide. Perhaps there is an explanation, } \\
\text { but none is provided. }\end{array}$ & \\
\hline 107 & $\begin{array}{l}\text { The CA provides an interpretation of the } \\
\text { calculated results and the sensitivity and } \\
\text { uncertainty results with respect to the dose } \\
\text { constraint and the dose limit at the point of } \\
\text { assessment and time period of assessment. } \\
\text { The results are less than the dose constraint } \\
\text { for all of the cases considered. As noted in } \\
\text { other comments with respect to the CA, the } \\
\text { logic, correctness, and rigor associated with } \\
\text { these interpretations is not clearly presented } \\
\text { or justified. }\end{array}$ & $\begin{array}{l}\text { See the responses to Conditions } 1 \\
\text { and } 4 .\end{array}$ \\
\hline 108 & $\begin{array}{l}\text { The results of the CA indicate the maximum } \\
\text { dose is } 14 \text { mrem/year, which is less than the } \\
\text { dose constraint of } 30 \text { mrem/year. } \\
\text { Consequently, and options analysis is not } \\
\text { required and is not included in the CA. The }\end{array}$ & Comment noted. \\
\hline
\end{tabular}




\begin{tabular}{|c|c|c|}
\hline Com. No. & Comment & Action \\
\hline & $\begin{array}{l}\text { dose of } 14 \mathrm{mrem} / \text { year is the dose from the } \\
\text { consumption of drinking water from FMB. } \\
\text { This potential scenario is considered to be a } \\
\text { sensitivity case and not a base case. }\end{array}$ & \\
\hline 109 & $\begin{array}{l}\text { The need for an ALARA assessment is } \\
\text { presented in the CA for the results included in } \\
\text { the CA. The presentation in the CA } \\
\text { demonstrates there is no need for an ALARA } \\
\text { assessment to identify any actions to further } \\
\text { reduce the doses. Presuming the results of the } \\
\text { analysis provide a complete, composite } \\
\text { analysis of the SRS, this conclusion is } \\
\text { justified. }\end{array}$ & Comment noted. \\
\hline 110 & $\begin{array}{l}\text { The CA does not provide a comparison to the } \\
\text { PA to allow an evaluation of this requirement. } \\
\text { The CA does not admit a resident scenario } \\
\text { and the drinking water calculations in the CA } \\
\text { are performed at a larger distance from the } \\
\text { source than in the PA. }\end{array}$ & $\begin{array}{l}\text { Results presented in Table } 4.4-5 \\
\text { for the disposal units in the EAV } \\
\text { and Saltstone facilities provide } \\
\text { the comparison. Future revisions } \\
\text { of the CA will provide a more } \\
\text { explicit comparison. }\end{array}$ \\
\hline 111 & $\begin{array}{l}\text { The maximum projected dose over the period } \\
\text { of assessment is presented, but without a clear } \\
\text { and consistent definition of the point of } \\
\text { assessment. }\end{array}$ & See the response to Condition 1. \\
\hline 112 & $\begin{array}{l}\text { The need for the ALARA assessment is } \\
\text { presented and concludes an ALARA } \\
\text { assessment is not warranted. The calculated } \\
\text { population dose is } 3 \text { person-rem/year, } \\
\text { allowing a cost of } \$ 30,000 \text { per person-rem } \\
\text { averted. The CA concludes the analysis of the } \\
\text { options in the CA exceeds this maximum } \\
\text { value. }\end{array}$ & Comment noted. \\
\hline 113 & $\begin{array}{l}\text { An options analysis was not performed for the } \\
\text { CA because the resulting dose reported in the } \\
\text { CA was less than the dose constraint. }\end{array}$ & Comment noted. \\
\hline 114 & $\begin{array}{l}\text { This particular requirement is associated with } \\
\text { the rigor of the analysis presented in the CA. } \\
\text { Numerous sources have been excluded } \\
\text { without justification and the point of } \\
\text { assessment is not well justified. The analysis } \\
\text { does not provide bounding calculations for the } \\
\text { many uncertain variables associated with the } \\
\text { CA. As a result, the CA does not provide a } \\
\text { clear case that the analysis is a reasonable } \\
\text { representation of the existing site knowledge. }\end{array}$ & See the response to Condition 1 . \\
\hline 115 & $\begin{array}{l}\text { Section } 1.0 \text { I don't believe the results of the } \\
\text { CA clearly show there will be NO adverse } \\
\text { health impact. The numbers presented are } \\
\text { indeed less than the dose constraints and } \\
\text { performance objectives but they are based on }\end{array}$ & Comment noted. \\
\hline
\end{tabular}




\begin{tabular}{|c|c|c|}
\hline Com. No. & Comment & Action \\
\hline & $\begin{array}{l}\text { a less than robust or complete analysis. How } \\
\text { this section will need to be reworded will be } \\
\text { based on the resolution of the comments. }\end{array}$ & \\
\hline 116 & $\begin{array}{l}\text { The composite analysis does not include } \\
\text { discussion or evaluation of potential off-site } \\
\text { sources such as the Barnwell low level waste } \\
\text { disposal facility, or a commercial nuclear } \\
\text { facility located up river from the Savannah } \\
\text { River Site. }\end{array}$ & $\begin{array}{l}\text { Such discussion is not required if } \\
\text { the dose constraint is met as is the } \\
\text { case in the CA. }\end{array}$ \\
\hline 117 & $\begin{array}{l}\text { SRS CA Requirement; Page } 7-2 \text {, section } 7.4 \\
\text { first paragraph states "The maximum peak } \\
\text { dose of } 14 \text { mrem/yr calculated for the GSA in } \\
\text { this analysis is considerably lower..." The } \\
\text { above referenced paragraph is inconsistent } \\
\text { with the Supplemental information provided } \\
\text { in "Bounding Estimate of All GSA } \\
\text { Contaminants Migrating to Either of the } \\
\text { Streams." This analysis shows at an estimated } \\
\text { dose of } \sim 30.8 \text { mrem/year which is over the } \\
\text { dose constraint of the CA. }\end{array}$ & $\begin{array}{l}\text { Bounding (worst case) estimates } \\
\text { are not appropriate for } \\
\text { determining compliance with the } \\
\text { CA dose constraint. }\end{array}$ \\
\hline 118 & $\begin{array}{l}\text { a. The ground water divide is a critical } \\
\text { hydrologic factor in any analysis of the } \\
\text { potential future impact on the environment of } \\
\text { low-level waste disposal at the GSA. } \\
\text { b. More careful, detailed analyses of the } \\
\text { estimated impacts on drinking water and } \\
\text { recreational exposures should be performed to } \\
\text { better define the sensitivity of the CA doses to } \\
\text { changes in this and other critical hydrologic } \\
\text { factors. Such analyses should include } \\
\text { estimated doses through the drinking water } \\
\text { pathway at the mouth of the Upper Three } \\
\text { Runs and Four Mile Branch streams, as well } \\
\text { as at the Highway } 301 \text { Bridge. } \\
\text { c. Studies designed to measure and quantify } \\
\text { hydrogeologic factors, as well as the influence of } \\
\text { site activities at the surface, should be designed } \\
\text { and conducted to further quantify the hydrologic } \\
\text { response of the ground water divide (as well as the } \\
\text { other natural hydrologic barriers). Modeling } \\
\text { studies are a first step, but longer term monitoring } \\
\text { and aquifer stress tests are needed to quantify the } \\
\text { likely response of the flow system to future } \\
\text { conditions, all of which may impact the } \\
\text { dimensions, as well as the existence and the } \\
\text { effectiveness, of the ground water divide. } \\
\text { d. Although the sensitivity analysis indicates } \\
\text { that estimated doses are highest for tritium, } \\
\text { there are other radionuclides with longer } \\
\text { half-lives, that may be of greater concern. } \\
\text { There should be a more detailed analysis of }\end{array}$ & $\begin{array}{l}\text { See the responses to Conditions } 1 \\
\text { and } 2 .\end{array}$ \\
\hline
\end{tabular}




\begin{tabular}{|c|c|c|}
\hline Com. No. & Comment & Action \\
\hline & $\begin{array}{l}\text { the potential impact of other "significant" } \\
\text { radionuclides which consider both the } \\
\text { drinking water and the recreational scenarios } \\
\text { at the GSA, at the mouths of both streams, } \\
\text { and at the Highway } 301 \text { Bridge. } \\
\text { If a more thorough analysis indicates that } \\
\text { potential doses reach or exceed } 30 \text { mrem/year, } \\
\text { there will be the need for an options analysis } \\
\text { for examining means for reducing potential } \\
\text { doses further, by applying ALARA. }\end{array}$ & \\
\hline 119 & $\begin{array}{l}\text { The CA presents conclusions that the } \\
\text { long-term performance of the disposal facility } \\
\text { and other contributing sources is less than the } \\
\text { dose constraint. The demonstration of these } \\
\text { conclusions is the source of many comments } \\
\text { included in this review. The logic correctness, } \\
\text { and rigor of the conclusions reached in the } \\
\text { CA warrant additional review prior to } \\
\text { acceptance. }\end{array}$ & $\begin{array}{l}\text { The conditions of approval given } \\
\text { by LFRG have been met by } \\
\text { publication of this addendum. }\end{array}$ \\
\hline 120 & $\begin{array}{l}\text { The CA results are less than } 30 \text { mrem/year, } \\
\text { the need for an ALARA assessment is } \\
\text { presented, and the results show an ALARA } \\
\text { assessment is not required. However, the } \\
\text { need for preparing an options analysis is } \\
\text { concluded using the results from the } \\
\text { sensitivity analysis of the consumption of } \\
\text { water from FMB, and not from the base case } \\
\text { in CA that did not include the consumption of } \\
\text { surface water. At this particular point of the } \\
\text { CA, the conclusions are being drawn from the } \\
\text { wrong results. This further underscores the } \\
\text { many difficulties with the identification of the } \\
\text { point of assessment throughout the CA. }\end{array}$ & See the response to Condition 1 . \\
\hline 121 & $\begin{array}{l}\text { This requirement does not currently apply to } \\
\text { the SRS CA. }\end{array}$ & Comment noted. \\
\hline 122 & $\begin{array}{l}\text { This requirement does not currently apply to } \\
\text { the SRS CA. }\end{array}$ & Comment noted. \\
\hline 123 & $\begin{array}{l}\text { Section } 7.3 \text { of the CA concludes that potential } \\
\text { doses are unlikely to exceed the dose } \\
\text { constraint. Given the uncertainties in the } \\
\text { conceptual and numerical groundwater flow } \\
\text { models, it is not unreasonable to postulate } \\
\text { conditions that would result in exceedance of } \\
\text { the dose constraint. Acceptance of the CA } \\
\text { should be conditional upon completion of a } \\
\text { more thorough uncertainty analysis and any } \\
\text { options analysis that may be required based } \\
\text { upon those results. }\end{array}$ & See the response to Condition 2 . \\
\hline
\end{tabular}




\begin{tabular}{|c|c|c|}
\hline Com. No. & Comment & Action \\
\hline 124 & $\begin{array}{l}\text { In the Summary and Conclusions, Page 1-1, } \\
\text { the statement is made in the first paragraph } \\
\text { that the results of the CA clearly indicate that } \\
\text { continued disposal will have no adverse } \\
\text { impact on future members of the public. This } \\
\text { conclusion is highly dependent upon the } \\
\text { assumption that institutional control will } \\
\text { effectively prevent human exposure to } \\
\text { radiological contaminants and will prevent } \\
\text { human activities that may disrupt the flow } \\
\text { system characteristics that provide natural } \\
\text { hydrologic barriers. It is misleading to state } \\
\text { that the CA results are based on dose } \\
\text { calculations that not only justify the statement } \\
\text { that no adverse impact would occur, but } \\
\text { justify not performing additional sensitivity } \\
\text { analyses or options/ALARA analyses to } \\
\text { reduce doses further. It is critical that this } \\
\text { document state that the conclusions of the CA } \\
\text { are based on the recommendations included in } \\
\text { a future land use plan. } \\
\text { No one. can predict the future, and even } \\
\text { though many of us believe that the SRS, as it } \\
\text { exists today, will continue to remain a } \\
\text { restricted federal defense facility for a very } \\
\text { long. time, there is a need for some assurances } \\
\text { regarding maintaining the site's status. (Order } \\
\text { USDOE } 5400.5 \text { requirements must be met } \\
\text { before the site can be released, but there is no } \\
\text { discussion of how or whether this requirement } \\
\text { will be met, or what is in place to assure that } \\
\text { the site will not be released.) Absent any other } \\
\text { legally binding commitment to, maintaining } \\
\text { restricted use of the existing site for a specific } \\
\text { period of time or "in perpetuity", it is } \\
\text { necessary to qualify all conclusions by stating } \\
\text { the overall assumptions upon which they were } \\
\text { based. } \\
\text { To provide an illustration of the need for } \\
\text { consistent use of qualifying statements when } \\
\text { providing conclusions on the CA results, the } \\
\text { additional information provided by WSRC in } \\
\text { the } 4 / 21 / 98 \text { memo from W. Noll contains a } \\
\text { re-analysis of the potential doses calculated } \\
\text { water indicates that the estimated dose }\end{array}$ & Comment noted. \\
\hline
\end{tabular}




\begin{tabular}{|c|c|c|}
\hline Com. No. & Comment & Action \\
\hline & $\begin{array}{l}\text { from the drinking water pathway at Four Mile } \\
\text { Branch at the GSA for tritium is } 64 \\
\text { mrem/year, which is } 16 \text { times greater than the } \\
\text { MCL. However, WSRC concludes that this } \\
\text { level of exposure would never occur because } \\
\text { overly conservative assumptions were used } \\
\text { (all contaminants migrate to one stream rather } \\
\text { than being partitioned to two streams due to } \\
\text { the ground water divide, and no correction } \\
\text { was made for the added decay of tritium in a } \\
\text { longer migration pathway) and the calculated } \\
\text { peak dose would occur at } 62 \text { years, which is } \\
\text { well within the time period where exposure } \\
\text { would be prevented by institutional controls, } \\
\text { according to future land use plans. In this } \\
\text { case, the results of the analysis exceed the } \\
\text { MCL and the } 30 \text { mrem/year point where an } \\
\text { options analysis would be needed. So the } \\
\text { analysts provide qualifying statements that } \\
\text { acknowledge the implications of the } \\
\text { assumptions that were used. The same type of } \\
\text { qualifications are needed when drawing } \\
\text { conclusions that there will be no adverse } \\
\text { impacts on the general public in the future. }\end{array}$ & 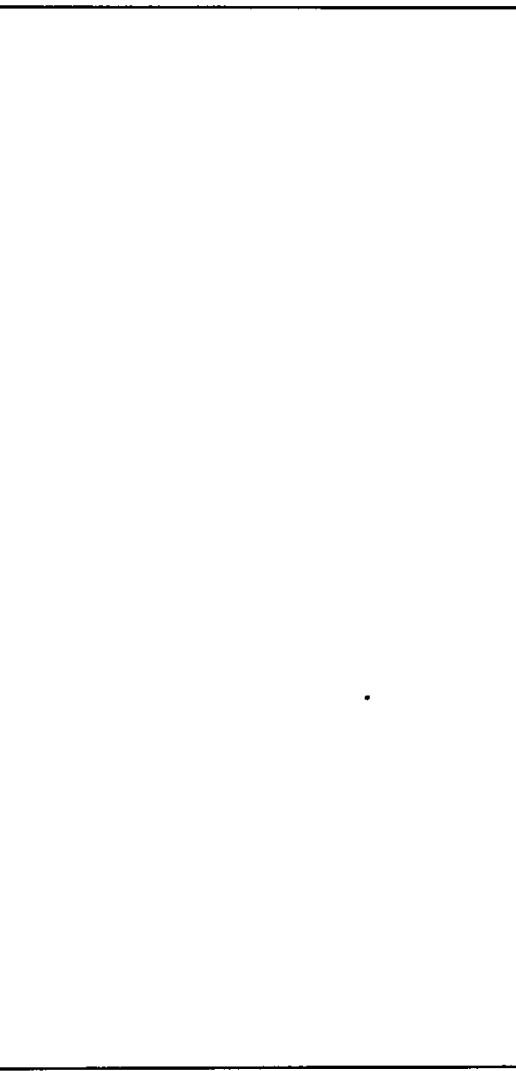 \\
\hline 125 & $\begin{array}{l}\text { SRS CA Requirement, Supplemental } \\
\text { "Assessment of Impact of A and M Area } \\
\text { Sources on Composite Analysis Results." The } \\
\text { sixth paragraph states "For each radionuclide, } \\
\text { the concentration in Upper Three Runs from } \\
\text { the GSA sources (i.e. that analyzed in the CA) } \\
\text { is greater than that from the Tims Branch } \\
\text { sources. The ratio of concentration the UTR } \\
\text { to that in the Tims Branch ranges from } 29 \text { for } \\
{ }_{238} \mathrm{U} \text { to } 29 \text { million for tritium. Thus the Tims } \\
\text { Branch watershed will make a negligible } \\
\text { contribution of potential doses to the public } \\
\text { calculated at the mouth of Upper Three } \\
\text { Runs." } \\
\text { Internal radiation exposure from multiple } \\
\text { radionuclides is a cumulative effect not a } \\
\text { singular event. All radionuclide sources and } \\
\text { their respective dose contributions to the } \\
\text { off-site receptor should be calculated and } \\
\text { summed to determine if the off-site dose } \\
\text { criteria has been met. }\end{array}$ & Comment noted. \\
\hline 126 & $\begin{array}{l}\text { SRS CA Requirement, Supplemental } \\
\text { "Bounding Estimate of All GSA } \\
\text { Contaminants Migrating to Either of the }\end{array}$ & See the response to Condition 3 . \\
\hline
\end{tabular}




\begin{tabular}{|c|c|c|c|}
\hline Com. No. & \multicolumn{2}{|l|}{ Comment } & Action \\
\hline & \multicolumn{2}{|c|}{$\begin{array}{l}\text { Streams." The included table (no table } \\
\text { number assigned) under the column; } \\
\text { "Estimated Dose form Recreation Scenario at } \\
\text { FMB Mouth" indicates a current dose from } \\
\mathrm{C}^{1+} \text { of } 28.8 \text { mrem/year. } \\
\text { The indicated table does not include the dose } \\
\text { contribution from the A and M areas, and it } \\
\text { should be noted that the indicated dose of } 28.8 \\
\text { mrem/yr is close to the } 30 \text { mrem/yr dose } \\
\text { criteria for the CA. It should also be noted } \\
\text { that the cumulative estimated dose at the } \\
\text { mouth of FMB is } \sim 30.8 \text { mrem/yr. It is } \\
\text { imperative that the CA source term be } \\
\text { reevaluated to include the estimated dose } \\
\text { from all radionuclides and that the effect on } \\
\text { the down stream receptor site be determined. } \\
\text { Additionally, there is no mention in the CA as } \\
\text { to how future development on the opposite } \\
\text { bank of the Savannah River will be guided. }\end{array}$} & \\
\hline 127 & \multicolumn{2}{|c|}{$\begin{array}{l}\text { The conclusions of the CA are based on a } \\
\text { limited interpretation of the results and the } \\
\text { bases for the analysis presented in the CA. } \\
\text { Since the results indicated that potential doses } \\
\text { were less than the dose constraint, as long as } \\
\text { access to the SRS was restricted in perpetuity, } \\
\text { and that conservative assumptions were } \\
\text { selected in preparing the CA, there was no } \\
\text { apparent need to conduct a detailed } \\
\text { examination of the assumptions in the CA and } \\
\text { their effect on the results. }\end{array}$} & Comment noted. \\
\hline \multicolumn{4}{|c|}{$\begin{array}{l}\text { Notes: } \\
\text { Acronyms are generally not spelled out in the table due to space limitations. The Comment column in the table may contain } \\
\text { acronyms that are spelled out since this column represents direct quotations from the Comment document. The following acronyms } \\
\text { are used in the table. }\end{array}$} \\
\hline $\begin{array}{l}\text { D\&D } \\
\text { USDOE } \\
\text { DQO } \\
\text { DWPF } \\
\text { EAV } \\
\text { EPA } \\
\text { FMB } \\
\text { GSA } \\
\text { HLW } \\
\text { HQ } \\
\text { ILT }\end{array}$ & $\begin{array}{l}\text { As Low As Reasonably Achievable } \\
\text { Composite Analysis } \\
\text { Comprehensive Environmental Response, } \\
\text { Compensation, and Liability Act } \\
\text { Decontamination and Demolition } \\
\text { U.S. Department of Energy } \\
\text { Data Quality Objectives } \\
\text { Defense Waste Processing Facillty } \\
\text { E-Area Vaults } \\
\text { U.S. Environmental Protection Agency } \\
\text { Fourmile Branch } \\
\text { General Separations Area } \\
\text { High-Level Waste } \\
\text { Headquarters } \\
\text { Intermediate-Level Trench }\end{array}$ & $\begin{array}{l}\text { LAW } \\
\text { LFRG } \\
\text { LLW } \\
\text { MCL } \\
\text { NRC } \\
\text { OBG } \\
\text { PA } \\
\text { RCRA } \\
\text { ROD } \\
\text { SRL } \\
\text { SRS } \\
\text { SRTC } \\
\text { UTR } \\
\text { WSRC }\end{array}$ & $\begin{array}{l}\text { Low-Activity Waste } \\
\text { Low-Level Waste Facilities Federal } \\
\text { Review Group } \\
\text { Low-Level Waste } \\
\text { Maximum Contaminant Level } \\
\text { U.S. Nuclear Regulatory Commission } \\
\text { Old Burial Ground } \\
\text { Performance Assessment } \\
\text { Resource Conservation and Recovery } \\
\text { Act } \\
\text { Record of Decision } \\
\text { Savannah River Laboratory } \\
\text { Savannah River Site } \\
\text { Savannah River Technology Center } \\
\text { Upper Three Runs } \\
\text { Westinghouse Savannah River Company }\end{array}$ \\
\hline
\end{tabular}




\subsection{Condition 6}

Discussion of the environmental monitoring program, inclusion of environmental monitoring data, and comparison with the expected results from the composite analysis.

\subsection{Comparison with Environmental Monitoring Program}

\subsubsection{Environmental Monitoring Program}

SRS looks for, identifies, and quantifies its released contaminants through an extensive environmental monitoring program. This program's main components are effluent monitoring and environmental surveillance. Samples of air, water, and other media are collected and analyzed to determine the presence of contaminants from site operations. Results are used to monitor effects on natural resources and human health and also to demonstrate compliance with regulations. These results are published each year in the SRS Environmental Report which is made available to the public.

Much of the onsite monitoring is done by the Environmental Protection Department's Environmental Monitoring Section and by the Savannah River Technology Center. Groups outside the SRS also monitor the site. These include the South Carolina Department of Health and Environmental Control and the Georgia Department of Natural Resources.

\subsubsection{Effluent Monitoring}

Effluent monitoring is the collection of samples at the point where materials are released from the facilities and their subsequent analysis. Two types of effluent monitoring are done at SRS. Radiological effluent monitoring looks for radionuclides that are released from the facilities. More than 4,400 radiological samples were collected and analyzed during 1996. Nonradiological effluent monitoring looks for nonradioactive materials that are released from the facility.

\subsubsection{Environmental Surveillance}

Environmental surveillance covers more that 31,000 square miles and extends up to 100 miles from the site. With results of this surveillance, scientists attempt to assess contaminants that may have spread into the environment. Like effluent monitoring, environmental surveillance can be both radiological and nonradiological.

\subsubsection{Radiological Releases}

Radionuclides released from the site can travel through the environment, potentially causing exposure to the offsite public. Routes that contaminants may follow through the environment are called pathways. Airborne release pathways include (1) inhalation and (2) the consumption of locally produced foods and milk, contaminated by deposition of the airborne contaminants; liquid release pathways include the consumption of (1) fish, (2) shellfish from downriver in the Savannah River estuary, and (3) Savannah River water. Monitoring groundwater migration from contaminated areas on the site is important in determining liquid releases.

\subsubsection{Radiological Surveillance}

Routine surveillance is performed on the atmosphere (air and rainwater), surface water (site streams and the Savannah River), drinking water, food products (terrestrial and aquatic), wildlife, 
soil, sediment, vegetation, and groundwater. Monitoring of gamma radiation in the environment is conducted on site, at the site boundary, and in surrounding communities.

\subsection{Comparison of Environmental Monitoring Data with Composite Analysis Results}

Data from the last two annual monitoring reports are compared with CA results in Table 6.2-1. The monitoring reports give annual average radionuclide concentrations in SRS streams. These concentrations were used to calculate radiological dose by assuming consumption of 2 liters of stream or river water per day for a year. These doses are presented along with the doses calculated in the CA as a "reality check" on the CA results. The numbers are in good agreement, with those for the Savannah River being closest and those for UTR being farthest apart. 
Table 6.2-1 Monitoring Data and Composite Analysis Results Comparison

\begin{tabular}{|lccc|}
\hline Stream & $\begin{array}{c}\text { From 1996 } \\
\text { Monitoring } \\
(\mathrm{mrem} / \mathrm{yr})\end{array}$ & $\begin{array}{c}\text { From 1997 } \\
\text { Monitoring } \\
(\mathrm{mrem} / \mathrm{yr})\end{array}$ & $\begin{array}{c}\text { From Composite Analysis } \\
(\mathrm{mrem} / \mathrm{yr})\end{array}$ \\
\hline Upper Three Runs & $0.11^{\mathrm{a}}$ & $0.15^{\mathrm{c}}$ & $2.4^{\mathrm{e}}$ \\
Fourmile Branch & $9.7^{\mathrm{a}}$ & $9.9^{\mathrm{c}}$ & $2 e^{\mathrm{e}}$ \\
Savannah River & $0.05^{\mathrm{b}}$ & $0.05^{\mathrm{d}}$ & $0.08^{\mathrm{f}}$ \\
\hline
\end{tabular}

Notes:

a Based on concentration given in Savannah River Site Environmental Report for 1996, WSRCTR-97-0171, Table 6-4, page 83.

b Based on concentration given in Savannah River Site Environmental Report for 1996, WSRCTR-97-0171, Table 6-5, page 85.

c Based on concentration given in Savannah River Site Environmental Report for 1997, WSRCTR-97-00322, Table 6-3, page 91.

d Based on concentration given in Savannah River Site Environmental Report for 1996, WSRCTR-97-00322, Table 6-4, page 94.

e From Composite Analysis, WSRC RP-97-311, Table 6.1-1, page 6-2.

$f$ From Composite Analysis, WSRC RP-97-311, Table 5.5-2, page 5-73. 
THIS PAGE INTENTIONALLY LEFT BLANK 


\subsection{Condition 7}

Inclusion of the information that Savannah River Site committed to be incorporated in the composite analysis maintenance plan over the course of the composite analysis review.

During preparation of this addendum, the authors discussed this condition with J. N. Perry, the Review Team leader. Mr. Perry indicated his understanding that the commitments had been captured in the minutes of the Review Team meetings. The authors then discussed the Review Team minutes with R. U. Curl. The LFRG Technical Secretary. Mr. Curl indicated that no commitments for incorporation of information in the SRS Maintenance Plan are noted in the review team minutes.

The authors believe that all of the items discussed with the Review Team regarding what would be in the SRS Maintenance Plan have, in fact, been incorporated into the plan (Attachment 1). 


\section{Attachment 1}

Maintenance Program for the E-Area Vaults and Saltstone Performance Assessments, and the Composite Analysis 
THIS PAGE INTENTIONALLY LEFT BLANK 

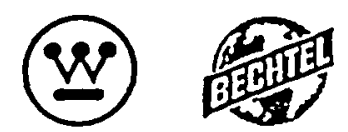

BNFL

SWD-99-0040
Mr. William L. Noll, Director

Solid Waste Division

U.S. Department of Energy

Savannah River Operations Office

P. O. Box A

Aiken, South Carolina 29802
Mr. Howard B. Gnann, Director

Programs Division

U.S. Department of Energy

Savannah River Operations Office

P. O. Box A

Aiken, South Carolina 29802

Dear Messrs. Noll and Gnann:

\section{MAINTENANCE PROGRAM FOR THE E-AREA VAULTS AND SALTSTONE PERFORMANCE ASSESSMENTS, AND THE COMPOSITE ANALYSIS}

Ericlosed is the subject Performance Assessment (PA) and Composite Analysis (CA) Maintenance Program. We have incorporated the elements of the PAs for both low-level waste disposal facilities (Saltstone and EArea), and the CA into one plan to ensure work that is applicable to all efforts is not duplicated, but rather is applied in a synergistic fashion across all areas.

Also, we have included the necessary elements of a PA/CA Maintenance Program as reflected in draft DOE Order 435.1 and the Complex-Wide Strategy for Maintenance of DOE Low-Level Waste Disposal Facility PAs and CAs, dated September 30, 1998 (transmitted by letter from James Owendoff, DOE, to John Conway, DNFSB, 10/1/98).

The enclosed PÁ/CA Maintenance Program is intended to satisfy the AOP milestone to "Update the PA. Maintenance Plan by $4 / 30 / 99$ to support development of the AOP and long-range planning." As agreed with your staff, we provided a draft $4 / 27 / 99$ for your review. This attachment includes your staff's comments and represents a modification of the plan to provide the Alternative Trench Disposal.Evaluation in FY99. Instead, we will provide a Special Analysis for. Components-in-Grout in FY99 and provide direct assistance in implementation of trench disposal in FY00. As we agreed, the Components-in-Grout Special Analysis will not expand the uncertainty evaluations, but rather uncertainty will be addressed in the PA Revision: Our response to DOE's comments on the PA Revision will be provided in July 1999, and a modified PA Revision that contains the response resolutions will be provided in FY00. In addition, this PA Maintenance Program provides the information to satisfy the conditions of approval for the Saltstone PA.

Any questions you or your staff may have may be directed to me or to W. T. Goldston of my staff.

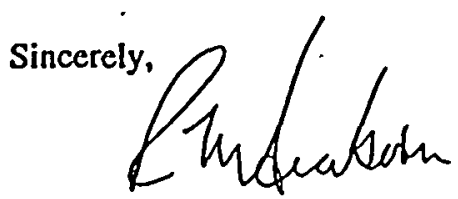

Richard M. Seaborn

Deputy Manager \& Chief Engineer

Solid Waste Division

wtg/fg

Enc. 
William L. Noll

Howard B. Gnann .

SWD-99-0040

Page 2

MAY 187999

c: G. R. Hannah, 703-H

V. Sauls, 703-A.

R. J. Schepens, 704-S

W. Smith, 703-A

H. H. Burns, 724-21E

B. T. Butcher, 773-43A

J. R. Cook, 773-43A

C. C. Crawford, 705-3C

R. T. Duke, 705-3C

W.T. Goldston, 705-3C

P. I. Hudson, 705-3C

H. J. Kinder, 261-4H

T. D. Lookabill, 241-168H

C. W. McVay, 704-43H

J. W. Paveglio, 705-3C

J. E. Simpson, 724-36E

W. E. Stevens, 773-A

L. C. Thomas, 724-7E

E. L. Wilhite, 773-43A

Document Control, 705-3C 


\title{
MAINTENANCE PROGRAM FOR THE \\ E:AREA VAULTS AND SALTSTONE PERFORMANCE ASSESSMENTS, AND THE COMPOSITE ANALYSIS
}

\author{
FY99 IMPLEMENTATION PLAN
}

\section{EXECUTIVE SUMMARY}

The Performance Assessments (PAs) for both the E-Area Vaults (EAV) and Saltstone disposal facilities assess the calculated dose impact on the public from the respective radioactive disposal sites to verify compliance with Department of Energy (DOE) performance standards. The Composite Analysis (CA) is a management tool whose purpose is to assist DOE in assessing the possible impacts on the public and environment from multiple sources of radioactive material at a site (such as SRS) in order to determine where DOE may need to focus attention or take mitigating actions. The DOE, through its Implementation PIan for DNFSB 94-2 and its Waste Management Order (draft DOE Order 435.1), requires the maintenance of both the EAV and Saltstone PAs and the CA. Because the PA and CA results are in part based on technically uncertain data, conservative parameters, or both, a maintenance program is needed to provide greater confidence in the results of the analyses and in the long-term plans for public and environmental protection. The preparation and execution of this plan is in compliance with the Complex-wide strategy for maintenance of both DOE PAs and CAs as reflected in draft DOE Order 435.1. The purpose of both the PA and CA maintenance programs (MAP) is to confirm the continued adequacy of the PA/CA and to increase confidence in the results of the PA/CA. The elements of the PA/CA MAP are:
1) Special Analyses
2) PA/CA Revisions
3) PA/CA Reviews
4) Monitoring
5) _. Tests and Research

The maintenance activities for the $\mathrm{CA}$ and the E-Area and Saltstone PA are summarized in Tables 1.A through 1.E. The budget supporting the PA/CA MAP activities is reflected in Table 1.F. Tables 1.F.a through Table 1.F.c reflect the respective budgets for maintaining the EAV PA, the Saltstone PA, and the CA. The MAP will reflect both PA and CA-related activities in the Annual Operating Plan (AOP) for each fiscal year and the outyears for ten-year budget planning purposes. PA and CA special analyses are discussed in Section I. A CA special analysis will be conducted as a subset of every PA special analysis. A CA special analysis will also be conducted whenever changes in the assumptions in the CA (e.g., land use, remediation, closure) occur. Section II includes discussion on PA and CA revisions which will be scheduled when required. The first CA revision will be conducted this fiscal year (FY99) and will include the WSRC response to the DOE Low-Level Waste Federal Review Group's (LFRG) "Conditions of · Approval" and will be documented as an addendum to the CA. In Section III, the various factors considered in the PA and CA annual review are discussed. The annual reviews will consider factors such as site future land use plans, changes in remediation and closure plans, and changes in source terms. The monitoring program that will be developed to allow validation of the PA and CA by comparing actual monitoring data with PA/CA results is discussed in Section IV. In Section V, the test and research program that supports the PA and $C A$ is discussed. The initial test and research activities will be conducted to reduce the uncertainty of the results. Each of these five program elements is discussed in further detail in this document. 
Table 1A: Summary Table for PA \& CA Maintenance Program - Special Analyses

\begin{tabular}{|c|c|c|c|c|c|c|c|c|c|c|c|c|}
\hline Thapecial & 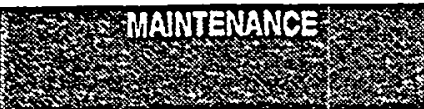 & $x y$ & Elo & PYo & & 28 & (17ros & 2ys & 8 & SW7 & 28 & costs \\
\hline A. EAV PA & 1. Altemalive Trench Disposal & & $x$ & & & & & & & & & $\$ 80 \mathrm{~K}$ \\
\hline & 2. Evaluate ${ }^{129}$ | Waste Disposal & $6 / 30$ & $\bar{x}$ & & & & & & & & & $\begin{array}{l}\text { (2525KM) } \\
\$ 50 \mathrm{~K}\end{array}$ \\
\hline & 3. Wood PA Considerations & & $\bar{x}$ & & & & & & & & & $\$ 50 \mathrm{~K}$ \\
\hline & 4. Naval Fuels EU & & & $x$ & & & & & & & & $\$ 50 \mathrm{~K}$ \\
\hline & 5. Reactor Deionizers ${ }^{14} \mathrm{C}$ & & $\bar{x}$ & & & & & & & $\cdot$ & & $\$ 30 \mathrm{~K}$ \\
\hline & 6. Glass Waste Forms & & $\mathrm{X}$ & & & & & & & & & $\$ 50 \mathrm{~K}$ \\
\hline & 7. Sealed Sources $-{ }^{137} \mathrm{Cs}$ & & $\bar{x}$ & & & & & & & & & $\$ 50 \mathrm{~K}$ \\
\hline & 8a. Closure Plan & & $\bar{x}$ & & & & & & $\cdot$ & & & $\$ 85 K$ \\
\hline & $\begin{array}{l}\text { 8b. Incorporate DOE Comments } \\
\text { on Closure Plan }\end{array}$ & & & $\bar{X}$ & & & & & & & & $\$ 45 K$ \\
\hline & 9. Components in Grout & $\mathrm{X}$ & $\bar{x}$ & & & & & & & & & $\begin{array}{l}(\$ 40 \mathrm{KM}) \\
\$ 80 \mathrm{~K}\end{array}$ \\
\hline & $\begin{array}{l}\text { 10. Equipment with Lead Shielding } \\
\text { and Counterweights }\end{array}$ & $\bar{x}$ & $\bar{x}$ & & & & & & & & & $\begin{array}{l}(\$ 25 \mathrm{KM} \\
\$ 50 \mathrm{~K}\end{array}$ \\
\hline & 11. Environmental Restoration & & & $\bar{x}$ & $\bar{x}$ & $x$ & & & $\mathrm{X}$ & & & 4 \\
\hline & 12. MOX, Pit Dis, Pu Imob & & & $\bar{x}$ & $x$ & $\underline{x}$ & $x$ & $\bar{X}$ & $\mathrm{X}$ & & & ** \\
\hline & 13. Tritium Extraction Facility & & $\underline{x}$ & $\bar{x}$ & $\mathrm{X}$ & & & & & & & *t* \\
\hline & 14. D\&D Waste Forms & & & & & $\mathrm{X}$ & $\bar{x}$ & $\bar{X}$ & $\mathrm{X}$ & $\mathrm{X}$ & $\bar{x}$ & \# \\
\hline & 15. Special/Problem Waste Forms & & & & $\bar{x}$ & $\bar{x}$ & $\bar{x}$ & $\bar{x}$ & $\bar{x}$ & $x$ & $x$ & $\begin{array}{l}1550 \mathrm{KM} \\
\$ 350 \mathrm{~K}\end{array}$ \\
\hline & EAV PA TOTAL & $\$ 90 K$ & $\$ 435 K$ & $\$ 95 K$ & $\$ 50 \%$ & $\$ 50 K$ & SSOK & $\$ 50 \%$ & $\$ 50 K$ & $\$ 50 \mathrm{~K}$ & $\$ 50 \%$ & $\$ 970 \mathrm{~K}$ \\
\hline$\overline{B . C A}$ & $\begin{array}{l}\text { 1. Altemate Trench Disposal } \\
\text { Concepts }\end{array}$ & & $\bar{x}$ & & & & & & & & & $\$ O K^{*}$ \\
\hline & 2. Disposal of 129! Waste & $6 / 30$ & $x$ & & & & & & & & & $\$ \mathrm{OK}^{*}$ \\
\hline & 3. Glass Waste Forms & & $\bar{x}$ & $\dot{-}$ & & & & & & & & $\$ \mathrm{OK}^{*}$ \\
\hline 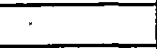 & 4. Sealed Sources $-{ }^{137} \mathrm{Cs}$ & & $\bar{x}$ & & & & & & & & & $\$ \mathrm{OK}^{*}$ \\
\hline & $\begin{array}{l}\text { 5. Effect of Altemate Salt } \\
\text { Decontamination on } \\
\text { Saltstone Process }\end{array}$ & & $\begin{array}{l}\text { Con- } \\
\text { tingent } \\
\text { on DOE }\end{array}$ & & & & & & & & & $\$ \mathrm{OK}^{*}$ \\
\hline & 6. Components in Grout/CA & & $\bar{x}$ & & & & & & & & & $\mathrm{SOK}^{*}$ \\
\hline & 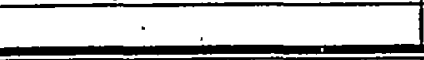 & & & & & & & & & CATC & TAL: & $\$ O K$ \\
\hline $\begin{array}{l}\text { C. Salistone } \\
\text { PA }\end{array}$ & $\begin{array}{l}\text { 1. Effect of Altemate Salt } \\
\text { Decontamination on Saltstone } \\
\text { Process }\end{array}$ & & $\begin{array}{c}\text { Con- } \\
\text { tingent } \\
\text { on DOE }\end{array}$ & & & & - & & & & & $\$ 50 \mathrm{~K}$ \\
\hline & $\begin{array}{l}\text { 2. Closure Plan Review and DOE } \\
\text { comment Incorporation }\end{array}$ & & $\bar{x}$ & : & & & & & & & & $\$ 60 \mathrm{~K}$ \\
\hline & & & & & & & & SALI & STON & EPAT & OTAL & $\$ 110 K$ \\
\hline $\begin{array}{l}\text { GRAND } \\
\text { TOTAL }\end{array}$ & $\begin{array}{l}\text { Total of EAV PA, CA Salistone PA } \\
\text { Special Analyses }\end{array}$ & $\$ 90 \mathrm{~K}$ & $\$ 545 K$ & $\$ 95 \mathrm{~K}$ & $\$ 50 \mathrm{~K}$ & $\$ 50 \mathrm{~K}$ & $\$ 50 \mathrm{~K}$ & $\$ 50 \mathrm{~K}$ & $\$ 50 \mathrm{~K}$ & $\$ 50 \mathrm{~K}$ & $\$ 50 \mathrm{~K}$ & $\$ 1,080 \mathrm{~K}$ \\
\hline
\end{tabular}

* Included in PA Maintenance Bưget

** Funded by Project ( $\$ 50 \mathrm{~K}$ per year) 
Table 1B: Summary Table for PA \& CA Maintenance Program - PA/CA Revision

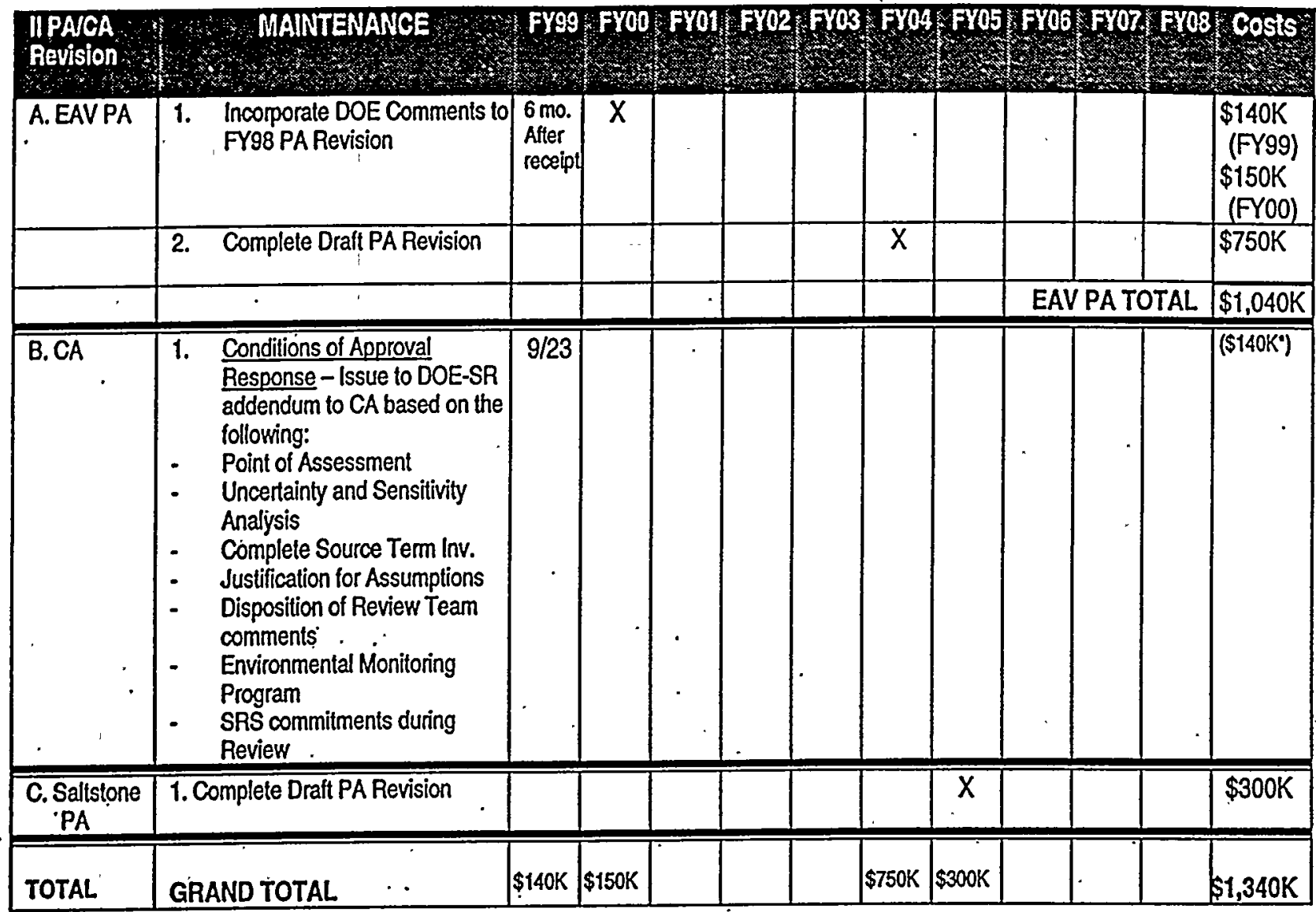

* Included in PA Maintentrace Budget :

Table 1C: Summâry Table for PA \& CA Maintenance Program-PA/CA Annual Review

\begin{tabular}{|c|c|c|c|c|c|c|c|c|c|c|c|c|}
\hline III Annual & M MANTENA & FY99 & FYoo & FYoI & 6702 & ro3 & PYo & FYOS & 1FY60 & FYo? & FY08 & Costs \\
\hline A. EAVPA & 1. Annual Review & 1298 & $x$ & $\mathrm{x}$ & $x$ & $\mathrm{x}$ & $\mathrm{x}$ & $\bar{x}$ & $\mathrm{x}$ & $\mathrm{x}$ & $\mathrm{x}$ & $\begin{array}{l}\$ 30 K Y \\
(\$ 300 K)\end{array}$ \\
\hline$\overline{B . C A}$ & 1. Annual Review & & $\bar{x}$ & $\bar{x}$ & $\bar{x}$ & $\overline{\bar{X}}$ & $\bar{x}$ & $\bar{x}$ & $\bar{x}$ & $\bar{x}$ & $\bar{x}$ & $\begin{array}{l}\$ 50 K Y \\
(\$ 450 K)\end{array}$ \\
\hline $\begin{array}{c}\text { C. Salistone } \\
\text { PA }\end{array}$ & 1. Annual Review & $5 / 31$ & $\bar{X}$ & $\bar{x}$ & $\bar{x}$ & $\bar{x}$ & $\bar{x}$ & $\overline{\mathrm{X}}$ & $\bar{x}$ & $\bar{x}$ : & $\bar{x}$ & $\begin{array}{l}\$ 30 \mathrm{KN}^{*} \\
(\$ 300 \mathrm{~K})\end{array}$ \\
\hline DTAL. & GRAND TOTAL & $\$ 60 \mathrm{~K}$ & $\$ 110 \mathrm{~K}$ & $\$ 110 \mathrm{~K}$ & $\$ 110 \mathrm{~K}$ & $\$ 110 \mathrm{~K}$ & $\$ 110 k$ & $\$ 110 \mathrm{~K}$ & $\$ 110 \mathrm{~K}$ & $\$ 110 k$ & $\$ 110 K$ & $\$ 1,050 \mathrm{~K}$ \\
\hline
\end{tabular}

- Recommend Saltstone PA Annual Review be curtailed until an alternative to ITP is chosen. Saltstone is not expected to operate again until after such a decision. 
Table 1D: Summary Table for PA \& CA Maintenance Program - Monitoring

\begin{tabular}{|c|c|c|c|c|c|c|c|c|c|c|c|c|}
\hline $\begin{array}{l}\text { WMonito } \\
\text { oring }\end{array}$ & (3) & Ereg & 7rop & Brot & Froz: & 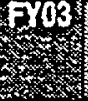 & 8 & I & 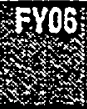 & 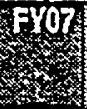 & Fro8 & Costis \\
\hline A. EAVPA & $\begin{array}{l}\text { 1. Vadose Zone (VZ) } \\
\text { Installation - } 3 \text { Boreholes } \\
\text { around existing Trenches }\end{array}$ & $9 / 30$ & . & & & & & & & & & $\$ 295 K^{*+1+}$ \\
\hline & $\begin{array}{l}\text { 2. VZ Installation -9 } \\
\text { Boreholes around } \\
\text { existing Trenches }\end{array}$ & & $\bar{x}$ & & & & & & & & & $\$ 393 K^{*+*}$ \\
\hline & $\begin{array}{l}\text { 3. VZ Installation around } \\
\text { LAW and IL Vaults }\end{array}$ & & $\mathrm{X}$ & & & & & & & & & $\$ 966 \mathrm{~K}$ \\
\hline & $\begin{array}{l}\text { 4. VZ Installation around } \\
\text { Future Trenches }\end{array}$ & & & $\bar{x}$ & & & & & & & & $\$ 745 K$ \\
\hline & $\begin{array}{l}\text { 5. Install Groundwater } \\
\text { wells around Future } \\
\text { Trenches } \\
\end{array}$ & & & & $x$ & & & & & & & $\$ 362 \mathrm{~K}$ \\
\hline & 6. Site Monitoring Program & & & & & $\underline{x}$ & $x$ & $x$ & $\frac{x}{501}$ & $\frac{x}{104}$ & $\frac{X}{x-1}$ & $\$ 0 K^{* *}$ \\
\hline & & & & & & & & & \multicolumn{3}{|c|}{ EAV PA TOTAL } & $\$ 2,761 \mathrm{~K}$ \\
\hline B.CA & $\begin{array}{l}\text { 1. Develop Protocol for } \\
\text { CA Validation }\end{array}$ & & $\bar{x}$ & & & & & & & & & $\$ 30 \mathrm{~K}$ \\
\hline & $\begin{array}{l}\text { 2. Conduct Annual CA } \\
\text { Validation }\end{array}$ & & & $\bar{x}$ & $\bar{x}$ & $\bar{x}$ & $x$ & $\bar{x}$ & $\bar{x}$ & $x$ & $\bar{x}$ & $\begin{array}{l}\$ 10 \mathrm{KN} \\
(\$ 80 \mathrm{~K})\end{array}$ \\
\hline & & & & & & & & & \multicolumn{3}{|c|}{ CA TOTAL } & $\$ 110 \mathrm{~K}$ \\
\hline $\begin{array}{l}\text { C. Sallitone } \\
\text { PA }\end{array}$ & $\begin{array}{l}\text { 1. Develop Protocol for } \\
\text { Saltstone PA. } \\
\text { Validation }\end{array}$ & & $\bar{x}$ & & & & & & & & & $\$ 40 \mathrm{~K}$ \\
\hline & $\begin{array}{l}\text { 2. Conduct Annual } \\
\text { Saltstone PA } \\
\text { - Validation }\end{array}$ & & & $\bar{x}$ & $\bar{x}$ & $\bar{x}$ & $\bar{x}$ & $\bar{x}$ & $\bar{x}$ & $\bar{x}$ & $\bar{x}$ & $\begin{array}{l}\$ 10 K N \\
(\$ 80 K)\end{array}$ \\
\hline & & & & & & & & & \multicolumn{3}{|c|}{ SALTSTONE PA TOTAL } & $\$ 120 \mathrm{~K}$ \\
\hline TOTAL & GRAND TOTAL & $\$ 295 K$. & $\begin{array}{l}\$ 1,429 \\
K\end{array}$ & $\$ 765 K$ & $\$ 382 K$ & $\$ 20 \mathrm{~K}$ & $\$ 20 \mathrm{~K}$ & $\$ 20 \mathrm{~K}$ & $\$ 20 \mathrm{~K}$ & $\$ 20 \mathrm{~K}$ & $\$ 20 \mathrm{~K}$ & $\$ 2,991 \mathrm{~K}$ \\
\hline
\end{tabular}

** Budgeted under Site Monitoring Program

*** ASTD will fund a portion of these costs in FY99/FY00 
- Table 1E: Summary Table for PA \& CA Maintenance Program - Test \& Research

\begin{tabular}{|c|c|c|c|c|c|c|c|c|c|c|c|c|c|}
\hline $\begin{array}{l}\text { West } 8 \\
\text { Research } \\
\text { Program }\end{array}$ & +8 & MANRTENANCE & Frag & 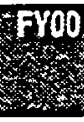 & FO1 & $8 \times$ & 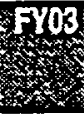 & FYa4 & 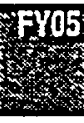 & 8 & From & FYo8 & Casts \\
\hline A. EAVPA & $\begin{array}{l}\text { PAN } \\
\text { Activ }\end{array}$ & $\begin{array}{l}\text { MAP Test \& Research } \\
\text { ities }\end{array}$ & & & & & & & & & & & \\
\hline & 1 & $\begin{array}{l}\text { Qualify and Expand } \\
\text { Pathrae/Compare } \\
\text { Groundwater Modeling } \\
\text { Codes } \\
\end{array}$ & - & $\bar{x}$ & & & & & & & & & $\$ 100 K^{\circ}$ \\
\hline & 2 & $\begin{array}{l}\text { Obtain Kd Data for Organic } \\
\text { Material } \\
\end{array}$ & $\begin{array}{l}\text { Com. } \\
\text { plete }\end{array}$ & & & & & & & & & 1 & $\$ O K$ \\
\hline & 3 & $\begin{array}{l}\text { Develop Experimental } \\
\text { Capability to Obtain Kd Data }\end{array}$ & & $\bar{x}$ & $\bar{x}$ & $\bar{x}$ & $\bar{x}$ & $\bar{x}$ & $\bar{x}$ & $\bar{x}$ & $\bar{x}$ & $\bar{x}$ & $\begin{array}{l}\$ 130 K \\
\text { FYO0; } \\
\$ 50 K N \\
\text { after } \\
\text { Total: } \\
\$ 530 K)\end{array}$ \\
\hline & 4 & $\begin{array}{l}\text { Benchmark PORFLOW vs. } \\
\text { BLT-EC }\end{array}$ & & $\bar{x}$ & $\bar{x}$ & $\bar{x}$ & $\bar{x}$ & $\bar{x}$ & $\bar{x}$ & $\bar{x}$ & $\bar{x}$ & $\bar{x}$ & $\begin{array}{l}\$ 100 K \text { in } \\
\text { FYo0; } \\
\$ 25 K N \\
\text { after } \\
\text { (Total: } \\
\$ 300 K) \\
\end{array}$ \\
\hline & 5 & $\begin{array}{l}\text { Model Waste as Series of } \\
\text { Stirred Tanks }\end{array}$ & & & & & & & $\bar{x}$ & & & & $\$ 50 \mathrm{~K}$ \\
\hline & 6 & $\begin{array}{l}\text { Model CracksNault } \\
\text { Collapse } \\
\end{array}$ & & & & $\bar{x}$ & & & & & & & $\$ 100 \mathrm{~K}$ \\
\hline & 7 & \begin{tabular}{|l|} 
Model Sum-of Fractions \\
Using Timing of Doses \\
\end{tabular} & & $x$ & & & & & & & & & $\$ 50 \mathrm{~K}$ \\
\hline & 8 & Radon Dose Calculations & & & & & & $\mathrm{x}$ & & & & & $\$ 50 \mathrm{~K}$ \\
\hline & 9 & $\begin{array}{l}\text { Model Moisture Flow in } \\
\text { Vadose Zone } \\
\end{array}$ & & & & & & & $x$ & & & & $\$ 100 K$ \\
\hline & 10 & $\begin{array}{l}\text { Improve Computer Model; } \\
\text { Techniques to Integrate } \\
\text { Boundary Conditions } \\
\end{array}$ & & $\bar{x}$ & $\bar{x}$ & $\bar{x}$ & $\bar{x}$ & $\bar{x}$ & $\bar{x}$ & $\bar{x}$ & $\bar{x}$ & & $\begin{array}{l}\text { \$50KY } \\
\text { (Total: } \\
\text { \$400K) } \\
\end{array}$ \\
\hline$?$ & 11 & \begin{tabular}{|l|} 
Delemine Wood \\
Degradation Products
\end{tabular} & $\bar{x}$ & & & & & & & & & & $\$ 60 \mathrm{~K}$ \\
\hline & 12. & $\begin{array}{l}\text { Develop Instrumentation to } \\
\text { Measure C-14, TC-99 }\end{array}$ & . & & $\therefore$ & $\therefore$ & & & & $\mathrm{x}$ & $\bar{x}$ & $\because$ & $\begin{array}{l}\text { \$200kN } \\
\text { (Total: } \\
\$ 400 \mathrm{~K}) \\
\end{array}$ \\
\hline & 13 & $\begin{array}{l}\text { Correlate Permeabitity and } \\
\text { Leachability for Asticrete } \\
\end{array}$ & $\bar{x}$ & & & & & . & & & & & $\$ 50 \mathrm{~K}$ \\
\hline & 14 & $\begin{array}{l}\text { Effect of grout structures } \\
\text { and fills on colloid formation }\end{array}$ & & $\bar{x}$ & $\bar{x}$ & & & & & & & & $\$ 45 K$ \\
\hline & & & & & . & & & & & & PATC & JTAL & $\$ 2235 \mathrm{~K}$ \\
\hline$\overline{B . C A}$ & 1. & $\begin{array}{l}\text { Study to reduce } \\
\text { uncertainty in C-14 } \\
\text { Dose }\end{array}$ & & & $\bar{x}$ & & & & & & & & $\$ 50 \mathrm{~K}$ \\
\hline & 2. & $\begin{array}{l}\text { Study to Consider } \\
\text { Closure Caps }\end{array}$ & & & & $\bar{x}$ & & & & & & & $\$ 50 \mathrm{~K}$ \\
\hline & & & & & & & & & & & CAT & OTAL & $\$ 100 \mathrm{~K}$ \\
\hline C. Sallstone & $\begin{array}{l}\text { EAVI } \\
\text { is app }\end{array}$ & $\begin{array}{l}\text { PA Test \& Research Activities } \\
\text { oficable to the Saltstone PA }\end{array}$ & & & & & & & & & & & $N A$ \\
\hline TOTAL & GRA & AND TOTAL & $\$ 110 \mathrm{~K}$ & $\$ 450 \mathrm{~K}$ & $\$ 200 \mathrm{~K}$ & $\$ 275 K$ & $\$ 125 K$ & $\$ 175 K$ & $\$ 275 \mathrm{~K}$ & $\$ 325 \mathrm{~K}$ & $\$ 325 \mathrm{~K}$ & $\$ 75 K$ & $\$ 2335 \mathrm{~K}$ \\
\hline
\end{tabular}


TABLE 1F: Summary Table for PA and CA Maintenance Budget (GRAND TOTAL: EAV PA, Saltstone PA, and CA)

\begin{tabular}{|c|c|c|c|c|c|c|c|c|c|c|c|}
\hline PAMAP & $8 \times 99$ & Xoo & $5 Y 01$ & 8502 & FYos & FYo4 & 8 & $\mathrm{YrOS}$ & FYo7 & SFyos & Total \\
\hline $\begin{array}{l}\text { I Special } \\
\text { Analyses }\end{array}$ & $\$ 90 \mathrm{~K}$ & $\$ 545 K$ & $\$ 95 \mathrm{~K}$ & $\$ 50 \mathrm{~K}$ & $\$ 50 \mathrm{~K}$ & $\$ 50 \mathrm{~K}$ & $\$ 50 \mathrm{~K}$ & $\$ 50 K$ & $\$ 50 \mathrm{~K}$ & $\$ 50 \mathrm{~K}$ & $\begin{array}{c}\$ 1,080 \mathrm{~K} \\
.\end{array}$ \\
\hline II Revisions & $\$ 140 \mathrm{~K}$ & $\$ 150 K$ & & & & $\$ 750 \mathrm{~K}$ & $\$ 300 \mathrm{~K}$ & & & & $\$ 1,340 \mathrm{~K}$ \\
\hline $\begin{array}{l}\text { III Annual } \\
\text { Reviews }\end{array}$ & $\$ 60 \mathrm{~K}$ & $\$ 110 K$ & $\$ 110 \mathrm{~K}$ & $\$ 110 \mathrm{~K}$ & $\$ 110 K$ & $\$ 110 K$ & $\$ 110 \mathrm{~K}$ & $\$ 110 K$ & $\$ 110 \mathrm{~K}$ & $\$ 110 K$ & $\$ 1,050 \mathrm{~K}$ \\
\hline IV Monitoring & $\$ 295 K$ & $\$ 1,429 \mathrm{~K}^{\circ}$ & $\$ 765 K$ & $\$ 382 \mathrm{~K}$ & $\$ 20 K$ & $\$ 20 \mathrm{~K}$ & $\$ 20 \mathrm{~K}$ & $\$ 20 K$ & $\$ 20 K$ & $\$ 20 \mathrm{~K}$ & $\$ 2,991 \mathrm{~K}$ \\
\hline $\begin{array}{l}\text { VTests \& } \\
\text { Research }\end{array}$ & $\$ 110 \mathrm{~K}$ & $\$ 450 \mathrm{~K}$ & $\$ 200 \mathrm{~K}$ & $\$ 275 K$ & $\$ 125 K$ & $\$ 175 \mathrm{~K}$ & $\$ 275 K$ & $\$ 325 \mathrm{~K}$ & $\$ 325 K$ & $\$ 75 K$ & $\$ 2,335 \mathrm{~K}$ \\
\hline Total & $\$ 695 K$ & $\$ 2,684 K^{*}$ & $\$ 1,170 \mathrm{~K}$ & $\$ 817 K$ & $\$ 305 K$ & $\$ 1,105 K$ & $\$ 755 K$ & $\$ 505 K$ & $\$ 505 K$ & $\$ 255 \mathrm{~K}$ & $\$ 8,796 K$ \\
\hline
\end{tabular}

* A portion of the monitoring budget will be funded by ASTD in FY99/00.

TABLE 1Fa: Summary Table for EAV PA Maintenance Budget

\begin{tabular}{|c|c|c|c|c|c|c|c|c|c|c|c|}
\hline $\begin{array}{l}\text { PAMAP } \\
\text { Element }\end{array}$ & FY99 & Froo & 601 & FY02 & & Fros & ryos & & FYor & FYos & Total \\
\hline $\begin{array}{l}\text { Special } \\
\text { Analyses }\end{array}$ & $\$ 90 \mathrm{~K}$ & $\$ 435 \mathrm{~K}$ & $\$ 95 K$ & $\$ 50 \mathrm{~K}$ & $\$ 50 \mathrm{~K}$ & $\$ 50 \mathrm{~K}$ & $\$ 50 \mathrm{~K}$ & $\$ 50 \mathrm{~K}$ & $\$ 50 \mathrm{~K}$ & $\$ 50 \mathrm{~K}$ & $\$ 970 \mathrm{~K}$ \\
\hline II Revisions & $\$ 140 \mathrm{~K}$ & $\$ 150 \mathrm{~K}$ & $\cdots$ & & & $\$ 750 K$ & & & & & $\$ 1,040 \mathrm{~K}$ \\
\hline $\begin{array}{l}\text { III Annual } \\
\text { Reviews }\end{array}$ & $\$ 30 K$ & $\$ 30 \mathrm{~K}$ & $\$ 30 \mathrm{~K}$ & $\$ 30 \mathrm{~K}$ & $\$ 30 K$ & $\$ 30 K$ & $\$ 30 \mathrm{~K}$ & $\$ 30 \mathrm{~K}$ & $\$ 30 \mathrm{~K}$ & $\$ 30 K$ & $\$ 300 \mathrm{~K}$ \\
\hline IV Monitoring & \$295K & $\$ 1,359 K^{*}$ & $\$ 745 \mathrm{~K}$ & $\$ 362 K$ & $\$ O K$ & \$OK & $\$ O K$ & SOK & $\$ O K$ & $\$ O K$ & $\$ 2,761 \mathrm{~K}$ \\
\hline $\begin{array}{l}\text { V Tests \& } \\
\text { Research }\end{array}$ & $\$ 110 \mathrm{~K}$ & $\$ 450 \mathrm{~K}$ & $\$ 150 \mathrm{~K}$ & $\$ 225 \mathrm{~K}$ & $\$ 125 K$ & $\$ 175 K$ & $\$ 275 K$ & $\$ 325 K$ & $\$ 325 K$ & $\$ 75 K$ & $\$ 2,235 \mathrm{~K}$ \\
\hline Total & $\$ 665 \mathrm{~K}$ & $\$ 2,424 K^{\circ}$ & $\$ 1,020 \mathrm{~K}$ & $\$ 667 \mathrm{~K}$ & $\$ 205 \mathrm{~K}$ & $\$ 1,005 \mathrm{~K}$ & $\$ 355 \mathrm{~K}$ & $\$ 405 K$ & $\$ 405 \mathrm{~K}$ & $\$ 155 K$ & $\$ 7,306 \mathrm{~K}$ \\
\hline
\end{tabular}

* A portion of the monitoring budget will be funded by ASTD in FY99/00. 
TABLE 1F.b: Summary Table for CA Maintenance Budget

\begin{tabular}{|c|c|c|c|c|c|c|c|c|c|c|c|}
\hline $\begin{array}{l}\text { PAMAP } \\
\text { Element }\end{array}$ & 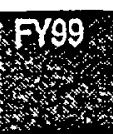 & FYOO & FYo1 & $5 Y 02$ & Fro & Fro4 & FYos & $\mathrm{FYO}$ & Pro & Fyo & Tola \\
\hline $\begin{array}{l}\text { Special } \\
\text { Analyses }\end{array}$ & & & & & & & & & & & \$OK" \\
\hline II Revisions & $\$ 1.40 K^{* * 1 *}$ & & & & & & & & & & $\$ O K^{* *}$ \\
\hline $\begin{array}{l}\text { III Annual } \\
\text { Reviews }\end{array}$ & , & $\$ 50 \mathrm{~K}$ & $\$ 50 \mathrm{~K}$ & $\$ 50 \mathrm{~K}$ & $\$ 50 \mathrm{~K}$ & $\$ 50 \mathrm{~K}$ & $\$ 50 \mathrm{~K}$ & $\$ 50 \mathrm{~K}$ & $\$ 50 \mathrm{~K}$ & $\$ 50 \mathrm{~K}$ & $\$ 450 \mathrm{~K}$ \\
\hline IV Monitoring & & $\$ 30 \mathrm{~K}$ & $\$ 10 K$ & $\$ 10 K$ & $\$ 10 \mathrm{~K}$ & $\$ 10 K$ & $\$ 10 K$ & $\$ 10 K$ & $\$ 10 \mathrm{~K}$ & $\$ 10 K$ & $\$ 110 K$ \\
\hline $\begin{array}{l}\text { VTests \& } \\
\text { Research }\end{array}$ & & & $\$ 50 \mathrm{~K}$ & $\$ 50 \mathrm{~K}$ & & & & & & & $\$ 100 \mathrm{~K}$ \\
\hline Total & $\$ O K^{* * *}$ & $\$ 80 K$ & $\$ 110 K$ & $\$ 110 K$ & $\$ 60 \mathrm{~K}$ & $\$ 60 \mathrm{~K}$ & $\$ 60 \mathrm{~K}$ & $\$ 60 \mathrm{~K}$ & $\$ 60 \mathrm{~K}$ & $\$ 60 \mathrm{~K}$ & $\$ 660 \mathrm{~K}$ \\
\hline
\end{tabular}

** CA Special Analyses are funded through the PA Special Analyses budget.

*** Response to CA ."Conditions of Approval" is funded in the EAV PA Budget for FY99.

\section{TABLE 1Fc: Summary Table for Saltstone PA Maintenance Budget}

\begin{tabular}{|c|c|c|c|c|c|c|c|c|c|c|c|}
\hline $\begin{array}{l}\text { PAMAP } \\
\text { Element }\end{array}$ & FY99 & FYoO & FYo1 & FYo2 & FYos & FYo & Pros & $\begin{array}{r}\mathrm{PYo}^{2} \\
8\end{array}$ & $\mathrm{FYO}$ & POog & Total \\
\hline $\begin{array}{l}\text { Special } \\
\text { Analyses }\end{array}$ & ${ }^{11} \quad \therefore$ & $\$ 110 \mathrm{~K}$. & $\cdots$ & $\because$ & & ( & & & & & $\$ 110 K$ \\
\hline II Revisions & ' & & . & $\because$ & & & $\$ 300 K$ & & & $\theta$ & $\$ 300 K$ \\
\hline $\begin{array}{l}\text { III Annual } \\
\text { Reviews }\end{array}$ & $\$ 30 \mathrm{~K}$ & $\$ 30 \mathrm{~K}^{*}$ & $\$ 30 K$ & $\$ 30 K$ & $\$ 30 K$ & $\$ 30 \mathrm{~K}$ & $\$ 30 \mathrm{~K}$ & $\$ 30 \mathrm{~K}$ & $\$ 30 \mathrm{~K}$ & $\$ 30 K$ & $\$ 300 \mathrm{~K}$ \\
\hline IV Monitoring & & $\$ 40 \mathrm{~K}$ & $\$ 10 K$ & $\$ 10 K$ & $\$ 10 \mathrm{~K} \cdot$ & $\$ 10 \mathrm{~K}$ & $\$ 10 \mathrm{~K}$ & $\$ 10 \mathrm{~K}$ & $\$ 10 K$ & $\$ 10 \mathrm{~K}$ & $\$ 120 \mathrm{~K}$ \\
\hline $\begin{array}{l}\text { VTests \& } \\
\text { Research }\end{array}$ & & & & & & & & & & & $\$ O K^{* \cdots+1}$ \\
\hline Total & $\$ 30 \mathrm{~K}$ & $\$ 180 K$ & $\$ 40 \mathrm{~K}$ & $\$ 40 \mathrm{~K}$ & $\$ 40 K$ & $\$ 40 K$ & $\$ 340 \mathrm{~K}$ & $\$ 40 K$ & $\$ 40 \mathrm{~K}$ & $\$ 40 K$ & $\$ 830 \mathrm{~K}$ \\
\hline
\end{tabular}

- Recommend Saltstone Annual Review be curtailed until the altemative to ITP is decided.

**** Tests and Research for Saltstone funded under EAV PA MAP budget. 


\section{SPECIAL ANALYSES}

The following waste types or waste disposal methodologies have been identified as requiring special analysis (SA) for the EAV PA, CA, and Saltstone PA. These analyses will be issued as an addendum for the respective PAs/CA.

\section{A. EAV PA Special Analyses}

1. Evaluate Alternative Trench Disposal Concepts - FY00

a. Description: A team of Solid Waste Division and SRTC PA experts is planned to determine the best way to implement trench disposal of large equipment (in grout), compacted job control waste, non-compactable, and non-incinerable waste. Evaluations will include co-mingling of waste forms, alternative trench designs (e.g., drive-in vs narrow), subsidence considerations, and operations procedure development. The evaluations will ensure that operations are conducted within the bounds of important PA parameters and assumptions.

b. Milestone: Issue SA or separate report on alternative trench disposal concepts.

c. Due Date: $9 / 00$

d. Responsibility: Solid Waste Division (SWD)/ Savannah River Technology Center (SRTC)

e. Estimated Cost: $\$ 80 \mathrm{~K}$

2. Evaluate Disposal of Waste Containing ${ }^{129}$ I (ETF Carbon Filters \& F/H Groundwater Treatment) FY99

a. Description: ETF has determined that activated carbon filter columns prepared for disposal in the E-Area LLW Disposal facilities contain high ${ }^{129}$ I concentrations. These columns contain ${ }^{129}$ I concentrations that exceed PA Inventory Limits. Funding is provided in FY99 for Savannah River Technology Center to review PA credit options for the high ${ }^{129}$ I concentration in the columns.

Environmental Restoration (ER) has solidified basin sludge from their Groundwater : Remediation Project that contains ${ }^{129}$ I concentrations that are higher than the LAW Vault WAC concentration limit as well. This administrative limit was established by the PA inventory requirements for ${ }^{129} \mathrm{I}$ in the LAW Vault. Funding is provided in FY99 for SRTC to review PA credit options for the high ${ }^{129} \mathrm{I}$ coricentration in the sludge. Assistance is' expected to be required in FYOO as well.

b. Milestone: Issue SA or separate report on credit options for disposal of ${ }^{129} \mathrm{I}$ waste.

c. Due Date: $6 / 30 / 99$, FY00

d. Responsibility: SWD/SRTC

e. Estimated Cost: FY99 \$25K, FY00 $\$ 25 \mathrm{~K}$

3. Wood PA Considerations Requested by DOE - FYOO

a. Description: A SA titled "Performance Assessment of Trench Disposal of Wood Products (U)" was completed in FY96 to serve as additional information for the EAV PA Appendix I, "Suspect Soil Performance Assessment." The analysis demonstrated that wood products (i.e., railroad ties containing organics) can be disposed in soil trenches in compliance with DOE Order 5820.2A performance objectives. However, the wood $\mathrm{PA}$, as well as the original 
$\therefore$ suspect soil PA, did not take credit for a closure cap. Also, the analysis did not consider the impact of subsidence, based on SWD commitments to conduct waste management operations in a manner that minimized the impact (i.e., additional fill material, inspections, etc.). Finally the analysis included assumptions used in the models on the impact of the simplified organic system on sorption coefficients. The transmittal letter recognized that these assumptions would need to be confirmed with laboratory testing.

DOE conditionally approved the PA (Letter, Noll to Kelly, 10/28/96) with the stipulation that further analysis should be conducted on subsidence and on closure cap considerations. Therefore, SWD/SRTC plan to conduct studies that consider (1) a closure cap design, (2) a subsidence review and (3) lab studies of sorption coefficients. Lab studies of sorption coefficients were conducted in FY98 and have been extended into FY99. Once the studies. are completed, the PA will be revised with the laboratory data.

b. Milestone: Issue SA (EAV PA addendum) to include analysis on wood PA considerations.

c. Due Date: FYOO

\section{d. Responsibility: SWD/SRTC}

e. Estimated Cost: $\$ 50 \mathrm{~K}$

4. Evaluate Disposal of Naval Fuels Enriched Uranium - FY01

a. Description: The Naval Fuels facility utilized enriched uranium hexafluoride andmanufactured fuel for nuclear submarines. Much of the concentrated uranium waste now stored in the SRS Solid Waste Disposal Facility (SWDF) was off-specification material which was originally designated for recycle. The process was shut down before recycle could occur and the material was subsequently designated as waste. Burial is the most cost effective method to remove this waste from continuing care. SRS and others have buried enriched uranium through the years in shallow-land trenches. A preliminary PA analysis shows that this may be acceptable from aspects of migration to groundwater, safety, and intruder scenarios. Uranium can also be made more immobile by proper design of the burial facility with a barrier that will chemically tie up the uranium in the centuries to come. This option requires that a more detailed performance assessment be made of the trench area before dișposal can be effected.

b. Milestone: Issue SA (EAV PA addendum) on disposal of enriched uranium.

c. Due Date: FY01

d. Responsibility: SWD/SRTC

e. Estimated Cost: $\$ 50 \mathrm{~K}$

5. Evaluate EAV Disposal of Reactor Deionizers ${ }^{14} \mathrm{C}$ - FY00

a. Description: There are 48 reactor deionizer vessels containing resin in storage at SRS. With the reactors shut down, no more generation is anticipated. The deionizers, which were used to control the chemistry of the SRS reactor/moderator during operation, contain an appreciable amount of ${ }^{14} \mathrm{C}$. ${ }^{14} \mathrm{C}$ is a long-lived radionuclide (half-life of 5730 years) which is highly mobile in the geosphere. The ${ }^{14} \mathrm{C}$ in its present form on the deionizer resins cannot be disposed of at SRS under the present PA-based waste acceptance criteria (WAC).

In 1994, a SRS task team evaluated various disposition options for the reactor deionizers and resins. The preferred option was identified as passive immobilization and is still considered 
to be the most cost-effective means of disposal, requiring no processing of resins themselves, no transfer facilities, no capital expenditures, no specialized monitoring and a safe means of disposal for ${ }^{14} \mathrm{C}$. This option consists of an overpack of calcium oxide that will fix the ${ }^{14} \mathrm{C}$ as calcium carbonate when the stainless steel deionizer vessels fail. Calcium carbonate is only slightly soluble in water. A PA for ${ }^{14} \mathrm{C}$ in this form must be performed to demonstrate that overpack of the resins with calcium oxide will provide a level of chemical stabilization that will assure that this waste form can be disposed of at SRS and that human health and the environment will be protected. There is a concern that the presence of moisture and sulfur oxidizing bacteria in soils at SRS may generate enough sulfuric acid to cause early failure of concrete and carbonate waste forms. The mode of disposal for the moderator deionizers is such that the concrete vaults have to fail before attack on the deionizer overpack begins. The incremental time to failure of the vaults and other concrete forms due to bacterial action would be quantified in the PA evaluation.

The deionizers have been included in the Environmental Management Integration's MLLW/LLW "Waste/Materials Without Disposition (Orphans)" as an opportunity. Evaluations will be conducted DOE complex-wide of treatment and disposal using other DOE sites (such as NTS) or commercial alternatives. If an alternative is identified that seems promising, this PA work may be delayed.

b. Milestone: Issue SA (EAV PA addendum) on EAV disposal of reactor deionizers and resins.

c. Due Date: FY00

\section{d. Responsibility: SWD/SRTC}

e. Estimated Cost: $\$ 30 \mathrm{~K}$.

6. Evaluate Trench Disposal of Vitrified Glass Waste Forms - FY00

a. Description: The M-Area Vitrification Facility has stabilized mixed waste in glass. These glass waste forms will require disposal as LLW if it can be demonstrated that the waste form meets all the hazardous leaching requirements and does not contain listed waste. These waste forms will be evaluated for trench disposal to minimize disposal costs.

b. - Milestone: Issue SA (EAV PA addendum) on trench disposal of glass .waste forms.

c. Due Date: FY00

\section{d. Responsibility: SWD/SRTC/M-Area}

e. Estimated Cost: $\$ 50 \mathrm{~K}$.

7. Evaluate Disposal of Sealed Sources $-{ }^{137} \mathrm{Cs}$ with Lead Shielding - FY00

a. Description: Savannah River Ecology Laboratory (SREL) used a cesium source in their irradiation facility for radiation studies on vegetation and mammals in the 1960s. This cesium source has not been used since 1970 , and with no anticipated use, was declared to be excess material in 1975. In 1981, the source which contained 6350 curies of cesium was moved to the SWDF for interim storage. Interim storage is required for this source which may be reused or declared a waste requiring treatment/disposal at a later date. If the source is declared a waste, one disposition.option requires a PA evaluation for trench disposal. Preliminary studies for shallow-land burial predicted that the cesium would readily dissolve in water as $\mathrm{CsCl}$ but would be tightly bound by the clays located in the burial ground, minimizing anticipated environmental impacts. The PA evaluation will take credit for the 
containment offered by the concrete culverts and the stainless steel capsules holding the cesium as well as inventory reduction by decay.

b. Milestone: Issue SA (EA.V PA addendum) on disposal of ${ }^{137} \mathrm{Cs}$.

c. Due Date: FYOO

d. Responsibility: SWD/SRTC

e. Estimated Cost: $\$ 50 \mathrm{~K}$

8. Develop Closure Plan for E-Area Vaults - FY00.

a. Description: Draft DOE Order 435.1 requires that the EAV disposal site have a closure plan within 1 year from obtaining the Disposal Authorization Statement (DAS). We anticipate receiving the DAS in FY99, and therefore, are planning to complete the closure plan in FY00.

b. 'Milestone: Issue Closure Plan for EAV burial ground.

c. Due Date: FY00 develop plan, FY01 incorporate DOE comments

d. Responsibility: SWD

e. Estimated Cost: FYO0 $\$ 85 \mathrm{~K}$ (develop plan) + FY01 $\$ 45 \mathrm{~K}$ (to incorporate DOE comments)

9. Evaluate Components-in-Grout

a. Description: Provide the Special Analysis (SA) for Components-in-Grout for DOE review and approval to allow large equipment to be disposed in trenches by grouting around or placing components in concrete containers. (This SA will not include an uncertainty evaluation. The nature and extent of an uncertainty evaluation will be resolved during the review of the PA Revision.)

b. Milestone: FY99 Provide Components-in-Grout Special Analysis to DOE FY00 Respond to DOE comments and issue approved SA.

c. Due Date: $9 / 99$ and $1 / 00$

d. Responsibility: SW:D/SRTC

e. Estimated Cost: FY99 $\$ 40 \mathrm{~K}$, FY00 $\$ 40 \mathrm{~K}$

10. Evaluation of Equipment with Lead Shielding/Counterweights

a. Description: Complete Analyses of Equipment With Lead Strielding/Counterweights to obtain approvals from South Carolina Department of Health \& Environmental Control (SCDHEC) and DOE to dispose of this type of waste as LLW.

b. Milestone: FY99 Provide analysis of lead performance as a waste form and limits for disposal to ensure drinking water standards are maintained.

FY00 Assist in application of analysis and development of implementation procedures.

c. Due Date: $9 / 99$ and $9 / 00$

d. Responsibility: SWD, SRTC 


\section{e. Estimated Cost: FY99 25K, FY00 \$25K}

11. Evaluate Disposal of Environmental Restoration (ER). Waste Forms.
a. Description: As new wastes are identified in the ER program, special analyses will be required to determine proper disposal paths.
b. Milestone: Issue SA on ER waste forms as identified.
c. Due Date: FY01-03, FY06
d. Responsibility: SWD, SRTC, ER
e. Estimated Cost: $\$ 40 \mathrm{~K}$ per evaluation to be funded by ER.

12. Evaluate Waste Forms from Mixed Oxide Fuel Facility (MOX), the Pit Disassembly and Conversion Project, and the Pu Immobilization Project
a. Description: Provide for an evaluation of the waste forms to either determine the waste is within the current PA or provide a Special Analysis. (The impact on the CA will be evaluated as a part of this task.)
b. Milestone: Consistent with project schedules: Design 01, construction 02-05, and startup 06
c. Due Date: FY01, FY02; FY03, FY04, FY05, FY06
d. Responsibility: SWD, SRTC, project teams
e. Estimated Cost: $\$ 50 \mathrm{~K}$ per year to be funded by the projects.

13. Evaluate Tritium Extraction Facility (TEF) Waste Form
a. Description: Continue efforts to evaluate the TEF waste form to ensure it meets. the PA or provide a Special analysis, if needed. (The impact on the CA will be evaluated-as a part of this task.)
b. Milestone: Consistent with TEF schedules
c. Due Date: FY00, FY01, FY02
d. Responsibility: SWD, SRTC, TEF
e. Estimated Cost: $\$ F Y 99 \$ 40 \mathrm{~K}$, FY00 $\$ 40 \mathrm{~K}$

14. Evaluate Decontamination \& Decommissioning (D\&D) Waste Forms
a. Description: Provide an evaluation of the $D \& D$ waste forms to either determine the waste is within the current PA or provide a Special Analysis. (The impact on the CA will be evaluated as part of this task.)

b. Milestone: Conșistent with D\&D schedules

c. Due Dáte: FY03 - FY08

d. Responsibility: SWD, SRTC, D\&D 


\section{e. Estimated Cost: $\$ 40 \mathrm{~K}$ per year to be funded by $D \& D$}

15. Special Analyses for Special/Problem Waste Forms

a. Description: Operational facilities will create waste forms that were previously unanalyzed or the current analysis is incomplete. This item allows for completion of the appropriate analyses to ensure compliant disposal. (The impact on the $\mathrm{CA}$ will be evaluated as part of this task.

b. Milestone: N/A

c. Due Date: FY02-FY08

d. Responsibility: SWD, SRTC

e. Estimated Cost: $\$ 50 \mathrm{~K}$ per year

\section{B. CA Special Analyses}

Special analyses will be required based on the following:

- Any changes in land use plans or remediation or closure plans of any of the facilities considered in the $\mathrm{CA}$,

- To upgrade the existing $C A$ analyses (e.g., incorporate $R \& D$ results),

- To evaluate the impact of PA special analyses on the results of the CA. Therefore, as part of each of the PA special analyses, an evaluation will be included to assess the impact on the CA.

1. Evaluate Alternative Trench.Disposal Concepts

a. Description: A team of Solid. Waste Division and SRTC PA experts is planned to determine the best way to implement trench disposal of large equipment (in grout), compacted job control waste, non-compactable, and non-incinerable waste. (See A.1.a.)

b. Milestone: Issue an evaluation on the impact to the $\mathrm{CA}$ results as a section of the PA special analysis.

c. Due Date: $9 / 00$.

d. Responsibility: SRTC

e. Estimated Cost: $\$ 0$ (included in FY1999 budget for PA Maintenance).

2. Evaluate Disposal of Waste Containing ${ }^{129} \mathrm{I}$

a. Description: ETF has determined that activated carbon filter columns prepared for disposal in the E-Area LLW Disposal facilities contain high ${ }^{129}$ I concentrations. These columns contain

${ }^{129}$ I concentrations that exceed PA Inventory Limits. Funding is provided in FY99 for Savannah River Technology Center to review PA credit options for the high ${ }^{129}$ I concentration in the columns.

Environmental Restoration (ER) has solidified basin sludge from their Groundwater Remediation Project that contains ${ }^{129} I$ concentrations that are higher than the LAW Vault WAC concentration limit as well. This administrative limit was established by the PA inventory requirements for ${ }^{129} \mathrm{I}$ in the LAW Vault. Funding is provided in FY99 for SRTC to review PA credit options for the high ${ }^{129} \mathrm{I}$ concentration in the sludge. The impact to the results of the $C A$ will be evaluated in this PA special analysis. 
b. Milestone: Issue the evaluation on the impact to the $\mathrm{CA}$ results as a section of the PA special analysis.

c. Due Date: $6 / 30 / 99$

d. Responsibility: SRTC

e. Estimated Cost: $\$ 0$ (included in FY1999 budget for PA Maintenance).

3. Evaluate Trench Disposal of Vitrified Glass Waste Forms

a. Description: The M-Area Vitrification Facility has stabilized mixed waste in vitrified glass forms. These glass waste forms will require disposal as LLW if it can be demonstrated that the waste form meets all the hazardous leaching requirements and does not contain listed waste. These waste forms will be evaluated for trench disposal to minimize disposal costs. The impact to the results of the CA will be evaluated in this PA special analysis.

b. Milestone: Issue the evaluation on the impact to the $\mathrm{CA}$ results as a section of the PA special analysis.

c. Due Date: FY00

d. Responsibility: SRTC

e. Estimated Cost: $\$ 0$ (planned for inclusion in FY2000 budget for PA Maintenance).

4. Evaluate Disposal of Sealed ${ }^{137} \mathrm{Cs}$ Sources

a. Description: Savannah River Ecology Laboratory (SREL) used a large cesium source in their irradiation facility for radiation studies on vegetation and mammals in the 1960s. In 1981, the source which contained 6350 curies of cesium was moved to the Solid Waste Disposal Facility (SWDF) for interim storage. If the source is declared a waste, one disposition option requires a PA evaluation for trench disposal. Preliminary studies for shallow-land burial predicted that the cesium would readily dissolve in water as $\mathrm{CsCl}$ but would be tightly, bound by the clays located in the Burial Ground, minimizing anticipated environmental impacts. The PA evaluation will take credit for the containment offered by concrete culverts and the stainless steel capsules holding the cesium as well as inventory reduction by decay. The impact to the results of the CA will be evaluated in this PA special analysis.

b. Milestone: Issue the evaluation on the impact to the CA results as a section of the PA special analysis.

c. Due Date: FY00

d. Responsibility: SRTC

e. Estimated Cost: $\$ 0$ (planned for inclusion in the FY2000 budget for PA Maintenance).

5. Evaluate changes to Saltstone Process that may result from alternate processes for salt decontamination (in place of In-Tank Precipitation).

a. Description: In FY98 DOE decided to cease work on implementing the In-Tank Precipitation (TTP) process for decontaminating the low-level salt waste resulting from preparing high-level waste for vitrification. Following this decision, an intensive process was conducted to determine options for improved salt decontamination: A few candidate processes were 
selected for detailed evaluation. Each of these processes will result in salt solution feed to the Saltstone process that has different characteristics than the feed evaluated in the Saltstone PA. and in the CA. Thus, the impacts of the different feed in each of the candidate processes on the Saltstone PA will be evaluated as part of the maintenance of the Saltstone PA. The impacts of these changes on the $C A$ will be evaluated under the CA maintenance plan.

b. Milestone: Issue reports on these evaluations. The reports may take the form of WSRC technical reports or PA Special Analyses, as appropriate.

c. Due Date: Contingent on DOE-SR direction

d. Responsibility: SRTC

e. Estimated Cost: $\$ 0$ (will be included in the budget for PA Maintenance.)

6. Evaluate the Components-in-Grout SA and issue an evaluation on the impact to the CA results.

\section{Saltstone PA Special Analyses}

1. Evaluate changes to Saltstone Process that may result from alternate processes for salt decontamination (in place of In-Tank Precipitation).

a. Description: In FY98 DOE decided to cease work on implementing the In-Tank Precipitation (ITP) process for decontaminating the high-level salt waste in preparation for high-level waste vitrification. Following this decision, an intensive procęss was conducted to determine options for improved salt decontamination. A few candidate processes were selected for detailed evaluation. Each of these processes will result in decontaminated salt solution feed to the Saltstone process for treatment and disposal as low-level waste that has different characteristics than the feed evaluated in the Saltstone PA and in the CA. Thus, the impacts of the different feed in each of the candidate processes on the Saltstone PA will be evaluated as part of the maintenance of the Saltstone PA.

b. Milestone: Issue reports on these evaluations. The reports may take the form of WSRC technical reports or PA Special Analyses, as appropriate.

c. Due Date: Contingent on DOE-SR direction. For budgeting purposes, will assume that analysis is completed in FYOO.

d. Responsibility: SWD/SRTC

e. Estimated Cost: $\$ 50 \mathrm{~K}$

2. Revise Closure Plan for Saltstone - FY00

a. Description: Draft DOE Order 435.1 requires that the Saltstone disposal vaults have a closure plan within 1 year from obtaining the DAS. We anticipate receiving the DAS in FY99, and therefore, are planning to revise the existing closure plan in FY0O.

b. Milestone: Issue Closure Plan for Saltstone disposal vaults.

c. Due Date: FYOO

d. Responsibility: SWD/HLW

e. Estimated Cost: $\$ 60 \mathrm{~K}$ (develop plan and incorporate DOE comments) 


\section{PA/CA REVISIONS}

\section{A. EAY PA Revision}

1. Incorporate DOE Comments - FY99

a. Description: A complete revision of the EAV PA was completed in FY98. During FY99, DOE-SR comments and concerns will be evaluated and resolved as necessary. This will include any additional modeling and changing report, as necessary. The EAV PA revision will be ready for submission to DOE-HQ within six months after DOE-SR provides comments. After submission of the PA revision to DOE-HQ, this task will include support of the DOE-HQ Low-Level Waste.Federal Review Group's (LFRG) comments and those of the review team.

b. Milestone: Incorporate DOE comments to PA revision.

c. Due Date: 6 months after DOE-SR issuance of comments. (FY99/00)

Respond to DOE-HQ (LFRG) Review for Approval: FY00

d. Responsibility: SWD/SRTC

e. Estimated Cost: $\$ 140 \mathrm{~K}$ FY99

$\$ 150 \mathrm{~K}$ FY00

2. Complete Draft PA Revision - Outyears (FY04)

a. Description: A complete revision of the EAV PA will be scheduled as required and as agreed upon by DOE. The EAV PA will be revised when warranted, but for budgeting purposes will be scheduled for FY04. The revised PA will include the following items at a minimum:

- All special analyses (i.e., EAV addenda) that have been completed to date .

- Changes in site future land use plans or closure plans

- Changes to PA guidance documents requirements

b. Milestone: Issue draft PA revision

c. Due Date: Outyears (FY04)

d. Responsibility: SWD/SRTC

e. Estimated Cost: $\$ 750 \mathrm{~K}$

\section{B. CA Revision}

Per Draft DOE 435.1, CA revisions are required when changes in sources analyzed, land-use plans, or understanding of the site environment (e.g., significant changes that alter the basis for the conceptual model) alter the conclusions of the $\mathrm{CA}$. The form of the $\mathrm{CA}$ revision can range from a simple amendment to the $\mathrm{CA}$ to a reissuance of the $\mathrm{CA}$ document.

1. Respond to DOE Conditional Approval of the CA

a. Description: A written response to each of the DOE's "Conditions of Approval" (CoA) will be completed and issued as an addendum to the CA. The CoA are listed in Table 2. 


\section{Table 2: Conditions of Approval}

\begin{tabular}{|c|c|}
\hline 1 & $\begin{array}{l}\text { Point of Assessment/Pathways - Based on approved Land Use Plan and as a first step in } \\
\text { a more comprehensive analysis, issue an addendum to the CA to reflect a single point of } \\
\text { compliance at the confluence of Upper Three Runs (UTR) with the Savannah River } \\
\text { using the recreational scenario currently in the CA. }\end{array}$ \\
\hline 2 & $\begin{array}{l}\text { Uncertainty and Sensitivity Analysis - Perform a sensitivity analysis on the } \\
\text { radionuclides important to the composite analysis and flux rates and on the hydrologic } \\
\text { model including the groundwater divide and the model boundary conditions. Perform } \\
\text { an Uncertainty Analysis on the inventory, flux rates, and resultant dose calculations for } \\
\text { the radionuclides important to the CA. }\end{array}$ \\
\hline 3 & $\begin{array}{l}\text { Source Term/Inventory - Provide a complete source term for the CA to include a } \\
\text { complete inventory of the UTR watershed and a reanalysis of the source term that was } \\
\text { arbitrarily assigned to Cs and Sr to provide a more realistic radionuclide distribution. }\end{array}$ \\
\hline 4 & $\begin{array}{l}\text { Include in the addendum to the } C A \text { the assumptions and justification for the } \\
\text { assumptions used in the analysis. }\end{array}$ \\
\hline 5 & Disposition of all composite analysis review team comments. \\
\hline 6 & $\begin{array}{l}\text { Discussion of the environmental monitoring program, inclusion of environmental } \\
\text { monitoring data, and comparison with the expected results from the composite analysis. }\end{array}$ \\
\hline 7 & $\begin{array}{l}\text { Inclusion of the information that SRS committed to be incorporated in the CA } \\
\text { maintenance plan over the course of the CA review. } \\
\text { The CA MAP addresses "inclusion of the information that Savannah River Site } \\
\text { committed to be incorporated in the composite analysis maintenance plan over the } \\
\text { course of the Composite Analysis Review." These commitments are reflected in the } \\
\text { minutes of the review team meetings and are consolidated in Table 3. Table } 3 \\
\text { commitments are all covered either in items \#1-6 in Table } 2 \text { or are addressed in other } \\
\text { areas of the CA MAP (e.g., CA Special Analyses). }\end{array}$ \\
\hline
\end{tabular}


Table 3: SRS Commitments during CA Review (CoA\#7)

\begin{tabular}{|c|c|}
\hline Reterenge & 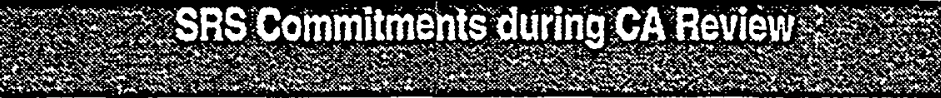 \\
\hline $\begin{array}{l}\text { March 10-12, } \\
1998 \text { Meeting }\end{array}$ & $\begin{array}{l}\text { a. Modify CA based on changes in plans or actions for } \\
\text { CERCLA. } \\
\text { b. Discuss CA MAP with CA Review Team. } \\
\text { c. List the CA conclusions that need more basis and modify the } \\
\text { CA to include expanded discussion on these identified CA } \\
\text { conclusions. } \\
\text { d. Modify CA to address the dose contribution from the entire } \\
\text { site radionuclide inventory. }\end{array}$ \\
\hline $\begin{array}{l}\text { May 27-28, } \\
1998 \text { Meeting }\end{array}$ & No commitments were made. \\
\hline $\begin{array}{l}\text { July 23-24, } \\
1998 \text { Meeting }\end{array}$ & $\begin{array}{l}\text { e. Identify deficiencies in the CA and modify CA to remove } \\
\text { deficiencies. } \\
\text { f. Identify additional information needed in the } C A \text { and modify } \\
\text { accordingly. Determine how to address conditions to gather } \\
\text { the needed information. }\end{array}$ \\
\hline
\end{tabular}

b. Milestone: Issue the response to the Conditions of Approval and other actions listed in Table 2 and Table 3 as an addendum to the $\mathrm{CA}$.

c. Due Date: The CA addendum will be issued by 9/23/99 and will include CoA \#1-7 as listed in Table 2 and items a. - f. as listed in Table 3.

d. Responsibility: SWD/SRTC

e. Estimated Cost: $\$ 140 \mathrm{~K}$

\section{Saltstone PA Revision}

1. Complete Draft Saltstone PA Revision - Outyears (FY05)

a. Description: A complete revision of the Saltstone PA will be scheduled as required and as agreed upon by DOE. The Saltstone PA will be revised when warranted, but for budgeting purposes will be scheduled for FY05. The revised PA will include the following items at a minimum:

- All special analyses (i.e., Saltstone PA addenda) that have been completed to date

- Changes in site future land use plans or closure plans

- Changes to PA guidance documents requirements

b. Milestone: Issue draft PA revision.

c. Due Date: Outyears (FY05)

d. Responsibility: SWD/SRTC

e. Estimated Cost: $\$ 300 \mathrm{~K}$ 


\section{Saltstone PA Conditional Acceptance}

a. Description: The Saltstone PA was conditionally approved on February 18,1998 by DOE-HQ. As a resolution to the item to address uncertainties of the performance of a degraded system, the plan is to provide the requested analysis when evaluating the replacement to ITP (see section C.1.a.). When requested to evaluate the replacement waste form, we will include addressing the uncertainties of a degraded system. The ITP replacement effort is expected to fund the PA work related to a modified waste form. The cost to perform a Special Analysis including the uncertainty work will be approximately $\$ 100 \mathrm{~K}$. If a completely new waste form is selected, a major revision to the PA is required. The cost is expected to be about $\$ 750 \mathrm{~K}$.

In summary, the conditions for acceptance were as follows:

1. Provide ALARA analysis commensurate with calculated doses.

2. Provide an addendum to the RPA to include additional information assembled subsequent to submittal of the RPA.

3. Develop a plan committing to a budget and schedule to address uncertainties of the performance of a degraded system.

4. Submit analysis of design changes to the disposal facility to EM-30 for review and acceptance prior to construction.

5. Maintain the RPA in accordance with 1996 Department of Energy Low Level Waste Performance Assessment Maintenance Guidance.

Items 1, 2, and 4 were provided to DOE-HQ on July 1, 1998 (Schepens to Frei). Items 3 and 5 are provided by submittal of this PA Maintenance Plan.

\section{ANNUAL REVIEWS}

\section{A. EAV PA Annual Review}

PA reviews have been conducted annually since FY98. The PA- review will be conducted in a systematic manner that incorporates all of the following considerations:

1) Radionuclide Inventories, Waste Volumes, and Waste Types - The review of waste radionuclide inventories and waste volumes will include a comparison of the actual waste receipt to that projected in the PA. Future waste receipts as estimated in the waste forecast report will also be considered.

2) Past and Future Events - The "past" events are primarily documented in special analyses addenda: The review will also consider expected future events in terms of their significance to disposal operations and the adequacy of the PA in representing facility performance relative to performance objectives.

3) Results of Monitoring and Research \& Development - Currently, there are technological limitations on the monitoring that can be performed for the purpose of confirming (1) that the EAV is performing as postulated in the PA and (2) that the conceptual models are still applicable. Development activities are planned as part of the Test, Research, and Monitoring Program described in Sections IV and $V$ of this report.

4) Other Relevant Factors - Other operational and design considerations that may be relevant to the review of the PA are listed in the draft DOE Order 435.1 guidance. Specific operation or design features that were not discussed in the previous sections are disposal geometry, waste packaging, WAC, Waste Information Tracking System, provisions for performance monitoring, structural stability and other design features, and the future land use plans. 
All of these factors will be reviewed annually to evaluate the need to conduct special studies or to prepare a revision of the PA. A report will be.generated each year documenting the results of the study. The annual cost is an estimated $\$ 30 \mathrm{~K}$.

\section{B. CA Annual Review}

CA reviews will be conducted annually, beginning in FY00. The CA review approach will be conducted in a systematic manner that incorporates all of the following considerations:

1) Site Future Land Use Plans - These plans will be reviewed in regards to the impact of any changes on the CA results and conclusions.

2) PA analyses - All PA analyses will be reviewed and the impact on the CA results will be addressed. This is reflected in Section I, Special Analyses.

3) Changes in remediation or closure plans - The review will consider changes in remediation or closure plans for any of the facilities considered in the $\mathrm{CA}$ and the impact that those changes will have on the $C A$ results.

4) Changes in inventory estimates - The review will consider changes in the inventory estimates considered in the CA to determine the impact.

5) Results of monitoring and R\&D.

All of these factors will be reviewed annually to evaluate the need to conduct special studies or to prepare a revision of the $\mathrm{CA}$. A report will be generated each year documenting the results of the study. The annual cost is an estimated $\$ 50 \mathrm{~K}$.

\section{Saltstone PA Annual Review}

The Saltstone PA annual review will be conducted in the same systematic manner as the EAV PA as described in Section III.A. Saltstone PA annual reviews will be budgeted annually beginning in FY99. The first review was completed 5/11/99.

As discussed in Section C.1.a., in FY98 DOE ceased work on the ITP process to prepare feed to the Saltstone facility. As a result, Saltstone is not operational and is not expected to operate until a decision is made regarding ITP. Therefore, it is recommended that after the FY99 Annual Review, additional annual reviews should not be conducted until a decision regarding ITP and the future of the Saltstone facility is determined. The LLW disposed will be evaluated in the FY99 Annual Review.

\section{MONITORING}

\section{A. EAV PA Monitoring}

Table 4 lists the planned monitoring activities for the EAV which will be reflected in the Ten Year Plan and the Annual Operating Plan for the appropriate years. These activities are reflected in the " $E$ Area Monitoring Program for the E-Area Low-Level Radioactive Waste Disposal Facility" (SWDSWE-98-0153) which was developed in FY98. The monitoring activities being completed in FY99 have specific tasks required of different departments as shown in Table 5. 
Table 4. Implementation Strategy for the EMOP

\begin{tabular}{|c|c|c|c|c|c|c|}
\hline IA & $\begin{array}{l}\text { Existing } \\
\text { Trenches }\end{array}$ & None & $\begin{array}{l}\text { Install VZMS } \\
\text { (3 VZMS } \\
\text { wells) }\end{array}$ & $\begin{array}{l}\text { VZMS offers the only solution to both of the stated } \\
\text { needs/objectives: verification of DOE order } \\
\text { compliance and PA validation. }\end{array}$ & 1999 & $\$ 352 \mathrm{~K}$ \\
\hline IB & $\begin{array}{l}\text { Existing } \\
\text { Trenches }\end{array}$ & None & $\begin{array}{l}\text { Install VZMS } \\
(9 \text { VZMS } \\
\text { wells) }\end{array}$ & $\begin{array}{l}\text { Meets the same objectives as Phase IA. (Two } \\
\text { subphases allows "lessons learned" from Phase IA } \\
\text { to be applied in Phase IB.) }\end{array}$ & 2000 & $\$ 393 \mathrm{~K}$ \\
\hline II & $\begin{array}{l}\text { LAW Vaults, IL } \\
\text { Vaults } \\
\text { New Trenches } \\
\text { (existing site) }\end{array}$ & $\begin{array}{l}\text { Vault Sump } \\
\text { Monitoring }\end{array}$ & $\begin{array}{l}\text { Continue Vault } \\
\text { Sump } \\
\text { Monitoring } \\
\text { Install VZMS }\end{array}$ & $\begin{array}{l}\text { Provides early-waming. } \\
\text { VZMS offers the only solution to both of the stated } \\
\text { needs/objectives. }\end{array}$ & 2000 & $\$ 966 \mathrm{~K}$ \\
\hline III** & $\begin{array}{l}\text { Future Trenches } \\
\text { (relocated site) }\end{array}$ & $\begin{array}{l}\text { Site } \\
\text { Monitoring } \\
\text { Program }\end{array}$ & $\begin{array}{l}\text { Continue Site } \\
\text { Ground-water } \\
\text { Monitoring } \\
\\
\text { Install VZMS }\end{array}$ & $\begin{array}{l}\text { Proposed location is upgradient of the existing } \\
\text { tritium plume, enabling groundwater monitoring to } \\
\text { meet both of the stated needs/objectives. Also, there } \\
\text { is a confining unit (i.e., a clay layer) in the South } \\
\text { EADF that separates the deeper aquifers, which are } \\
\text { more likely to be contaminated with tritium from } \\
\text { previous disposal operations. Groundwater } \\
\text { monitoring will offer only direct monitoring method } \\
\text { to verify compliance with DWS once contaminants } \\
\text { reach the water table. } \\
\text { Enables PA validation in vadose zone (i.e., above } \\
\text { water table). }\end{array}$ & 2001 & $\$ 745 \mathrm{~K}$ \\
\hline IV** & $\begin{array}{l}\text { Future Trenches } \\
\text { (relocated site) }\end{array}$ & $\begin{array}{l}\text { Site } \\
\text { Monitoring } \\
\text { Program }\end{array}$ & $\begin{array}{l}\text { Install ground- } \\
\text { water wells } \\
\text { within E-Area } \\
\text { boundary }\end{array}$ & $\begin{array}{l}\text { Additional shallow groundwater wells within } \\
\text { boundary enhances adequacy of groundwater } \\
\text { monitoring program. }\end{array}$ & 2002 & $\$ 362 \mathrm{~K}$ \\
\hline
\end{tabular}

* Monitoring activities are included only if they provide any benefit.

$\therefore$ " $\because ; \quad ;$

:

** Phase III and IV costs do not include moving the TRU pad and other associated tasks, if required. It is unlikely movement of the TRU pad and planned storage areas will be required since sufficient area for trench installation is available in the South EADF.

Table 5: FY99 EAV Vadose Zone Monitoring Tasks

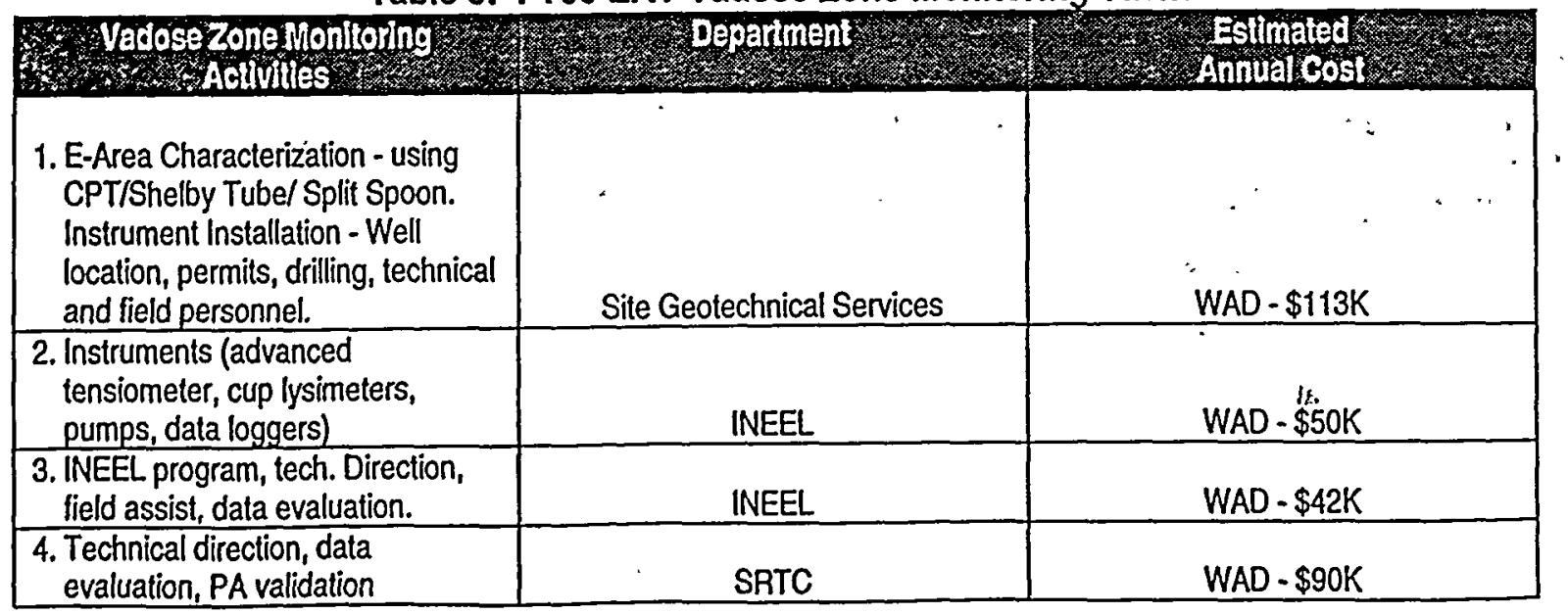




\section{B. CA Monitoring}

Monitoring is considered the primary means to validate the $\mathrm{CA}$. The existing Site Mónitoring Program (SMP) well and stream monitoring data will be utilized, where possible, in CA validation. One of the first tasks to be completed under the monitoring element of the CA MAP is to develop the protocol that will be utilized to validate the $\mathrm{CA}$. Current well and stream sampling locations will be evaluated to ensure that data can be used to validate the CA results. This task initiative will be conducted in FY00 as described below.

1. Develop Protocol for CA Validation

a. Description: This task involves the evaluation of current well and stream sampling locations to determine if additional sampling points are required. Once the protocol is developed, accurate comparison of SMP well and stream data with CA results can be conducted. This task will also include an initial comparison of existing monitoring data with $\mathrm{CA}$ results.

b. Milestone: Issue report that describes the protocol to validate the $\mathrm{CA}$ that includes initial comparison of existing monitoring data with $\mathrm{CA}$ results.

c. Due Date: FY00

d. Responsibility: SRTC

e. Estimated Cost: $\$ 30 \mathrm{~K}$

2. Conduct Annual CA Validation

a. Description: This task involves comparison of SMP well data with CA results and will be conducted on an annual basis.

b. Milestone: Issue $\mathrm{CA}$ validation report that describes comparison of well data with $\mathrm{CA}$ results.

c. Due Date: FY01 through outyears. '?

d. Responsibility: SWD/SRTC

e. Estimated Cost: $\$ 10 \mathrm{~K} / \mathrm{year}$

\section{Saltstone PA Monitoring}

Monitoring is considered the primary means to validate the Saltstone PA. The SMP well data will be utilized in the Saltstone PA validation. One of the first tasks to be completed under the monitoring element of the Saltstone PA MAP is to develop the protocol that will be utilized to validate the Saltstone PA. Current well locations will be evaluated to ensure that data can be used to validate the Saltstone PA results. This task initiative will be conducted in FYO0 as described below.

\section{Develop Protocol for Saltstone PA Validation}

a. Description: This task involves the evaluation of current well locations to determine if additional sampling points and increased sampling frequencies are required. Once the protocol is developed, accurate comparison of SMP well data with Saltstone PA results can be conducted. This task will also include an initial comparison of existing monitoring data with Saltstone PA results.

b. Milestone: Issue report that describes the protocol to validate the Saltstone PA that includes initial comparison of existing monitoring data with Saltstone PA results. 

c. Due Date: FY00
d. Responsibility: SWD/SRTC
e. Estimated Cost: $\$ 40 \mathrm{~K}$

2. Conduct Annual Saltstone PA Validation
a. Description: This task involves comparison of SMP well data with Saltstone PA results and will be conducted on an annual basis.
b. Milestone: Issue Saltstone PA validation report that describes comparison of well data with PA results.
c. Due Date: FY01 through outyears.
d. Responsibility: SWD/SRTC
e. Estimated Cost: $\$ 10 \mathrm{~K} / \mathrm{year}$

\section{TEST AND RESEARCH ACTIVITIES}

\section{A. EAY PA Test \& Research Activities}

Table 6 lists the planned test and research activities that will be reflected in the Ten Year Plan and the Annual Operating Plan for the appropriate years. These activities were determined from three primary sources: (1) DOE Orders, (2) EAV PA Recommendations \& Critical Assumptions, and (3) DOE Complex Wide Needs Statement (Reference). 
Table 6: PA MAP Test \& Research Activities

\begin{tabular}{|c|c|c|c|}
\hline & (5) & & $\cos$ \\
\hline 1 & $\begin{array}{l}\text { Qualify and Expand PATHRAE/ Compare GW Modeling Codes } \\
\text { FY98 activities to modify PATHRAE code to include simplified diffusional releases that } \\
\text { simulate the release from cement waste forms are complete. In FY99, PATHRAE modeling } \\
\text { results (after expanding code for considering diffusional relecases) will be compared to } \\
\text { PORFLOW code PA results. If successful, this will allow use of simpler, less costly analytical } \\
\text { codes in conducting special analyses for PA changes rather than using the more difficult codes } \\
\text { such as PORFLOW. This would translate into substantial savings on selected modeling } \\
\text { exercises. }\end{array}$ & FYOO & $\$ 100 \mathrm{~K}$ \\
\hline 2 & $\begin{array}{l}\text { Obtain Kd Data for Organic Materials } \\
\text { Conduct lab experiments to obtain Kd data for organic materials. Data will refine or validate } \\
\text { PA input data/assumptions/results. }\end{array}$ & $\begin{array}{l}\text { Com- } \\
\text { plete }\end{array}$ & $\mathrm{NA}$ \\
\hline 3 & $\begin{array}{l}\text { Develop Experimental Capability to Obtain Kd Data } \\
\text { In groundwater modeling, Kd determines contaminant transport rate through the environment. } \\
\text { Kd values which have been used, conservatively, as a constant in the EAV models were } \\
\text { obtained from literature. More realistically, the Kd values should vary as a function of } \\
\text { parameters such as pH of soils, contaminant chemical form, and temperature. Site specific Kd } \\
\text { values for selected radionuclides need to be confirmed through laboratory testing. Task will } \\
\text { include development of lab protocol to obtain Kd data. Also, need to identify lab resources, } \\
\text { survey literature and contact researchers at National Labs, and design experiments. Data may } \\
\text { be collected on several radionuclides of interest each year. The PA will be reviewed to confirm } \\
\text { key radionuclides each year prior to testing. SRT-WED-97-0173, Rev.l, Table I includes the } \\
\text { ten most limiting radionuclides in the EAV vaults whose estimated inventory is closest to the } \\
\text { most restrictive limit. This table will be a basis for the selection of key radionuclides. }\end{array}$ & $\begin{array}{l}\text { FY00- } \\
\text { FY08 }\end{array}$ & $\begin{array}{l}\text { FY00: } \\
\$ 130 \mathrm{~K} \\
\text { FY01- } \\
\text { FY08: } \\
\$ 50 \mathrm{~K} / \mathrm{yr} .\end{array}$ \\
\hline 4 & $\begin{array}{l}\text { Benchmark PORFLOW vs. BLT-EC } \\
\text { The BLT-EC code is able to account for the effects of geocherwistry on the distribution of } \\
\text { contaminants between the soil and groundwater, resulting in more accurate Kds. The BLT-EC } \\
\text { code is developed and has incorporated specific geochemistry data (and will therefore, result in } \\
\text { more accurate and site-specific Kds.) Task will subbontract BLT-EC code development, } \\
\text { qualificution and benchmaking runs. Successful development will result in ability to evaluate } \\
\text { geochemical interactions and more accurately predict behavior of contaminants in the } \\
\text { environment. }\end{array}$ & FYOO & $\$ 100 \mathrm{~K}$ \\
\hline 5 & $\begin{array}{l}\text { Model Waste as Series of Stirred Tanks } \\
\text { Improve conceptual model, reduce conservatism, and raise limits. }\end{array}$ & FY05 & $\$ 50 \mathrm{~K}$ \\
\hline 6 & $\begin{array}{l}\text { Model Cracks/Vault Collapse } \\
\text { Improve conceptual model, reduce conservatism, and raise limits. }\end{array}$ & FY02 & $\$ 100 \mathrm{~K}$ \\
\hline 7 & $\begin{array}{l}\text { Model Sum-of-Fractions Using Timing of Doses } \\
\text { This modeling change will introduce more vigor by taking advantage of the different "peak } \\
\text { times" for the radionuclides of most impact. This will reduce model conservatism and raise } \\
\text { limits. }\end{array}$ & FYOO & $\$ 50 \mathrm{~K}$ \\
\hline 8 & $\begin{array}{l}\text { Radon Dose Calculations } \\
\text { Uncertainties exist in radon dose calculations and dose effects. Proposed timing will allow for } \\
\text { cstablishment of radon performance objective guidance and dose calculation methodology. }\end{array}$ & FY04 & $\$ 50 \mathrm{~K}$ \\
\hline 9 & $\begin{array}{l}\text { Model Moisture Flow in Vadose Zone } \\
\text { Improved modeling methodology will more accurately model moisture flow and contaminant } \\
\text { transport. }\end{array}$ & FYO5 & $\$ 100 \mathrm{~K}$ \\
\hline 10 & $\begin{array}{l}\text { Improve Computer Model; Techniques to Integrate Boundary Conditions } \\
\text { Improved modeling methodology will more accurately model contaminant transport. }\end{array}$ & $\begin{array}{l}\text { FY00- } \\
\text { FY07 }\end{array}$ & $\$ 50 \mathrm{~K} / \mathrm{yr}$. \\
\hline
\end{tabular}




\begin{tabular}{|l|l|l|l|}
\hline 11 & $\begin{array}{l}\text { Determine Wood Degradation Products } \\
\text { This task is a continuation of Task \#2 that was completed in FY98. Characterization of wood } \\
\text { degradation products under site conditions would refine or validate use of surrogate chemical } \\
\text { compounds used in Wood PA analysis. }\end{array}$ & FY99 & $\$ 60 \mathrm{~K}$ \\
\hline 12 & $\begin{array}{l}\text { Develop Instrumentation to Measure C-14, Tc-99 } \\
\text { Instruments need to be developed to measure important high-impact PA radionuclides. }\end{array}$ & $\begin{array}{l}\text { FY06 - } \\
\text { FY07 }\end{array}$ & $\$ 200 \mathrm{~K} / \mathrm{yr}$. \\
\hline 13 & $\begin{array}{l}\text { Correlate Permeability and Leachability for CIF Ashcrete/Blowcrete } \\
\text { This is a new activity not included in the FY98 PA MAP (Reference 2). However, it is a } \\
\text { technical need required prior to disposal. }\end{array}$ & FY99 & $\$ 50 \mathrm{~K}$ \\
\hline 14 & $\begin{array}{l}\text { Evaluate effect on grout structures/fills on colloid formation and facilitated } \\
\text { transport of contaminants (follow for cellulose degradation study - applied } \\
\text { to vaults). }\end{array}$ & $\begin{array}{l}\text { FY00- } \\
01\end{array}$ & $\begin{array}{l}\$ 25 \mathrm{~K}(00) \\
\$ 20 \mathrm{~K}(01)\end{array}$ \\
\hline
\end{tabular}

\section{B. CA Test \& Research Activities}

The test \& research (T\&R) activities that support the EAV PA have significant commonality with those activities that support the CA. Therefore, those activities listed in Table 6 are also applicable in validation of the CA. The specific CA T\&R activities described in this section focus on studies that will provide data to support more realistic methods to estimate the dose from the four major contributors: ${ }^{3} \mathrm{H},{ }^{14} \mathrm{C}$, ${ }^{237} \mathrm{~Np}$, and isotopes of uranium. The T\&R activities will both improve the understanding of the migration of the major $\mathrm{CA}$ dose contributors, as well as reduce the uncertainty by developing more realistic modeling scenarios. Since the ${ }^{14} \mathrm{C}$ contribution to the dose is two orders of magnitude higher than any other radionuclide, near-term efforts will focus on understanding the release mechanisms of ${ }^{14} \mathrm{C}$. Studies will focus on how the $\mathrm{CA}$ results were obtained, where the uncertainty lies, and how this uncertainty can be reduced. Most of the studies listed below focus on development of more realistic release scenarios and reduction of uncertainty.

1. Study to Reduce Uncertainty in C-14 Dose Contribution

a. Description: This task will involve a study that evaluates the significant elements that contributed to the ${ }^{14} \mathrm{C}$ dose, where the uncertainty lies in the methodology used to obtain the results, and how can the uncertainty be reduced. This study will include an evaluation to determine if more realistic scenarios that contribute to the dose are possible. This study focuses on ${ }^{14} \mathrm{C}$ (as opposed ${ }^{3} \mathrm{H},{ }^{237} \mathrm{~Np}$, and isotopes of uranium) since it was the greatest contributor to the dose and will re-evaluate the release scenarios, stainless steel corrosion rates, resin Kds, and other factors that affect the release of ${ }^{14} \mathrm{C}$.

b. Milestone: Issue report that documents the study to reduce uncertainty in the ${ }^{14} \mathrm{C}$ dose contribution.

c. Due Date: FY2001

d. Responsibility: SRTC

e. Estimated Cost: $\$ 50 \mathrm{~K}$

2. Study to Consider Closure Caps to Reduce Conservatism in Calculated Dose

a. Description: The CA was conservative in the respect that the model did not consider a closure cap for a number of facilities. This task will involve a study that more realistically models the release scenarios to reduce the conservatism by considering closure caps for the Old Burial Ground facilities, the Mixed Waste Management Facility, and other facilities that did not consider a closure cap. 
b. Milestone: Issue report that considers closure caps to reduce conservatism.

c. Due Date: FY2002

d. Responsibility: SRTC

e. Estimated Cost: $\$ 50 \mathrm{~K}$

\section{Saltstone PA Test \& Research Activities}

The T\&R activities that support the EAV PA have significant commonality with those activities that support the Saltstone PA. Therefore, those activities listed in Table 6 are also applicable in validation of the Saltstone PA. There are no additional T\&R activities described in this section that focus on studies that will validate the Saltstone PA. 
Attachment 2

Savannah River Site Future Use Plan 
THIS PAGE INTENTIONALLY LEFT BLANK 
DATE: TAR 13208

R! LYTO

ATTN OF: AMSTBD (Borup/803-725-1579)

zJECT: - Savannah River Site (SRS) Future Use Plan

To: James M. Owendoff, Acting Assistant Secretary for

Environmental Management EM-1, (HQ) .

As mandated by the National Defense Authorization Act for Fiscal Year 1997 and the DOE Strategic Plan, I am pleased to provide the attached SRS Future Use Plan.

The Future Use. Plan was developed in partnership with all major site contractors, support agencies; and Headquarters counterparts with the input of our stakeholders. This plan provides the framework to assure the Site's continued viability in support of vital DOE missions, while preserving its bountiful natural resources.

If you or your staff have any questions regarding the Future Use Plan, please contact me at (803) 725-2405 or Judy Bostock of my staff at (803) 725-3821.

AMSTBD:JS:tda

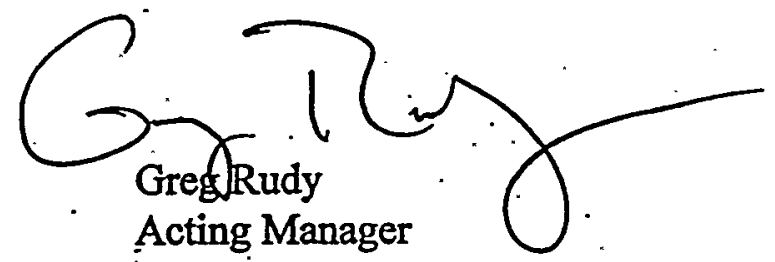

QC-98-005

Attachment

cc w/attch:

J. Werner, DOE (EM-24)

S. Livingstone, DOE (EM-24) 



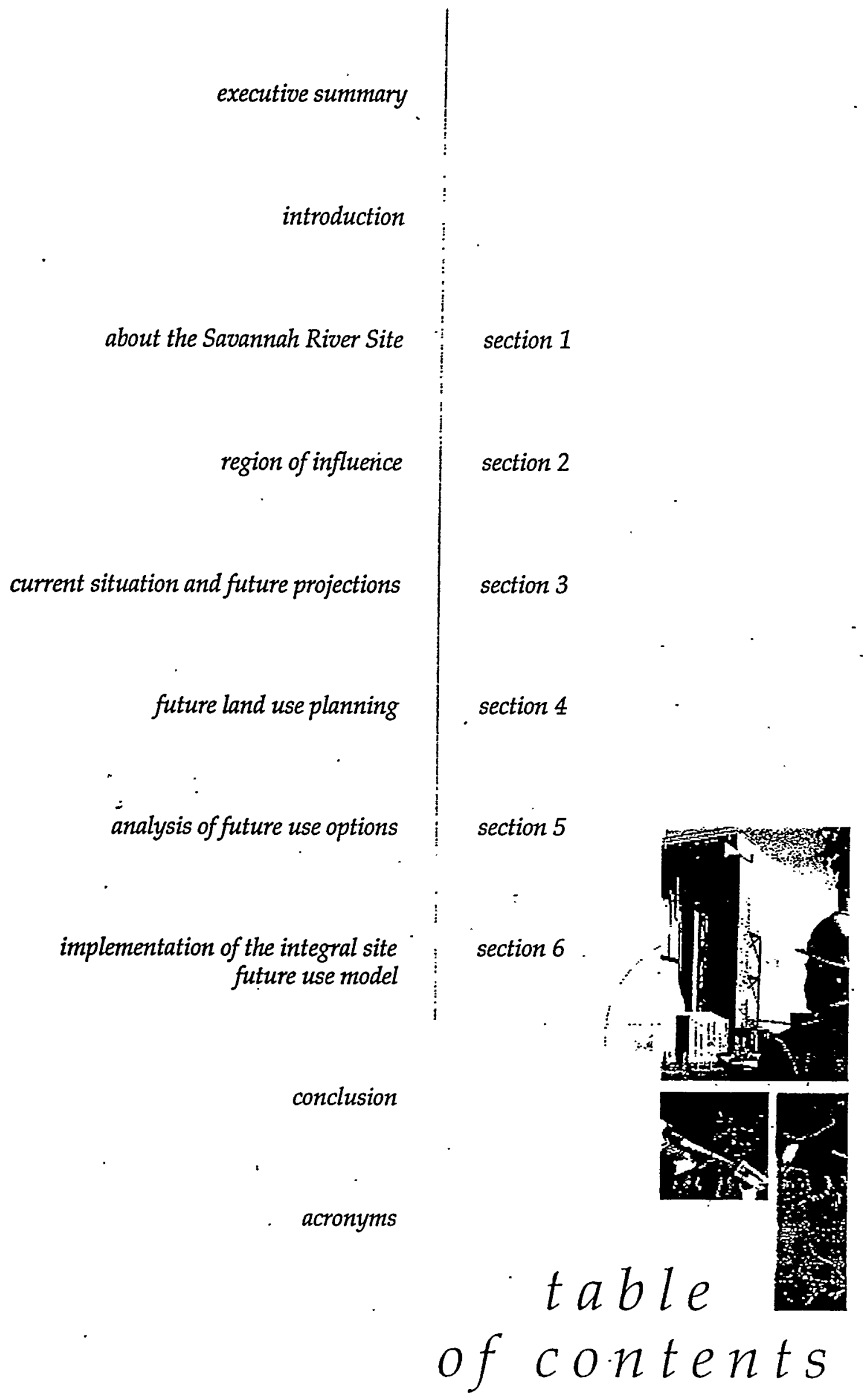



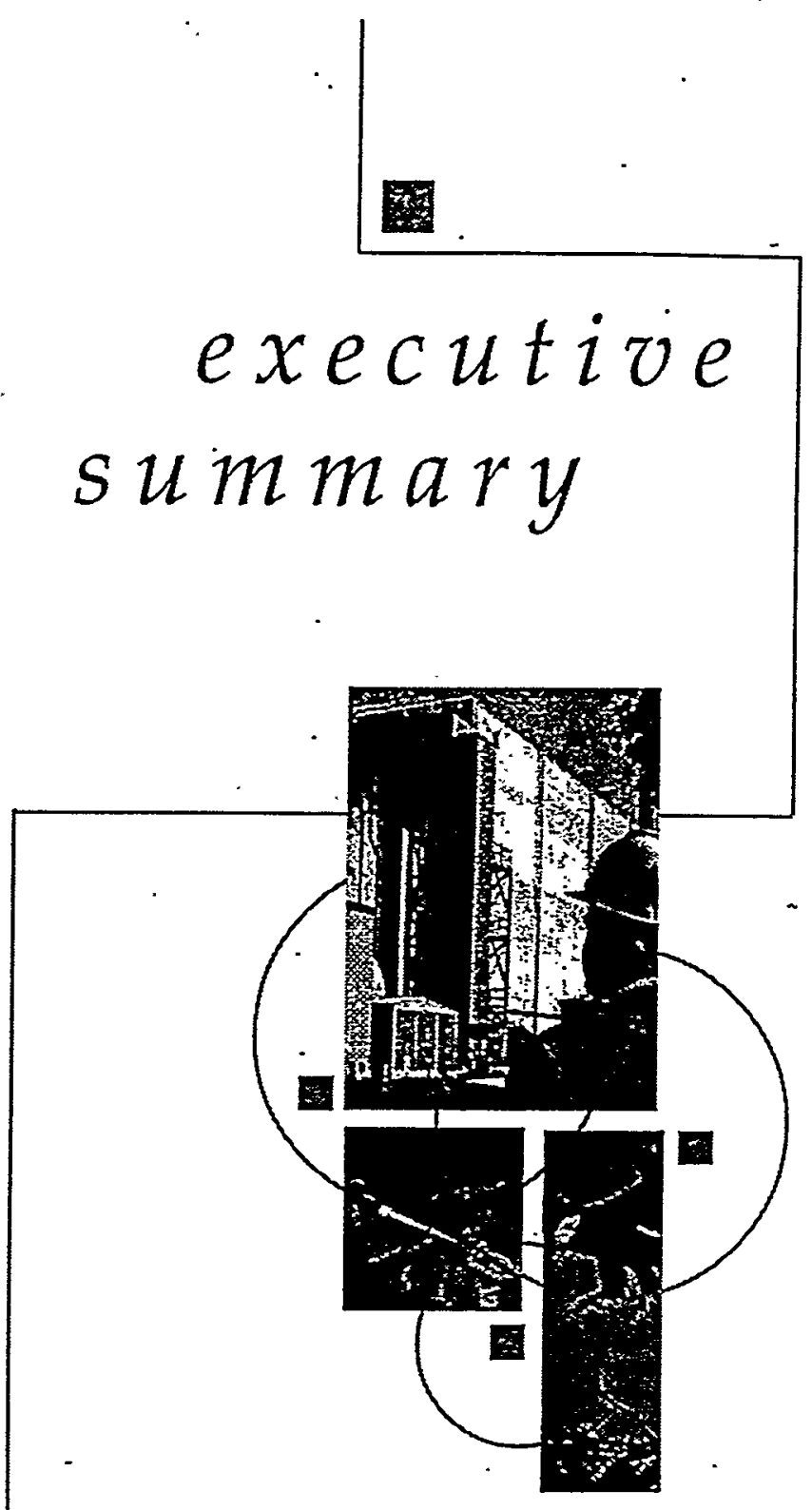
els presented in this plan: Consolidated Core, Residential, Disaggregate, and Integral Site. SRS personnel determined that the Integral Site Model most realistically accommodates development during the next 50 years and is therefore the approach for future-use planning.

The Integral Site Model easily accommodates current missions and those of the future; maintains maximum use of buffer zones; allows for research, natural resource management, biological diversity and cultural maintenance; and supports one of the largest natural expanses east of the Mississippi River.

To implement this model, SRS staff developed a zoned planning concept to address particular futureuse planning circumștances, focusing on simultaneous, concurrent, compatible land use. The planning model divides the site into three principal planning zones - Industrial, Industrial Support, and Restricted Public Use.

The most intensive use occurs at the site's center, becoming less intensive as the site boundary is approached. In this manner, the impact on surrounding localities is minimized, security is maintained, and the established safety buffer remains intact.

\section{executive}

\section{summary}

Effective implementation of the Integral Site model using the zoned planning concept will ensure that SRS remains a viable site into the future through concurrent, compatible land use. 
The purpose of the Future Use Plan is to establish a planning baseline and a path forward so Savannah River Site (SRS) management can make effective future-use decisions. The plan integrates site missions, ecology, economics, and cultural and social factors in a regional context.

Sound future-use decisions must also be made in the context of SRS and Department of Energy (DOE) Headqquarters strategic plans, which define the values, goals, and objectives to be considered in evaluating future-use alternatives.

SRS has five areas of strategic focus, described in the December 1997 SRS Strategic Plan: National Security, Nonproliferation, Environmental Quality, Science and Technology, and Corporate Management. The current situation and mission projections relating to each area for the next 50 years (considered the planning horizon) are addressed in this plan.

SRS is a 310 -square mile site in south-central South Carolina acquired by the federal government in 1951. The original facility layout of SRS isolated major production operations near the center of the site, creating a natural buffer zone to enhance nathonal security and public safety. In addition to its . primary national security and environmental man-

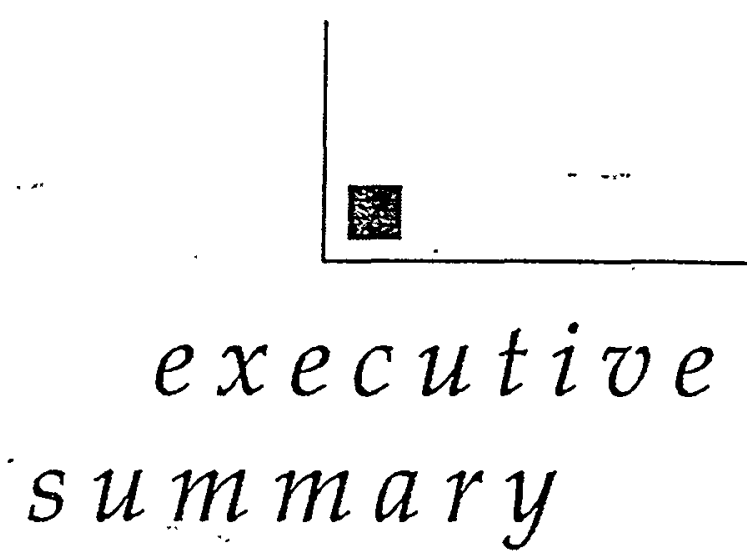

agement missions, SRS has played an important economic role during the last four and a half decades. SRS infuses more than $\$ 1.5$ billion annually into the economies of South Carolina and Georgia, provides thousands of jobs, conducts environmental and advanced technology research, and offers business development programs for local communities. Presently, over 13,000 employees work at SRS in various organizations.

The information in this plan and current futureuse policy, goals, and objectives for SRS are the result of significant efforts over the past several years. In preparing to analyze future-use options, SRS used years of input from external and internal stakeholders, site management, and DOE Headquarters to produce the SRS Future Use Map. A similar process was employed to create and evaluate the four mod- 

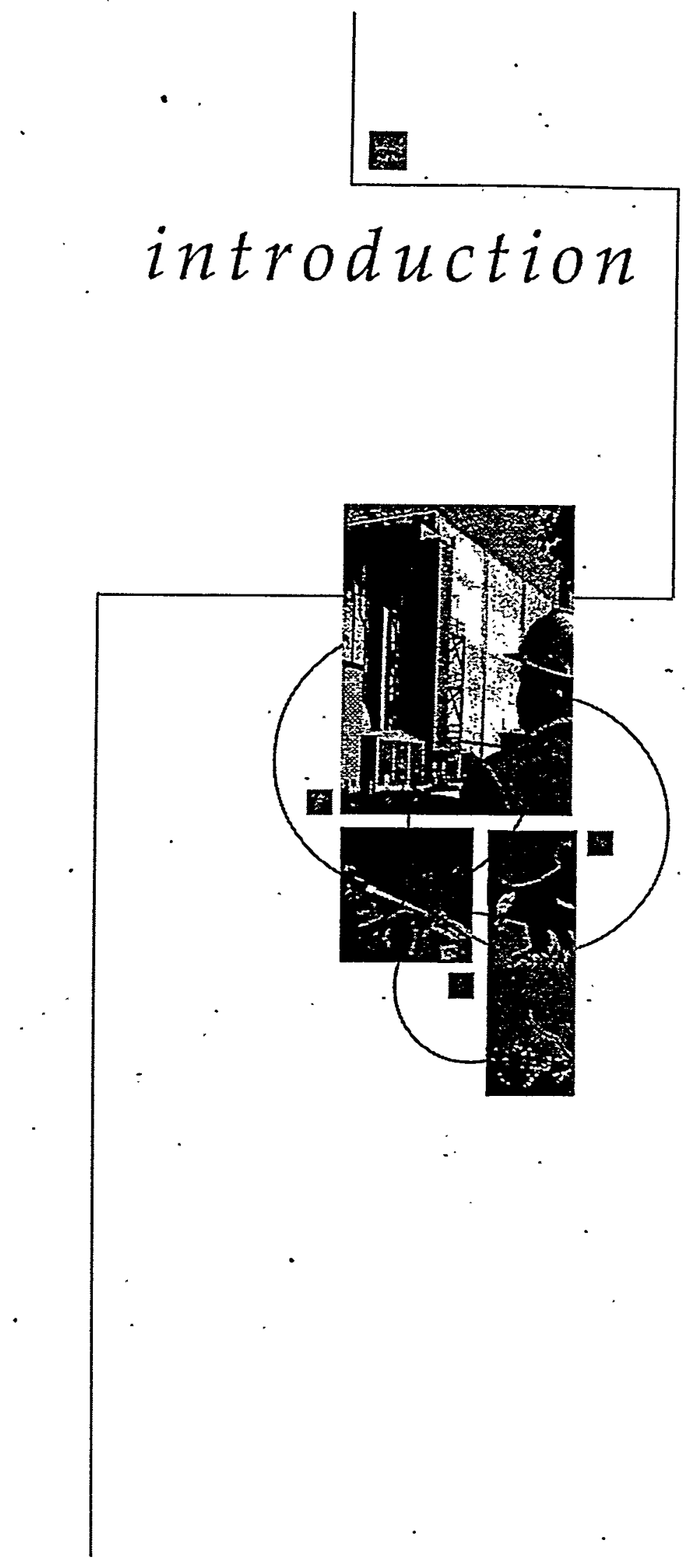
purpose

The Future Use Plan establishes a planning baseline and a path forward allowing Savannah River Site (SRS) management to make effective future-use decisions. This plan integrates the site's missions, risks, hazards, ecology, economics, and cultural and social factors in a regional context to aid in effective decision-making. It articulates missions and requirements from a future land-use perspective. This plan will be expanded to include more details on facilities, infrastructure, cultural resources, and natural resources to become a comprehensive plan for the site.

\section{the srs comprehensive planning process}

Comprehensive planning is a systematic, sitewide process for developing, approving, revising, and integrating plans with budget formulation, budget execution, and program evaluation. The process includes customer input and stakeholder involvement; the Executive Board involving all major Department of Energy (DOE) and other site organizations; and the Planning Board supported by a planning staff. The Executive Board articulates its vision for the future in the SRS Strategic Plan. Specific

\section{introduction}

courses of action designed to implement the goals and objectives of the Strategic Plan are developed through the Planning Board. These action plans are documented in a series of plan elements which, when completed and integrated, become the site's comprehensive plan. This Future Use Plan defines the current situation and outlines actions needed to move from the present to the future, guiding the allocation of land and resources.toward attainment of SRS goals and objectives.

The comprehensive planning process is promulgated in a Savannah River Implementing Procedure (SRIP 430.2), which establishes a planning staff responsible for identifying issues, developing background data, pinpointing the decision context. (including objectives and constraints), identifying potential alternatives, and considering input from cus- 
tomers and stakeholders.

This information is presented to the Planning Board, which ensures that the evaluation process reflects a sitewide perspective and effectively integrates concepts and proposals. The Planning Board considers the relevant facts and implications of each alternative and arrives at a conclusion as to the most appropriate course of action.

The Planning Board then forwards its recommended conclusion to the Executive Board, which ensures that site interests are considered from a management perspective. Once a position is established by the Executive Board, the Site Manager makes the final decision on acceptance of the recommendation. The chart below depicts this process.

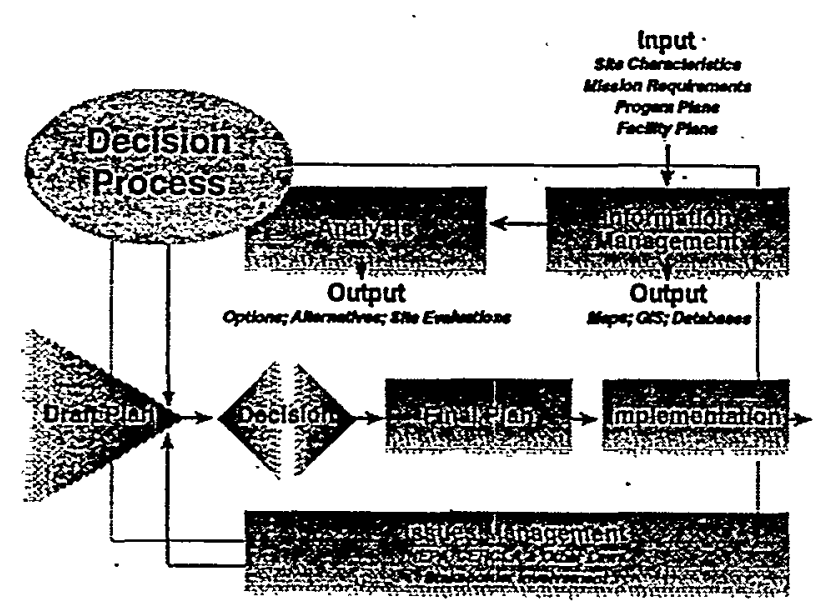

Future-use decisions must be made in the context of current SRS and DOE Headquarters Strategic Plans, which define the values, goals, and objectives considered when evaluating future-use alternatives.

As described in the December 1997 SRS Strategic Plan, SRS has five areas of strategic focus: National Security, Nonproliferation, Environmental Quality, Science and Technology, and Corporate Management.

The first four areas of focus are associated with products and services essential to achieve the customer goals of SRS. (See "Current Situation and Future Projections" for more detail on these focus areas.)

The fifth area of strategic focus, Corporate Management, addresses the fundamental business principles, values, and systems critical to the success of the four product/services focus areas.

Infrastructure, a component of the Corporate Management focus area, is addressed briefly in this plan and will eventually be a separate plan element. 
stakeholder participation.

In January 1994, DOE initiated a Complex-wide process to seek stakeholder recommendations on future uses of DOE land and facilities. The first product resulting from intensive stakeholder interaction was the January 1996 Future Use Project Report, reflected in the present SRS Future Use Policy (see the Future Use Policy section of this plan). For this plan, as with the 1996 report, SRS personnel received input through meetings, workshops, presentations, e-mails, one-onone discussions, telephone conversations, and letters. Personnel from SRS solicited feedback from offsite stakeholders within 150 miles of the site to ensure ample opportunity for them to contribute to this process.

Both onsite and offsite stakeholders provided valuable input and feedback on draft maps, future use policies, and ideas on specific future projects when this plan was being prepared.
Representatives from the organizations listed below, as well as others, played a key role in developing and reviewing site planning documents:

- Lower Savannah Council of Governments

- Columbia County Planning Department

- Aiken County Plarning Department

- City of Aiken Planning Department

- Augusta Planning Department

- Tri-County Alliance

- Central Savannah River Area Regional

Development Center

- Consortium for Risk Evaluation with Stakeholder Participation

- SRS Citizens' Advisory Board

- Citizens for Nuclear Technology Awareness

- Savannah River Ecology Laboratory

- Savannah River Natural Resource

Management and Research Institute 


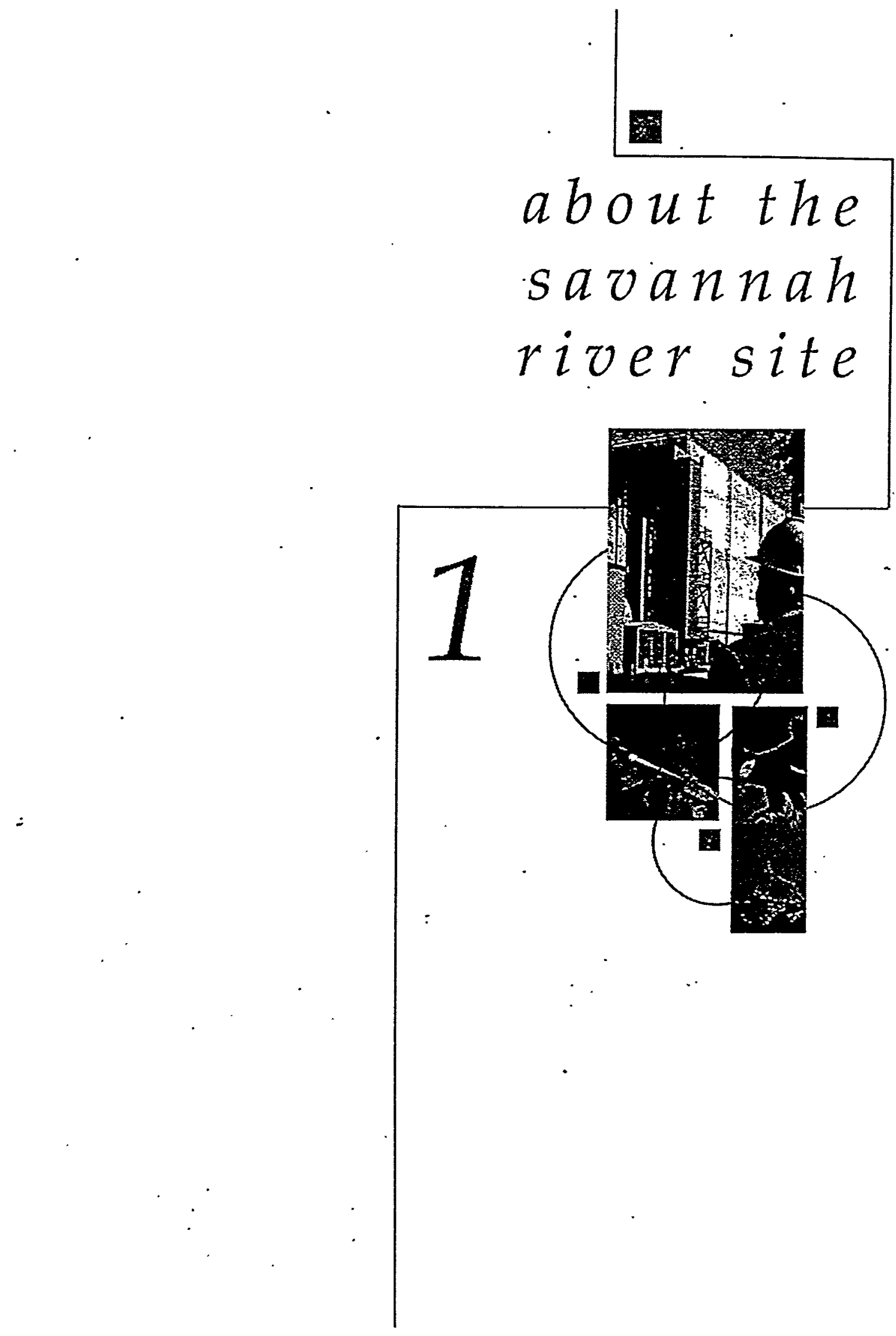




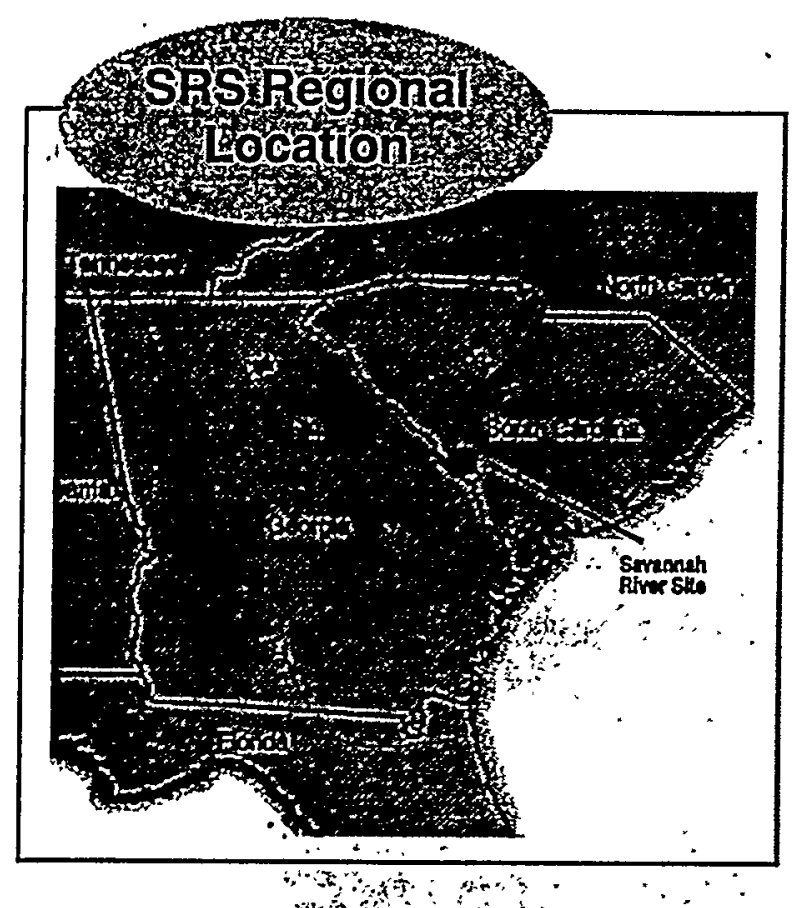

\section{site description}

The Savannah River Site (SRS) covers 310 square miles in south-central South Carolina on the Georgia border. The Department of Energy (DOE) manages SRS as a controlled area with limited public. access. Except for site facilities, the land is covered with natural vegetation. Open fields and pine and hardwood forests comprise 73 percent of the site; wetlands, 'streams, and two large reservoirs cover. approximately 22 percent; and production and support areas, roads, and utility corridors account for the remaining five percent. Land adjacent to the site is used mainly for forest and agricultural purposes.

The site includes several production, support, service, research and development, and waste management areas. In the original facility layout, major radioactive operations were isolated near the center of the site to create a buffer zone that reduced the risk of accidental exposure to the general public and provided additional security. 


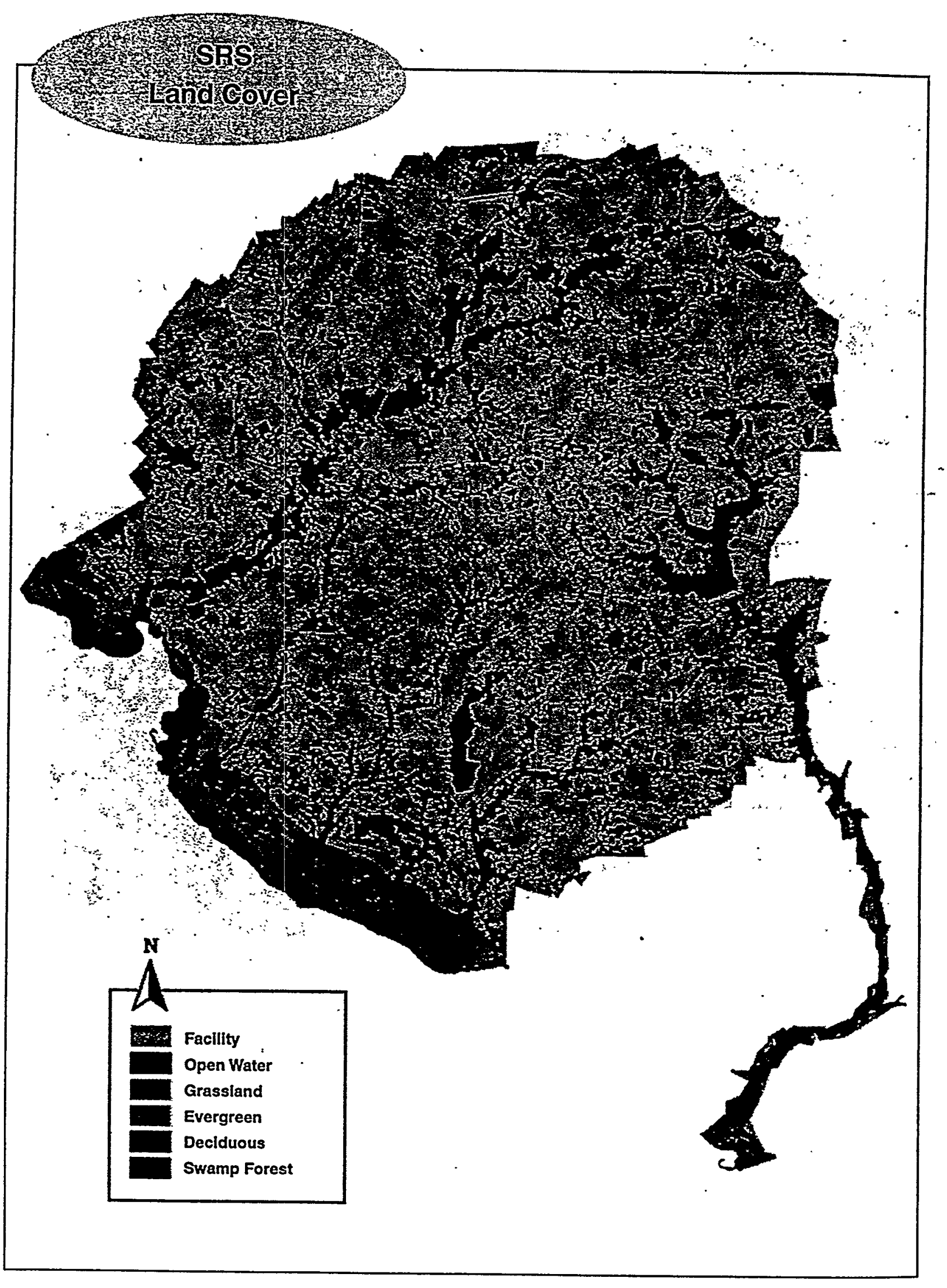




\section{site employers and employment}

At the beginning of calendar year 1998, over 13,000 permanent employees worked at SRS in the following organizations:

- DOE-SR (525 permanent employees) is responsible for overall management and contractor oversight.

- Westinghouse Savannah River Company and its partners $(11,600$ permanent employees and subcontractor and 700 temporary employees) are responsible for management and integration of the site.

- Wackenhut Services, Inc. (741 permanent employees) is responsible for site security.

- The University of Georgia's Savannah River Ecology Laboratory (128 permanent employees) provides site ecological evaluations and research.

- The Savannah River Natural Resource Management and Research Institute ( 89 permanent employees), a unit of the U.S. Forest Service, is responsible for managing the site's natural resources.

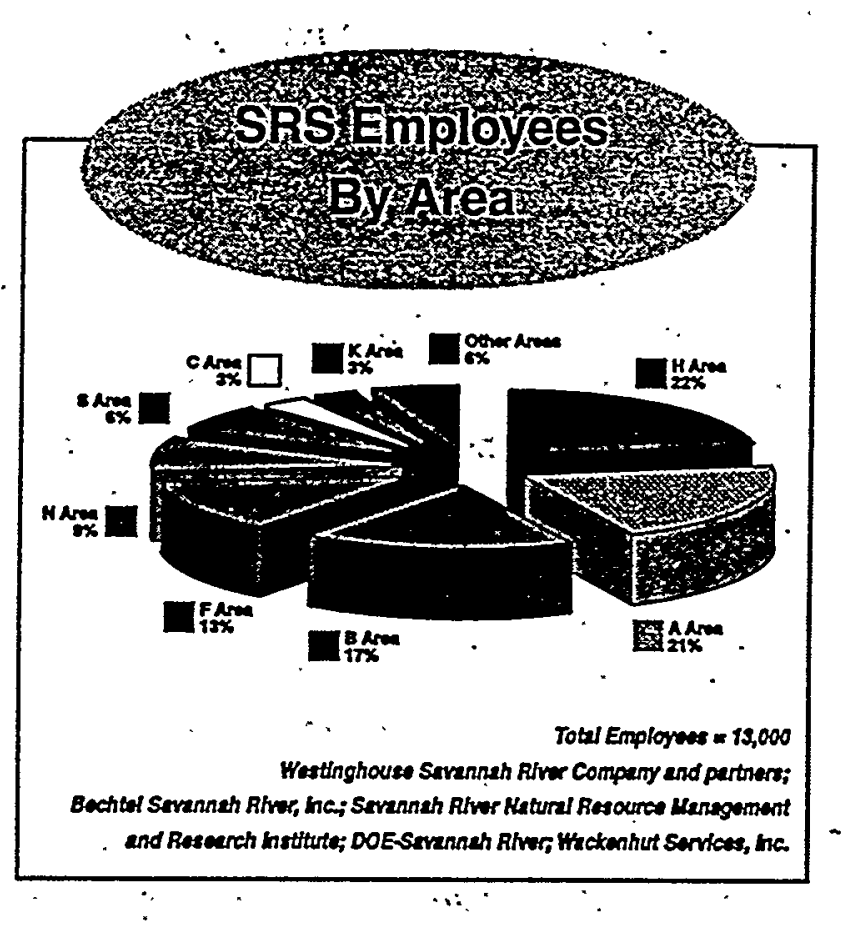

Support-service contractors for DOE-SR added over 80 permanent employees, and approximately 30 employees worked for other entities (the University of South Carolina Institute of Archaeology and Anthropology, the U.S. Department of Agriculture's Natural Resources Conservation Service, the Army Corps of Engineers, and the South Carolina Department of Natural Resources).

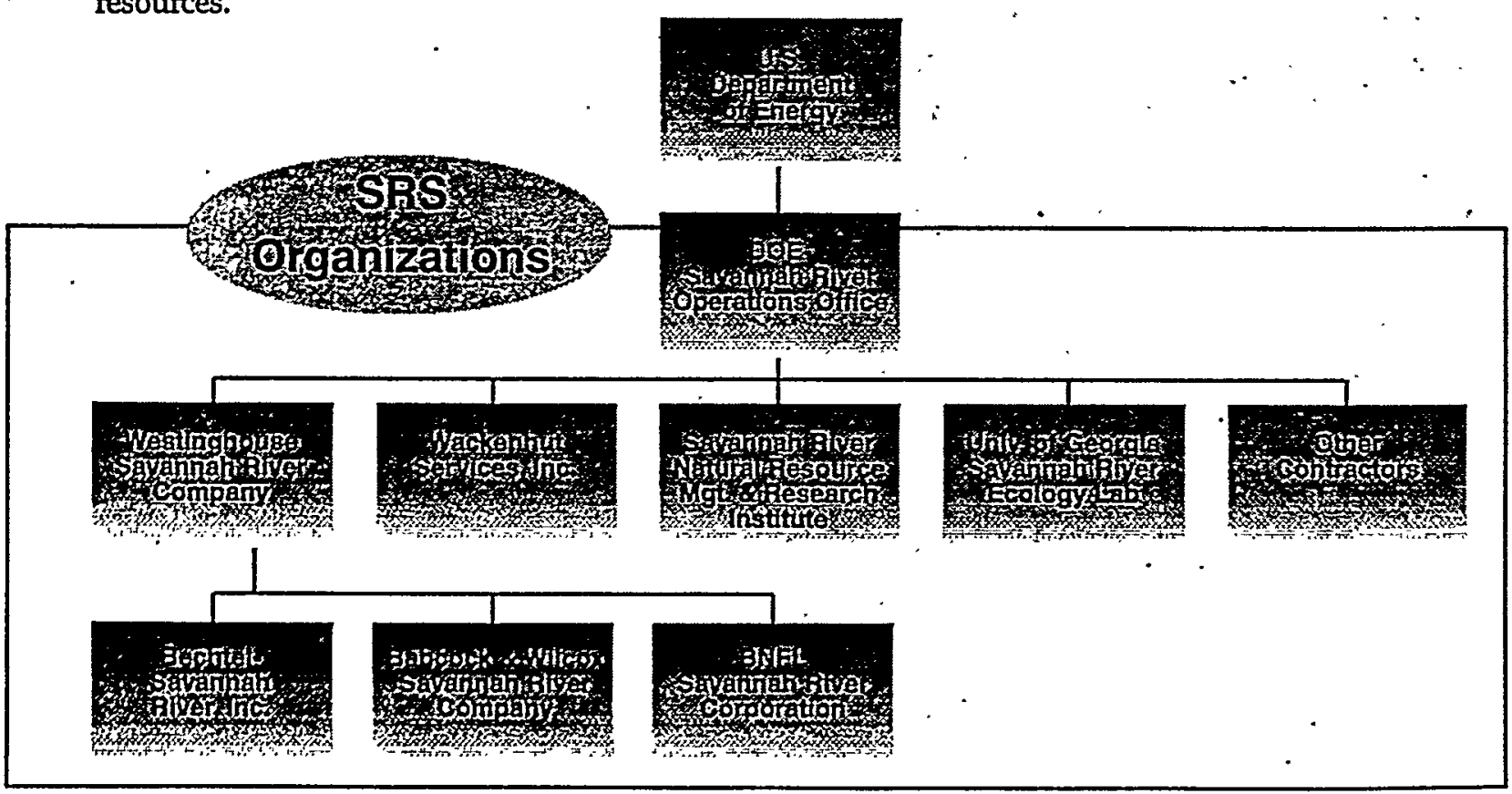




\section{history and background}

SRS was acquired by the federal government in early 1951 for about $\$ 19$ million. Much of the property was farm and forest land of low quality. The University of South Carolina Institute of Archaeology and Anthropology reported that overflight photography showed 80 to 90 percent of the future site was farmland in "degraded condition". Wildlife populations had been depleted by rearly 200 years of over-hunting and explöitation.

Beginning in the early 1950s, however, vegetation re-established on the degraded land helped stabilize and rehabilitate the soil to better support native plant and animal life. By 1953, SRS re-vegetation efforts represented the largest mechanized tree planting operation in the United States. By 1968, over 100 million trees had been planted. With protection provided by the site's limited access and the reforestation of farms, wildlife populations recovered and flourished. Whitetailed deer populations expanded to the point that a controlled public hunting program was initiated in 1965. Wild turkeys were stocked at SRS in the early: 1970s; their population has also expanded rapidly.

Over the next several decades, cultural, ecologi$\mathrm{cal}$, and environmental research funded by DOE provided extensive databases on the SRS environment. From the beginning, research was undertaken in direct support of site manufacturing activities. In 1972, SRS was designated as the ration's first National Environmental Research Park (NERP) by an Executive Order that provided for tracts of land where the effects of human impacts on the environment can be studied.

An integral component of the SRSNERP is the SetAside Program, which has evolved from a few representative tracts to 30 areas representing 7 percent of the total site area and all of the major plant communities and habitat types indigenous to the site. (Please see Existing Use map in Section 6.)
Scattered across the site, these 30 areas have been set aside for ecological research and are protected from public access and most routine site maintenance and forest management activities. In addition, these Set-Asides preserve habitats for endangered, threatened, or rare plant and animal populations. 

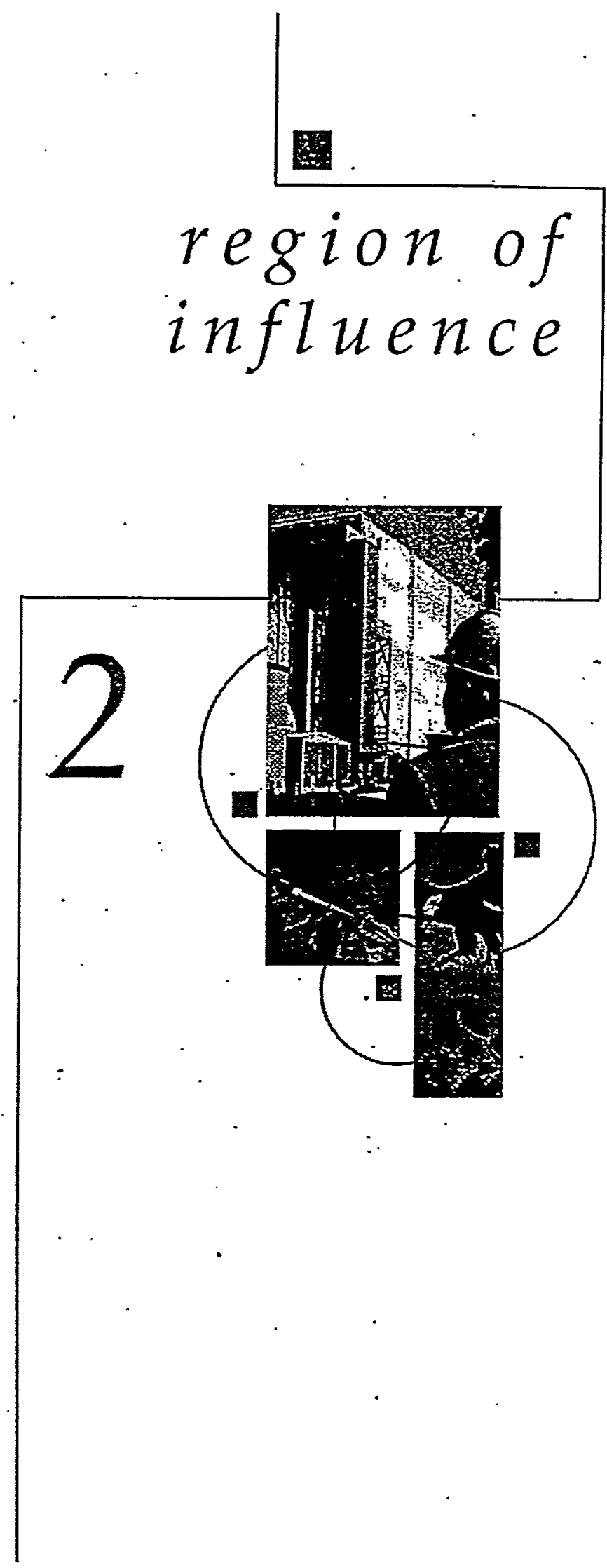
The Savannah River Site (SRS) Region of Influence in the area outside the site boundary affecting and affected by site activities. The site is located in the Central Savannah River Area (CSRA) that consists of nine counties in South Carolina and Georgia. The southwestern boundary is the Savannah River, the recipient of most of the area's tributaries. The river currently supports industry, recreation, and natural habitat.

SRS is situated in three major land resource areas: thi: Southern Piedmont the Carolina and Georgia Sarld Hills, and the Atlantic Coastal Plain. The region contains 10 county governments and 38 incorporated areas. SRS enjoys strong community support from the local jurisdictions, chambers of commerce, educational institutions, and other groups who have put political differences aside to keep and add missions at SRS.

Land use around SRS centers on residential, industrial, commercial, transportation, recreation, and agricultural activities. Upland pine and wetland forests comprise a large percentage of the area, and the topography and other existing physical features and conditions greatly influence land development decisions and policies. Because of the soil types and lack of steep slopes, the area is well suited for both agriculture and urban development. The land use surrounding Augusta, Ga., and Aiken, S.C., is primarily agricultural, but residential, commercial and industrial activity are becoming more prevalent. Augusta, the Fort Gordon Military Reservation and SRS comprise a significant amount of the total developed area.

In 1990, the population of the CSRA was slightly under 500,000, primarily located in Aiken County in South Carolina and Columbia and Richmond counties in Georgia. Over 70 percent of the population lived in areas classified as urban. The urban- 
rural mix of the region mirrored that of the United States in general but was more urban than other areas in South Carolina and Georgia. The population density of the region was almost twice that of the nation but had approximately the same percentage of female and male inhabitants. The CSRA population was classified as 37 percent minority. Augusta is the area's largest city, with a current population of approximately 190,000 .

The major economic sectors in the region are agriculture, forestry, fishing, mining, construction, manufacturing, transportation, wholesale trade, retail trade, finance, insurance, real estate, services and government. The industrial uses in the region include a commercial two-unit nuclear reactor power plant, a regional low-level waster repository, and a wide variety of conventionalindustries Manufacturing and government account for almost half of all jobs in the region. $D O E$ is a significant presence in the region and one of South Carolina's largest employers.

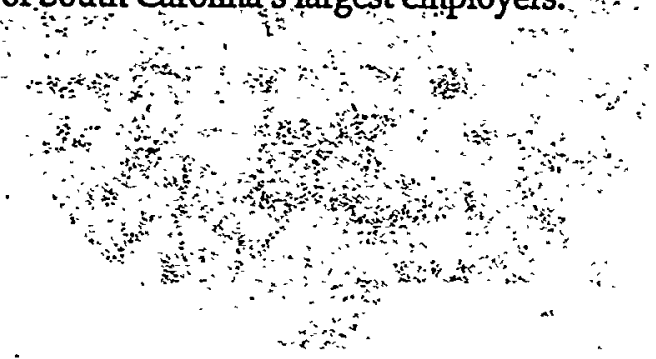




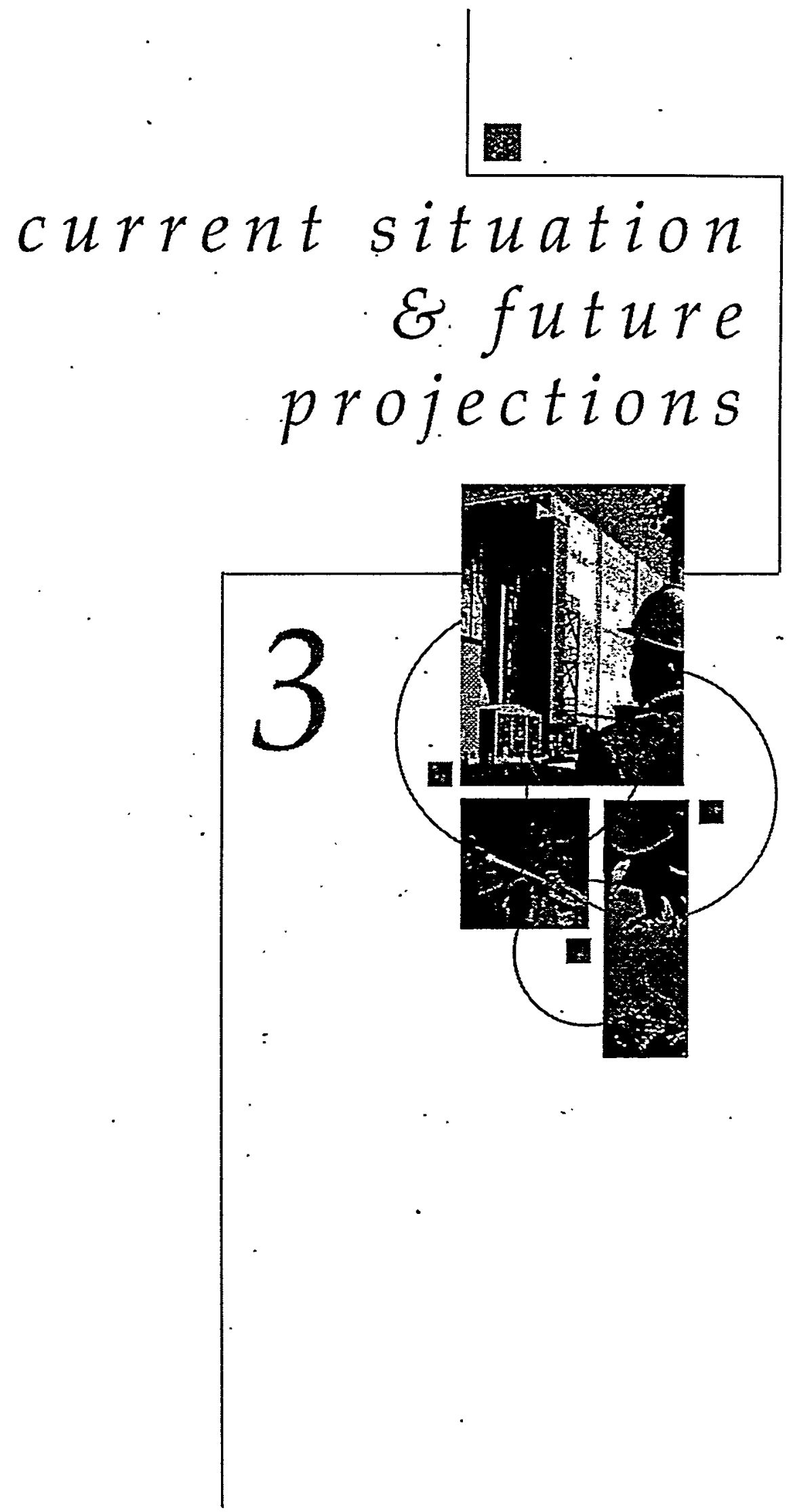


This section describes the current situation and mission projections through the next 50 years for each of the four product/service strategic focus areas at the Savannah River Site (SRS) (National Security, Nönproliferation, Environmental Quality, and Science and Technology) and also addresses the infrastructure component of the Corporate Management strategic focus area.

\section{national security}

The SRS National Security mission includes maintaining both the SRS techrical expertise in tritium operations, production, and engineering and an effective level of protection for nuclear materials, facilities, 'governmental assets, classified material, SRS employees and the public.

\section{tritium supply}

SRS is responsible for the nation's tritium recycle mission. The objectives of the Tritium Program are to provide tritium and non-tritium loaded reservoirs to meet the requirements of the Nuclear Weapons Stockpile Memorandum, to conduct Reservoir Surveillance Óperations and Gas. Transfer System testing, and to manage existing tritium inventories and facilities. Related activities include recovering, purifying, and storing tritium from dismantled weapons; recycling and loading weapon components for the stockpile; and extracting tritium from remaining irradiated targets. SRS has become the single storage location for bulk quantities of tritium by consolidation of tritium operations from other Department of Energy (DOE) sites.

The tritium mission is carried out in a 25-acre compound within the H-Area chemical processing facilities. Under the Tritium Facility Modernization and Consolidation Project, several existing process systems, equipment, and process functions will be relocated to existing buildings within the Tritium

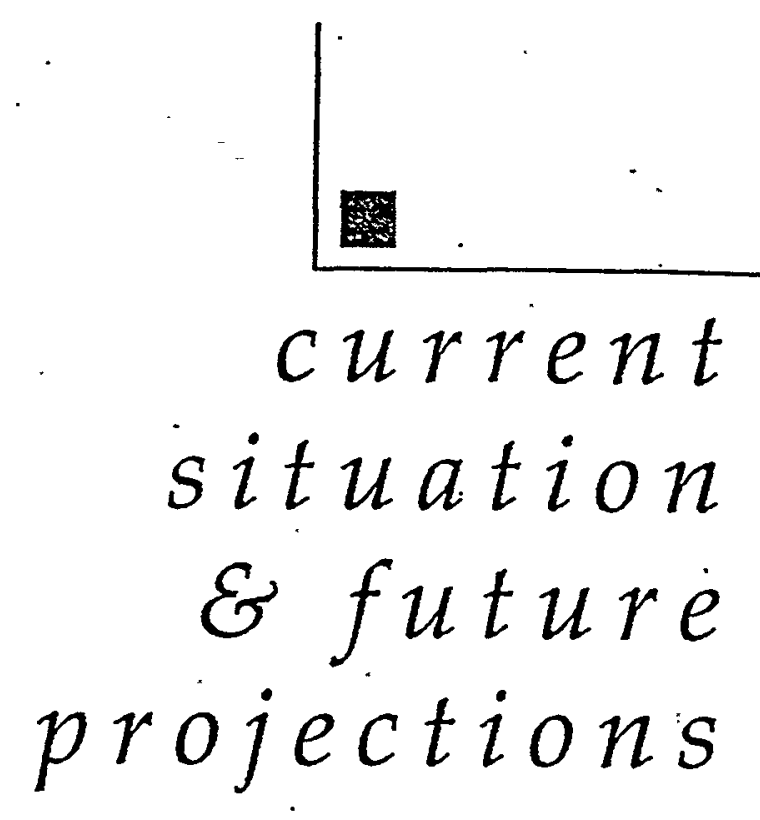

Facility in order to reduce "footprint" and operating costs. Additionally, this project will provide the capability to process tritium from the Tritium Extraction Facility (TEF), and/or the Accelerator Production of Tritium (APT).

Under ongoing Environmental Impact Statements, DOE is currently considering two technical options, or a combination of the two options, for supplying tritium in the future. A decision by the Secretary of Energy is expected by late 1998.

: One option is to purchase irradiation services with the option to purchase an existing commercial reactor for conversion to a defense facility. The other option is to install a proton accelerator for the production of tritium. For both options, SRS will provide facilities.

For future land-use planning purposes, the new facilities are expected to respond to an enduring demand extending for a 40-year or longer service life. Land-use impacts of the two options are discussed on the next page. 
TEF: DOE is planning the construction of a new Tritium Extraction Facility at the Savannah River'Site. Under present planning scenarios, construction would begin during fiscal year 2000, with commissioning and operation projected to begin in 2005. In order to maintain a nuclear deterrent capability, this facility would operate throughout the 40-year planning horizon. The facility would require the industrial development of about four acres adjacent to the existing tritium facilities. Associated with the industrial facility will be modest expansion of utility and transportation corridors, mostly within the existing industrial area.

APT: DOE is also considering construction of a proton accelerator, approximately one mile in length, with associated facilities. Facilities would include the proton generator, accelerator, target/blanket, and extraction facilities. Under present planning scenarios, construction would begin during 1999, with commissioning and operation projected for around 2007. In order to maintain a nuclear deterrent capability, this facility would operate throughout the 50-year planning horizon. This option would require a new industrial area of approximately 300 acres to be developed. Siting studies have been conducted to identify suitable locations at SRS for the new facility, and characterization of the preferred site is under way. In addition to the new industrial area, new transportation corridors and utility corridors would be established to support the facility.

\section{plutonium pit manufacturing}

DOE has initiated its Science Based Stockpile Stewardship Program for the enduring nuclear weapons stockpile. Currently, the projected need for new plutonium pits is low. Should the need be increased significantly, another production site may be considered. Because of the experience in plutonium operations and the long-term defense mission of tritium supply, SRS is considered a candidate site for this potential mission. Since the reuse of existing facilities has been pro- posed, future land-use impacts are expected to be minimal, and no new industrial development is forecast.

\section{safeguards and security}

The SRS Safeguards and Security mission is to maintain an appropriate level of protection for the site's nuclear materials, facilities, government assets, classified material, SRS employees, and the public through the effective, integrated use of highly trained protective force personnel, physical security systems, and administrative controls. While many other DOE sites are reducing or eliminating their majornational security assets, SRS is expanding its role by storing additional nuclear materials from other DOE sites and from nonDOE facilities, with a commensurate increase in classified and sensitive unclassified information.

SRS protective force operations are located in BArea. Protective force elements operate out of areabased offices, with the majority of employees staffing security posts interior and exterior to the site's operational facilities. Major equipment used to perform the SRS security mission includes helicopters, vehicles, watercraft, weapons/ammunition, détection devices, firing ranges, and a multimedia computer lab. A stateof-the-art site-wide intrusion detection and access control system is currently operational. In-house technologies include computer-bàsed modeling systems, a joint tactical simulation system, computer-based training systems, and a comprehensive array of engagement simulation system weaponry.

Future needs in addition to ongoing operational activities, include physical protection systems in new facilities such as the Actinide Packaging and Storage Facility and the Spent Fuel Treatment and Storage Facility (SFTSF). Significant investment in hardware and software will be required to maintain computer and information security as the speed, volume, and technology of the Internet and electronic mail traffic expand exponentially in the future. Classification review and export control activities will expand to meet new 
International Atomic Energy Agency requirements. Safeguards activities will also expand to support receipt and accountability for additional nuclear materials transferred to SRS for stabilization and interim storage.

\section{nonproliferation}

The goal of the SRS nonproliferation activities is to provide safe, secure, long-term storage and disposition of excess fissile materials, to advance the progress of DOE in accountancy of nuclear materials, and to achieve national and international nonproliferation objectives.

\section{plutonium disposition}

DOE is currently pursuing a dual path strategy for the disposition of up to 50 metric tons (MT) of surplus plutonium. One option involves immobilizing plutonium inventories in a ceramic form for disposal with the high-level waste glass produced in the Defense Waste Processing Facility atSRS. Under the other option, plutonium would be made into mixed oxide (MOX) fuel for irradiation in a commercial light-water reactor and disposal as spent nuclear fuel. SRS has been designated as the preferred site for the immobilization mission and is a candidate site for the MOX mission. In addition, the plutonium in surplus weapons components (pits) must be converted into plutonium oxide for introduction to either disposition path. SRS is also a candidate site for this pit disassembly and conversion mission.

The siting decision for these missions is the subject of an Environmental Impact Statement (EIS) currently in progress, with a final EIS expected in January 1999. Implementation of the scenario proposed below is dependent upon the results of the subsequent Record of Decision, which is expected in February 1999. Because SRS is already constructing a new plutonium storage vault, one concept for deployment of the three missions would be to create a new Plutonium Disposition Complex to take advantage of the common facilities for shipping, receiving, assay, and storage provided by the new vault. Projections are to start construction by the year 2000 , with operations beginning between 2005 to 2007. The program to disposition the $50 \mathrm{MT}$ of surplus plutonium is estimated to require approximately 10 years of operation; however, additional materials could be declared surplus if the U.S. and Russia agree on further reductions in their respective nuclear weapons stockpiles, potentially extending this mission.

\section{enriched uranium blenddown}

The U.S. has declared 174.3MT of highly enriched uranium as surplus to future needs. One path for disposition of the uranium is to make it suitable for use in commercial reactors by blending down the uranium content to approximately five percent or less, making the material unsuitable for use in nuclear weapons. The site is also being considered as a site to install the blenddown facilities to convert certain categories of surplus uranium. The facilities are proposed for an existing chemical processing area in $\mathrm{H}$ Area. Other alternatives are also being considered. $: a ., \ldots$. 
權

\section{environmental quality}

The goal of the SRS Environmental Quality programs is to demonstrate excellence in environmental stewardship. In this area, seven activities are addressed: Nuclear Materials Stabilization and Storage, Spent Fuel Storage, High-Level Waste, Solid Waste, Natural Resources, Environmental Restoration (ER), and Surplus Facilities Disposition.

\section{nuclear materials}

\section{stabilization and storage}

SRS Nuclear Materials Stabilization and Storage Program goals are to safely stabilize, store, and disposition the site's legacy nuclear materials in a cost-effective and environmentally sound manner; to receive, stabilize, and store plutonium from other DOE sites; to develop partnerships with Rocky Flats and Hanford sites to accelerate clean-up and reduce life-cycle costs; and to maintain storage and operating facilities for potential future missions while transitioning facilities that have undefined missions to minimum surveillance and maintenarice status.

The site's chemical separations facilities support DOE's commitment to implement Recommendation 94-1 from the Defense Nuclear Facilities Safety Board (DNFSB). In 1997, the Secretary of Energy approved the SRS Phased Canyon Strategy for continuing execution of the DNFSB 94-1 recommendation that deals with the stabilization and interim storage of "at risk" legacy nuclear materials. This strategy uses existing processes and facilities specifically designed for these materials, optimizing the completion of materials stabilization, and minimizing the need for process development and facility modifications. This strategy will achieve expeditious stabilization of SRS materials and provide for the early stabilization of certain limited quantities of plutonium from the Rocky Flats Environmental Technology Site (should that option be selected upon completion of environmental reviews). This strat- egy also maintains the capability to use nonproliferation processes to implement potential plutonium and highly enriched uranium disposition missions (should those options be selected).

SRS is in the fourth year of an 11-year program to stabilize its legacy materials. F-Canyon material stabilization is currently scheduled for completion.by 2002 , and the H-Canyon material stabilization is scheduled for completion in 2004. The facilities will then transition to minimum surveillance and maintenance status until final decommissioning.

In general, existing facilities will be used to process materials that are candidates for stabilization. As no other stabilization capability exists for this material, new vitrification capabilities must be provided in F Canyon to stabilize the americium/curium. Until decisions are made on final material disposition, SRS is also constructing a state-of-the-art Actinide Packaging and Storage Facility to provide consolidated interim storage of the nuclear materials generated from stabilization. Modifications to an existing 235-F vault and Building 105- $\mathrm{K}$ are also planned for accelerated receipt of Rocky Flats plutonium, permitting cost savings from an earlier than expected Rocky: Flats closure (2006 vs. 2010), reducing Complex-wide life cycle costs.

\section{spent fuel storage}

The SRS spent fuel storage activities address six major areas: (1) receipt of offsite fuel from research reactors; (2) storage of unirradiated nuclear material and shipments to other facilities; (3) surveillance and maintenance of reactor facilities to limit risk; (4) heavy water processing and consolidation; (5) alternate technology development to provide a disposition option other than the conventional processing of aluminum-based spent nuclear fuel (SNF); and (6) development of the SFTSF to deploy the selected alternative technology and provide interim dry SNF storage and eventual deinventory to the geologic repository.

Currently, aluminum-based fuel assemblies from 
foreign and domestic research reactors are safely received and wet-stored in the Receiving Basin for Offsite Fuel (RBOF) and LrArea fuel storage basins. Offsite fuel receipts are scheduled to continue through 2035. Deinventory of offsite SNF from RBOF to the SFTSF is expected to begin in 2005 and to be completed in 2011. Completion of the L-Basin deinventory, including the SFTSE facility, is expected in 2035.

Site fuels (covered by DNFSB 941 disposition recommendations) are currently stored in $\mathrm{RBOF}$ and the disassembly basins of the $L$ and K-Reactor Areas. These fuels will remain safely wet-stored in these basins until the shipments to the site canyon facilities for stabilization are complete. The deinventory of all DNFSB 94-1 fuel materials is expected to be completed by the first quarter of FY2001.

Unirradiated highly enriched uranium (HEU) is stored in the K-Reactor Assembly Area and will remain stored in K-Reactor until facility demobilization begins. Current plans call for unirradiated HEU to be moved to L-Area when K-Reactor is deinventoried.

Inventories of heavy water will be purified to meet mission requirements in the future and sold as excess. inventory.Once processed and purified, heavy water may remain in storage indefinitely. Once the processing campaign has been completed, the D-Area facilitiés will be demobilized and decommissioned.

Technology alternatives to the conventional processing of aluminum-based SNF are expected to use the SFISF facility to condition offsite fuel. By FY1999, technology, process development; and wasteform performance will be developed for both the melt and dilute alternatives. Direct co-disposal technologies to support a technology decision are also expected by FY1999. The fuel will be packaged in a "road-ready" form for both shipment to and emplacement in the federal geologic repository. This facility is expected to be available to receive SNF during FY2005, pending authorization' of the project.

The 105-K building has been proposed as an in- terim receipt and storage facility for offsite plutonium, which could potentially extend the use of the facility beyond 2010. In addition, two new missions are being proposed for the 105- $\mathrm{L}$ building. The first proposal is for a traditional line item project to build the SFTSF facility in $105-\mathrm{L}$; this facility would replace the previous privatization proposal. This proposal continues use of L-Basin as the SNF receiving point until an unspecified date when a decision to build a dry receiving bay will be evaluated. The continued use of L-Basin and the accelerated deinventory of the RBOF facility provide substantial cost savings over the privatization approach. The second proposal involving the 105:L building is for a facility to detritiate heavy water prior to sale. This facility would be funded and constructed as part of the heavy water sales agreement currently being negotiated.

\section{high level waste}

The mission of the SRS High-Level Waste (HLW) Program is to provide safe and efficient receipt, storage, and processing of highly radioactive liquid waste to support site operations and DOE plans for permanent disposal of radioactive waste.

The HLW.inventory was as high as 35 million gallons (420 million curies) stored in 51 underground, interim waste storage tanks. This waste will eventually be removed from the tanks, separated into its lowlevel and high-level components, and properly disposed of either at a federal repository (high-level waste) or onsite at Saltstone (low-level waste). The HLW facilities constitute a highly integrated system involving waste storage; evaporation; removal of waste from tanks; waste pre-treatment; vitrification of the high-level waste component at the Defense Waste Processing Facility (DWPF); disposal of the low-level waste component at Saltstone; and interim storage of the vitrified glass canisters pending transfer to a federal repository.

The tank farms receive liquid waste, as generated, 
from the Separations Canyons (estimated at approximately 0.6 million gallons per year through FY2003); the RBOF (estimated at 360,000 gallons per year) and waste processing activities, particularly recycle water from DWPF and washwater from Extended Sludge Processing. For potential new SRS missions involving canyon processing (e.g., Rocky Flats or spent nuclear fuel), the HLW system would perform its same essential function as the final step in waste processing. For new missions involving dry storage or the APT, the HLW system would have no role.

Two of the 51 waste tanks have been closed. Of the remaining tanks, 22 are old-style tanks that do not meet current requirements for secondary containment and leak detection. These old style tanks must be removed from service to meet Federal Facilities Agreement regulatory commitments. The date to remove these tanks from service is currently under negotiation, but current projections target closure of old-style tanks by 2025. A second program driver is the Site Treatment Plan, which commits the DWPF to achieving an average production rate of 200 canisters per year until all current and future waste has been vitrified, but no later than FY2028. Current budget and schedule projections target a completion date of FY2024. The DWPF initiated radioactive operations in March 1996, filling 64 canisters the first year and 233 by the end of . FY1997.

\section{solid wäste}

The mission of this program is to efficiently and effectively treat, store, and/or dispose of solid waste. The near-term goal for this program is to install the treatment, storage, and disposal capabilities needed to enable SRS to take care of legacy wastes and reach a steady-state condition. The discussion that follows addresses four waste types (sanitary, low-level, hazardous/mixed, transuranic [TRU]), and three key waste management facilities (Consolidated Incineration Facility, Effluent Treatment Facility, and Saltstone).
Sanitary waste is currently disposed of at an offsite commercial municipal landfill. Closure activities on the onsite Interim Sanitary Landfill will begin in 1998 and be completed in 1999. A new onsite regional commercial landfill is expected to begin operation in 1998, at which time SRS will stop offsite operations and ship waste to the onsite landfill.

Low-Level Waste is received from generators and is segregated into categories. A new sorting facility with shredding capability is expected to begin operation in 1998. In combination with onsite compaction and incineration, the sorting facility will permit solid waste to meet its steady state operation objective between 2000 and 2005 and possibly extend the life of the current vaults indefinitely by maximizing direct disposal. A second disposal vault will be necessary around 2010, in part to support a new SRS tritium production mission Disposal methods or facilities are also needed for long-lived waste, which is currently being stored until technology can be developed, and for contaminated large equipment.

Hazardous waste is currently stored at SRS and treated either offsite at a commercial facility or onsite in the Consolidated Incinerator Facility. All legacy hazardous waste will be shipped by the year 2002, and steady-state operation is anticipated at that time.

Mixed waste is being managed to achieve full Land Disposal Restriction compliance per Resource Conservation and Recovery Act (RCRA). This will be accomplished by developing treatment methods meeting Site Treatment Plan requirements or disposal alternatives. Treatment technology remains undetermined for a limited number of waste streams. All legacy waste will be treated by 2019 and disposed of by 2020 , except tritiated oil, which will remain in storage until the tritium decays or treatment technologies are developed. Storage will continue to be provided for the interim storage or staging of newly generated mixed waste awaiting treatment and/or disposal. An options analysis for the transport and disposal of mixed 
waste will be performed in 1998 and repeated periodically to update and optimize the disposal process. The current goal for disposal of the first treated mixed waste is 1999.

TRU waste in inventory is currently being characterized to segregate it from low-level and mixed lowlevel waste and to prepare TRU waste for ultimate disposal at the Waste Isolation Pilot Plant (WIPP) in New Mexico. The TRU waste management process has five major objectives: (1) continue safe storage, including retrieval of earth-covered drums; (2) obtain capabilities to characterize, certify, and transport waste to WIPP; (3) disposition low-level (formerly TRU legacy) waste; (4) establish the infrastructure to support privatization initiatives to process waste; and (5) identify a path forward for the disposition of inixed lowlevel alpha contaminated waste. A Ship-to-WIPP initiative will establish the systems needed to"support initial shipments of waste to WIPP. For the future, a TRU waste facility is planned to process high activity TRU waste from 2012-2032. Privatization initiatives will be implemented as appropriate for waste treatment. If WIPP is not operational by July 1998, discussions with the South Carolina Department of Health and Environmental Control (SCDHEC) will begin regarding treatment alternatives for mixed TRU waste.

The Consolidated Incineration Facility (CIF) provides the capability to treat low-level radioactive waste, hazardous waste, and mixed wastes. Operation of the CIF will contribute to the implementation of the Site Treatment Plan. Ash and blowdown that is produced will be transferred to either a storage facility or disposal facility, depending on its regulatory designation. The CIF will continue to process identified waste streams and be adapted to other generator treatment needs as necessary.

The Effluent Treatment Facility (ETF) provides the capability to remove hazardous and low-level radioactive contaminants from the waste water generated from the F- and H-Area Separations and Tank
Farm areas and ER purge water. The ETF is currently being operated under a SCDHEC Waste Water Permit. On average, ETF processes $18,000,000$ gallons of waste water annually. In addition to its discharged water, $150,000-300,000$ gallons of concentrate are transferred to Saltstone for disposal. The ETF will continue to operate as necessary to support canyon, tank farm, and restoration cleanup operations.

The Saltstone Facility provides the capability to treat and and dispose of nixed low-level salt solution from other facilities. The Saltstone Facility converts the waste to grout and disposes of the grout in concrete vaults. On average, Saltstone processes $4,000,000$ gallons of waste annually. Additional Saltstone vaults or alternatives will be constructed as required. Operations will end when all low-level salt solution has been stabilized and hardened in the vaults.

\section{natural resource management}

The SRS natural resources mission is to maintain excellence in natural resource stewardship; continue recognition of SRS as a national leader in resource management, research, and science literacy; and provide cost-effective, flexible, and compatible programs to support SRS missions. Over 80 percent of SRS acreage is currently under some form of natural resource management.

The site is currently restoring native vegetative communities and species, including the red-cockaded woodpecker habitat, hardwood habitat, pinesavannahs, and wetlands, in addition to protecting water quality by stabilizing soil and minimizing industrial area runoff through engineering and vegetative management techniques. Wetlands restoration at Pen Branch has recently been completed, Carolina Bays are being restored, and restoration of the site's dominant natural vegetation (longleaf pine savannahs) is proceeding where compatible with ambient soil conditions. Prescribed burning operations continue to enhance wildlife habitat, facilitate after-timber-harvest 


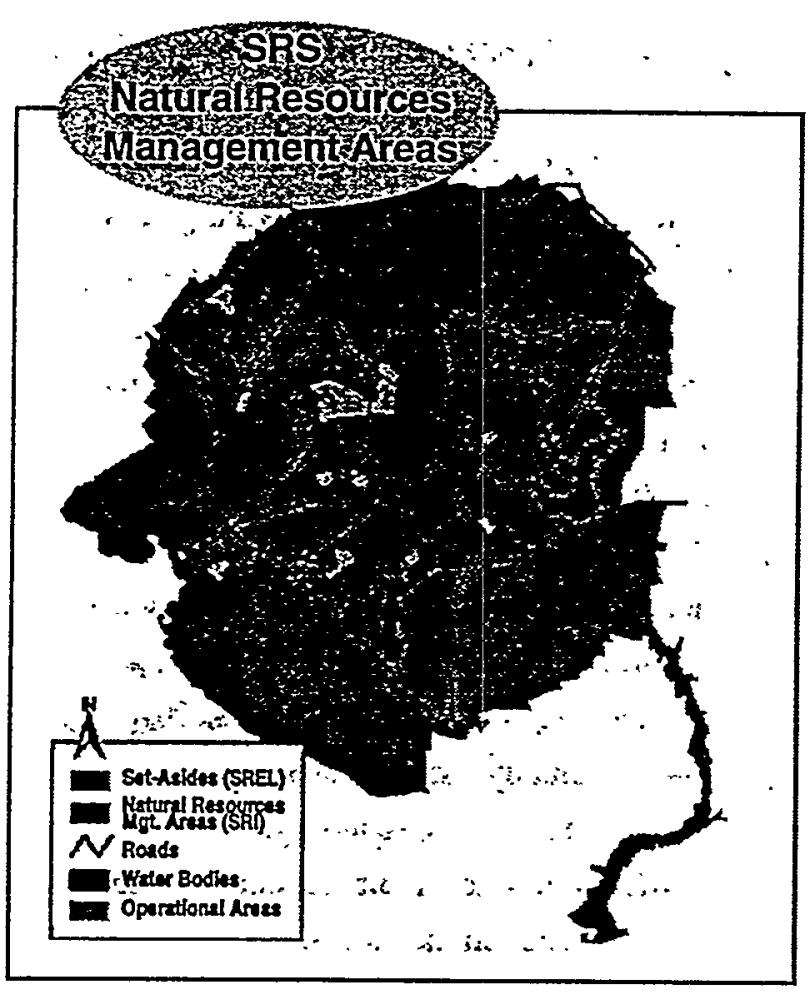

regeneration, and reduce forest fuels. Soil and watershed maintenance and stabilization provide infrastruc- . tire.support to the SRS industrial areas. Natural resource research projects cover a wide range of topical areas, including short rotation woody crops (i.e., fuel wood biomass); biodiversity, (e.g., the role of large woody debris and its relationship to wildlife food sources); prescribed fire and smoke management; wetland, pine savannah, and hardwood restoration; and endangered species recovery.

Timber production will continue to provide revenue to DOE to support the SRS natural resource program. Currently, timber sales average 25 million board feet per year. FY1997 timber receipts returned to the U.S. Treasury totaled almost $\$ 4$ million. The site's supply of saw timber is expected to increase in value because of the site's prime location for winter harvesting, proximity to local mills, and the recent overcutting trend within South Carolina. Within the next 50 years, SRS forested lands will increasingly consist of acreage (especially:hardwoods) designated for uses other than timber production: However, revenues from timber purchases are expected to increase in real dollar terms as larger diameter trees are offered to the market, and special forest products (e.g., aromatics, pine straw, forest botanicals, and floral products) become greater income producers.

The site's significance as a large-scale facility available for wildlife management and research activities is expected to increase. Economic development and increasing population migration to the southeastern United States will continue to increase pressure on wildlife species. SRS will also remain a desirable location for landscape scale studies and externally funded studies conducted as a part of the National Environmental Research Park (NERP).

Public use of the site's natural resources is presently limited to controlled hunts and to various science literacy programs encompassing elementary through graduate school levels. However, trends in population migration to the Southeast and increasing interest in outdoor recreational activities indicate that public pressure for onsite dispersed recreation use such as hiking and birding could increase.

\section{environmental restoration}

The goal of the SRS ER program is to investigate, and if needed, remediate releases of hazardous substances to minimize or eliminate potential risks to human health or the environment. SRS personnel began inventorying waste units in 1981 and identified 477 waste and groundwater units. Waste sites range in size from a few square feet to tens of acres and include basins, pits, piles, burial grounds, landfills, tanks and groundwater contamination. Soils, groundwater, and surface water have been contaminated with radionuclides and hazardous chemicals as a result of 40 years of site operations; however, most of the contamination is limited to local areas and does not pose risks to offsite receptors.

Remediation of waste sites is regulated under the RCRA and the Comprehensive Environmental Re- 
sponse, Compensation, and Liability Act (CERCLA). In 1993, SRS entered into a Federal Facility Agreement (FFA) with the Environimental Protection Agency (EPA) and the SCDHEC.to ensure that the environmental impacts associated with past and present activities at the site were thoroughly investigated, and that appropriate corrective/remedial action would be taken to protect public health and welfare and the environment. SRS is also assessing and cleaning up parts of the site consistent with the SRS RCRA Permit and settlement agreements with the SCDHEC.

As contaminated operational facilities are no longer needed, measures are being taken to reduce both the occupational risk and radiation exposure to SRS personnel and to prevent potential release of substances into the environment. At the time of this plan, 56 waste units had been remediated or were actively being remediated, six groundwater systems were in operation, 280 of the 500 total acres requiring remediation had been or were in remediation, and 150 waste units had been proposed as or granted No Fur-: ther Action status. Also, over 3 billion gallons of groundwater had been treated, with more than 500,000 pounds of organic compounds removed. Current projections anticipate that, by the year 2017, remediation for all low, medium, and high risk release sites will be complete. Under the National Contingency Plan, the SRS Natural Resources Trustee Council (consisting of DOE and seven other state and federal entities) assists with certain ER-related activities impacting the site's natural resources.

Institutional controls are legally enforceable measures or actions that may be used to supplement engineering controls to prevent or limit exposure to contaminants at a site to ensure protection of human health. Institutional controls may be applied to limit or prevent exposures to contaminants and to ensure that selected land uses are maintained. The advantage of these administrative mechanisms is that they can be employed to provide flexibility in the risk decision- making process. Institutional controls also mitigate health risks by physically restricting land use at a site. These controls may include fences, security guards, warning signs, deed restrictions, and land-use restrictions. Institutional controls do not involve reduction of the toxicity, volume, or mobility of hazardous wastes; however, they may be used in conjunction with actions that do involve such reductions. This plan constitutes an institutional control in that it formalizes policies and direction for future site land use and development. The CERCLA National Contingency Plan authorizes the use of institutionall controls based on a recognition of these and other factors.

\section{surplus facilities disposition}

The near-term objective of the SRS surplus facilities disposition activities is to establish a comprehensive, cost-effective approach to reducing residual risks and safely maintaining excess facilities until decommissioning funds can be made available or specific reuse is established. A brief discussion is provided here; additional details will be addressed in the Facilities Plan, to be developéd later: : *

Facilities are declared excess and disposition is initiated immediately when operating missions for which the facility was designed are compileted. Excess facilities are available for reuse at any of the three phases (deactivation, surveillance and maintenance, and decommissioning) of the disposition process. During deactivation, the "end points" for each facility are determined. If there are no plans to reuse the facility, surveillance and maintenance status is the low cost, safe "default" condition. If there is a future-use goal for the facility, the end points and surveillance and maintenance plan should reflect the additional work scope and cost to retain the facility in a safe condition for this option.

Immediately following the decommissioning phase, the general facility area (soil and body of water, if applicable) are evaluated to determine if there 

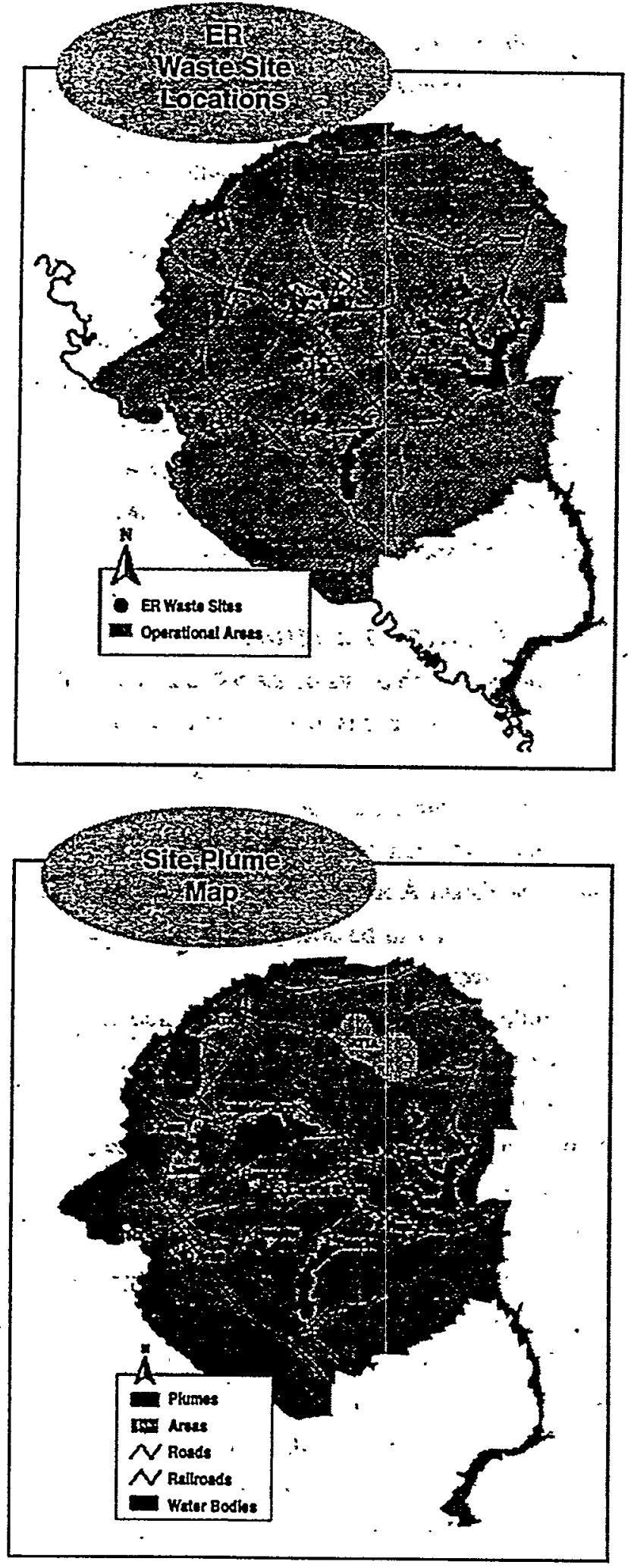

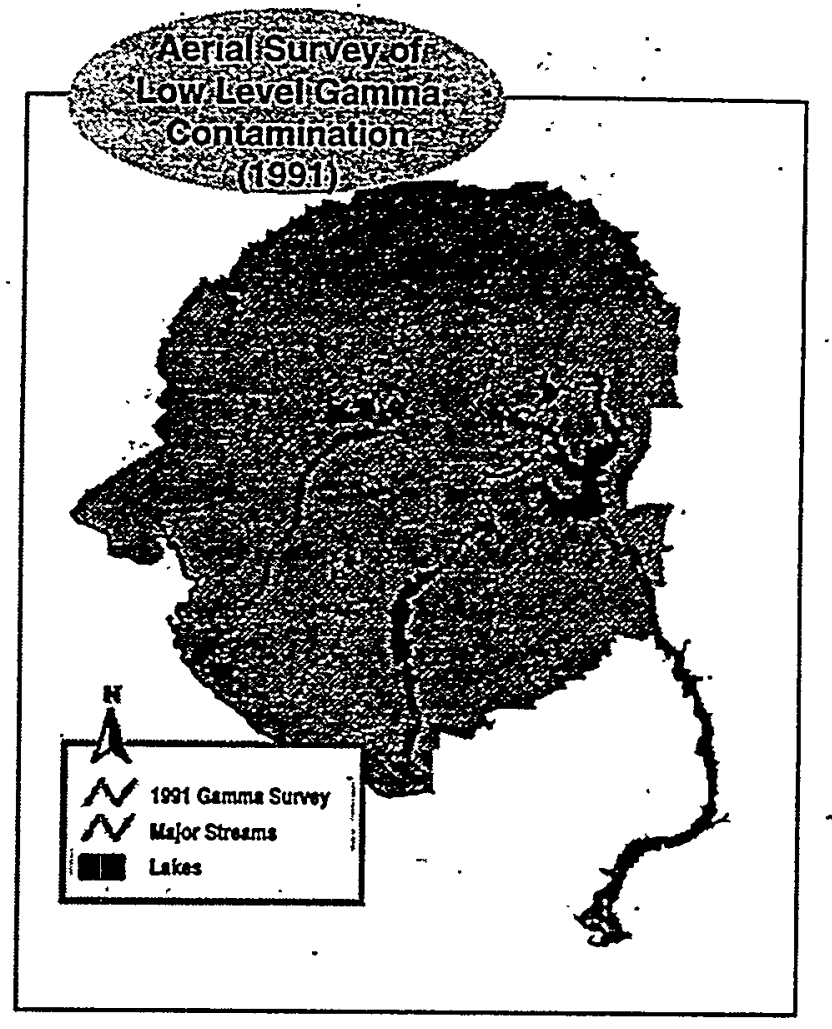


were any radioactive or hazardous material releases to the environment. If a release is detected, the area will be included in the ER Program. If no release is detected, the area will be freed for use and returned to the appropriate area manager or cognizant site organization.

\section{science and technology}

The goal of SRS science and technology activities is to deliver scientific solutions through technology innovations critical to the success of SRS missions and the science base of the DOE Complex. Unique to this area is the diversity of organizations contributing to achieving the site's science and technology goals.

The Savannah River Technology Center has established a strong reputation and performance record as evidenced by the development of core competencies for waste processing; environmental remediation; transport and diffusion of radioactive materials through the environment; nonproliferation and safeguards; instruments and sensors; aluminum-clad reactor fuel; remote systems; tritium/hydrogen; vitrification; and actinide processing. The Savannah River Ecology Laboratory bridges the gap between basic and applied science in support of SRS missions and operations. Research into fundamental aspects of ecological and environmental sciences, fate and effects of con.taminants in the environment, and the basic biology of native species provides the foundation necessary to improve both remediation and restoration activities as well as to enhance management of natural resources.

The Savannah River Natural Resource Management and Research Institute conducts research in direct support of endangered species and ecological restoration programs to provide the scientific basis for managing natural resources and other land uses in a mission-compatible manner.

Capabilities are available to conduct large-scale landscape manipulations that both enhance natural resource management and provide unique field site opportunities that attract university and industrial partners. The University of South Carolina Savannah River Archaeological Research Program studies the archaeological history of SRS and provides compliance with federal regulations governing cultural resources and antiquities: In addition to research, SRS science and technology organizations have a strong education mission, striving to improve science education and literacy and educational opportunities for diverse groups.

As SRS moves from production of strategic nuclear materials to stewardship of the remaining nuclear capability, increasing nonproliferation efforts, and environmental cleanup, new missions and requirements are created that necessitate the development and deployment of new technologies. To maintain core competericies, SRS has expanded its customer base to include offsite customers. The site is capitalizing on its NERP status to ènhance international and domestic research partnerships and is increasing granting opportunities through enhanced and expanding relationships with university and industrial partners. As funding declines within DOE overall, opportunities for support of research and education programs may decline as well; however, increases in grants or partnerships would enable continued program support."

Maintaining the SRS scientific core competencies requires sufficient funding to suppoit the critical staffing resources and the infrastructure and equipment necessary to perform needed research and development activities. In this regard, an approach has been developed to preserve the future of the multi-purpose pilot campus (formerly known as TNX). A Request for Proposals has been released to the commercial market to solicit vendors to manage these facilities for DOE under a privatized operating concept. 


\section{infrastructure}

Infrastructure provides the facilities, equipment, and operations necessary to ensure present and future SRS missions are carried out in a safe, environmentally sound, and reliable manner. Infrastructure services include those necessary to meet environmental, safety, and health objectives such as medical capabilities, environmental sampling, equipment procurement/maintenance, and emergency response. Infrastructure includes telecommunications, computing, utilities, water impoundments, transportation, materials management, central maintenance, and analytical laboratories. In addition, infrastructure organizations provide SRS. with direct program support functions based on related and similar services customized to meet unique program needs such as process computer systems, HVAC, power supplies, portable equipment, and rigging and hoisting. Future infrastructure will be addressed in greater detail in the infrastruc- ture plan. 


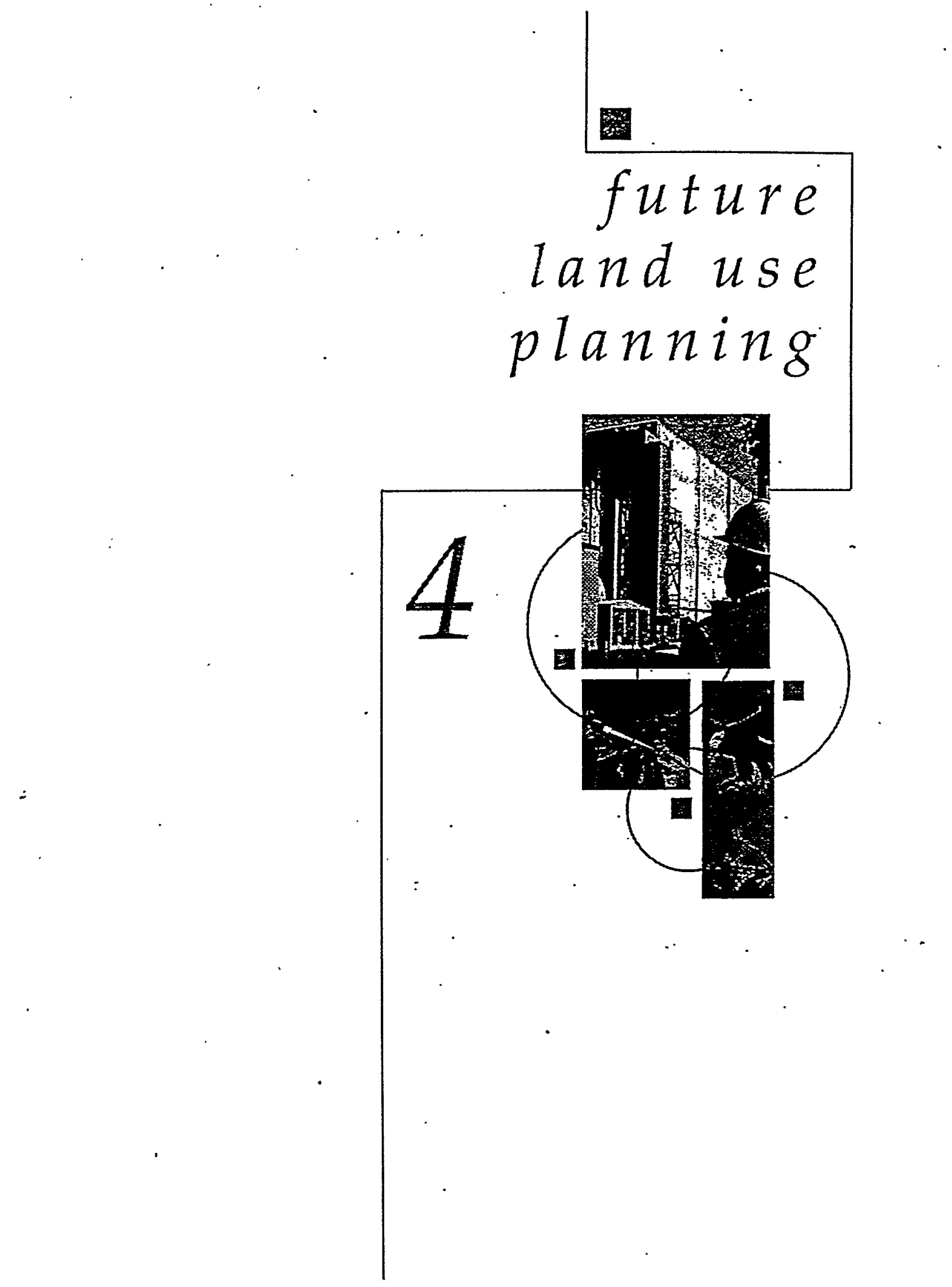


The Savannah River Site's (SRS) future use policy, goals, and objectives are the result of significant efforts over the past several years, involving extensive internal and external stakeholder participation (e.g., the January 1996 SRS "Future Use Project Report: Stakeholder Recommendations for SRS Land and Facilities").

The objective of the SRS Future Use Policy is to ensure consistent future use and development of site land and facilities so that SRS remains a vital national asset. In making land use decisions, SRS management will ensure that governmental needs are met for ongoing and new national security, nonproliferation, and environmental quality missions. SRS personnel will use a disciplined comprehensive planning process (a formal site procedure) and develop a future-use plan with designated zoning maps to guide land and facility use decisions. The objective is to ensure land/facility planning and decisions appropriately involve the stakeholders; are integrated with the strategic planning, budget formulation and execution processes; promote cost-ef-.. fectiveness and efficiency; and ensure protection of the environment. The following guidelines will be considered to the greatest extent possible in determining future land and facility use at SRS: .

- Protection and safety of SRS workers and the public shall be a priority.

- The integrity of site security shall be maintained. Appropriate institutional controls, including environmental monitoring, should be preserved.

- Future-use planning shall consider the full range of worker, public, and environmental risks, benefits, and cost.

- Buffer zones shall be considered when siting facilities.

\section{$\frac{\mid}{\text { future }}$ land use planning}

- Hazardous and radiological facilities should be located to minimize impact to environmentally sensitive areas or areas outside the SRS boundary. - A "restricted use" program shall be developed and followed for special areas (e.g., Comprehensive Environmental Response, Compensation and $\mathrm{Li}$ ability Act [CERCLA] and Resource Conservation and Recovery Act [RCRA] regulated units, as needed).

- SRS boundaries shall remain unchanged, and the land shall remain under the ownership of the federal government consistent with the site's designation as a National Environmental Research Park - Site missions will receive priority over other uses. - SRS Iand should be available for multiple use whenever appropriate and non-conflicting.

- Some land should be designated for continued nuclear and non-nuclear industrial uses, and commercial industrialization should be considered.

- Natural resources shall be protected and managed with biodiversity being a primary goal. Disturbance of undeveloped land and valuable ecological habitats shall be minimized. Research set-asides should be maintained.

- Existing infrastructure and facilities shall be considered for reuse prior to development of new sites. 
Surplus facilities without reuse potential should be placed in a safe configuration.

- Land use will be compatible with the attributes of the land and adjoining processes. The cumulative environmental impacts of existing and newly proposed uses shall be considered. .

- Residential uses of all SRS land shall be prohibited.

- Industrial and environmental research and technology development and transfer should be expanded.

- Recreational opportunities should be considered and increased as appropriate.

\section{future use \\ assumptions.}

A number of assumptions will guide the future development and use of SRS land and facilities. These have been developed with significant input from internal and external stakeholders over the past several years. As set forth in the SRS Strategic Plan, primary planning assumptions include:

- Federal ownership of SRS will continue, and site

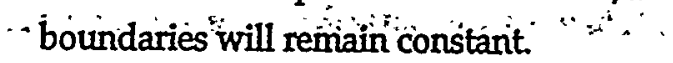

- Risk reduction will be a key driver for work prioritization decisions within constrained budgetsiand staffing.

- Efficiency improvements will continue to contribute to overall mission success of SRS.

- Offsite national repositories will be available for permanent disposal of nuclear waste.

- A number of DOE's prior weapons sites will be successfully closed, and consolidation of nuclear materials will occur.

- National and international commitments will increase emphasis on disposition of surplus nuclear materials.

- Site facilities will be available to meet the nation's nonproliferation needs.
- Uncertainties in site staffing levels and funding pressures will continue.

- Regulatory requirements and Defense Nuclear Facilities Safety Board recommendations will be met.

\section{future use \\ planning considerations}

\section{land use considerations}

The land-use plarining process at SRS includes a number of evaluation criteria that are considered when new missions are analyzed, new land uses are proposed, or new facilities are sited. Some of these criteria are exclusionary in nature for all potential future uses; whereas, others are specific to a particular use. Criteria that generally are exclusionary for facility siting, but notriecessarily for other potential uses, include threatened or endangered (T\&E) species, research SetAside areas, Category I wetlands and streams, known waste sites, the 100-year floodplain, or the prior reser'vation of an area for some future use.

Other factors that generally are considered and weighted to determine the optimal site for a new land use include existing land use at that site, if any; ecological considerations such as distance to streams and other wetlands, distance to threatened, endangered, and sensitive species, and distance to Set-Aside areas; geological considerations such as depth to groundwater, soil stability, faults, and slope; engineering considerations such as distance to roads, rail lines, and existing utilities, likelihood of archaeological deposits, terrain, and distance to existing waste sites; and security and human health considerations such as distance to the site boundary, distance to other facilities, and the security requirements of a new land use.

Threatened and Endangered Species. SRS provides habitat for four federally endangered species (red-cockaded woodpecker, wood stork, shortnose 
sturgeon, smooth purple coneflower) and two federally threatened species (bald eagle and American alligator). Current and future land use in the immediate. vicinity of federally threatened or endangered species is limited. Other species that require consideration because they are state listed, or may be federally listed in the future, include the gopher tortoise, Carolina gopher frog, pine snake, and southern hognose snake. Future protection may also be required for neotropical songbirds, whose populations have declined significantly nationwide in recent years. Although no neotropicals presently are federaily listed, several are listed as priority species for protection by the state of South Carolina.

Within the next 25 years SRS can expect more T\&E species, either as a result of new on-site discoveries or as a result of additional listings at the federal and state levels. At the same time there will be more federal and state flexibility in regulation of species recovery programs: The site T\&E management will need to be closely monitored for impacts on neighboring landowners. There will be an increased need for and opportunities to establish cooperative recovery and man-. agement ventures with private entities and other governmentagericies. Federal installationssuch as SRS will be expected to be more proactive in species protection rather than merely achieving minimal regulatory compliarice.

Set-Aside Areas. Set-Aside areas fulfill a directive of the National Environmental Research Park (NERP) by setting aside relatively unimpacted areas for assessment and monitoring purposes.

The protection and management philosophy for the SRS Set-Aside areas states that they:

- are for research, not for intensive management objectives.

- should receive as little management as possible.

- should be protected to remain as natural as possible with little or no human influence.

- are primarily for non-manipulative research. No

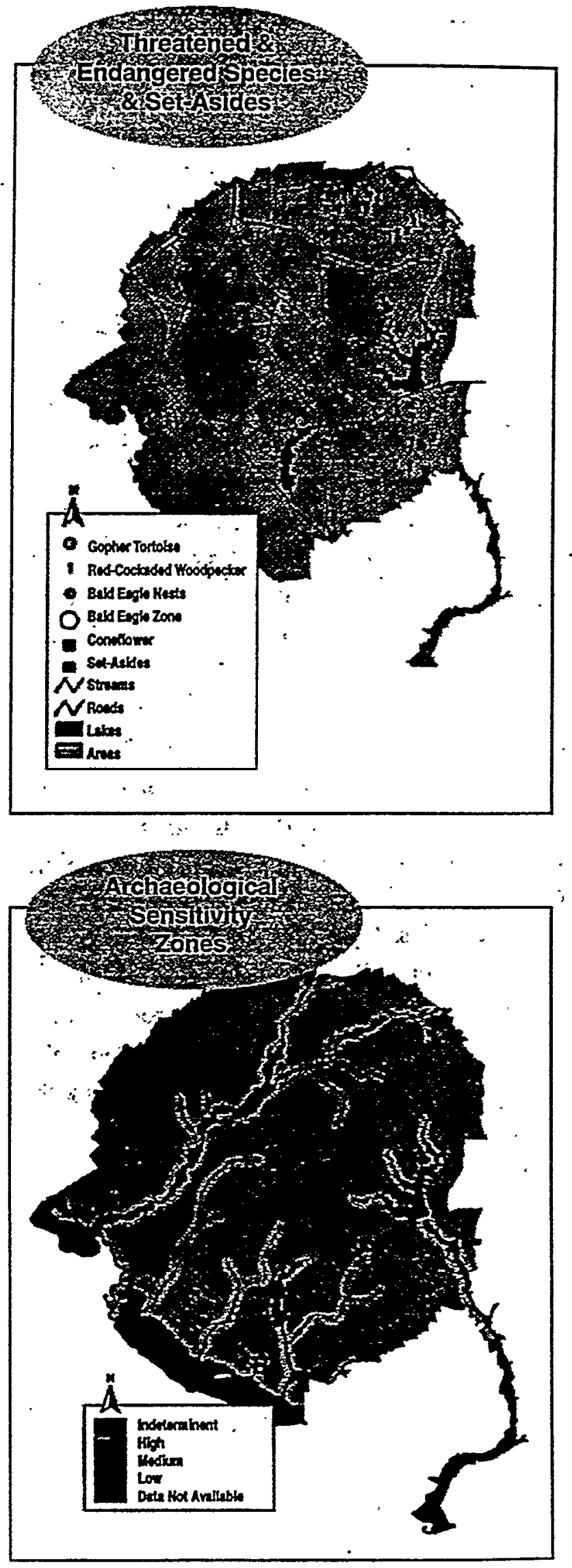


research should be conducted on a Set-Aside area that would alter the long-term value of the Set-Aside.

The 30 DOE research Set-Aside areas are excluded from most routine site maintenance and forest management activities. Theseareas were established to represent all of the major habitat types on SRS and to provide sites for long-term ecological research. These areas also function as control areas', in evaluations of the effects of SRS operations and forest management activities on other regions of the site. The largest is the E. P. Odom Wetland Set-Aside, which includes the northern section of the Upper Three Runs watershed, and is specifically protected by the SRS Stream Management Policy. The 30 Set-Asides comprise 14,005 acres, or about seven percent of the total area of SRS. Habitats represented by the Set-Asides include oldfields, sandhills, upland hardwoods, mixed pine/hardwoods, bottomland forests, swamp forests, Carolina bays, and fresh water streams and impoundments.

Category I Wetlands and Streams. Category I resources are defined by the Department of Interior as unique and irreplaceable on a national basis or in the eco-region. At SRS, this definition includes Carolina bays and cypress-tupelo swamp because of the limited number of undisturbed habitats of that type occurring elsewhere in the region. In addition, any habitat that may support a species of concern would also be considered an unique or irreplaceable. Areas of the site contäining high-quality wetlands or headwater streams, particularly the upper reaches of Upper Three Runs, would also be considered for Category I status. Any planring or site selection process for future use at SRS must consider Category' I resources and avoid impact to those areas.

100-Year Floodplain. Although new facilities will not be located within the 100-year floodplain, land within the floodplain is available for other types of future land use on SRS. Many of these areas currently are and will continue to be sites of ecological research; future expansion of recreational activities on SRS likely will occur in some of these areas.

Seismology. Studies of the underlying geology of the site indicate the existence of several faults, including the Pen Branch, Steel Creek, Advanced Tactical Training Area, Ellenton, Crackerneck, and Upper Three Runs faults. Although none of these faults are thought to be capable of generating significant earthquakes, the presence of faults are considered in proposed future use evaluations.

Contaminated Areas. SRS manages waste units under the Resource Conservation and Recovery Act (RCRA), which governs hazardous waste and constituents in regulated and nonregulated units. The site has also been placed on the Comprehensive Environmental Response, Compensation and Liability Act (CERCLA) National Priority List. Regulatory requirements dictate the remediation of hazardous substance releases and of inactive hazardous waste disposal sites. To date, approximately 477.SRS areas have been identified as potential waste units. Evaluation of these units and remedial actions (if required) are under way based upon schedules in the Federal.Facilities Agreement. Although designation as contaminated does not automatically eliminate an area from consideration for future use, future use of contaminated areas will be dependent upon the proposed land use; the nature of the contamination, and the estimated costs of any required remediation.

\section{community issues}

Environmental Justice. Executive Order 12898, "Federal Actions to Address Environmental Justice in Minority Populations and Low-Income Populations," (February 11, 1994) requires that federal agencies "identify and address disproportionately high and adverse human health effects of their programs, policies, and activities, on minority populations and low-income populations." The site is addressing environmental justice concerns in conjunction with public participation 

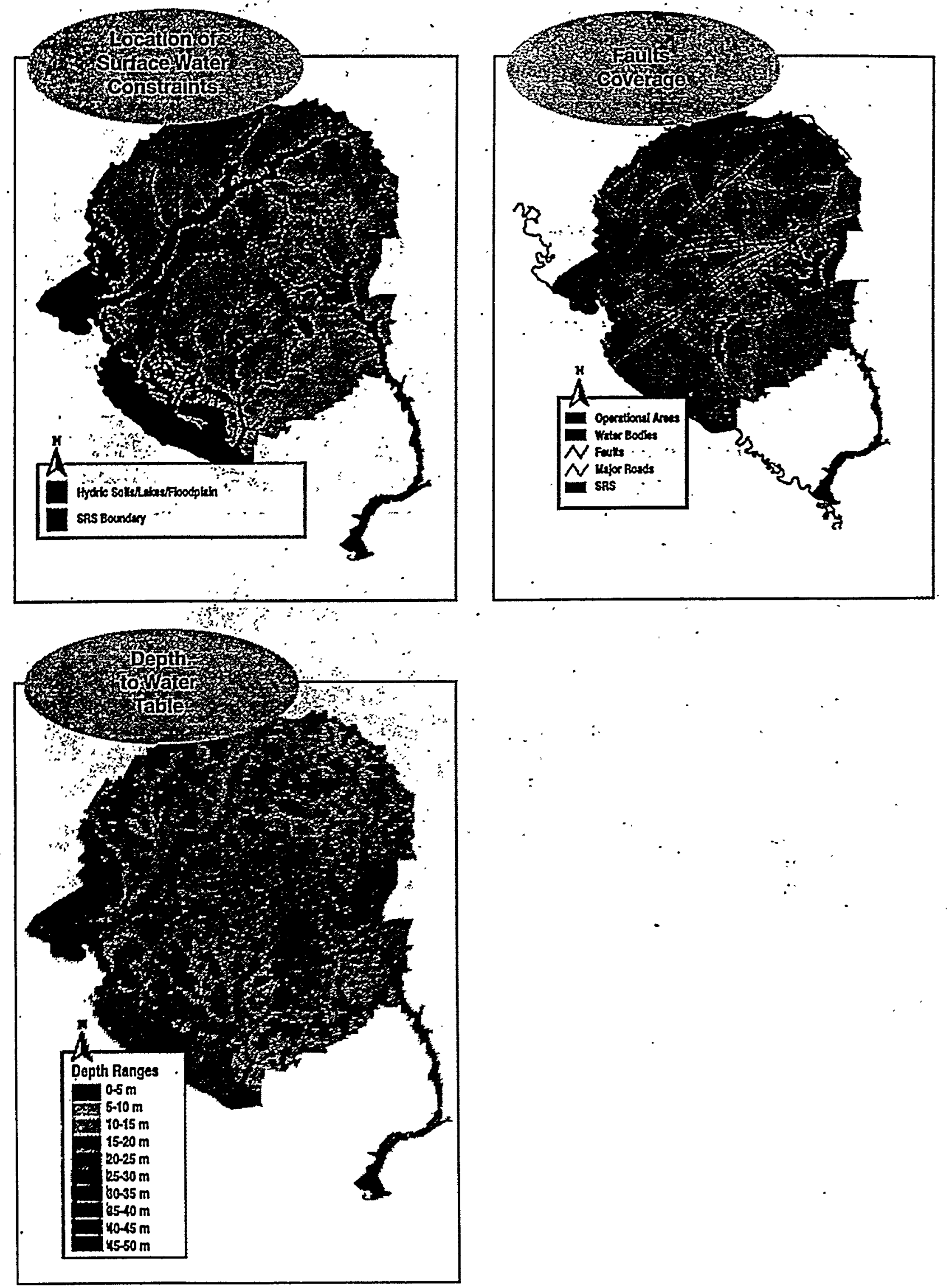
for site planning, locating new facilities, environmental remediation decisions, and other site activities.

Community Alliances and Economic Development. In addition to its primary national security and environmental management missions, SRS has played an important economic role for the region and the nation during the last four and a half decades. SRS infuses more than $\$ 1$ billion annually into the economies of South Carolina and Georgia, provides thousands of jobs, conducts environmental and advanced technology research, and supports business development initiatives with local communities.

The nature of SRS operations requires restricted or even prohibited access to certain areas, but many site buildings are outside fenced areas. Safety, efficiency, responsibility, security, and openness are top site priorities. DOE as a whole has a significantly better safety record than private industry, and SRS leads the Complex. Public awareness and community outreach programs offer seminars, meetings, exhibitions, . and site tours on a regular basis to educate the people about nuclear technology and environmental issues. Many commanity groups such as the SRS Citizens Advisory Board, Savannah River Regional Diversification Initiative, Citizens for Nuclear Technology Awareness, chambers of commerce, and economic development organizations provide guidance and feedback in designing policies and programs.

The DOE Complex-wide downsizing initiatives have resûtted in a continuous decline in site employment since 1992. From September 1991 to April 1997, the site workforce was reduced by more than 40 percent. But, the impact of the SRS workforce extends beyond the jobs that are provided directly or indirectly in the region. The site also contributes significantly toward improving the talent base and citizen involvement of surrounding communities. SRS employees contribute financial resources as well as time to civic activities and are actively involved in local politics. During 1996, site employees also contributed \$1.8 mil-

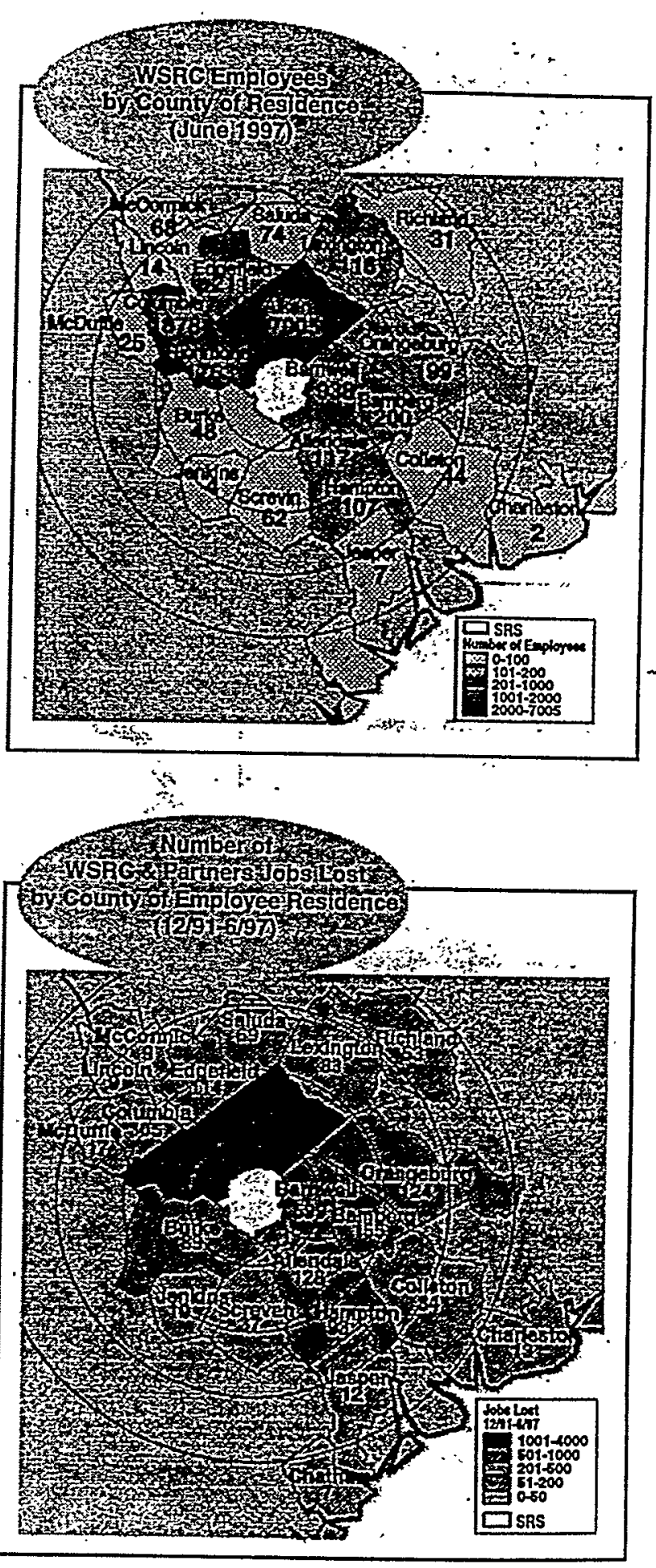


lion to the United Way charities, donated more than 20,000 pounds of food, and gave 3,000 units of blood.

SRS also contributes to economic development in South Carolina and Georgia through a number of special programs. These programs support educational, research, and business development activities in the two states. In addition, $\mathrm{SRS}$ provides direct assistance to various community initiatives in the region. During the last five years, SRS has undertaken several programs to help local communities diversify their economic base. The main purpose of these programs is to minimize the economic impact to the region as a result of SRS downsizing by helping the local communities generate alternative sources of employment.

The site's business development and community assistance organizations have implemented several programs to spur job creation and economic development in the region. Activities include privatizing nonclassified SRS operations; transferring technology for commercial use; providing funds for building infrastructure; selling surplus equipment; providing technical assistance to economic development initiatives; and networking with community organizations.

\section{hazards and risks}

The term "risk" is used frequently in future-use planning. However, because of its recent widespread use, the term "risk" can be confusing and should be defined in context prior to its. use. In the future-use circumstance, risk means the danger of a hazard causing injury to humans and/or the environment. Questions arise as to the risk of public contamination and resultant injury or illness and risk of major or irreparable harm to the environment:

Identification of hazards does not mean that an area is unusable. It means that plans should consider the range of risks from hazards when preparing for the future. Assessing risk allows the decision-making process to compare alternative land use planning actions through their compatibility with higher level planning goals, and choose those that are most likely to achieve overall planning success. Many areas of SRS still have beneficial land uses even though they may be unfit for residential use (e.g., industrial uses, limited recreation or research).

As clean-up technology improves or as new risks or new contaminants are discovered, these factors feed back into the dynamic planning process, leading to additional considerations which could result in changes in future use plans.

\section{multiple uses of srs land}

The multiple-use concept allows for compatible concurrent land uses, normally on large tracts of land. The most difficult aspect of multiple use planning is determining compatibility. However, through its newly initiated comprehensive planning process, the site has. already demonstrated the ability to accommodate multiple uses on much of its land area. Many stakeholders are interested in continuing, if not expanding, this multiple-use concept. Members of the public have mentioned the site's status as the first National Environmental Research Park and expressed a desire to continue or expand the opportunities inherent in that designation. Those opportunities include co-location of industrial, ecological, resource management, and recreational activities within limitations of health, safety, and security. Given the site's size and diversity of programs, multiple uses are stressed in developing future land-use options. 


\section{Future Land Use Map}

- The Future Land Üse Map shows the industriaiized areas of SRS, including appropriate buffer zones. This map reflects the agreement with stakeholders and regulators as documented in the Federal Facilities Agreement Implementation Plan.

Institutional control remedies have been identified in Records of Decision for a number of waste sites where infrastructure is reeded to secure a site for future safety and health protection of employees or the public. Examples of such sites are the F- and D-Area Isolated Hazardous Materials Units, Silverton Road Waste Site and the Old F-Area Seepage Basin. Some of these sites fall into the current industrial zones and some do not. Where these sites occur outside of existing industrial areas, the reasonably anticipated future use of the land is considered in reaching cleanup decisions. Consistent with stakeholder input, residential use of any part of SRS is not intended nor anticipated. 


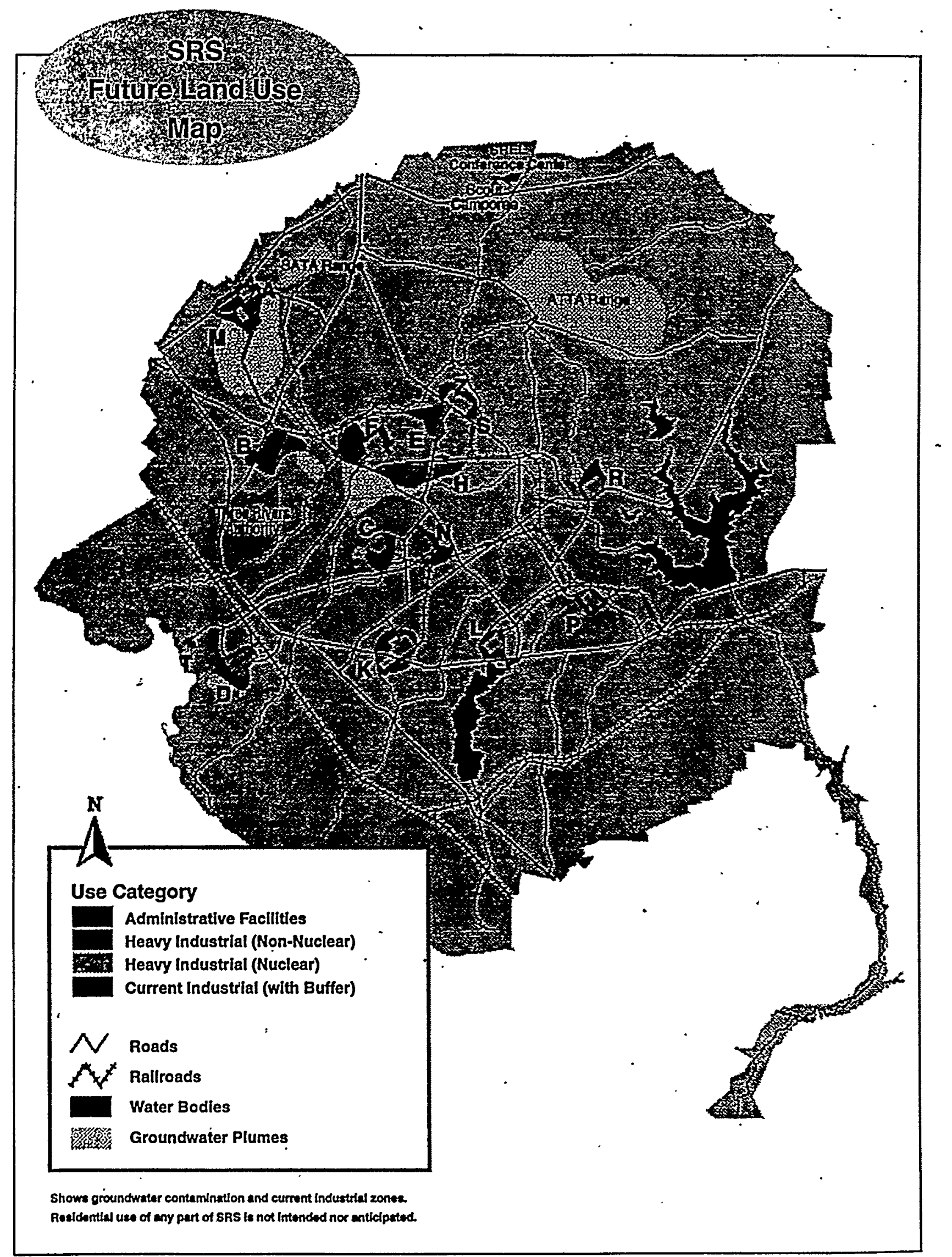




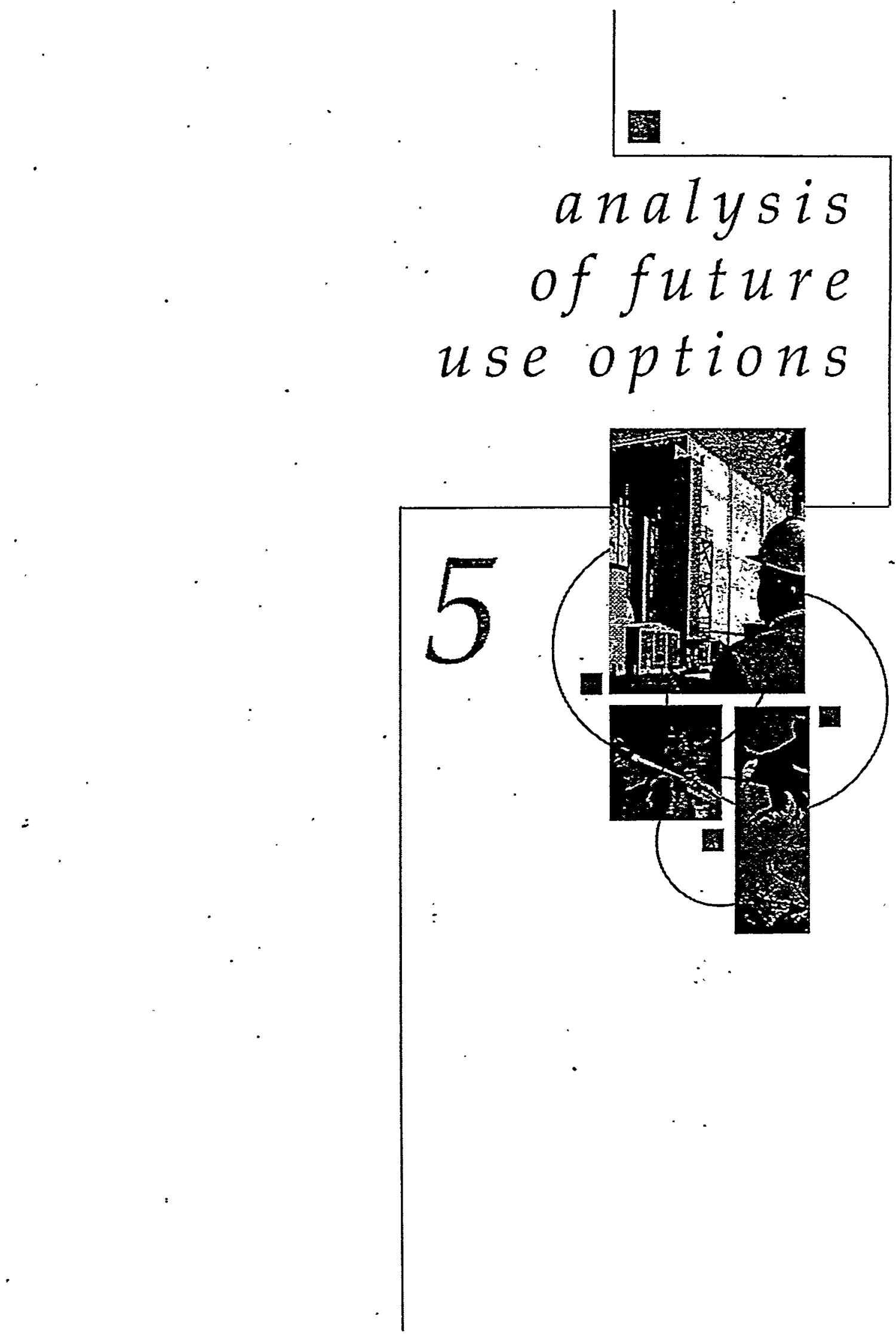


"The criteria for analyzing future use options were designed to ensure that the chosen option would be flexible enough to accommodate current and future mission needs while protecting the environment and the safety and health of employees and the public, By selecting the Integral Site Model and the zoned planning concept detailed in Section 6 , the Savannah River Site (SRS) met these criteria and has also ensured that the future use policy and guidelines'set forth in the Future Land Use planning section of this plan are an integral part of the planning process and future land use decisions (e.g., considering the full range of worker, public, and environmental risks, benefits, and cost; ensuring site missions receive priority over other uses; facilitating the multiple usè concept; and protecting and managing natural resources with biodiversity as a primary goal).

Some of the key elements of the referenced policies and guidelines which this model satisfy are listed as follows:

- Residential use will not be allowed.

- Federal ownership of the site will continue.

- The land will be available for multiple use.

- The site boundaries will remain unchanged.

- Cleanup of the site will be supported.

Research set-asides will be protected.

In selecting future use options for analysis, SRS used several years of input from external and internal stakeholders, site management, and Department of Energy (DOE) Headquarters to identify viable alternatives for the site's future. After public meetings, workshops, consultation' with state and federal agencies, and development of policy guidance, it was decided that four basic future use models would be evaluated: Consolidated Core, Residential, Disaggregate, and Integral Site. Each of these models is discussed on the pages that follow.

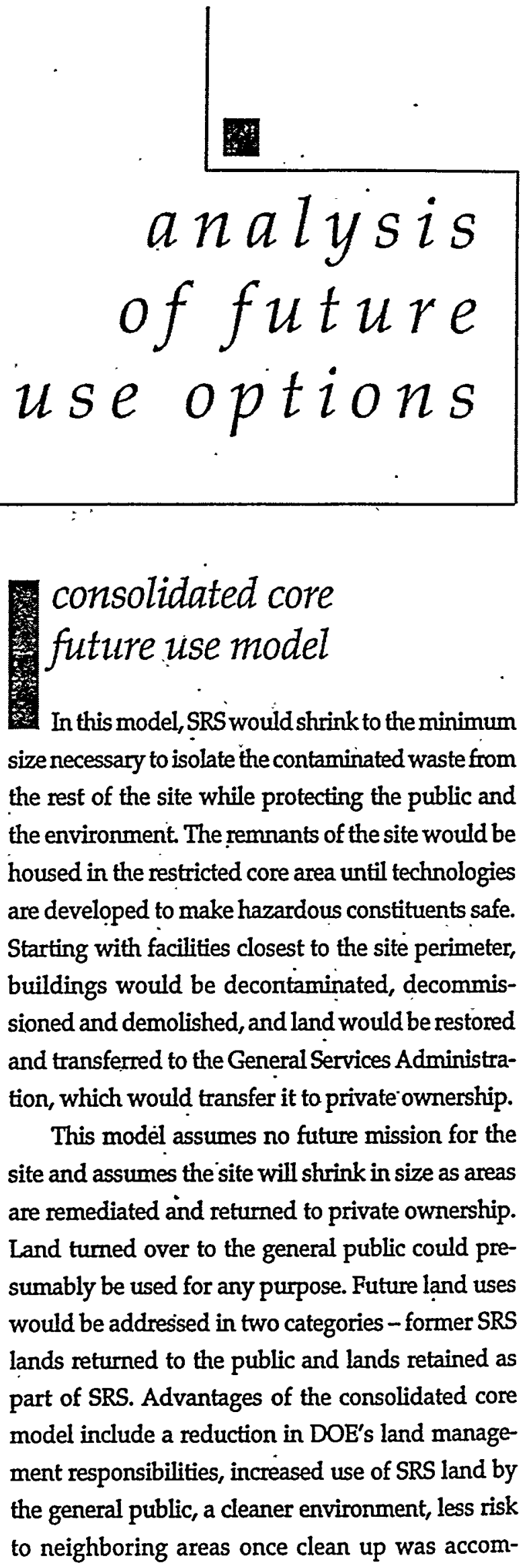


plished, and reduced operational costs after consolidation of site operations to a central core area.

The disadvantages of this model are significant, however. It is unlikely that technology or funding will be available to clean up many areas to levels adequate for unrestricted public access. Remaining waste management facilities, such as the Consolidated Incinerator Facility, are likely to require significant protective buffers that would minimize the amount of land that could be returned to surrounding communities. Without future missions at SRS, thousands of current employees would lose their jobs when clean-up was completed. Liability for future health effects resulting from exposure to SRS lands would continue to reside with DOE, requiring that any lands returned to the public be cleaned to residential standards - a considerable burden for the U.S. taxpayer. The land value based on in-lieu-of-tax payments currently made by DOE to South Carolina versus the per acre value of the land after it is clean probably would decrease and likely would àdversely impact local economies. Without an expressed desire by the general public to acquire SRS land, this scenario adds no appreciable value.

\section{residential \\ future use model \\ $\because \quad \cdot$}

This model assumes no federal mission for SRS and also assumes that the site would be cleaned up to Comprehensive Environmental Response, Compensation and Liability Act (CERCLA) standards for residential use. Restoration would include surface water, groundwater, and soils, and the land would be transferred to the General Services Administration for transfer to private ownership. Asignificant increase in budgetary allocation from Congress would be required to clean up SRS to meet Environmental Protection Agency guidelines for return of land to the public for residential purposes.
The residential scenario calls for all of SRS, except for existing waste units with clean-up decisions under CERCLA or RCRA that preclude residential use, to be returned for private use as single-family or multi-family dwellings. Associated with residential development would be shopping areas, small businesses, community areas, and schools. Other possible uses of lands classified as "residential" could include farming, hunting, and development as recreational areas. These uses could be accommodated on the 310 square miles of SRS land, with various areas possibly zoned for different uses.

Return of SRS to residential use would force DOE to clean up the site to levels required by CERCLA for residential purposes, resulting in enormous costs and a considerable time commitment. Although transfer of SRS to private control ultimately would free DOE from land management responsibilities in this region, DOE could remain responsible indefinitely for any adverse public health or environmental effects that resulted from previous site operations. Closure of SRS would result in significant loss of employment in the region, which would have detrimental impacts on the regional economy that could not be supplanted by existing industries. Additionally, return of SRS lands to private occupation would seriously threaten the extraordinary biological diversity of the site. With private ownership of SRS lands, federal control, protection, and management of a great diversity of natural and cultural resources would be lost. Residential development of SRS lands would negatively impact aquatic and terrestrial resources used by federally protected plant and animal species (e.g., smooth purple coneflower, bald eagle, red-cockaded woodpecker, wood stork, shortnose sturgeon). In addition, other species that are potential candidates for federal or state listing as "threatened" or "endangered" would be in jeopardy. Also, SRS is a major center of ecological research, and the site of some of the longest-running ecological studies in the world; these invaluable research areas would be destroyed by 
residential development.

Current waste remediation technology does not permit cost effective clean-up of the SRS to residential standards. Many waterways on the site are contaminated at low levels with various contaminants, and it probably is not feasible with current technology. to remediate these areas to standards acceptable for residential development.

Transfer of SRS lands to private ownership would leave no means to recapture 45 years of federal improvements, including $\$ 4$ million per year in timber revenues. Residential development also would negatively impact cultural and archeological resources on SRS lands. Return of SRS lands to the public for residential development would require that extensive archeological surveys be conducted, which would probably require several years and significant budget allocations to accomplish. Finally, public meetings and stakeholder recommendations have indicated that residential uses should be prohibited at SRS.

\section{disaggregate}

future use model

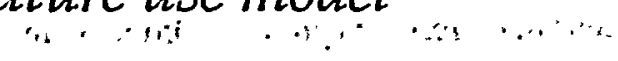

This model assumes that lands not within the site core or along contaminated stream corridors would be available for transfer to public uses. The assumed goal is a reduction in DOE holdings by about one-third to one-half. Conditions for transferwould need to address whether or not the areas are free of contamination and how sensitive site features would be protected. The Disaggregate Model would maintain a central site core to support SRS missions and retain known areas of major contamination for control by DOE. Radiating from the core would be "tentacles" of land that would be maintained by $D O E$ with restrictions on future use. The "tentacles" would generally follow site streams known to be contaminated. Site lands outside the core area and "tentacles" would potentially be available for transfer to the General Services Administration or other federal agencies. Ultimately, some or all of the lands could become available to the public resulting in a wide range of future uses.

The basic advantage of this model is that it allows for the centralization, concentration, and confinement of the site's mission-related activities to a core area. It would also retain land areas that could be potentially required during the reconfiguration and consolidation of the DOE Nuclear Weapons Complex. Implementation of this model would result in decreased security patrol of the Savannah River swamp, would allow public use of natural resources without access to core or contaminated drainage areas, and would reduce the cost of infrastructure maintenance.

However, this model also presents many challenges. Property would need to be carefully characterized prior to transfer to ensure waste sites are not accessible by the public. Issues of public health and safety could become costly and time consuming. Because of - the configuration of tentacles related to this model, site security could be more troublesome, and buffers to the public would be reduced. Site boundary dose calculations would need revision, and monitoring stations would require relocation. Expansion or realignment of the site mission may become more difficult due to encroachment of public uses on the site boundary. As a final, important impact, a significant portion of SRS would no longer be designated as a National Environmental Research Park (NERP). SRS is the first, largest, and most active NERP. The biodiversity of the site could decrease, and important research areas between . site property would likely be degraded by public access. Specific research study sites and equipment would be impacted. The level of contaminant monitoring for game species would need to increase because of reduction in the site buffer. 
integral site future use model

Of the four scenarios evaluated, the Integral Site Model is the one with the most desired outcome, based on stakeholder acceptance, monetary considerations, environmental compatibility, and local and national needs. (The next section of this plan discusses the implementation of this Future Use Model in greater detail.) Site boundaries would remain intact, and land use would not change significantly. This scenario allows for the accommodation of new missions. The amount of environmental cleanup would depend on the intended future use, but potential new missions that complement existing site uses are less likely to alter the existing land use and are also less likely to require extensive cleanup. Land uses that require extensive public access would not be compatible with this scenario.

This model includes the following assumptions:

- Environmental, forestry, wildlife, and archeological activities will continue concurrently with the pursuit of the SRS operational missions.

- Technology development and transfer will expand as the barriers between federal, state, and local governments and private industry :are eliminated.

- Surplus facilities will systematically transition from production to minimum maintenance facilities and eventually be either decontaminated and dismantled or identified for alternative missions.

- Residential uses will not be permitted in any area of the site.

- DOE funding will support limited "transition," and risk assessment will be critical to prioritizing facilities for restoration. Decontamination and decommissioning of process- contaminated facilities will be focused on those of high risk.

- SRS will be the preferred site for new missions.

- Technical expertise will be retained.

- Site infrastructure, security and other institutional controls will be maintained.

- There will be continued political support for SRS activities.

Advantages of this model include:" :

- Flexibility for planned and future missions.

- Retention of maximum buffer (safety) zones between existing and future SRS operations and the public.

- Opportunities for forest resource utilization and facilities because the large contiguous site area is maintained.

- Cost-effective remedial decisions based on - reasonable anticipated future use.

- Maximum preservation of historic, prehistoric and archeological resources, allowing continued cultural research.

- Reduction in potential liability from private ownership of land.

- Continued research and development and

retention of Set-Aside areas designated under the NERP program, which may stimulate new missions.

- Three significant environmental advantages: (1) the vast expanse of habitat would support biodiversity and species enhancement projects as well as research and monitoring activities; (2) the large abundance of wetlands increases the opportunities for research in the areas of wildlife habitat, wetlands biology, and hydrophilic vegetation; and (3) Set-Aside areas would be retained and thus promote habitat development, biodiversity, protection of endangered species, and environmental research, monitoring, and investigation. 
With regard to potential new missions, existingsite attributes that may benefit future DOE or other national programs include large buffer zones, extensive infrastructure, existing technologies and facilities, and a workforce of highly educated and skilled personnel with a wide range of experience related to these issues. With few exceptions, the existing site infrastructure complements the Integral Site Scenario, with infrastructure related to heavy industrial or nuclear land uses concentrated in the site's center, and infrastructure supporting non-industrial activities located appropriately throughout the site.

The current and future site uses discussed in "Current Situation and Future Projections" are compatible with the Integral Use Model, as is the concept of Multiple Use discussed earlier in this plan. 
-

implementation of the integral future use model

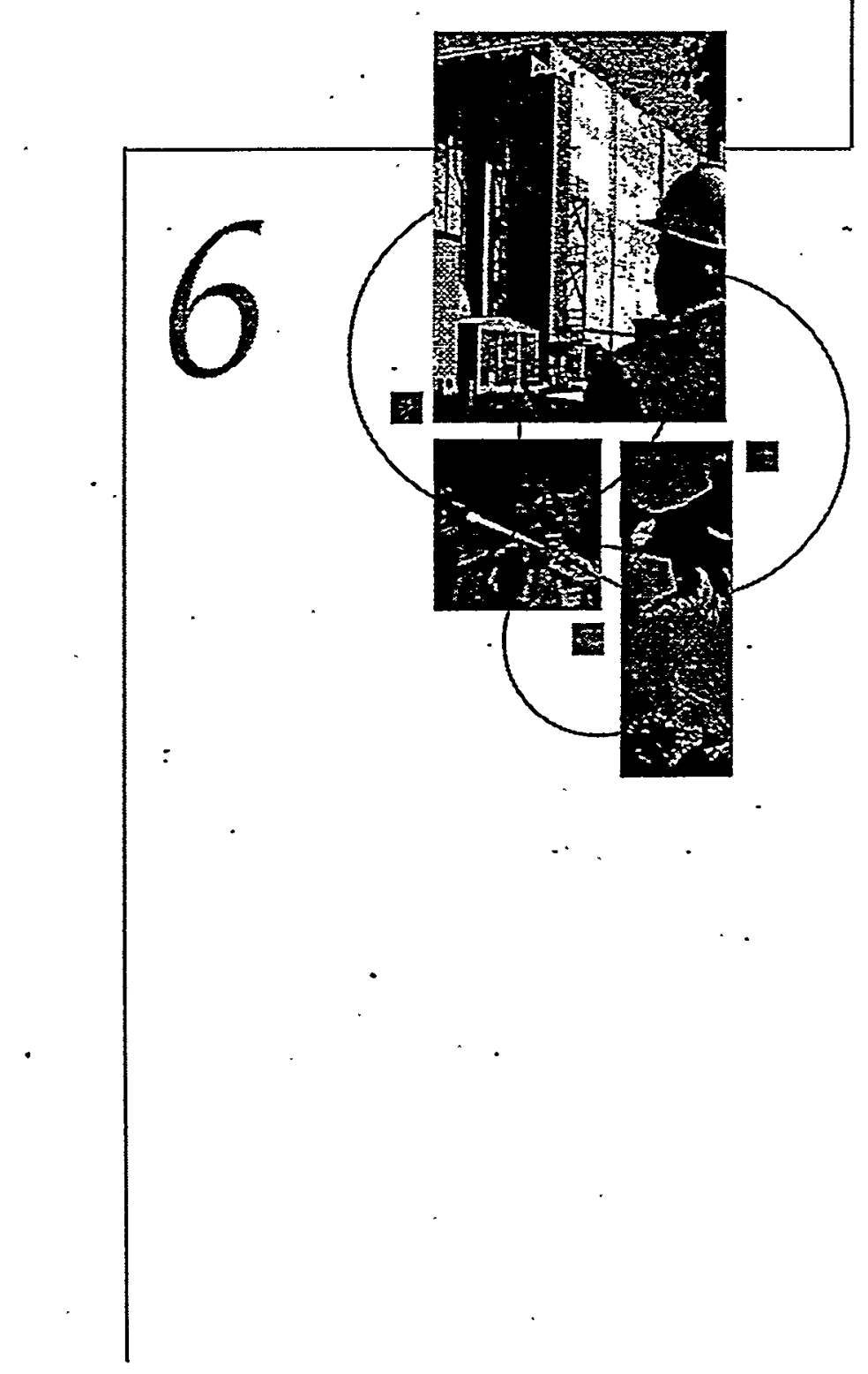


Savannah River Site (SRS) management determined that, of the four models presented in the previous section of this plan, the Integral Site Model most realistically accommodates development during the next 50 years and therefore is the approach to future-use planning.

To reiterate the key advantages of this model, it allows flexibility for planned and future missions; provides maximum buffer; allows for research, natural resource management, biological diversity and cultural maintenance; and maintains one of the larg-: est natural area expanses east of the Mississippi River.

In selecting this model and the implementation method discussed below, SRS management has strengthened its commitment to the application of the future use policy guidelines and planning considerations detailed in Section 4 of this report.

\section{implementation of the integral site future use model}

To implement the Integral Site Future Use model, SRS planners developed a zoned planning model specifically designed to address the SRS future land-use circumstances. SRS future land-use decisions will not require "either/or" determinationsrather, SRS will remain a viable site in the future through simultaneous; concurrent, compatible land use. The zoned planning concept will enable effective land-use decisions to be made under these circumstances. Using this concept, the site is divided into three principal planning zories - Industrial, Industrial Support, and Restricted Public Use. To minimize the effect on surrounding localities, maintain controlled site access, and keep the established safety buffer, the most intensive uses occur in the Indus-

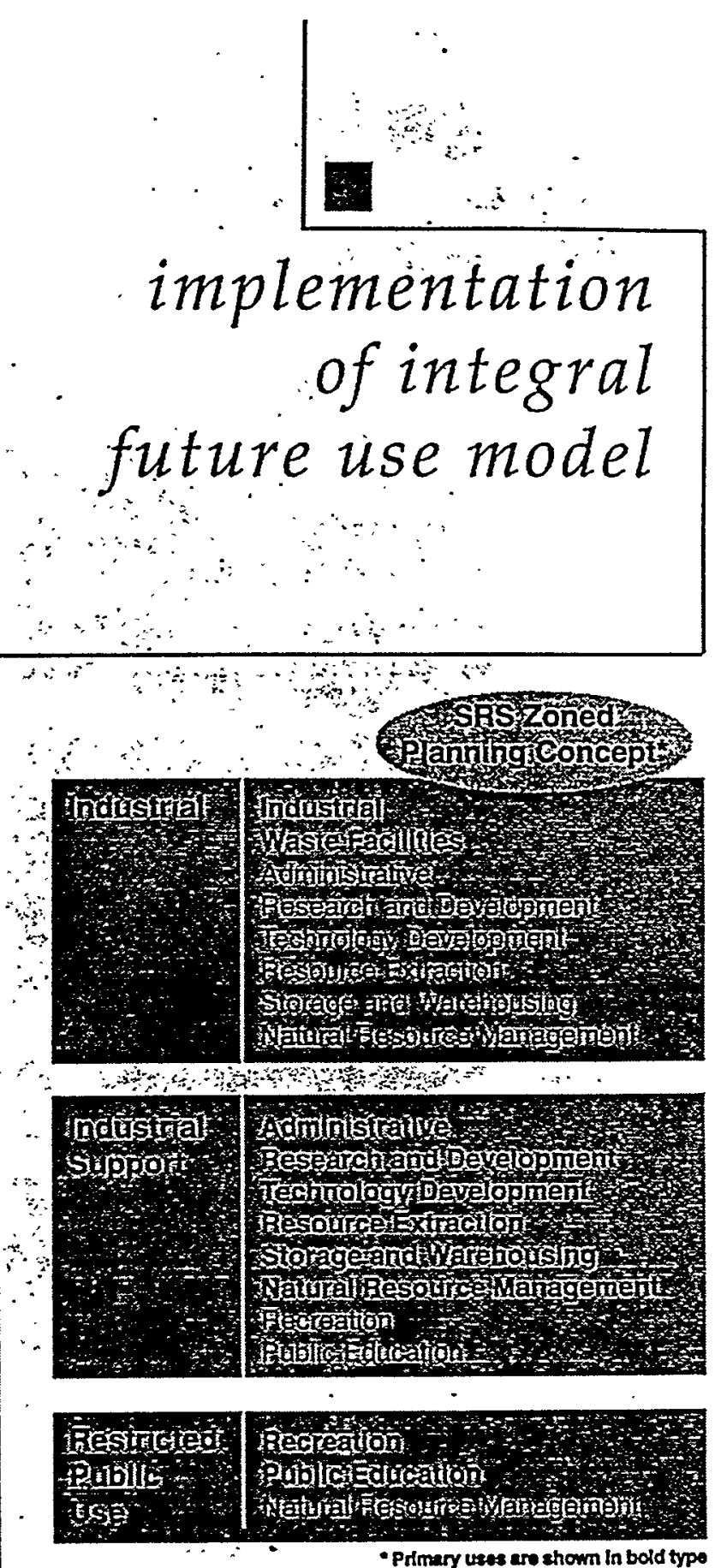

- Primary ueses ans shown In bold typo

trial zone located close to the site's center. Expanding on that concept, the Industrial Support and Restricted Public Use zones accommodate uses of decreasing intensity and are located closer to the site's boundaries. Each zone is restricted to the types of uses specified for that zone, as shown in the chart above. If conditions arise where a non-allowed use is proposed for a zone (i.e., a heavy industrial use is 




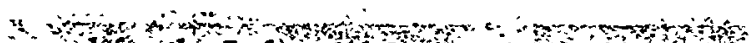
proposed for the Industrial Support zone), approval would require a zone or plan change following the process described in the Comprehensive Planning Process section of this plan. It should also be noted that residential use will not be allowed in any of the zones, and the site infrastructure, security and other institutional controls will be maintained in all the zones.

The planning process and the zoned planning concept described in this document establish direction for site development for the next 50 years. In cases where a pre-existing use is located within a zone in which it would be-considered non-conforming, it will be "grandfathered" and will continue through the life of its mission. When its mission is complete, all future uses for the area must be conforming.

As new facilities and missions are considered, the general location will be determined according to the established zones and the allowable uses within that particular zone.

Each of the zones are described on the following pages. Specific locations within a zone for proposed activities would bedetermined through the planning process as well. The planning considerations in Section 4 of this plan will be used in determining the suitability of any particular site for a proposed use. 


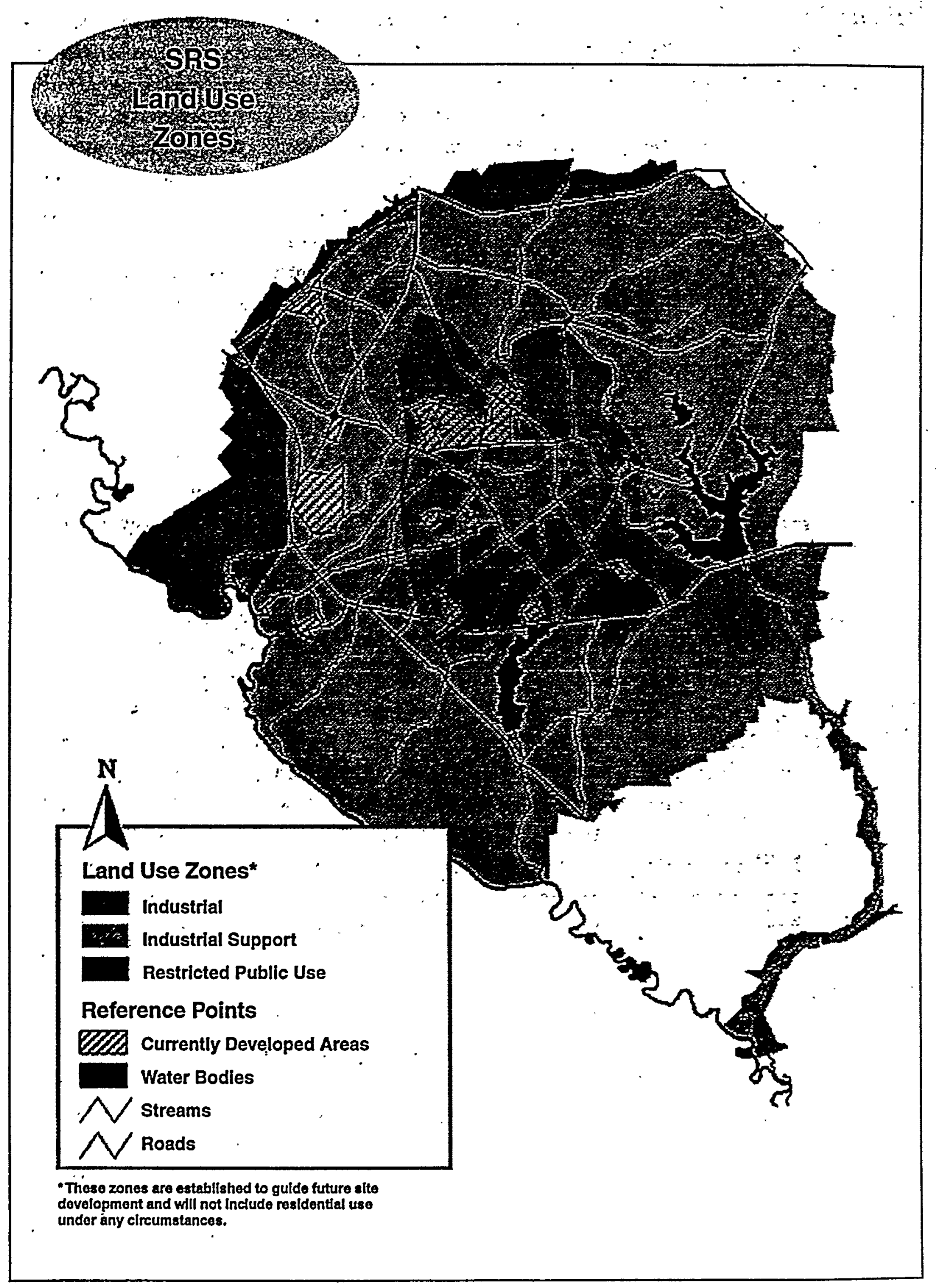




\section{zone one: industrial}

Principal activities and facilities in this zone include operations which may pose either a potentially significant nuclear or non-nuclear hazard to employees or the general public. Included are facilities that process, or store radioactive liquid or solid waste, fissionable materials, or tritium; conductseparations op erations; or conduct irradiated materials inspection fuel fabrication, decontamination or recovery opera tions. A brief description of the basic types of primary allowable activities in this zone follows.

Industrial-Heavy Non-Nuclear Heavy Industial is defined as a use engaged in the basic processing and manufacturing of materials or products predominately from extracted or raw materials, storage of, or mạnufacturing processes using flammable or explosive materials, or storage or manufacturing processes that in volve potentially hazardous or commonly recognized offensive conditions. These activities, because of their magnitude, or the magnitude of their effect or their cumulative effect on the surrounding area have an impact on the area. Such activities include those that could be potentially noxious, dangerous, or offensive to surrounding areas. These activities require as signifi-

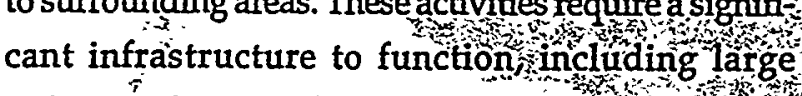
amounts of steam, electricity, process water, and ac cess to transportation and supporting safety organt zations. They also demand buffer zones (for âr Tre leases, receiving bodies for liquid effluents, noise and vibrationabatement, and odor and smoke dispersal); geotechnical suitability; low water table (to protect against releases); and available land for waste storage. As a general policy, unirelated activities should be 100 meters from the facility fence or unfenced facility-related operations. Because of the requirement for buffer zones and proximity to infrastructure, most industrial facilities will be located at the center of the site.

Industrial-Heavy Nuclear: This use has the same criteria as heavy industrial but also includes operations in which radioactive materials are used in such forms and quantity that a potential significant nuclear hazard exists to employees or the general public. Included are facilities that (1) produce, process, store and/or dispose of radioactive liquid or solid waste, fissionable materials, or tritium; (2) conduct separations operations; (3) conduct irradiated materials inspection, fuel fabrication, decontamination, or recovery operations; or (4) conduct fuel enrichment operations. Industrial-Light Industrial: Operations including predominately indoor industrial activities involving only those processes generating no significant particulates or gaseous emission that could create harmful or unpleasant effects outside the immediate area. These uses are engaged in the manufacture, predominantly from previously prepared mâterials, of finished prod: ucts or parts, including processing, fabrication, assembly, treattment, packaging storage, and distribution of such products but excluding basicindustrial processing. Examples of such operations include assembly, fabricating grinding,pinting, physical processing, or storage of previously manufactured components or previouisly prepared mâterials.

$$
\text { witis }
$$

Waste Facilities. Located in industrial areas, a

waste facility is any building, structure, installation, equipment including any pipe into a sewer treatment works, will, pit, pond, lagoon, impoundment, landfill, or any site or area where à hazardous substance has been deposited, stored, disposed of, placed or otherwise become located. Waste facilities do not include any consumer product in consumer use.

\section{zone two: industrial support}

The major activities in this zone would be much less impactive than those in the Industrial Zone. It is important to note that in this zone, as with all zones, specific development sites will be selected following the planning process described in the Introduction to this plan. This process incorporates the future use policies and considerations detailed in Section 4, such as utilizing developed sites rather than undeveloped sites 
whenever possible, and enhancing protection of ecologically sensitive areas such as Set-Asides and supporting threatened and endangered species. A brief description of primary allowable activities in this zone follows.

Administrative: Most activities in this area are related to support or service, either in general or specific function. They do not generate constant, large volumes of traffic, noise, or other harmful effects. Administrative areas serve as buffer and transitional zones between intensely developed and less developed areas. At SRS, the two major administrative categories are office parks (large tracts of land that have been planned, developed, and operated as integrated facilities for a number of separate office buildings and supporting ancillary uses with special attention given to circulation, parking, utility needs and compatibility); and laboratories (a building or group of buildings comprising facilities for scientific research, investigation, testing, or experimentation, but not facilities for the manufacture of products, except as incidental to the main purpose of the laboratory).

Research and Development: Research and Development areas are important for the acquisition and communication of knowledge of ecological and envi-. ronmental processes and principles considered useful in defining site program options and future decisions. Other research centers around the overall objectives of regulatory compliance support activities, monitoring programs for detection of environmental impact, baseline surveys for site characterization, measurement and modeling of transport processes, emergency response to unplanned effluent releases to the environment, and the development of information, tools, and techniques for environmental assessment, protection, and remediation.

Technology Development. These sites are used for field evaluation of innovative technologies in support of site missions and needs of the DOE Complex.
Resource Extraction: This category includes the utilization, development, and conservation of all minerals and exploration, extraction, processing, and disposal of materials such as clay, sand, gravel, and.rock.

Storage and Warehousing: This designation includes assorted storage and warehouse activities, including motor pools and vehicle maintenance activities.

Natural Resources Management:

- Fish and Wildlife Resources. Areas where management of animal populations takes place through the establishment, utilization, and maintenance of habitat or species enhancement project research and monitoring activities, or through taking (pursuing, hunting, fishing, trapping, or in any manner disturbing, capturing, killing, or attempting to take fish and game).

- Forest Resources. The utilization, development and conservation of all forest resources, including reforestation, forest management, harvest, processing, and disposal of timber. Also included are activities providing for the protection of forested land from fire and other .

$\because$ destructive agents.

- Conservation Areas. Environmentally sensitive and valuable.lands protected from any activity that would significantly alter their ecological integrity, balance, or character, except in cases of overriding public interest. These areas can include classes of plants and animals protected by the Endangered Species Act. These are classes of plants or animals that are designated by the Secretaries of Interior or Commerce as being in danger of extinction throughout all or a significant part of its range. 
zone three: restricted public use

Restricted Public uses include those that are determined to be safe to the public for limited activities. While still required as part of the safety and security buffer system, these areas are not presently required for operations, or waste disposal. The following is a brief description of primary allowable uses for this zone.

Recreation: Currently, most onsite recreation is in the form of hunting, although recent recreational additions include wellness facilities such as running tracks and walking trails. Now that the work focus is changing:and plant operations are downsizing, site officials are studying current hunting policies to ascertain what the future role of hunting should be at SRS. Specific recommendations for hunting programs include expansion of those alreädy in place ând initiation of hunting programs for turkey, waterfowl, quail, and other small game. Several large tracts in the Restricted Public Use Zone may be suitable for other low impact, controlled, outdoor public activities such as hiking, bird watching, camping, horseback riding, and bicycling.

Public Education: Cưrìnt èducational âctivities include Scout "Camporée" and numerous tours for offsite groups. The site is now in South Carolina's "Heritage Corridor," and various onsite and offsite groups are exploring different options for SRS participation in this program, using land in the Restricted Public Use Zone. 

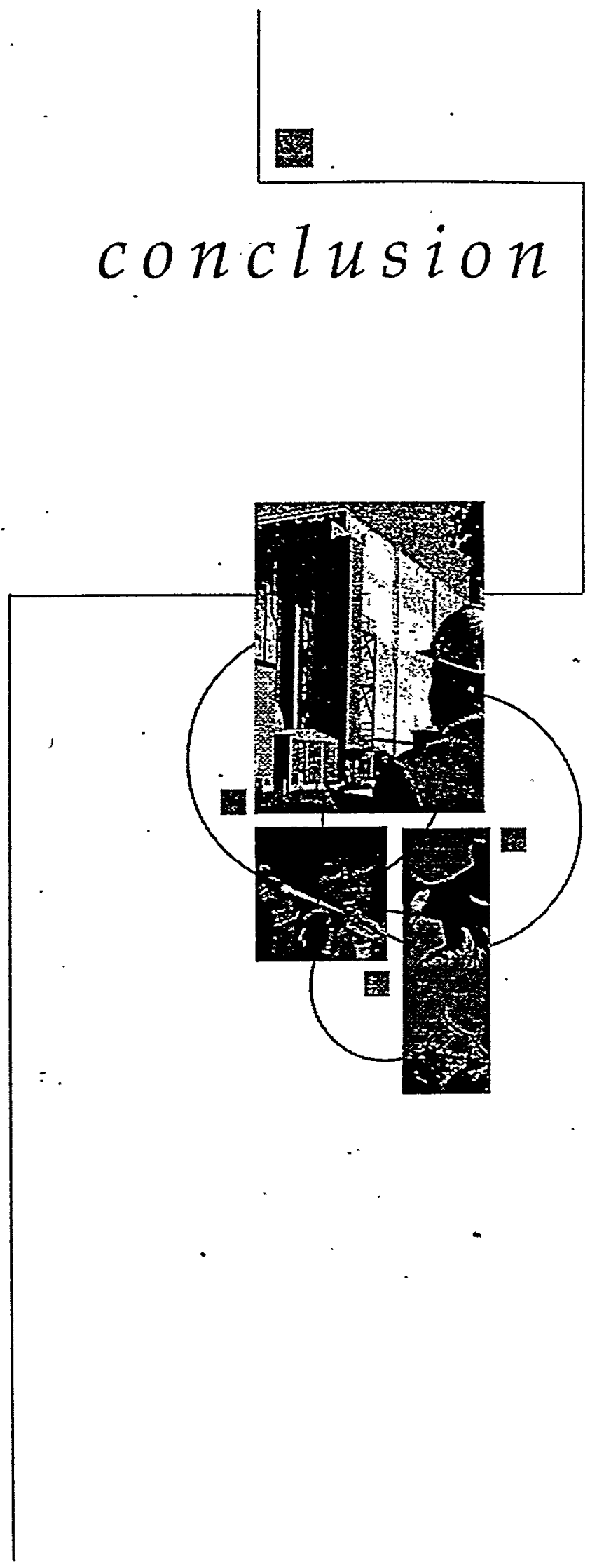
The Savannah River Site (SRS) Future Use Plan has presented a logical planning process designed to ensure that effective future-use decisions are made . over the next 50 years.

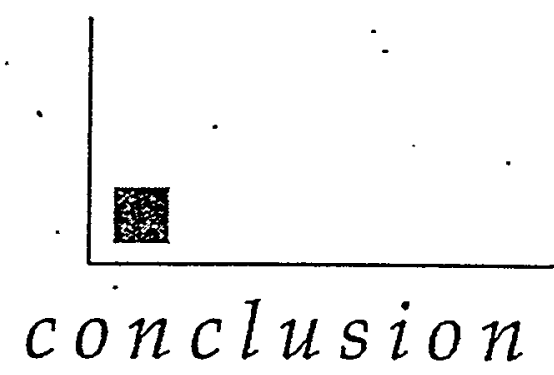

Sections 1 and 2 set the stage by describing the site and its region of influence. Section 3 outlined the site's current situation and summarized future mission and program requirements. The SRS futureuse policies, assumptions, and planning considerations were detailed in Section 4. Sections 5 and 6 addressed the analysis of four future-land use options and described how SRS will implement the Integral Site Model using the zoned planning con- cept.

To be successful, future-use planning must incorporate safety, health, and environmental considerations; ensure that current and future mission and program requirements are met; and include stakeholder input. We think this Future Use Plan has met those challenging criteria. By using the logical pro- cess and the zoned planning concept described in this plan, site management now has the tools to reach its goals into the next century. The planning process and zoned planning concept ensure that site policies are implemented, and all appropriate criteria are considered, yet still allow SRS to remain flexible and

For additional copies of this plan, contact Charles Borup by telephoning (803) 725-1579 or by e-mail

responsive to our nation's changing requirements. This systematic yet flexible process will help ensure that unique attributes of SRS - size, technical expertise, core competencies, National Environmental Research Park designation, and infrastructure continue to benefit the Department of Energy Complex and the best interests of the nation. Effective implementation of the Integral Site Model, using the zoned planning concept, will ensure that SRS remains a vital site in the future through concurrent, compatible land use, appropriate resource allocation, and a continuing focus on the safety, health, and protection of workers, the public and the environment.
at charles.borup@srs.gov. 

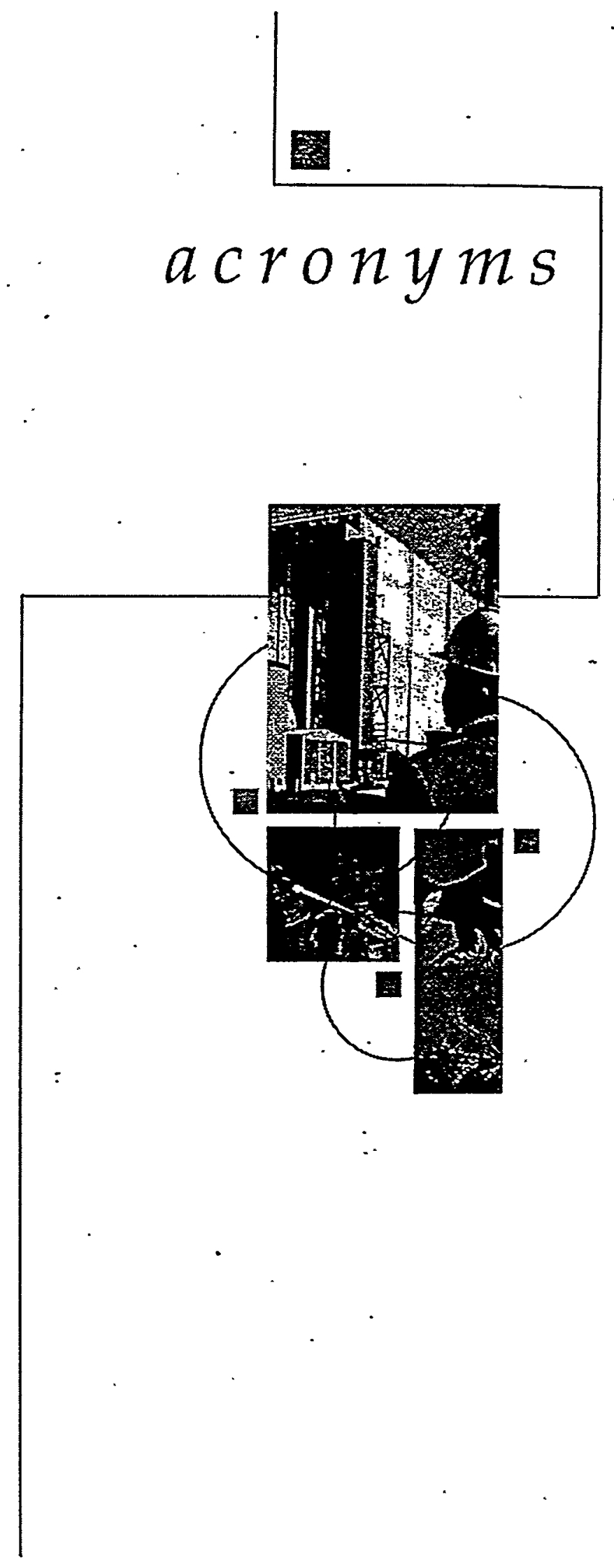


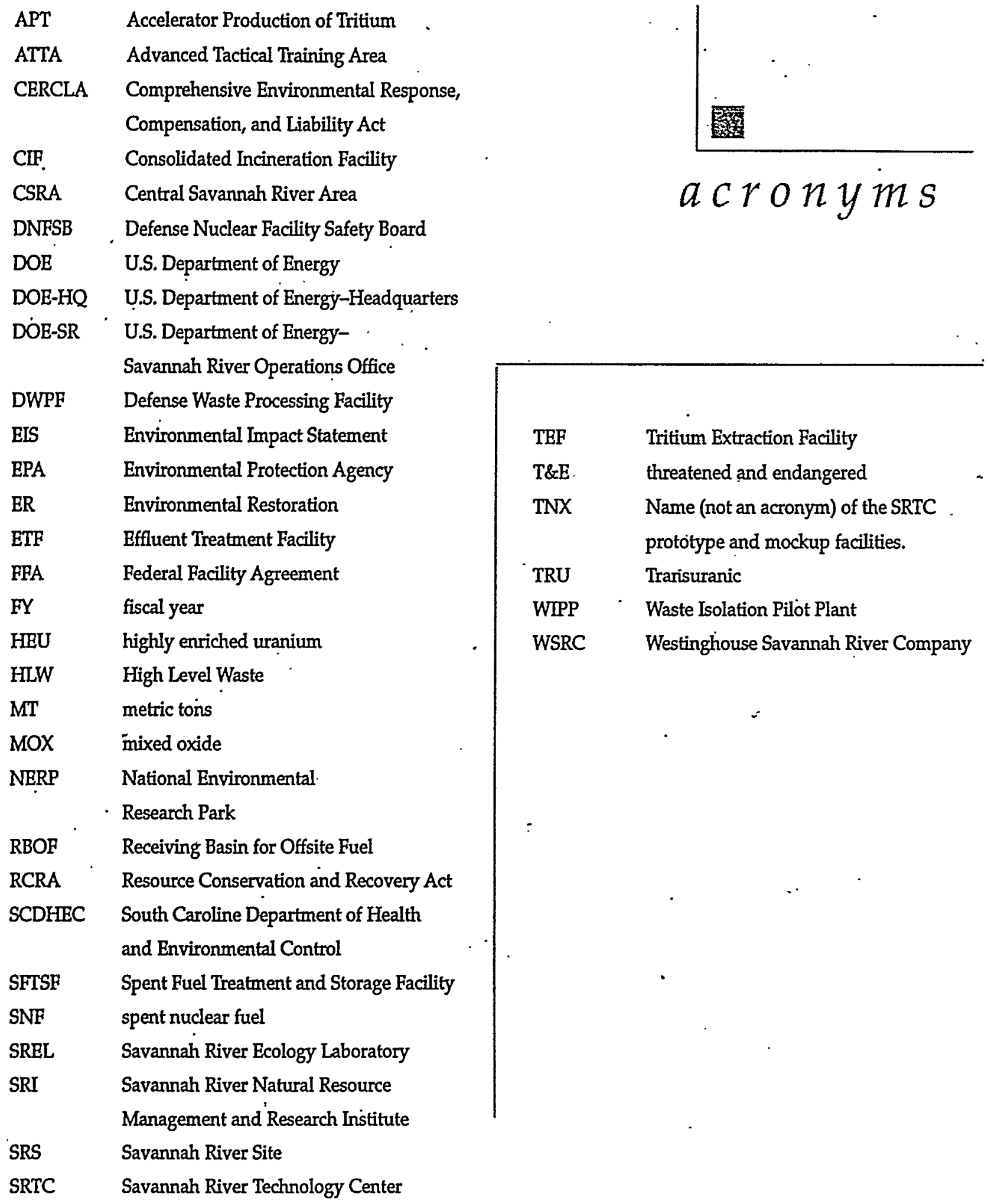

